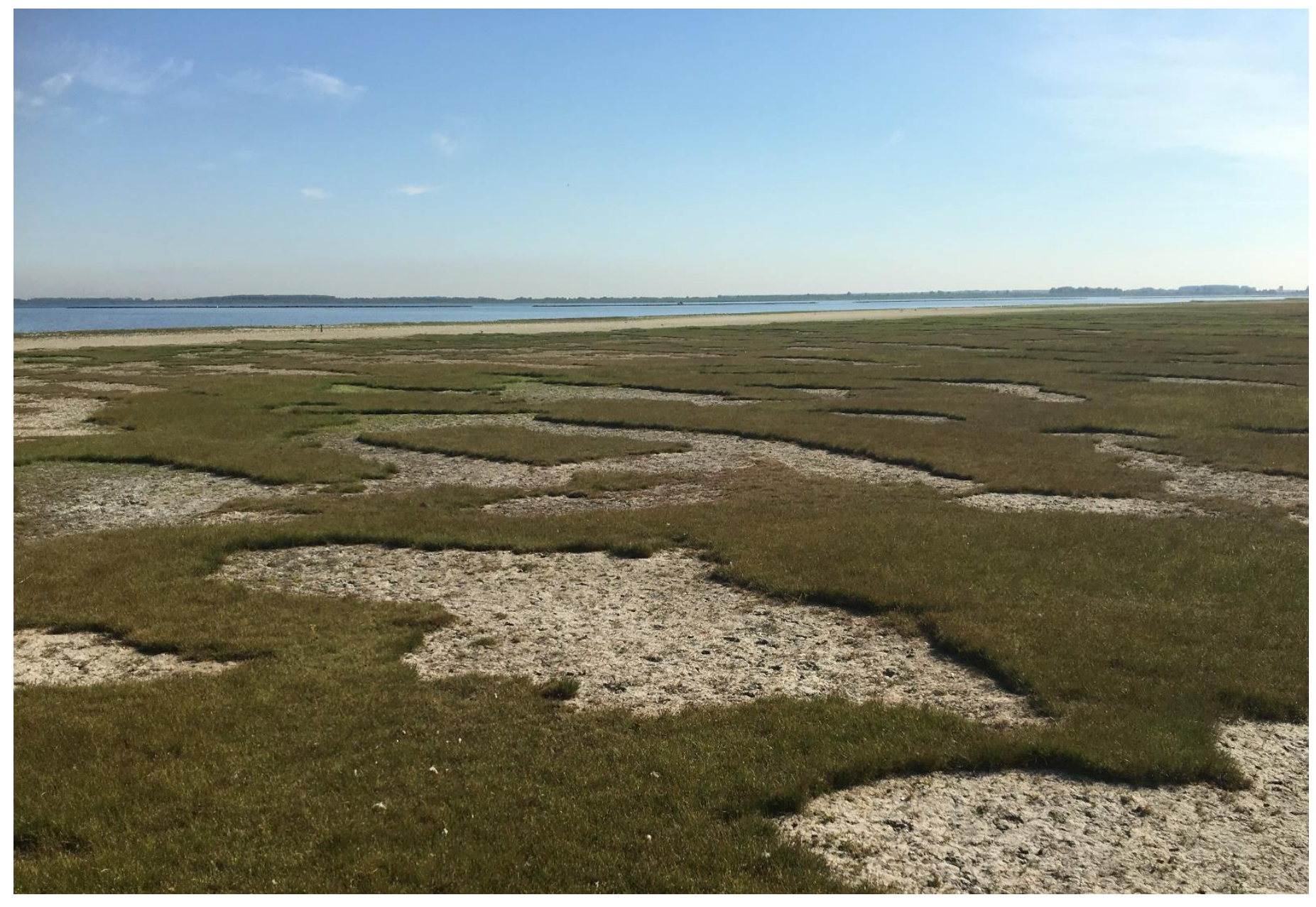

\title{
Scenariostudie natuurperspectief Grevelingenmeer
}

Auteurs Marijn Tangelder ${ }^{1}$, Jeroen Wijsman ${ }^{1}$, John Janssen ${ }^{2}$, Arno Nolte ${ }^{3}$, Brenda Walles ${ }^{1}$, Tom Ysebaert ${ }^{1}$

${ }^{1}=$ Wageningen Marine Research, ${ }^{2}=$ Wageningen Environmental Research, ${ }^{3}=$ Deltares
Wageningen University \&

Research rapport $\mathrm{C} 021 / 18$ 


\section{Scenariostudie natuurperspectief Grevelingenmeer}

Auteur(s): $\quad$ Marijn Tangelder ${ }^{1}$, Jeroen Wijsman ${ }^{1}$, John Janssen ${ }^{2}$, Arno Nolte ${ }^{3}$, Brenda Walles ${ }^{1}$, Tom Ysebaert $^{1}$

${ }^{1}=$ Wageningen Marine Research, ${ }^{2}=$ Wageningen Environmental Research,

$3=$ Deltares

Publicatiedatum: 1 augustus 2018

Dit onderzoek is uitgevoerd door Wageningen Marine Research in opdracht van en gefinancierd door het Ministerie van Landbouw Natuur en Voedselkwaliteit, in het kader van het Beleidsondersteunend onderzoekthema 'Natuurambitie Grote Wateren' (projectnummer BO-11-018.01-007) 
Tangelder M, Janssen J, Nolte A, Walles B, Wijsman J, Ysebaert T, 2018. Scenariostudie natuurperspectief Grevelingenmeer. Wageningen Marine Research Wageningen UR (University \& Research centre), Wageningen Marine Research rapportnummer C021/18, 164 blz.

Keywords: scenariostudie, gedempt getij, autonome ontwikkeling, natuurwaarden, Grevelingenmeer

Opdrachtgever: Ministerie van Landbouw, Natuur en Voedselkwaliteit

T.a.v.: Astrid Hilgers

Bezuidenhoutseweg 73

2594 AC Den Haag

BO-11-018.01-007

Dit rapport is gratis te downloaden van https://doi.org/10.18174/444734

Wageningen Marine Research verstrekt geen gedrukte exemplaren van rapporten.

Wageningen Marine Research Wageningen UR is ISO 9001:2008 gecertificeerd.

(C) 2016 Wageningen Marine Research Wageningen UR

Wageningen Marine Research, onderdeel van Stichting Wageningen Research KvK nr. 09098104,

IMARES BTW nr. NL 8113.83.696.B16

Code BIC/SWIFT address: RABONL2U IBAN code: NL 73 RABO 0373599285
De Directie van Wageningen Marine Research is niet aansprakelijk voor gevolgschade, noch voor schade welke voortvloeit uit toepassingen van de resultaten van werkzaamheden of andere gegevens verkregen van Wageningen Marine Research opdrachtgever vrijwaart Wageningen Marine Research van aanspraken van derden in verband met deze toepassing.

Dit rapport is vervaardigd op verzoek van de opdrachtgever hierboven aangegeven en is zijn eigendom. Niets uit dit rapport mag weergegeven en/of gepubliceerd worden, gefotokopieerd of op enige andere manier gebruikt worden zonder schriftelijke toestemming van de opdrachtgever. 


\section{INHOUD}

INHOUD

Samenvatting $\quad 5$

$1 \quad$ Inleiding $\quad 11$

1.1 Achtergrond 11

1.2 Aanleiding: waarom nog een natuurstudie? 11

1.3 Doel 12

1.4 Uitvoering 12

$\begin{array}{ll}1.5 & \text { Afbakening } \\ 1.6 & 12\end{array}$

1.6 Beperkingen 13

2 Werkwijze $\quad 14$

2.1 Formuleren scenario's en inhoudelijke speerpunten met betrokkenen 14

2.2 Ecologische onderbouwing: definiëren van ecotopen 15

2.3 Modelleren scenario's OD en 3D model 15

$\begin{array}{lll}2.4 & \text { Uitwerken ecotopenkaarten (GIS-analyse) } & 17\end{array}$

$\begin{array}{ll}\text { 2.4.1. Waterstanden } & 17\end{array}$

2.4.2. Dieptekaart 17

2.4.3. Ecotopenkaart $\quad 19$

$\begin{array}{lll}2.5 & \text { Beoordeling van de scenario's } & 22\end{array}$

$\begin{array}{ll}2.6 & \text { Effect op Natura } 2000 \text { habitattypes }\end{array}$

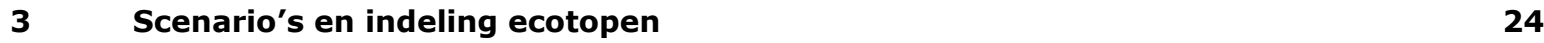

$\begin{array}{lll}3.1 & \text { Scenario's } & 24\end{array}$

$\begin{array}{ll}3.2 & \text { Indeling in ecotopen } \\ \end{array}$

Diep water $\quad 28$

$\begin{array}{ll}\text { Ondiep water } & 29\end{array}$

Intergetijdengebied $\quad 31$

$\begin{array}{ll}\text { Terrestrisch } & 33\end{array}$

$4 \quad$ Huidige situatie $\quad 35$

$\begin{array}{lll}4.1 & \text { Gebiedsbeschrijving } & 35\end{array}$

Waterhuishouding $\quad 35$

Bathymetrie en sedimentkarakteristieken $\quad 36$

$\begin{array}{ll}\text { Waterkwaliteit en zuurstofhuishouding } & 37\end{array}$

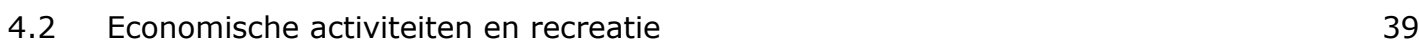

$\begin{array}{lll}4.3 & \text { Natuurwaarden } & 40\end{array}$

Belangrijke ecologische waarden in de Grevelingen $\quad 40$

$\begin{array}{ll}\text { Eilanden en oevers } & 40\end{array}$

$\begin{array}{ll}\text { Open water } & 43\end{array}$

$\begin{array}{lll}4.4 & \text { Natuurbeleid en -wetgeving } & 47\end{array}$

$5 \quad$ Ecotopenkaarten en uitkomsten modellering $\quad 48$

5.1 Resultaten van het 0D-model: Waterbalans 48

$\begin{array}{lll}5.2 & \text { Ecotopen per scenario } & 50\end{array}$

5.3 Verlies Natura 2000-habitat $\quad 52$

5.4 Resultaten van het 3D-model: effecten op zuurstofhuishouding en waterkwaliteit 54 
6.1 Autonome ontwikkeling natuurwaarden $\quad 58$

Eilanden en oevers $\quad 58$

Open water (watersysteem) $\quad 59$

6.2 Verandering van het watersysteem in een getijdesituatie $\quad 61$

$\begin{array}{ll}\text { De rol van slib in een getijdesituatie } & 61\end{array}$

$\begin{array}{ll}\text { Verwachting doorwerking in het voedselweb } & 61\end{array}$

6.3 Ontwikkeling van intergetijdengebieden $\quad 62$

Gedempt getij en zandhonger $\quad 62$

Betekenis intergetijdengebieden als foerageergebied $\quad 63$

Intergetijdengebied in relatie tot oevertypen $\quad 63$

$\begin{array}{ll}\text { Ontwikkeling van schor ecotoop } & 64\end{array}$

Ecologische betekenis zomer- en winterintergetijdengebied 65

6.4 Natuurwaarden eilanden en oevers in een getijdensituatie en mitigatiemogelijkheden 66

$\begin{array}{ll}\text { Broedvogels } & 70\end{array}$

Zoogdieren: de noordse woelmuis $\quad 71$

$\begin{array}{lll}6.5 & \text { Relatie met omliggende gebieden } & 71\end{array}$

$7 \quad$ Optimalisatie waterbeheer

7.1 Mogelijkheden en beperkingen van het nieuwe doorlaatmiddel 72

$\begin{array}{lll}7.2 & \text { Verkennen opties voor optimalisatie waterbeheer voor natuurwaarden } & 74\end{array}$ $\begin{array}{ll}\text { Sturen van getij ten bate van foeragerende vogels } & 74\end{array}$

$\begin{array}{ll}\text { Peilbeheer ten bate van broedvogels en vegetatie } & 74\end{array}$

8 Conclusies, discussie, aanbevelingen en kennisvragen $\quad 75$

8.1 Ontwikkeling Grevelingenmeer na afsluiting en verwachte autonome ontwikkeling 75

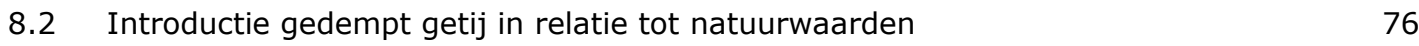

$\begin{array}{lll}8.3 & \text { Terrestrische natuurwaarden versus natuurwaarden van open water } & 79\end{array}$

$\begin{array}{lll}8.4 & \text { Optimalisatie natuurwaarden door een aangepast waterbeheer } & 80\end{array}$

$\begin{array}{lll}8.5 & \text { Onzekerheden en beperkingen van dit onderzoek } & 80\end{array}$

\begin{tabular}{ll}
8.6 & Aanbevelingen voor vervolgstudies \\
\hline
\end{tabular}

\begin{tabular}{ll}
8.7 & Kennislacunes en kennisvragen \\
\hline
\end{tabular}

$\begin{array}{lr}\text { Dankwoord } & 84\end{array}$

$\begin{array}{lr}\text { Kwaliteitsborging } & 85\end{array}$

$\begin{array}{lr}\text { Literatuur } & 86\end{array}$

$\begin{array}{lr}\text { Bijlagen } & 90\end{array}$

A. Verslag overleg met Coalitie Delta Natuur $\quad 91$

B. Verslag overleg met Natuur en Vogelwacht Schouwen-Duiveland 93

C. Verslag verdiepingsworkshop met natuurpartijen en beheerders $\quad 94$

D. Verslag overleg tussentijdse terugmelding met natuurpartijen en beheerders 99

E. Beschrijving OD en 3D model $\quad 104$

F. Berekende waterstanden $\quad 107$

G. Verslagen expertsessies $\quad 113$

H. Aantekeningen interview experts Bureau Waardenburg $\quad 126$

I. Doelstellingen Natura 2000 Grevelingenmeer $\quad 129$

J. Doelen van de Kaderrichtlijn Water $\quad 131$

K. Ecotopenkaarten volledige gebied $\quad 132$

L. Ecotopenkaarten Hompelvoet $\quad 135$

M. Ecotopenkaarten Veermansplaat $\quad 138$

N. Effect op habitattypen H1310A en H2190B 141

O. Gemeten oeverprofielen (RWS data) vs geïnterpoleerde oeverprofielen (deze studie)153 


\section{Samenvatting}

Als gevolg van de beperkte wateruitwisseling in het Grevelingenmeer treden er tijdens de zomerperiode regelmatig zuurstofarme condities op in de geulen en diepere delen van het meer. Deze zuurstofarme condities hebben gevolgen voor de bodemdiergemeenschappen en via de voedselketen mogelijk ook voor kreeftachtigen, vissen en vogels. In de Rijksstructuurvisie (RSV) Grevelingen en VolkerakZoommeer zijn diverse oplossingsrichtingen verkend om de waterkwaliteit te verbeteren als voorbereiding op een Rijksbesluit. In 2014 heeft het kabinet de ontwerp-RSV vastgesteld waarin het ontwikkelperspectief wordt geschetst voor een Grevelingenmeer met gedempt getij van $50 \mathrm{~cm}$ via een extra doorlaat in de Brouwersdam. In de planvorming is voor het Grevelingenmeer gekeken naar kansen vanuit verschillende invalshoeken zoals waterkwaliteit, getijdenenergie en waterveiligheid. Natuurorganisaties waren van mening dat hierbij vooral aandacht is geweest voor effecten op huidige beschermde natuurwaarden (in relatie tot Natura 2000-wetgeving), maar dat er slechts beperkte aandacht is geweest voor kansen voor het verzilveren van nieuwe (estuariene) natuurwaarden en optimalisatie mogelijkheden van toekomstig waterbeheer ten bate van natuurwaarden in een situatie met gedempt getij. In de afrondende fase van onderhavige studie (maart 2018) heeft het kabinet aangekondigd dat 75 miljoen euro extra vrij zal worden gemaakt voor de realisatie van een doorlaat in de Brouwersdam en is de voorbereiding van de planuitwerking gestart.

Het ministerie van Landbouw, Natuur en Voedselkwaliteit (LNV) vindt het van belang dat het perspectief en de kansen voor natuur in het Grevelingenmeer grondiger worden uitgediept met betrokkenheid van verschillende experts en dat natuurpartijen (lokaal en landelijk), beheerders (Staatsbosbeheer en RWS) en provincies hierbij worden betrokken. Daarom heeft zij Wageningen Marine Research gevraagd om dit nader te onderzoeken. Er is aangesloten op het voorkeursalternatief van de RSV (50 cm getij), maar daarnaast zijn ook breder de gevolgen voor de natuur van (1) een kleinere getijslag en (2) een aangepast peilbeheer onderzocht en er is een doorkijk gegeven naar de lange termijn gevolgen waarbij tevens het effect van zeespiegelstijging is meegenomen. In samenspraak met de betrokken partijen en de opdrachtgever zijn vijf scenario's gedefinieerd die in voorliggende studie nader zijn onderzocht:

Scenario 0: Huidige situatie (Geen getij maar wel peilbeheer met een waterstand van -0,20m NAP, in broedseizoen (apr-jul) $6 \mathrm{~cm}$ verlaging naar -0,26 NAP, in periode sep-feb 3 perioden van 3 weken middenpeil NAP $-0,16 \mathrm{~m}$.

Scenario 1: RSV (50 cm getij);

Scenario 2: RSV Springtij (50 cm getij $+/-5 \mathrm{~cm}$ springtij/doodtij);

Scenario 3: Getij30 (30 cm getij);

Scenario 4: RSV-Peilbeheer (50 cm getij, middenstand winter +0,10 m NAP, zomer -0.26 m NAP);

Scenario 5: RSV-Zeespiegelstijging ( $50 \mathrm{~cm}$ getij en $40 \mathrm{~cm}$ (KNMI $W_{H}$ klimaatscenario voor 2050) verhoging van de middenstand).

In uitvoering van deze scenariostudie is het voorkeursalternatief (scenario 1) van de ontwerp-RSV met $50 \mathrm{~cm}$ getijslag via een doorlaat in het noordelijk deel van de Brouwersdam als basis gehanteerd. Het effect van variatie in getijslag, peilbeheer en zeespiegelstijging is vervolgens in de verschillende aanvullende scenario's (2, 3, 4 en 5) onderzocht waarbij de gevolgen voor de natuurwaarden zijn ingeschat. Om een beeld te kunnen geven van de te verwachten natuurtypen voor ieder scenario is ervoor gekozen om de effecten te kwantificeren op basis van ecotopen. De focus van deze studie lag daarbij op de veranderingen vanuit een systeemperspectief en niet op toetsing van beschermde natuurwaarden aan Natura 2000-wetgeving. Wel zijn, omdat dit een wens was vanuit de betrokkenen, potentiële effecten van veranderingen in waterbeheer in de scenario's op de Natura 2000-habitattypen H1310A (Zilte pionierbegroeiingen - zeekraal) en H2190B (Vochtige duinvalleien - kalkrijk) ingeschat en bediscussieerd.

De doelen van deze studie waren:

a. Het kwantitatief beschrijven van de verwachte veranderingen van potentiële ecotopen in verschillende scenario's van waterbeheer met gedempt getij in het Grevelingenmeer; 
b. Het kwalitatief beschrijven van de potentiële ontwikkeling van natuurwaarden met focus op de in samenspraak met de opdrachtgever en betrokkenen aangegeven speerpunten; en

c. Aangeven van mogelijke kansen voor optimalisatie van waterbeheer (mitigerende / compenserende maatregelen) ten bate van specifieke (of gewenste) natuurwaarden.

Deze doelen zijn onderzocht met behulp van 0D- en 3D-modellen voor ieder scenario om inzicht te krijgen in waterbalans, waterstanden, doorzicht, primaire productie en zuurstofconcentratie. Op basis van de modeluitkomsten en gebruikmakend van een gecombineerde hoogte- (AHN voor het terrestrische deel) en dieptekaart (vaklodingen voor het sublitorale deel) zijn per scenario de arealen van de onderscheiden ecotopen bepaald en zijn ecotopenkaarten per scenario uitgewerkt.

De kwaliteit van natuurwaarden en kansen voor optimalisatie zijn bediscussieerd aan de hand van bestaande literatuur en met hulp van workshops met experts van diverse kennisinstellingen en experts met lokale (terrein)kennis. Daarnaast wordt ingegaan op de beperkingen van deze studie, en worden aanbevelingen voor vervolgstudies en kennislacunes en kennisvragen geformuleerd.

\section{Verwachte verandering in ecotopen}

De arealen van de ecotopen in de verschillende scenario's zijn berekend aan de hand van gemodelleerde waterstanden en de gecombineerde hoogte/diepte kaart van het Grevelingenmeer. Een beperking van dit onderzoek is de onzekerheid van het verloop van het hoogteprofiel van de ondiepe oevers tussen 0,20 en ca $-1,50$ m NAP omdat hier diepte gegevens ontbreken. De diepte in deze zone is berekend door interpolatie. De invloed van zout op de terrestrische ecotopen is afgeleid van de zoutindringing in de huidige situatie welke is ingeschat aan de hand van het hoogteprofiel van de huidige zilte graslanden. De arealen van met name de ecotopen terrestrisch zoet, terrestrisch met zoutinvloed, intergetijdengebied en ondiep water moeten daarom als een globale schatting beschouwd worden.

De ecotopenanalyse laat zien dat er in de huidige situatie een gebied van ruim 300 ha is dat in de zomermaanden droogvalt als gevolg van het huidige peilbeheer. Deze droogvallende zone draagt bij aan geschikt broedgebied voor (grondbroedende) kustbroedvogels. Het RSV scenario met $50 \mathrm{~cm}$ getij leidt tot een groter areaal potentieel intergetijdengebied (zo'n 1100 ha) dan scenario Getij30 (zo'n 800 ha). Dit intergetijdengebied komt in de plaats van het ondiep water en het ecotoop zomer droog. Ook terrestrisch ecotoop gaat verloren in deze scenario's. Het ecotoop terrestrisch met zoutinvloed schuift op naar hogere delen van de oevers en de eilanden. Het totaal areaal aan ecotoop terrestrisch met zoutinvloed neemt in beide scenario's wat in omvang toe en schuift in de hoogte op ten koste van het terrestrisch zoet ecotoop (respectievelijk zo'n 400 en 300 ha afname). Het scenario RSV Springtij is vergelijkbaar met het scenario RSV, alleen ontstaat hier een klein areaal aan potentieel schor ecotoop door de springtij/doodtij cyclus (zo'n 30 ha).

In scenario RSV-Peilbeheer ontstaat het grootste areaal intergetijdengebied (zo'n 1700 ha). Hiervan is slechts een klein deel permanent intergetijdengebied, terwijl grote delen dan wel gedurende de zomer permanent droog vallen ("winter intergetijdengebied") of permanent onder water staan tijdens de winter ("zomer intergetijdengebied"). In dit scenario neemt het ecotoop terrestrisch zoet fors af (zo'n 850 ha verlies), terwijl het ecotoop terrestrisch met zoutinvloed wat toeneemt, vergelijkbaar met de andere scenario's. Dit is niet onlogisch gezien de inschatting van het areaal van dit ecotoop gebaseerd is op de zoutinvloed op basis van de huidige verspreiding van zilte vegetaties en in de ecotopen analyse mee opschuift naar boven toe (deels ten koste van terrestrisch zoet). In het scenario met zeespiegelstijging (RSV-zeespiegelstijging) neemt het areaal sublitoraal (ondiep en diep water ecotoop) toe met zo'n 450 ha ten opzichte van de huidige situatie. Het areaal permanent intergetijdengebied wordt kleiner (zo'n 700 ha) dan in het RSV scenario, en ook het ecotoop terrestrisch zoet neemt fors af (zo'n 950 ha). 


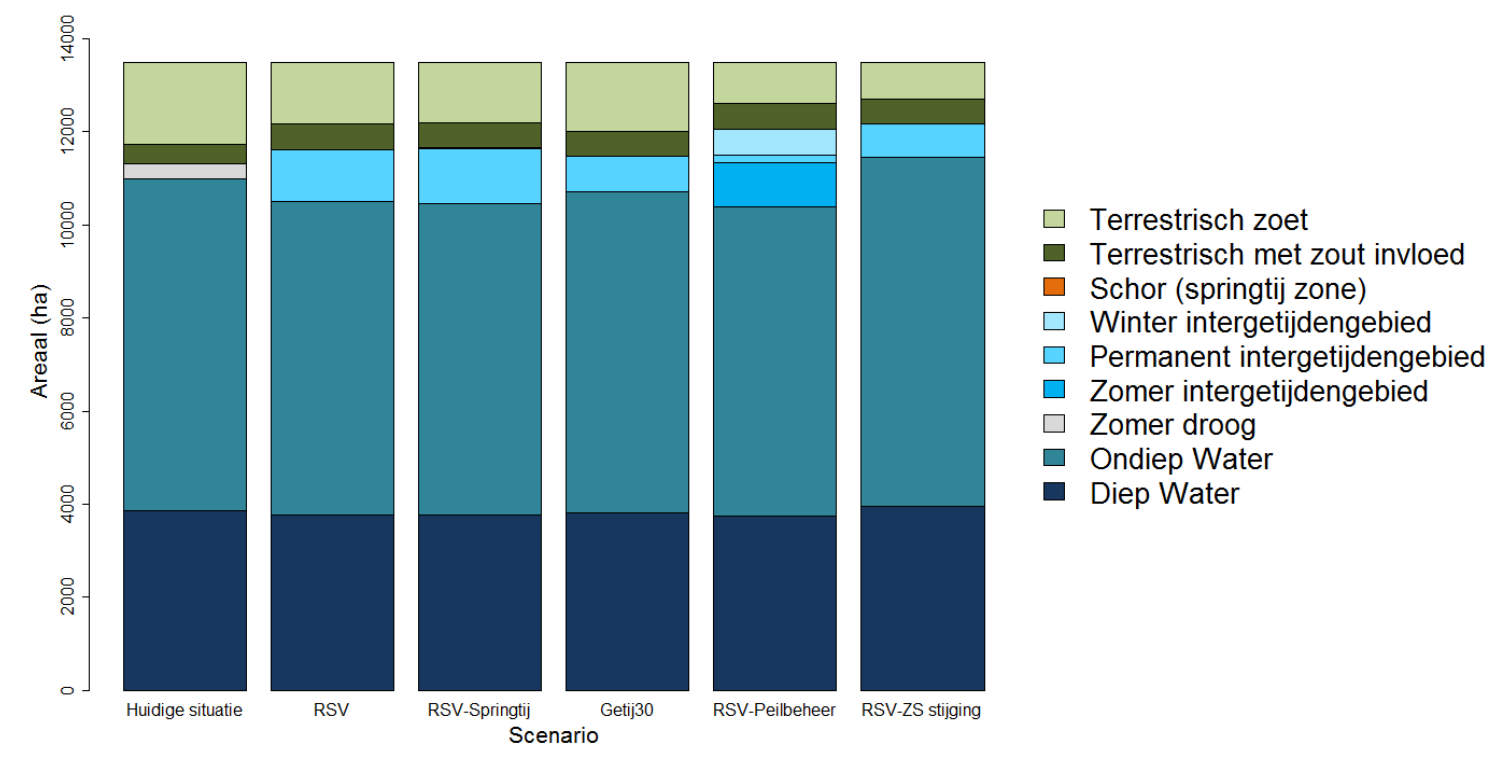

Arealen (ha) van de verschillende ecotopen voor de verschillende scenario's.

\section{Ontwikkeling van natuurwaarden}

De ontwikkeling van natuurwaarden in de scenario's, inclusief de Natura 2000 habitattypes Zilte pionierbegroeiingen met zeekraal (H1130A) en Vochtige duinvalleivegetaties - kalkrijk (H2190B), is ingeschat met behulp van expertoordeel. De focus lag daarbij op de in deze studie gedefinieerde speerpunten, vooral gericht op enerzijds de autonome ontwikkeling van de vegetatie op de eilanden en oevers en kansen/effecten voor kustbroedvogels en anderzijds de autonome ontwikkeling van natuurwaarden onderwater en de gevolgen van veranderingen in het watersysteem in een situatie met gedempt getij (zoals doorzicht, primaire productie en zuurstofconcentratie).

\section{Vegetatie en broedgebieden}

Introductie van getij zal ervoor zorgen dat zilte vegetaties en laaggelegen vochtige duinvalleivegetaties regelmatig overspoelen. Zilte vegetaties kunnen op een aantal plekken opschuiven naar hoger gelegen delen, namelijk daar waar een flauw aflopende oever aanwezig is en ze niet beperkt worden door aanwezigheid van struweel en ruigten. Dit gaat ten koste van vochtige duinvalleivegetaties. De vochtige duinvalleivegetaties zullen naar verwachting niet of maar zeer beperkt kunnen opschuiven naar hoger gelegen delen omdat daar geen plek is door aanwezigheid van struweel, stuifruggen, oude schorranden, ruigten etc. Ook ontbreken op de hoger gelegen delen vaak de juiste omstandigheden (door verzuring, bodemvorming en het ontbreken van kalkrijke kwel) voor het opschuiven van vochtige duinvallei vegetaties.

In deze studie is vervolgens nader gekeken naar de ontwikkeling van de Natura 2000 habitattypes Zilte pionierbegroeiingen met zeekraal (H1130A) en Vochtige duinvalleivegetaties - kalkrijk (H2190B). Het habitattype Zilte pionier begroeiingen met zeekraal (H1310A) zal in scenario's met $50 \mathrm{~cm}$ getij voor > $90 \%$ overspoelen. In scenario Getij30 bedraagt deze overspoeling $>80 \%$. Deze waarden zijn gebaseerd op de twee beschikbare, deels verouderde en nog niet goedgekeurde Natura2000 habitatkaarten. Op basis van expert oordeel is de verwachting dat dit habitattype deels kan opschuiven naar hoger gelegen delen, maar netto wel in areaal zal afnemen. Peilbeheer kan wel een gunstige invloed hebben op het areaal omdat het dan in de zomermaanden kan uitbreiden. Het habitattype Vochtige duinvalleivegetaties - kalkrijk (H2190B) zal in de scenario's met $50 \mathrm{~cm}$ getij voor minimaal $11 \%$ overspoelen en minimaal $6 \%$ in het Getij30 scenario. Op basis van expertoordeel is ingeschat hoe dit habitattype zich in een getijdensituatie gaat ontwikkelen. De verwachting is dat de afname groter zal zijn dan enkel het direct verlies door overspoeling, omdat ook de niet direct overspoelde oppervlakte van dit habitattype te maken zal krijgen met zoutspray en incidentele overstroming bij stormen, en een mogelijk veranderde zoetwaterbel. Naar verwachting zal het habitattype 'Vochtige duinvalleivegetaties - kalkrijk' in het Getij30 scenario voor 10-30 \% verdwijnen en in de RSV scenario's minimaal voor 40-60\% verdwijnen en gaat naar verwachting de populatie groenknolorchis grotendeels verloren. Dit areaal is groter dan eerdere schattingen in de aanvullende natuureffecten studie (RoyalHaskoningDHV, 2017). In voorliggende studie wordt een hoger verlies ingeschat bij alle scenario's, omdat laag in de zonering 
(waar de hoogste directe en indirecte verliezen optreden) inmiddels brakke en zilte graslanden op de door RoyalHaskoning DHV (2017) gebruikte vegetatiekaarten uit 2001/2005 door successie tot duinvalleibegroeiingen zijn ontwikkeld (gebaseerd op informatie van gebiedsdeskundigen/experts en inventarisaties van de Kraker in 2016).

Huidige broedgebieden voor kustbroedvogels bevinden zich op de laaggelegen, weinig tot laag begroeide delen van o.a. Slikken van Bommenede, Markenje en de Slikken van Flakkee. Het huidige peilbeheer met een lager middenpeil in het broedseizoen zorgt ervoor dat tijdens deze periode een groter oppervlak aan schaars en onbegroeid terrein aanwezig is. Zonder dit peilbeheer zouden er minder kustbroedvogels kunnen broeden in het Grevelingenmeer. Bij het invoeren van gedempt getij (met een vast middenpeil) zullen deze gebieden overspoelen en zal de functie als broedgebied grotendeels verloren gaan. De verwachting is dan ook dat het aantal broedparen zal afnemen. Een kwetsbaar punt is het verlies van de kale zones door getijoverspoeling welke van belang zijn voor solitair broedende vogels zoals de strandplevier. Ook bij de invoering van $30 \mathrm{~cm}$ getij zullen deze laaggelegen broedgebieden voor kustbroedvogels verdwijnen. Het voeren van peilbeheer met een lager peil in de zomer dan in de winter, zoals in scenario 4 'RSV-Peilbeheer', is gunstig voor het ontstaan van kale delen om te broeden, vergelijkbaar met het zomer droog ecotoop in de huidige situatie.

Overigens is tevens de verwachting dat het leefgebied van de noordse woelmuis af zal nemen omdat deze soort vooral voorkomt op de laaggelegen delen met grasruigte die door het getij veranderen in intergetijdengebied.

\section{Zuurstofgehalte, algen, zoöplankton en bodemdieren}

In de huidige situatie zijn grote delen van de diepe geulen en diepe putten langdurig zuurstofarm. Volgens modelanalyses betreft dit zo'n 1640 ha (met meer dan 7 dagen aaneengesloten een zuurstofconcentratie van minder dan $3 \mathrm{mg} / \mathrm{l}$ ). Modelanalyse wijst uit dat een relatief beperkt getij van $30 \mathrm{~cm}$ al een aanzienlijke verbetering van de waterkwaliteit oplevert en het zuurstofarme areaal afneemt tot 870 ha, maar nog wel aanwezig is. Met $50 \mathrm{~cm}$ getij neemt het zuurstofarme areaal nog verder af (tot $580 \mathrm{ha}$ ) en is het areaal beperkt tot de diepe putten. Eerder is aangetoond dat tussen $40 \mathrm{~cm}$ en 60 $\mathrm{cm}$ getij er afvlakking optreedt, hetgeen erop duidt dat een verdere toename van de getijslag nog maar in een beperkte verbetering resulteert. Bij zeespiegelstijging neemt het zuurstofarme areaal iets toe, vermoedelijk omdat de waterdiepte in het meer toeneemt. Op basis van de beschikbare kennis gebaseerd op modelberekeningen is niet met zekerheid aan te geven hoeveel getij er nodig is om ervoor te zorgen dat in alle jaren (d.w.z. onder alle meteorologische condities) aan het streefbeeld (max. 5\% zuurstofarm areaal) wordt voldaan. In sommige jaren met veel wind en lage zomertemperaturen zou $25 \mathrm{~cm}$ getij genoeg kunnen zijn, terwijl in andere jaren met weinig wind en hoge zomertemperaturen minimaal $50 \mathrm{~cm}$ getij nodig is. Daarom wordt door experts $50 \mathrm{~cm}$ getij aangehouden om het risico op het niet halen van het streefbeeld klein te houden.

Primaire productie in het Grevelingenmeer is in de huidige situatie stikstof-gelimiteerd in het late voorjaar en de zomer (mei-augustus). In het vroege voorjaar (april) kan korte tijd fosfaat-limitatie voorkomen. Door de uitwisseling met de Voordelta komt meer stikstof beschikbaar voor algengroei en het invoeren van een gedempt getij zal volgens de modelberekeningen dan ook leiden tot een relatief grote toename in de primaire productie. Het verschil tussen de scenario's met een gedempt getij is niet zo groot. De algen vormen het laagste trofische niveau in het voedselweb en vormen voedsel voor allerlei soorten zoals de kleine in het water zwevende organismen, het zoöplankton, en voor in en op de bodem levende dieren, het macrozoöbenthos, in het bijzonder (filtrerende) schelpdieren zoals mosselen, oesters en kokkels. Het zoöplankton vormt een belangrijke voedselbron voor allerlei (pelagische) vissoorten, terwijl de bodemdieren dan weer een voedselbron vormen voor vissen en vogels. De verwachting is dat de toename in algen voornamelijk ten goede komt aan filtrerende schelpdieren (ten koste van het zoöplankton) door toename van primaire productie en waterbeweging en daarnaast toename van areaal aan leefgebied voor schelpdieren door het kleiner worden van het zuurstofarme areaal.

\section{Vissen en vogels}

Over de verwachte veranderingen in visstand zijn experts niet helemaal eensgezinds. Enerzijds is de verwachting dat zoöplankton mogelijk afneemt, als gevolg van concurrentie om de algen, door een toename van de benthische filtrerende gemeenschappen (met name schelpdieren). Anderzijds zullen door het vergroten van de connectiviteit met de Noordzee meer mariene vissoorten het Grevelingenmeer in- en uitzwemmen. Ook zal de invoering van gedempt getij naar verwachting gunstig zijn voor 
bodemvissen door opheffen van de zuurstofdepletie. Uiteraard hangt de verwachte ontwikkeling van visetende vogels sterk samen met de visstand en is het onzeker hoe aantallen zich precies gaan ontwikkelen. Een eventuele toename van pelagische vissen in het Grevelingenmeer zou gunstig zijn als voedsel voor broedvogels als de grote stern, dwergstern en visdief. Een toename in bodemvissen is gunstig voor soorten als fuut, geoorde fuut, kleine zilverreiger en lepelaar. De verwachting is dat er bij gedempt getij van $30-50 \mathrm{~cm}$ intergetijdengebieden ontwikkelen die, hoewel relatief beperkt van omvang in vergelijking met een volwaardige getijslag, waardevol zijn als foerageergebied voor vogels zoals steltlopers. De intergetijdengebieden zullen naar verwachting een laag-dynamisch karakter kennen, waar zich een rijk bodemleven kan ontwikkelen dat vergelijkbaar is met de Oosterschelde. De bestaande vegetatie die zal overspoelen bij introductie van gedempt getij zal (geleidelijk) afsterven en kan mogelijk de vestiging en ontwikkeling van bodemfauna hinderen of vertragen. Om als geschikt foerageergebied te kunnen fungeren zijn ook andere factoren zoals overspoelingsduur van belang.

\section{Kansen voor optimalisatie van waterbeheer}

De waterstand in het Grevelingenmeer is gereguleerd en dat zal met het nieuwe doorlaatmiddel in de Brouwersdam ook zo zijn. Voor die sturing zijn in theorie meerdere knoppen beschikbaar bestaande uit a. de huidige Brouwerssluis, b. de Flakkeese spuisluis, en de c. 15 kokers van het referentieontwerp van het nieuwe doorlaatmiddel in de Brouwersdam. Door het lagere middenpeil van het Grevelingenmeer is de tijdsduur dat de waterstand in de Voordelta lager is dan in het Grevelingenmeer korter dan de tijdsduur dat de waterstand in de Voordelta hoger is dan in het Grevelingenmeer. Daarom is de zogenoemde 'ebfase' waarin afwatering naar de Voordelta plaatsvindt sturend voor het ontwerp van het doorlaatmiddel. Voor de 'vloedfase' is er sprake van overdimensionering en dit biedt ruimte voor optimalisatie van de getijkromme. Om de capaciteit ook tijdens een seizoensgebonden verlaging van bijvoorbeeld $6 \mathrm{~cm}$ zoals in het huidige peilbeheer in alle gevallen te handhaven zou een extra $\left(16^{\mathrm{e}}\right)$ koker nodig zijn. Ook zal zeespiegelstijging op termijn (vanaf $30 \mathrm{~cm}$ ) vragen om aanpassing van het waterbeheer of het doorlaatmiddel. Met experts is bediscussieerd hoe bepaalde sturing van het doorlaatmiddel gunstig zou kunnen zijn voor natuurwaarden. Hier kwamen de volgende drie punten uit naar voren: 1 . instelling van een "asynchroon getij" waarbij het getij op het Grevelingenmeer enkele uren achterloopt biedt mogelijk meerwaarde voor overtijende steltlopers (verlenging van de foerageertijd), 2. vloeddominant getij met een lange ebfase (snel op, langzaam af) biedt voordelen voor foeragerende vogels omdat bodemdieren in een dun laagje water vaak nog actief en relatief makkelijker te vangen zijn, 3. peilbeheer met een lager zomerpeil en een hoger winterpeil is gunstig voor het creëren van kale zones ten bate van kustbroedvogels van kale gronden en voor de uitbreiding van zilte vegetaties.

Voorliggende studie heeft ook een aantal beperkingen die met nader onderzoek zouden kunnen verkleind worden. Een belangrijke beperking van dit onderzoek is de onzekerheid van het verloop van het hoogteprofiel van de ondiepe oevers tussen $-0,20$ en $-1,50 \mathrm{~m}$ NAP. Een gedetailleerde (bathymetrie)opname van deze zone is dan ook noodzakelijk en in vervolgonderzoek kunnen dan de veranderingen in arealen met meer nauwkeurigheid worden berekend. Naast meer nauwkeurige diepte gegevens zouden dan ook geactualiseerde hoogte gegevens kunnen worden gebruikt van het Grevelingemeer die in 2014 beschikbaar zijn gekomen (AHN3). Tevens is er op korte termijn behoefte aan één geactualiseerde, vlakdekkende Natura2000 habitatkaart die gebaseerd is op recente inventarisaties en die is goedgekeurd door het ministerie van Landbouw, Natuur en Innovatie. Momenteel circuleren er twee verschillende kaarten die op verschillende, deels verouderde, gegevens zijn gebaseerd en dit maakt het inschatten van effecten en vergelijken met andere studies erg lastig. Deze nieuwe kaart kan tevens dienen als beschrijving van de T0-situatie waaraan de effecten van gedempt getij op de Natura 2000-habitattypen en soorten kunnen getoetst worden.

Het verdient de aanbeveling om de planuitwerkingsfase te benutten voor nader onderzoek en studie naar mitigerende maatregelen bijvoorbeeld door:

- Het opstellen van een systeemrapportage waarin alle beschikbare data en kennis worden geanalyseerd en verzameld en waarin, in tegenstelling tot eerdere bekkenrapportages, ook de droge delen op de oevers en eilanden integraal mee in beschouwing worden genomen (incl. eco-hydrologische processen). 
- De systeemrapportage kan als basis dienen voor het uitvoeren van een intensief meetjaar om beter grip te krijgen op voornamelijk de grote onzekerheden m.b.t. de lagere trofische niveaus (fyto-/zoöplankton, bodemdieren) in relatie tot hogere trofische niveaus (vissen en vogels) en causale verbanden te onderzoeken tussen de verschillende fysische, morfologische en ecologische processen en daarbij horende biodiversiteit.

- Het benutten van de Flakkeese spuisluis om op kleine schaal te testen, bijvoorbeeld met een microgetij van $10 \mathrm{~cm}$.

- Studie naar mitigerende maatregelen en hun effectiviteit om (gewenste) natuurwaarden in het Grevelingenmeer op korte en lang termijn te behouden of te ontwikkelen.

- Optimaliseren oeververdedigingen met 'nature-based solutions': nu zijn de oeververdedigingen aangelegd met breukstenen. 


\section{Inleiding}

\subsection{Achtergrond}

Het 'Programma Ontwikkeling Grevelingen en Volkerak-Zoommeer' (2019-2026) ${ }^{1}$ is er om een aantal knellende praktische problemen in deze bekkens op te lossen: zuurstofloze waterlagen in het Grevelingenmeer en overlast van blauwalgen in het Volkerak-Zoommeer. Dit programma is voortgekomen uit de Rijksstructuurvisie Grevelingen en Volkerak-Zoommeer (afgekort met RSV) waarin oplossingsrichtingen zijn verkend om de waterkwaliteit te verbeteren als voorbereiding op een Rijksbesluit. De effecten van verschillende alternatieven zijn in beeld gebracht in een milieueffectrapportage (MER) (I\&M 2014) en een maatschappelijke kosten-batenanalyse (MKBA) (Stratelligence, 2014). Als input voor het natuur-deel van de MER is de Natuur Effecten Studie (NES) uitgevoerd waarin de effecten van de verschillende ingrepen op beschermde natuur op kwalitatieve wijze in beeld zijn gebracht en getoetst aan de natuurwetgeving (Dienst Landelijk Gebied 2014a; Dienst Landelijk Gebied 2014b). Later zijn in een aanvullende natuureffectenstudie de effecten verder kwantitatief uitgewerkt (Royal HaskoningDHV 2017). In oktober 2014 is de ontwerp-RSV door het kabinet vastgesteld waarin het volgende ontwikkelperspectief wordt geschetst voor het Grevelingenmeer en het Volkerak-Zoommeer (Ministerie van Infrastructuur en Milieu 2014):

- Het Grevelingenmeer krijgt beperkt getij terug van $50 \mathrm{~cm}$ via een doorlaat in de Brouwersdam die de Grevelingen verbindt met de Noordzee. Het Rijk biedt hiermee ook ruimte aan private partijen voor de opwekking van duurzame getijdenenergie.

- Het Volkerak-Zoommeer wordt weer zout en krijgt beperkt getij terug via een doorlaat in de Philipsdam die het Volkerak-Zoommeer verbindt met de Oosterschelde. Hieraan vooraf worden maatregelen genomen voor een alternatieve zoetwatervoorziening voor landbouwgebieden die nu afhankelijk zijn van zoetwater uit het Volkerak-Zoommeer en maatregelen om zoutindringing te beperken.

- Waterberging op de Grevelingen is niet nodig voor de waterveiligheid in de Rijn-Maasdelta (geen kosteneffectieve oplossing).

Het Programma Ontwikkeling Grevelingen en Volkerak-Zoommeer oriënteert zich op mogelijke oplossingsrichtingen. In de voorbereiding is de optie waarbij er een verbinding tussen het Grevelingenmeer en Volkerak-Zoommeer wordt gemaakt afgevallen waardoor de uitwerking voor beide wateren met minder samenhang zal verlopen. Voorliggend rapport gaat in op het Grevelingenmeer. In maart 2018 kondigde het kabinet aan dat 75 miljoen euro vrij zal worden gemaakt voor een doorlaat in de Brouwersdam. ${ }^{2}$

\subsection{Aanleiding: waarom nog een natuurstudie?}

In de planvorming is voor het Grevelingenmeer gekeken naar kansen vanuit verschillende invalshoeken zoals waterkwaliteit, getijdenenergie en waterveiligheid. Natuurorganisaties zijn van mening dat hierbij maar beperkte aandacht is geweest voor effecten op en mitigatiemogelijkheden voor de huidige natuurwaarden en kansen voor het verzilveren van nieuwe (estuariene) natuurwaarden. Binnen de natuureffectenstudie is vooral gekeken naar beschermde natuurwaarden vanuit de juridische kaders die voortkomen uit de natuurwetgeving.

In 2014 heeft het toenmalige ministerie van Economische Zaken (nu LNV) de 'Natuurambitie Grote Wateren 2050 en verder' opgesteld die dient als inspirerende visie en richtlijn voor beleidsmakers. Doel is om deze beleidsvisie te verbinden met lopende wateropgaven. Over het Grevelingenmeer worden o.a. de volgende ambities benoemd met als tijdshorizon 2050 en verder (Ministerie van Economische Zaken 2014):

- Ontwikkeling robuust en veerkrachtig systeem

- Kansen voor ontwikkeling van estuariene natuurwaarden

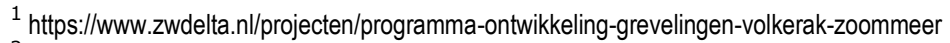

${ }^{2}$ https://www.rijksoverheid.nl/actueel/nieuws/2018/03/07/kabinet-pompt-275-miljoen-euro-in-gezonde-natuur-en-water
} 
- Natuur heeft baat bij herziening van compartimentering en (deels) herstel van verbindingen tussen de Deltawateren en de Noordzee

- Bij gedempt getij dient er aandacht te zijn voor mogelijke effecten van zandhonger en een kosten-baten afweging

- $\quad$ RSV is bepalend voor de komende decennia

Het ministerie van Landbouw, Natuur en Voedselkwaliteit (LNV) vindt het van belang dat het perspectief en de kansen voor natuur in het Grevelingenmeer grondiger wordt uitgediept en dat natuurpartijen en beheerders hierbij worden betrokken. Daarom heeft zij Wageningen Marine Research gevraagd om dit nader te onderzoeken.

\subsection{Doel}

Het doel van deze studie is drieledig:

a. Het kwantitatief beschrijven van de potentiële verschuiving van ecotopen voor verschillende scenario's van waterbeheer met gedempt getij in het Grevelingenmeer.

b. Het kwalitatief beschrijven van de potentiële ontwikkeling van natuurwaarden met focus op de in samenspraak met de opdrachtgever en betrokkenen aangegeven speerpunten:

- $\quad$ Autonome ontwikkeling van de vegetatie en bij gedempt getij inclusief de ontwikkeling van de zoetwaterbel

- Verwachte kansen/effecten voor broedvogels en mogelijke (beheers)maatregelen

- Aangeven winst/verlies rekening van Natura 2000-habitattypen Vochtige duinvalleien - kalkrijk H2190B en Zilte pionierbegroeiingen - zeekraal H1310A per scenario

- De rol van slib en mogelijke vertroebeling van de waterkolom

- Ontwikkeling van de zuurstofconcentratie boven de waterbodem

- Ontwikkeling primaire productie en doorwerking in het voedselweb (zoöplankton, benthos, vissen en vogels)

- Ontwikkeling bodemleven in het nieuwe intergetijdengebied en betekenis als foerageergebied voor vogels

- Effecten zandhonger

c. Aangeven van mogelijke kansen voor optimalisatie van waterbeheer ten bate van specifieke (of gewenste) natuurwaarden.

\subsection{Uitvoering}

Vanwege de hydromorfologische en biochemische kennis en modelvaardigheden die nodig zijn bij het voorspellen van gevolgen van mogelijk toekomstig waterbeheer is Deltares mede-uitvoerder van dit onderzoek. Daarnaast is ook Wageningen Environmental Research (net als Wageningen Marine Research onderdeel van Wageningen Universiteit \& Research) mede uitvoerder vanwege terrestrisch ecologische kennis (in het bijzonder de vegetatieontwikkeling op eilanden en oevers van het Grevelingenmeer). Daarnaast hebben een tiental mensen input geleverd in de gehouden workshops, expertsessies, consultatie en interviews. Dit wordt nader besproken in Hoofdstuk 2 'Werkwijze'.

\subsection{Afbakening}

In de uitwerking wordt het voorkeursalternatief van de ontwerp-RSV met $50 \mathrm{~cm}$ getijslag via een doorlaat in het noordelijk deel van de Brouwersdam als basis gehanteerd. Het effect van variatie in (1) getijslag, (2) peilbeheer en (3) zeespiegelstijging is vervolgens in verschillende scenario's onderzocht en de gevolgen voor de natuurwaarden zijn ingeschat. De focus van deze studie ligt daarbij op de veranderingen vanuit een systeemperspectief en deels op toetsing van beschermde natuurwaarden aan Natura 2000-wetgeving. Dit laatste is al eerder in de natuureffectenstudies gedaan (Dienst Landelijk Gebied 2014a; Dienst Landelijk Gebied 2014b; Royal HaskoningDHV 2017). Wel worden potentiële effecten van gedempt getij in de scenario's op Natura 2000-habitattypen H1310A (Zilte pionierbegroeiingen - zeekraal) en H2190B (Vochtige duinvalleien - kalkrijk) ingeschat en 
bediscussieerd. Waar relevant worden de verschillen met eerdere studies (met name Royal HaskoningDHV 2017) besproken.

Omdat het inschatten van de ecologische gevolgen van de verandering van het Grevelingenmeer van een stagnant zout meer naar een meer dynamisch systeem met een beperkte getijslag vele facetten kent en de middelen voor dit onderzoek niet toereikend zijn om al deze facetten uit te diepen, zijn in samenspraak met de opdrachtgever en in overleg met natuurpartijen en beheerders een aantal speerpunten gedefinieerd. Deze speerpunten vertegenwoordigen de onderwerpen waar in de uitwerking de nadruk op ligt. De speerpunten staan in Hoofdstuk 2 weergegeven.

\subsection{Beperkingen}

Een belangrijke beperking van dit onderzoek is de onzekerheid van het verloop van het hoogteprofiel van de ondiepe oevers tussen -0,20 en -1,50 m NAP. Het verloop van de oevers is geïnterpoleerd (op basis van een combinatie van de diepteloding van het gebied en het Actueel Hoogtegestand (AHN)) om zo een ruwe inschatting te kunnen maken van het profiel. De resultaten geven hierdoor echter geen nauwkeurig beeld van de oppervlakten van ecotopen op het grensvlak van land en water: ondiep water, terrestrisch en (toekomstig) intergetijdengebied. Daarom is voorzichtigheid geboden bij het interpreteren van de resultaten omdat deze slechts de globale verschuivingen van ecotopen in een stagnante situatie (=huidige situatie met peilbeheer) en voor verschillende getijscenario's aangeven (Hoofdstuk 5). Daarnaast is het van belang om te benadrukken dat de ecotopenkaarten die in deze studie zijn gemaakt statische begrenzingen aangeven die in werkelijkheid dynamisch zijn (bv. door fluctuerende waterstanden als gevolg van windopzet etc.) en geen inzicht geven in de kwaliteit en ontwikkeling van natuurwaarden in de tijd. Dit laatste wordt met behulp van expertoordeel bediscussieerd (Hoofdstuk 6). In een aparte paragraaf (8.5) wordt meer in detail ingegaan op de beperkingen en onzekerheden van deze studie, en worden op basis hiervan aanbevelingen en kennisleemtes geformuleerd. 


\section{Werkwijze}

Door Nolte et al. (2013), Ysebaert et al. (2013a), Ysebaert et al. (2013b), is eerder een soortgelijke scenariostudie uitgevoerd gericht op de gehele Zuidwestelijke Delta waarin ook het Grevelingenmeer is meegenomen. In 2012 is hiervoor een methode ontwikkeld om de ruimtelijke verschuiving van habitats of ecotopen te kunnen voorspellen met behulp van modelberekeningen voor verschillende scenario's. In samenspraak met de opdrachtgever is deze methode gebruikt als basis voor deze studie.

In dit hoofdstuk wordt de werkwijze toegelicht. Hierbij zijn de volgende stappen onderscheiden:

- Formuleren scenario's (met betrokkenen)

- Ecologische onderbouwing: definiëren ecotopen

- Modelleren scenario's OD- en 3D-model

- Uitwerken ecotopenkaarten (GIS-analyse) en bepalen ecotoop arealen voor elk scenario

- Beoordeling van de scenario's (literatuurstudie/expert oordeel)

- Effect op Natura 2000 habitattypes

Hieronder wordt iedere stap nader besproken.

\subsection{Formuleren scenario's en inhoudelijke speerpunten met betrokkenen}

De keuzes die gemaakt worden in het opbouwen van de scenario's zijn bepalend voor de verdere uitwerking. Om goede en gedragen keuzes te kunnen maken is het daarom van belang om vanaf het begin met betrokken natuurpartijen en beheerders gezamenlijk de scenario's te identificeren die de belangrijkste vragen die spelen ondervangen. Voor het vastleggen van de scenario's en communicatie met betrokkenen zijn daarom de volgende stappen doorlopen:

- Overleg met de opdrachtgever (ministerie van LNV) over achtergrond, focus, te betrekken partijen, doel en tijdspad van het onderzoek en de inbedding in lopende (gebieds-)processen

- Deskstudies van de bestaande stukken: zienswijzen en onderbouwende documenten van het RSV-traject

- Overleggen met betrokkenen om de onderzoeksopzet te presenteren, de focus ervan te detailleren, en om speerpunten te identificeren ten behoeve van het definiëren van de definitieve scenario's:

> Overleg met Coalitie Delta Natuur (CDN) op 6 september 2016 in Zeist. CDN is een overkoepelende (natuur)organisatie voor de deltanatuur, die de volgende organisaties vertegenwoordigd: Brabantse Milieufederatie, Brabants Landschap, Het Zeeuwse Landschap, Natuur en Milieufederatie Zuid-Holland, Stichting ARK, Wereld Natuur Fonds, Vogelbescherming, Natuurmonumenten, Staatsbosbeheer, Het ZuidHollands Landschap, Bureau Stroming (Bijlage A).

$>$ Overleg met Natuur- en Vogelwacht Schouwen-Duiveland (NVSD) op 3 oktober 2016 in Moriaanshoofd (Bijlage B).

- Organisatie "Verdiepingsworkshop Scenariostudie Grevelingenmeer" op 24 oktober 2016 in Rotterdam: overleg met betrokkenen met als doel om de te onderzoeken scenario's te bediscussiëren. Daarnaast is gesproken over de belangrijkste inhoudelijke speerpunten waar focus op gelegd kan worden. Hierbij konden betrokkenen aangeven welke onderwerpen ze van belang vinden. Dit was nodig omdat niet alle aspecten, habitats en soorten(groepen) tot in detail kunnen worden uitgediept binnen de scope van deze studie (Bijlage C).

- Vastleggen van de voorlopige scenario's op basis van de input van betrokkenen en randvoorwaarden vanuit het onderzoek (bv. beschikbaar budget, (model-)beperkingen).

- Uiteindelijke keuze van de te onderzoeken definitieve scenario's in samenspraak met betrokkenen en met de opdrachtgever.

- Tussentijdse terugmelding van de resultaten aan betrokkenen op 26 oktober 2017 (Bijlage D).

De nadruk van deze studie zal liggen op de volgende 'speerpunten' die samen met betrokkenen en in overleg met de opdrachtgever zijn geformuleerd: 
Natuurwaarden oevers en eilanden

- Autonome ontwikkeling van de vegetatie bij gedempt getij en ontwikkeling zoetwaterbel

- Verwachte kansen/effecten voor broedvogels en mogelijke (beheers)maatregelen

- Aangeven winst/verlies rekening van Natura 2000-habitattypen 'Vochtige duinvalleien' (H2190B) en 'Zilte pionier begroeiingen - zeekraal' (H1310A) per scenario in een situatie met gedempt getij. NB: Het verlies aan habitats door overspoeling per scenario wordt kwantitatief weergegeven. In hoeverre habitats kunnen opschuiven wordt op basis van expertoordeel kwalitatief bediscussieerd.

Onderwaternatuur in een getijdesituatie

- De rol van slib en mogelijke vertroebeling

- Ontwikkeling van de zuurstofconcentratie bij de bodem

- Ontwikkeling primaire productie en doorwerking in het voedselweb (zoöplankton, benthos, vissen en vogels)

- Ontwikkeling bodemleven in nieuw intergetijdengebied en betekenis als foerageergebied

- Effecten zandhonger en mitigerende maatregelen

\subsection{Ecologische onderbouwing: definiëren van ecotopen}

Om een beeld te kunnen geven van de te verwachten natuurtypen per scenario is gekozen om een indeling in ecotopen te hanteren. Ecotopen zijn ruimtelijk te begrenzen ecologische eenheden, waarvan de samenstelling en ontwikkeling worden bepaald door abiotische, biotische en antropogene condities ter plaatse. Een ecotoop is een herkenbare, min of meer homogene landschappelijke eenheid (Bouma et al. 2005). Een ecotopenstelsel is een classificatiesysteem van ecotopen waarin de van belang zijnde ecotopen in een gebied (watersysteem) op overzichtelijke wijze gerangschikt zijn. Ecotopenkaarten worden afgeleid uit een aantal onderliggende kaarten van in hoofdzaak fysische factoren (bijv. zoutgehalte, droogvalduur), die samen de kenmerken van een ecotoop bepalen. Het identificeren van ecotopen is een middel om veranderingen in een watersysteem op het niveau van habitats en de daarbij horende levensgemeenschappen in ruimte en tijd te kunnen volgen en evalueren.

De eerste stap is dus het definiëren en beschrijven van de relevante ecotopen zodat ze als kader dienen voor de invulling van de scenario's. Dit vormt de ecologische onderbouwing van deze scenariostudie en is nodig om een gerangschikt overzicht te krijgen van aanwezige/toekomstige ecotopen in het Grevelingenmeer. Deze ecotopenindeling vormt weer de basis voor de ontwikkeling van ecotopenkaarten die de doorwerking van aanpassingen in waterbeheer in ieder scenario op de ecologie verbeelden. De volgende stappen zijn doorlopen:

- Discussie met het projectteam over welke ecotopen gedefinieerd moeten worden uitgaande van de scenario's die zijn geformuleerd (zie hieronder).

- Beschrijven van abiotische randvoorwaarden en variatie en de kenmerkende soorten per ecotoop. Hierbij is gebruik gemaakt van het Ecotopenstelsel voor de Zoute Wateren (Bouma et al. 2005), een eerdere scenariostudie (Ysebaert et al. 2013a), Natura 2000-habitattypen profieldocumenten en andere literatuur.

\subsection{Modelleren scenario's OD en 3D model}

Met behulp van watersysteemmodellen zijn voor elk scenario de relevante parameters berekend (waterbeweging, waterkwaliteit, primaire productie), op basis waarvan de omvang (areaal) en de kwaliteit van de ecotopen zijn bepaald.

De beschikbare watersysteemmodellen voor het Grevelingenmeer vallen onder het programma 'Beheer, Onderhoud en Ontwikkeling (BOO)' van gebiedsmodellen die Deltares in opdracht van Rijkswaterstaat beheren (KPP BOO Waterkwaliteitsmodelschematisaties). Dit betreft gebiedsmodellen van waterbeweging, zoutindringing en -verspreiding, temperatuur, slib, waterkwaliteit en ecologie. Voor het 
Grevelingenmeer zijn 7 modellen in BOO opgenomen met de volgende formele codering (conventie voor naamgeving Software_Gebied_Jaar_versienummer):

- $\quad 1$-dimensionaal (1D)

- SOBEK_Zuidwestelijke-Delta_j05-09_v01

○ DELWAQ_Stofstromen-Zuidwestelijke_Delta-j05_09-v01

- 2-dimensional (2D)

- Simona-Grevelingen-fijn_exvd-1991-v1

- Simona-Grevelingen-grof_exvd-1991-v1

- Waqua-gn_vo_zo-j12_5-v3 3.11 .2

- 3-dimensionaal (3D)

○ Delft3D-FLOW-Grevelingenmeer-j00+08_v01

o DELWAQ-Algen_Grevelingenmeer_j00+08_v01

Naast deze modellen in BOO is in het kader van de ontwerp-RSV een relatief eenvoudig Excelspreadsheetmodel gemaakt, waarin de waterstandsvariatie wordt berekend voor te kiezen beheerscenario's van de doorlaat in de Brouwersdam. Omdat het Grevelingenmeer hierin als een goed gemengd bekken wordt beschouwd, is dit spreadsheetmodel een 0D-model ${ }^{3}$.

Op basis van de in paragraaf 2.1 geïdentificeerde speerpunten wordt in deze paragraaf aangegeven welke (model)variabelen met de beschikbare OD- en 3D-modellen voor waterbeweging en waterkwaliteit en primaire productie berekend zullen worden. Een overzicht wordt gegeven in Tabel 1. Toelichting volgt daarna.

Tabel 1. Modelkeuze per doelvariabele.

\begin{tabular}{|c|c|c|c|}
\hline Doelvariabele & Eenheid & Model & Modelkeuze \\
\hline $\begin{array}{l}\text { Vernietiging door bouw } \\
\text { doorlaatmiddel }\end{array}$ & Hectare & Geen & $\begin{array}{l}\text { Geen model nodig. Rechtstreeks af te leiden } \\
\text { uit de voetafdruk van het kunstwerk. }\end{array}$ \\
\hline Areaal intergetijdengebied & Hectare & \multirow[t]{2}{*}{$3 D$} & \multirow[t]{2}{*}{\begin{tabular}{|l} 
1) $\begin{array}{l}\text { Combinatie van waterstand berekend met } \\
\text { 3D-model en bodemhoogtekaart }\end{array}$ \\
2) $\begin{array}{l}\text { Waterstand door windopzet op basis van } \\
\text { rekenregels (strijklengte en } \\
\text { windsnelheid) }\end{array}$ \\
3D-model waterbeweging Grevelingenmeer
\end{tabular}} \\
\hline Peilverhoging & m NAP & & \\
\hline Zoutgehalte- en gradiënt & psu & $3 D$ & 3D-model waterbeweging Grevelingenmeer \\
\hline Zuurstofconcentratie bij de bodem & $\mathrm{mg} / \mathrm{l}$ & & \multirow{2}{*}{$\begin{array}{l}\text { 3D-model waterkwaliteit en primaire } \\
\text { productie Grevelingenmeer }\end{array}$} \\
\hline $\begin{array}{l}\text { Chlorofyl-A concentratie } \\
\text { (alternatief biomassa algen) }\end{array}$ & $\begin{array}{l}\mu g / l \\
(\mathrm{mg} \mathrm{C} / \mathrm{I})\end{array}$ & & \\
\hline Doorzicht & M & $3 D$ & $\begin{array}{l}\text { Een 3D-model is essentieel om de stratificatie } \\
\text { te kunnen berekenen, die sturend is voor het } \\
\text { optreden van zuurstofloosheid. Met een 1D- } \\
\text { of 2D-model is dat niet mogelijk. }\end{array}$ \\
\hline
\end{tabular}

De variabelen die gekoppeld zijn aan de waterstand, areaal van het intergetijdengebied en peilverhoging kunnen met het 3D-model berekend of afgeleid worden. Het 3D-model heeft de debieten door de Brouwerssluis, de Flakkeese spuisluis en de nieuwe doorlaat in de Brouwersdam nodig als modelinvoer. Deze worden daarom eerst afgeleid met een 0D-model met een tijdstap van 10 minuten (paragraaf 5.1).

Voor de overige doelvariabelen wordt het 3D-model voor waterbeweging en voor waterkwaliteit en primaire productie ingezet. Een 3D-model waarin verticale profielen van zout en temperatuur leidend tot stratificatie en tot mogelijke uitputting van zuurstof in de onderlaag berekend kunnen worden, is in ieder geval nodig om de zuurstofconcentratie bij de bodem uit te rekenen. Met een 1D-model en een

\footnotetext{
${ }^{3}$ Er zijn overigens door meerdere partijen die aan het Rijksstructuurvisietraject hebben bijgedragen, vergelijkbare OD-modellen gemaakt. Ook het Hydro Meteo Centrum Zeeland (HMZC) heeft een OD-model dat voor vragen rondom het peilbeheer van het Grevelingenmeer wordt gebruikt.
} 
2D-model kan dat niet. Met het 3D-model worden tevens ruimtelijke patronen inzichtelijk. Het 3D-model zal de waterbalans gaan hanteren die door het OD-model is opgesteld. De waterbalans - dat wil zeggen de debieten door de Bouwerssluis, de Flakkeese spuisluis en de nieuwe doorlaat in de Brouwersdam zoals berekend met het $0 \mathrm{D}$-model is opgelegd aan het 3D- model. Polderlozingen, neerslag en verdamping zijn ook opgenomen in het 3D-model. Dit wordt in de waterbalans gesloten door deze debieten netto ook via de Brouwersdam uit te laten stromen. Het betreft een kleine term (orde 1-2 $\mathrm{m}^{3} / \mathrm{s}$ ) ten opzichte van de debieten door de doorlaat (orde $1.000 \mathrm{~m}^{3} / \mathrm{s}$ ).

Modelresultaten van het zoutgehalte worden in dit rapport niet getoond, omdat de scenario's daarin voor de ecotopen niet onderscheidend zijn. In alle gevallen is het zoutgehalte hoger dan 18 psu en worden de ecotopen op basis van het zoutgehalte tot de zoute ecotopen gerekend. Conform de huidige situatie varieert het zoutgehalte in het Grevelingenmeer tussen 28 en 30 psu. Als de uitstroom van de Nieuwe Waterweg door noorderwind naar het zuiden wordt gedreven en via de Brouwersdam ingelaten wordt, kan soms een lager zoutgehalte voorkomen.

Een beschrijving van het 0D-model en de 3D-modellen voor waterbeweging en voor waterkwaliteit en primaire productie die in het vervolg van deze studie gebruikt zullen gaan worden, is opgenomen in Bijlage E.

\subsection{Uitwerken ecotopenkaarten (GIS-analyse)}

\subsubsection{Waterstanden}

Voor het uitwerken van de ecotopen is primair gebruik gemaakt van de waterstanden die voor de verschillende scenario's zijn berekend met het 3D-model. Voor 26 locaties, verspreid over het Grevelingenmeer (Figuur 1), zijn de berekende waterstanden opgeslagen over de periode van 1 november 2007 tot en met 31 december 2008 met een tijdstap van één uur. In Bijlage $F$ zijn de berekende waterstanden uitgezet tegen de tijd voor de locaties GTSO-01 (bij Brouwerssluis), GTSO-12 (Bommenede) en GTSO-20 (Grevelingendam nabij Flakkeese Spuisluis). Uit de waterstanden zijn diverse percentielen ( $1 \%, 5 \%, 7 \%, 50 \%, 93 \%, 95 \%$ en 99\%) en de maximale waterstand berekend op alle 26 locaties voor de volledige periode, het winterhalfjaar ( 1 september tot 1 april) en het zomerhalfjaar ( 1 april tot 1 september). Omdat de percentielen niet over het hele gebied hetzelfde zijn (door windopzet zijn de waterstanden in het oostelijk deel van het Grevelingenmeer gemiddeld hoger), zijn de percentielen geïnterpoleerd over het modelgebied middels Inverse Distance Weighting in R. Dit is een interpolatietechniek waarbij locaties die verder weg liggen minder gewicht krijgen.

$$
z_{i}=\frac{\sum_{j=1}^{n}\left(\frac{z_{j}}{d_{i j}{ }^{p}}\right)}{\sum_{j=1}^{n}\left(\frac{1}{d_{i j}{ }^{p}}\right)}
$$

Hierbij is $z_{i}$ de geïnterpoleerde waarde op locatie $i, z_{j}$ de door het model berekende waarde op locatie $j$ en $d_{i j}$ de afstand tussen $z_{j}$ en $z_{i}$ in meter. De parameter $p$ geeft aan hoe snel het gewicht afneemt met de afstand. Voor deze interpolaties is een waarde van $p=4$ gebruikt. Omdat de locatie b03 ten oosten van de Veermansplaat op een relatief ondiepe plek ligt en daardoor droogvalt bij lage waterstanden is deze locatie niet meegenomen voor de berekening van de 1, 5, 7 en 50-percentielen. Deze berekeningen hebben geresulteerd in een gebiedsdekkende kaart (20x20 meter) van de 1\%, 5\%, 7\%, 50\%, 93\%, $95 \%$ en $99 \%$ van de waterstanden en de maximale waterstand.

\subsubsection{Dieptekaart}

De ecotopenkaarten zijn bepaald door de berekende percentielen van de waterstanden te relateren aan de dieptekaart voor het Grevelingenmeer (Figuur 1). De dieptekaart is een combinatie van de vaklodingen die in 2003 door Rijkswaterstaat zijn uitgevoerd in de natte delen en het Algemeen Hoogtebestand Nederland (AHN) van 2001 voor de delen die boven water liggen. De vaklodingen zijn uitgevoerd door middel van singlebeam sonar, waarbij met een boot raaien zijn gevaren over het water. Deze raaien zijn door Rijkswaterstaat geïnterpoleerd tot dekkende kaarten. Omdat ondiepe zones niet zijn bevaren, beperkt de vakloding zich tot de delen die dieper zijn dan 80 tot $150 \mathrm{~cm}$. Het AHN is 
gebaseerd op laseraltimetrie, een techniek waarbij een vliegtuig of helikopter met een laserstraal het aardoppervlak aftast. Deze techniek geeft een gedetailleerd beeld van de hoogteligging op de droge delen. Omdat de laser niet goed door water heen kan meten geeft het AHN geen goed beeld van de delen die onder water staan. Uit het AHN zijn daarom alleen de waarden gebuikt die op het land lagen. Alle waarden op het water zijn verwijderd. Het resultaat was dat er voor de ondiepe (ondieper dan 80 tot $100 \mathrm{~cm}$ ) natte delen van het Grevelingenmeer geen goede dieptemeting beschikbaar was. De diepte van deze delen is voor deze studie geschat middels interpolatie op een $20 \times 20$ meter grid. Deze interpolatie is uitgevoerd door middel van Inverse Distance Weighting (zie boven) tussen de waarden aan de rand van de vakloding aan de ene kant en de overgang tussen land en water aan de andere kant. Op de overgang van land en water is een diepte van $-20 \mathrm{~cm}$ NAP verondersteld.

Ten slotte is een combinatiekaart gemaakt van het AHN voor de droge delen, de vaklodingen voor de diepe delen en het geïnterpoleerde gebied ertussenin. Hierbij prevaleerde het AHN boven de vaklodingen en de vaklodingen boven het geïnterpoleerde gebied.

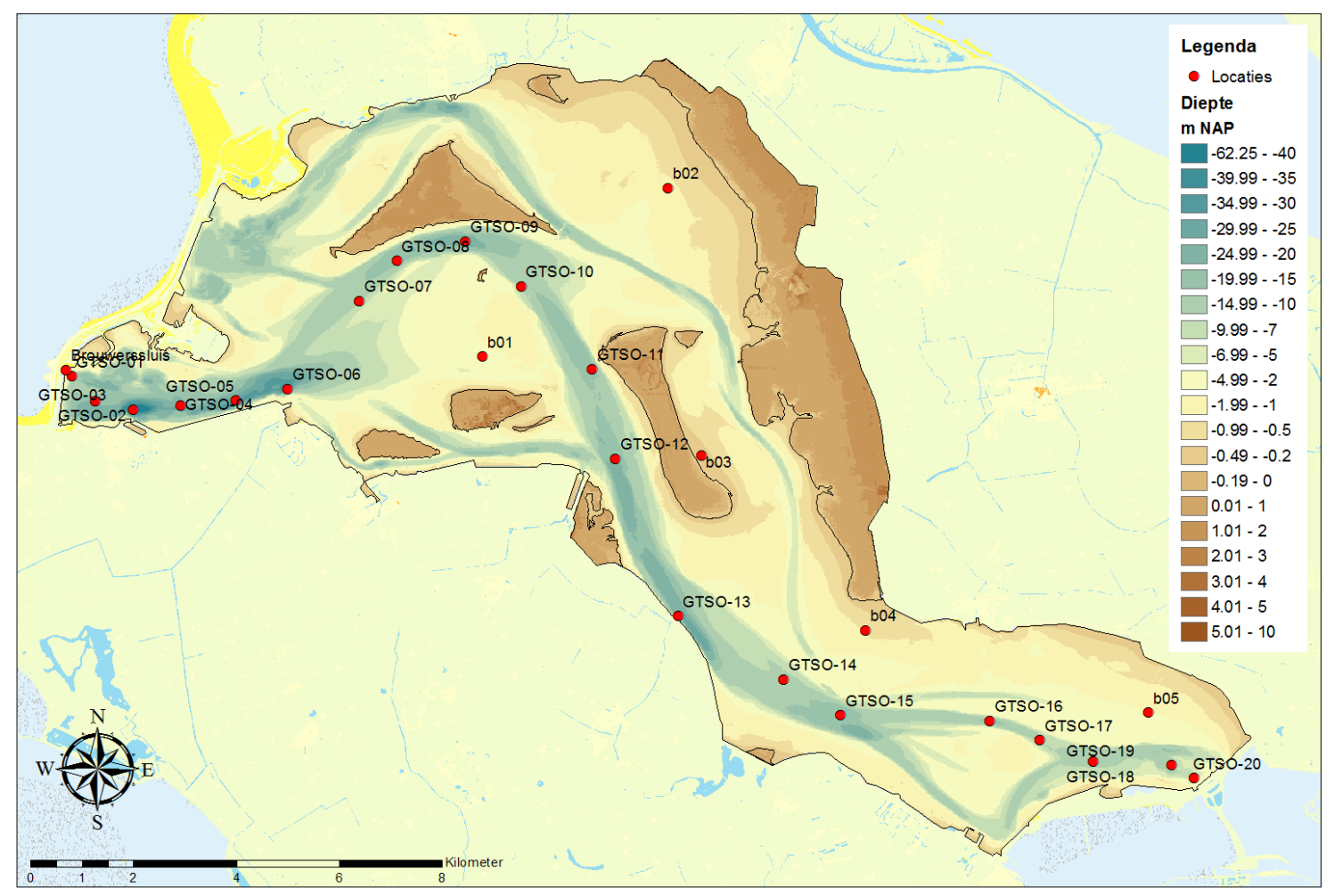

Figuur 1. Dieptekaart Grevelingenmeer zoals gebruikt in deze studie. De rode stippen geven de 26 locaties aan waarvoor de waterstanden zijn gemodelleerd voor de ecotopenkaarten.

Zoals al eerder aangegeven is een belangrijke beperking van dit onderzoek de onzekerheid van het verloop van het hoogteprofiel van de ondiepe oevers tussen -0,20 en -1,50 m NAP. Het verloop van de oevers is geïnterpoleerd op basis van een combinatie van de diepteloding van het gebied en het AHN. De resultaten geven hierdoor mogelijk geen nauwkeurig beeld van de oppervlakten van ecotopen op het grensvlak van land en water: ondiep water, terrestrisch en (toekomstig) intergetijdengebied. In een laat stadium van dit project zijn gedetailleerde hoogteprofielen van de ondiepe zone langsheen een aantal transecten in het Grevelingenmeer door Rijkswaterstaat ter beschikking gesteld en deze geven een beeld van de nauwkeurigheid van de gebruikte oeverprofielen in deze studie. De profielen laten op sommige raaien een goede overeenkomst zien, op andere wijken ze duidelijk af, met name in de diepere delen (Figuur 2). In Bijlage $\mathrm{O}$ staan voor meerdere raaien de profielen weergegeven die gebruikt zijn in deze studie in vergelijking tot de gedetailleerde lodingen van Rijkswaterstaat. In de aanbevelingen van deze studie wordt de noodzaak van geactualiseerde, gebiedsdekkende oeverprofielen benadrukt zodat betere inschattingen van de ecotoop arealen en habitattypes kunnen gemaakt worden. 

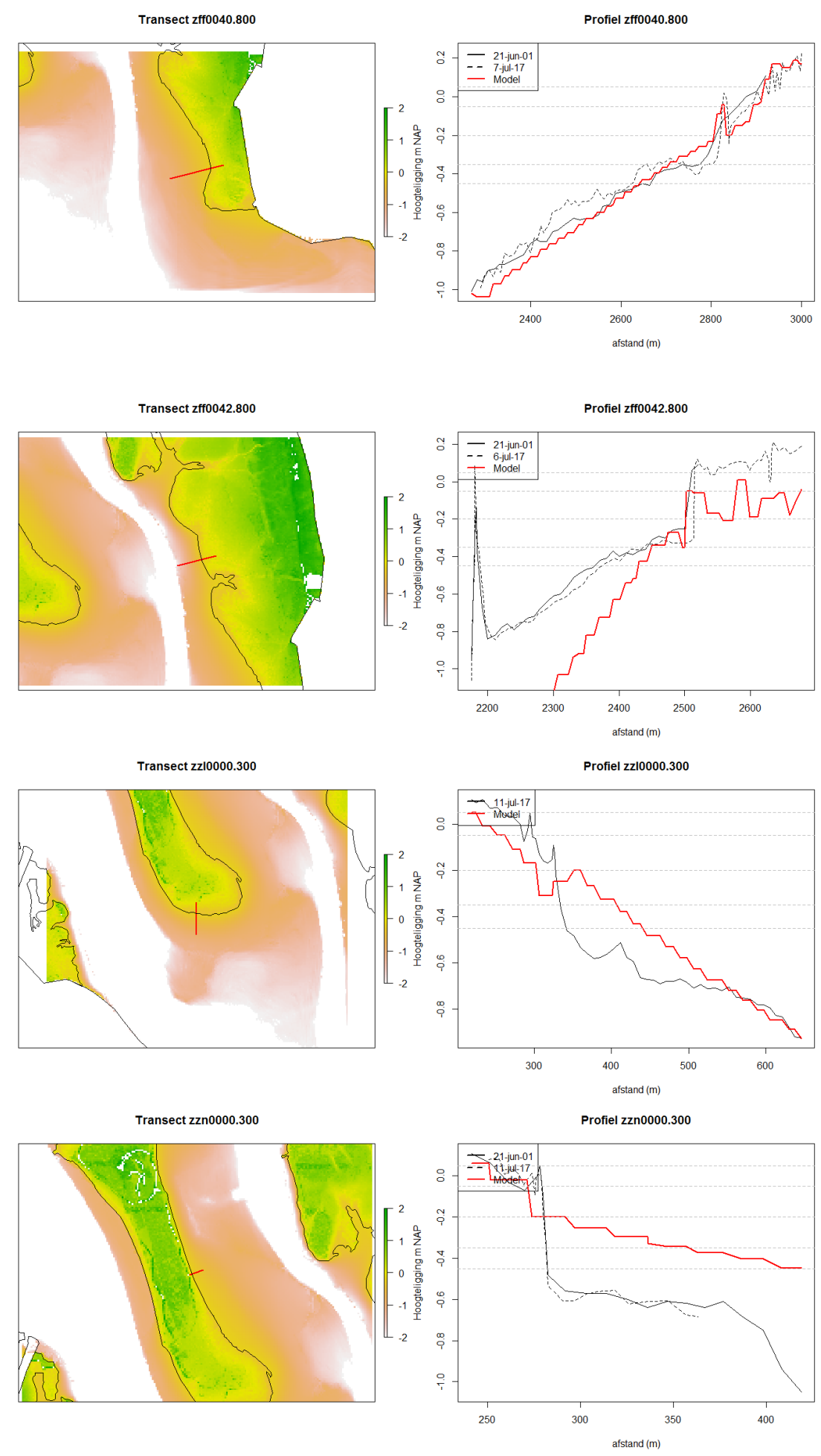

Figuur 2. Transecten van oeverprofielen zoals gebruikt in deze studie (rode lijnen) in vergelijking tot gedetailleerde lodingen uitgevoerd door Rijkswaterstaat (in 2001 en 2017).

\subsubsection{Ecotopenkaart}

Door de berekende percentielen te relateren aan de bodemligging is voor iedere locatie te berekenen of deze meer of minder dan een bepaald percentage van de tijd droogvalt. Bijvoorbeeld locaties waar de bodem hoger ligt dan het 95-percentiel zullen meer dan 95\% van de tijd droogvallen en dus minder dan $5 \%$ van de tijd onder water staan. 
De ecotopen zijn bepaald op basis van de ecotopenindeling (zie paragraaf 3.2). De getijparameters (gemiddeld hoogwater springtij (GHWS), gemiddeld hoogwater (GHW), gemiddeld hoogwater doodtij (GHWD) en gemiddeld laagwater (GLW)) zijn afgeleid uit de berekende percentielen. Op basis van de getijparameters alleen is het niet mogelijk om de grens tussen de ecotopen terrestrisch met zoute invloed (zilte pionierbegroeiingen, zilte graslanden) en terrestrisch zoet te bepalen. Voor deze grens is informatie over de zoutinvloed nodig, onder meer het voorkomen van zout (kwel)water en zoutspray. Zoutspray is het inwaaien van zout dat tot honderden meters landinwaarts kan worden geblazen en vegetatieontwikkeling kan beïnvloeden. De zoutspray is onder meer afhankelijk van de ligging en de oriëntatie van het bodemprofiel. De modellering van de zoutspray is niet eenvoudig en ligt buiten de scope van dit project. Er is daarom voor gekozen om de mate van zoutinvloed af te leiden uit de (huidige) vegetatieopnamen. Deze vegetatieopnamen kunnen gebruikt worden als een proxy voor de mate van zoutinvloed in de huidige situatie. $\mathrm{Er}$ is in deze studie gebruik gemaakt van vegetatieopnamen uit 2005 (Van de Haterd et al. 2010). Het vegetatietype 'zilt grasland' is gebruikt als een indicator tot waar zoutinvloed nog merkbaar is. Bij de huidige situatie is de zoutinvloed berekend uit de bovengrens (75 percentiel) van het voorkomen van het vegetatietype Zilt Grasland van 12 voormalige slikken en platen in het Grevelingenmeer (Figuur 3 en Figuur 4). Voor ieder van deze locaties is het verschil tussen de hoge delen (75 percentiel) van het vegetatietype 'zilt grasland' en het waterpeil in het Grevelingenmeer in de zomer (-26 cm NAP) berekend. Omdat dit niet voor iedere locatie hetzelfde is (Slikken van Flakkee Noord bijvoorbeeld ligt dit op bijna $+30 \mathrm{~cm}$ NAP en bij Markenje op $0 \mathrm{~cm}$ NAP) zijn de hoogtes geïnterpoleerd middels Inverse Distance Weighting om tot een gebiedsdekkende kaart te komen voor het ecotoop terrestrisch met zoutinvloed. Vervolgens is het verschil tussen deze hoogtes en het waterpeil in de zomer ( $-26 \mathrm{~cm}$ NAP) berekend. Dit leidt tot een zoutinvloed van bijv. $56 \mathrm{~cm}$ boven het waterniveau op de Slikken van Flakkee en $26 \mathrm{~cm}$ op Markenje.

Voor de scenario's zijn deze (verticale) effecten van zoutinvloed opgeteld bij het 99percentiel van de waterstanden ( $\sim$ maximale waterstand). De hier gedefinieerde zoutinvloed is vermoedelijk in de scenario's met getij een overschatting, aangezien er hier vanuit gegaan wordt dat deze zilte vegetaties volledig naar boven kunnen opschuiven. Onder invloed van windopzet en spatwater zal inderdaad zich hogerop een zoute oeverzone ontwikkelen met zilte vegetaties, maar deze zone zal in werkelijkheid smaller zijn dan in de huidige situatie waar de zilte vegetaties ook nog profiteren van zout uit de bodem wat nog aanwezig is van voor de afsluiting. Daarnaast zal dit ook afhankelijk zijn van hoe de zoetwaterbel zich gaat ontwikkelen in een getijde situatie. 


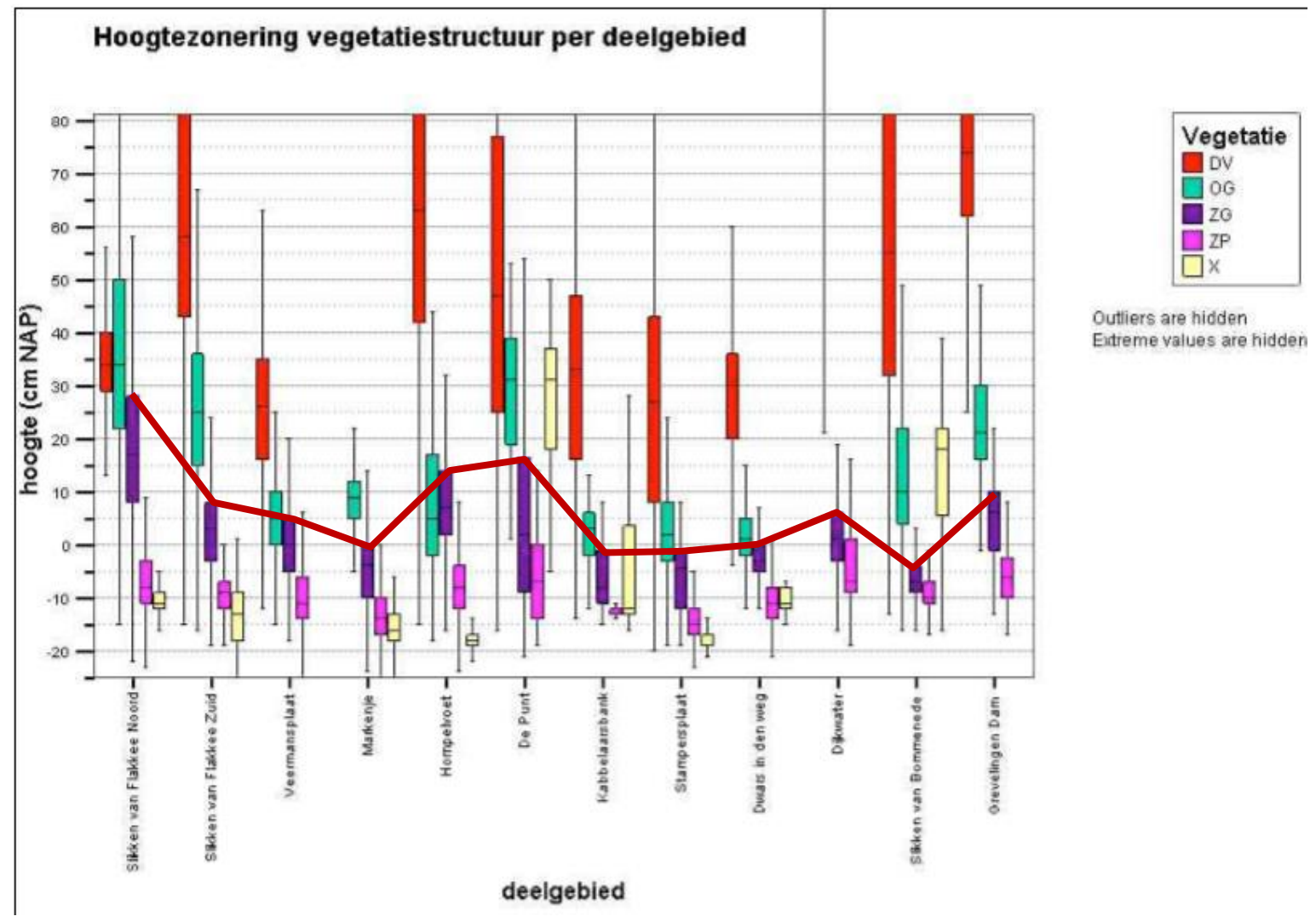

Figuur 3. Boxplots van de hoogteligging van vier vegetatietypen op basis van het Actueel Hoogtebestand Nederland $(A H N) . D V=$ duinvalleivegetaties, $O G=$ Overstromingsgrasland, $Z G=$ Zilt grasland en $Z P=Z i l t e$ pioniers. Rode lijn geeft de bovengrens van de box (75 percentiel) voor het vegetatietype ZG: Zilt grasland (naar Van de Haterd et al. 2010).

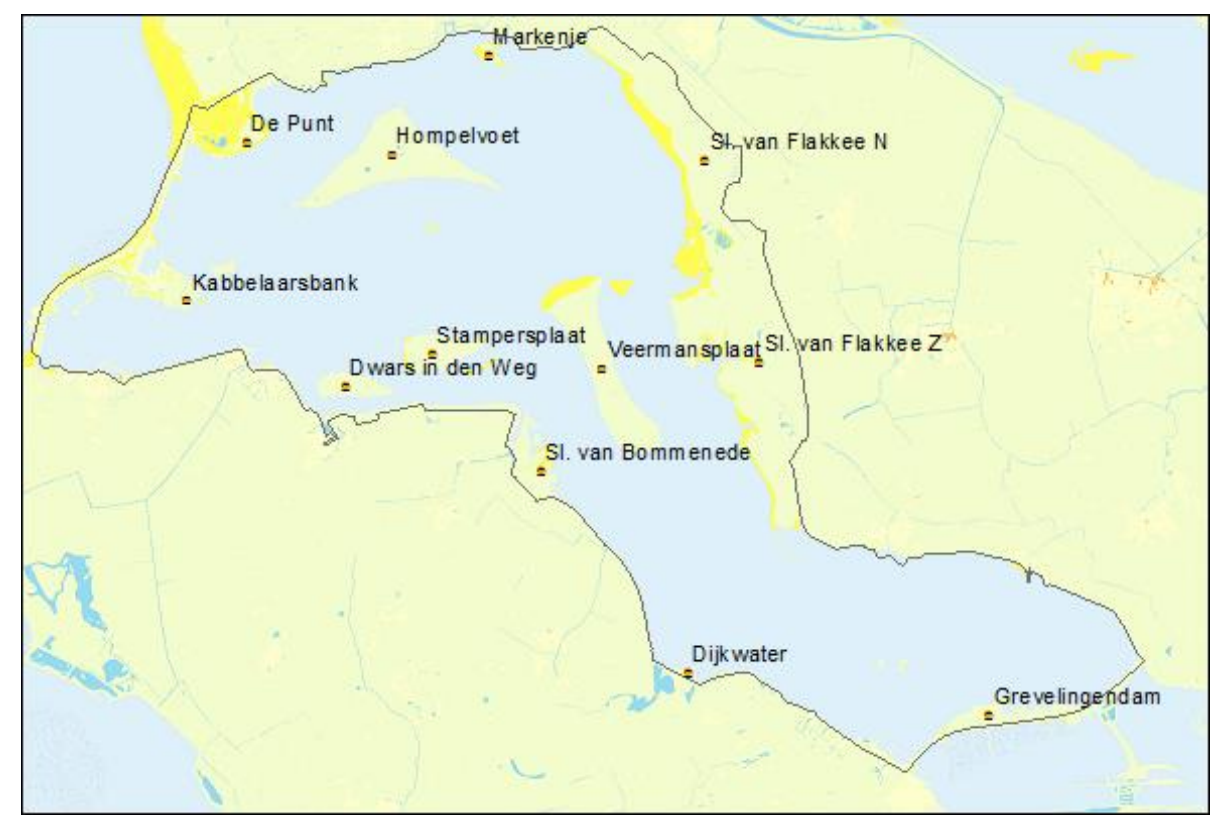

Figuur 4. Ligging van de voormalige slikken en platen in het Grevelingenmeer waarvoor de hoogte van de zoutinvloed is bepaald op basis van de vegetatiekartering. In de onderliggende topografische kaart (Top 10) wordt onderscheid gemaakt in zand (gele gebieden) en alle andere sedimenttypes (lichtgroene gebieden). 


\subsection{Beoordeling van de scenario's}

Voorafgaand aan dit onderzoek zijn vele onderzoeken uitgevoerd die zijn geïnitieerd vanuit het planvormingsproces over het toekomstige waterbeheer van het Grevelingenmeer. In deze studie is getracht om zo goed mogelijk gebruik te maken van deze beschikbare kennis. Om steeds inzicht te kunnen geven in welke bronnen zijn gebruikt wordt in ieder hoofdstuk beknopt aangegeven waar resultaten op zijn gebaseerd (modelstudie, literatuur, expertoordeel, etc.).

Het inschatten van toekomstige kwaliteit van natuurwaarden is gedaan met hulp van diverse experts en/of gebiedskenners van onderzoeks-/adviesbureaus, lokale natuurpartijen en beheerders. Hiervoor zijn in het najaar van 2017 twee expertsessies georganiseerd op 7 en 16 november (zie verslagen in Bijlage G). Daarnaast zijn experts van Bureau Waardenburg geïnterviewd over de zuurstofproblematiek in relatie tot het bodemleven (zie verslag in Bijlage $\mathrm{H}$ ). Ook is grondwaterdeskundige Perry de Louw (Deltares) geconsulteerd over de verwachte ontwikkeling van de zoetwaterbellen in een situatie met gedempt getij. Tot slot is dit rapport becommentarieerd door Bernadette Botman (voormalig medewerker Royal HaskoningDHV, nu B2Consultancy), projectleider en medeauteur van de aanvulling op de natuureffectenstudie (Royal HaskoningDHV 2017).

\subsection{Effect op Natura 2000 habitattypes}

Een wens vanuit betrokkenen was om ook inzichtelijk te maken in welke mate de Natura 2000habitattypen worden beïnvloed. Omdat dit geen hoofdfocus van deze studie is (dit is immers reeds in de natuureffectenstudies en MER al bekeken) is besloten om enkel voor de habitattypen H1310 (Zilte pionierbegroeiingen) en $\mathrm{H} 2190 \mathrm{~B}$ (Vochtige duinvalleien - kalkrijk) na te gaan hoeveel areaal overspoeld wordt omdat deze habitattypen worden beschouwd als de meest waardevolle habitattypen die door getij zullen worden beïnvloed. Voor het Grevelingenmeer is echter nog geen goedgekeurde Natura 2000 habitatkaart beschikbaar. Daarom is de analyse uitgevoerd op basis van twee beschikbare kaarten:

- Habitatkaart Grevelingen, Rijkswaterstaat: gebaseerd op een ecotopenkartering van Rijkswaterstaat door analyse van luchtfoto's uit 2011 en aanvullend veldwerk (Bureau Waardenburg, 2013).

- Ministerie van Economische zaken, Landbouw en Innovatie, 2011: gebaseerd op vegetatie karteringen in 2001, 2004, 2006 en voor sommige gebieden op de habitatkaart van Rijkswaterstaat uit 2006 aangevuld met veldbezoeken (Alterra Wageningen UR, 2011).

Beide habitatkaarten staan weergegeven in Figuur 5.

Om te bepalen in welke mate habitattypen onder invloed van getij komen te staan is de verspreiding van de habitattypen $\mathrm{H} 1310$ en $\mathrm{H} 2190 \mathrm{~B}$ geplot op de berekende gebieden sublitoraal, litoraal en terrestrisch voor de verschillende scenario's voor de twee beschikbare habitatkaarten (Bijlage $\mathrm{N}$ ). Daarnaast is op basis van expert oordeel ingeschat hoe deze habitattypen ook indirect beïnvloed worden door het terugbrengen van getij en in welke mate ze nog zouden kunnen opschuiven. 

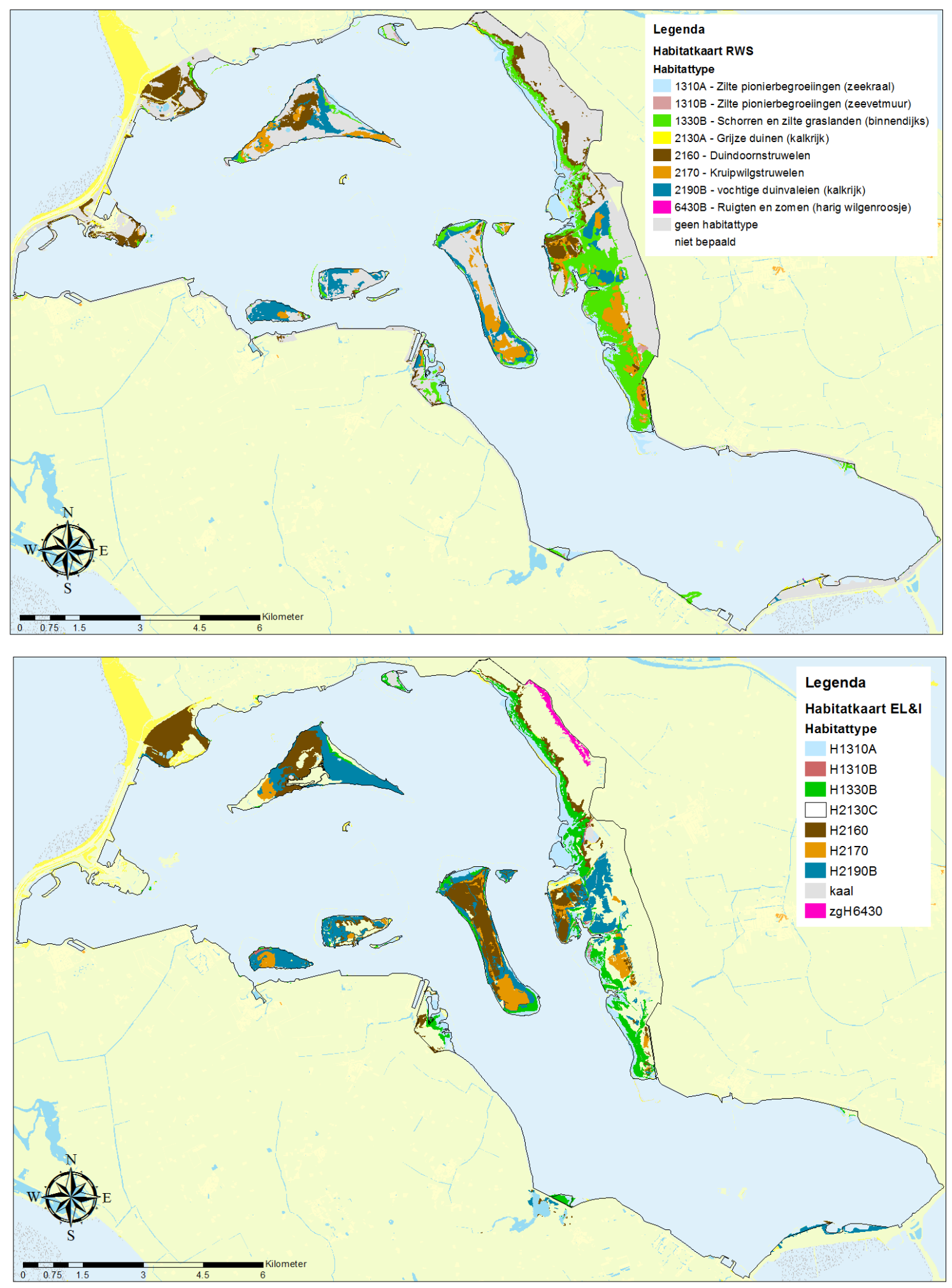

Figuur 5. Natura 2000 habitatkaarten van het Grevelingenmeer. Boven: kaart ontwikkeld in opdracht van Rijkswaterstaat (Bureau Waardenburg, 2013). Onder: kaart ontwikkeld in opdracht van (destijds) ministerie van Economische Zaken, Landbouw en Innovatie (Alterra Wageningen UR, 2011). 


\section{Scenario's en indeling ecotopen}

\subsection{Scenario's}

In samenspraak met betrokkenen (workshop 24 oktober 2016, Bijlage C) zijn vijf scenario's gedefinieerd om nader te onderzoeken. Deze staan weergegeven in Tabel 2. Daarnaast staan in Figuur 6 en Figuur 7 de scenario's verbeeld in dwarsdoorsneden waarbij de ecotopen staan aangegeven en waterstanden t.o.v. NAP. De ecotopen worden nader toegelicht in paragraaf 3.2. Het werd van belang geacht om aan te sluiten op het voorkeursalternatief van de Rijksstructuurvisie (RSV), maar daarnaast ook breder de gevolgen van peilbeheer en een kleinere getijslag te onderzoeken en een doorkijk naar de langetermijngevolgen te geven en de gevolgen van zeespiegelstijging inzichtelijk te maken. Hieronder worden de huidige situatie (scenario 0 ) en de vijf scenario's toegelicht:

0. Huidige situatie met het huidige peilbeheer: Dit scenario is nodig als referentiesituatie. Uitwisseling van water met de Noordzee gebeurt via de Brouwerssluis. Vanaf 2017 is ook de verbinding met de Oosterschelde via de Flakkeese Spuisluis opengesteld. De spuisluis heeft een daggemiddelde capaciteit van ongeveer $70-80 \mathrm{~m}^{3} \mathrm{~s}^{-1}$. Het middenpeil van $-0,20 \mathrm{~m}$ NAP wordt in het broedseizoen (periode april-juli) met $6 \mathrm{~cm}$ verlaagd zodat broedvogels op de kale delen kunnen broeden. In de periode september-februari wordt in drie perioden van drie weken gestuurd op een middenpeil NAP $-0,16 \mathrm{~m}$.

1. RSV: Het voorkeursalternatief binnen de RSV stelt een getijslag van $50 \mathrm{~cm}$ voor op het Grevelingenmeer via een doorlaat in het noordelijke deel van de Brouwersdam. In dit scenario wordt een middenpeil van -0,20 m NAP het hele jaar door gehandhaafd.

2. RSV-Springtij: Omdat binnen het voorkeursalternatief nog geen beslissing is genomen over het al dan niet toelaten van een gedempt springtij, worden de effecten van een marge van $10 \mathrm{~cm}$ springtij-doodtij meegenomen. Springtij treedt ongeveer twee keer per maand op vlak na volle en nieuwe maan. Dit betekent dat een strook van $+5 \mathrm{~cm}$ langs de gemiddelde hoogwaterlijn eens in de twee weken onderloopt. Ook in dit scenario wordt het huidige winterpeil van $-0,20$ $m$ NAP het hele jaar door gehandhaafd.

3. Getij30: Een wens vanuit de betrokkenen is om de gevolgen van een kleinere getijslag van 30 $\mathrm{cm}$ uit te werken, om inzicht te krijgen in de gevolgen voor zuurstofloosheid op de bodem en de terrestrische natuurwaarden (incl. broedgebied voor vogels) in vergelijking met scenario's 1 en 2 . Dit scenario betreft een getijslag van $30 \mathrm{~cm}$ met een vast middenpeil $-0,20 \mathrm{~m}$ NAP.

4. RSV-Peilbeheer: Betrokkenen benadrukken het nut van het huidige beheer met een lager zomerpeil t.b.v. de (kale grond) broedvogels. Dit scenario onderzoekt de gevolgen van het RSVvoorkeursalternatief met een variabel peilbeheer, $m . n$. een $30 \mathrm{~cm}$ hoger winterpeil dan in de huidige situatie ( $+10 \mathrm{~cm}$ NAP i.p.v. $-20 \mathrm{~cm}$ NAP) en een zomerpeil van -0,26 m NAP.

5. RSV-Zeespiegelstijging: Dit scenario geeft een doorkijk naar 2050 waarbij uitgegaan is van maximale zeespiegelstijging van $40 \mathrm{~cm}$ (KNMI WH klimaatscenario) en uitgaande van het RSVvoorkeursalternatief met $50 \mathrm{~cm}$ getijslag. Hierbij is dus uitgegaan van een vast middenpeil van $+20 \mathrm{~cm}$ NAP (40 cm hoger dan het huidige winterpeil) om inzicht te geven in de gevolgen van zeespiegelstijging voor het voorkomen van ecotopen.

Tabel 2. Te onderzoeken scenario's van verschillend waterbeheer die in overleg met betrokkenen zijn bepaald.

\begin{tabular}{|c|c|c|c|c|c|c|}
\hline Scenario & $\begin{array}{l}\text { O. } \\
\text { Huidige } \\
\text { situatie }\end{array}$ & $\begin{array}{l}1 . \\
\text { RSV }\end{array}$ & $\begin{array}{l}2 . \\
\text { RSV-springtij }\end{array}$ & $\begin{array}{l}3 . \\
\text { Getij-30 }\end{array}$ & $\begin{array}{l}4 . \\
\text { RSV-Peilbeheer }\end{array}$ & $\begin{array}{l}\text {. } \\
\text { RSV-Zeespiegel- } \\
\text { Stijging }\end{array}$ \\
\hline Getijslag [m] & Microgetij & 0,50 & 0,50 & 0,30 & 0,50 & 0,50 \\
\hline Peil [m NAP] & $\begin{array}{l}-0,20\left(" \text { winter }^{\prime \prime 1}\right) \\
-0,26(\text { "zomer"2) }\end{array}$ & $-0,20$ & $-0,20$ & $-0,20$ & $\begin{array}{l}+0,10 \text { ("winter") } \\
-0,26 \text { ("zomer") }\end{array}$ & $+0,20$ \\
\hline $\begin{array}{l}\text { Springtij/ doodtij } \\
\text { cyclus }[\mathrm{m}]\end{array}$ & 0 & 0 & $+/-0,05^{3}$ & 0 & 0 & 0 \\
\hline
\end{tabular}

${ }^{1}$ Het middenpeil wordt zoveel mogelijk gehouden op NAP $-0,20 \mathrm{~m}$ (fluctuerend tussen max. NAP $-0,10 \mathrm{~m}$ en min. NAP $-0,30$

$\mathrm{m}$; in de periode sep-feb wordt in drie perioden van drie weken gestuurd op een middenpeil van NAP -0,16 m.

${ }^{2}$ tijdens het broedseizoen ( 1 april -15 juli) wordt gestuurd op een middenpeil van NAP -0,26 m.

${ }^{3}$ Toelaten getijfluctuatie volledige springtij-doodtij cyclus 


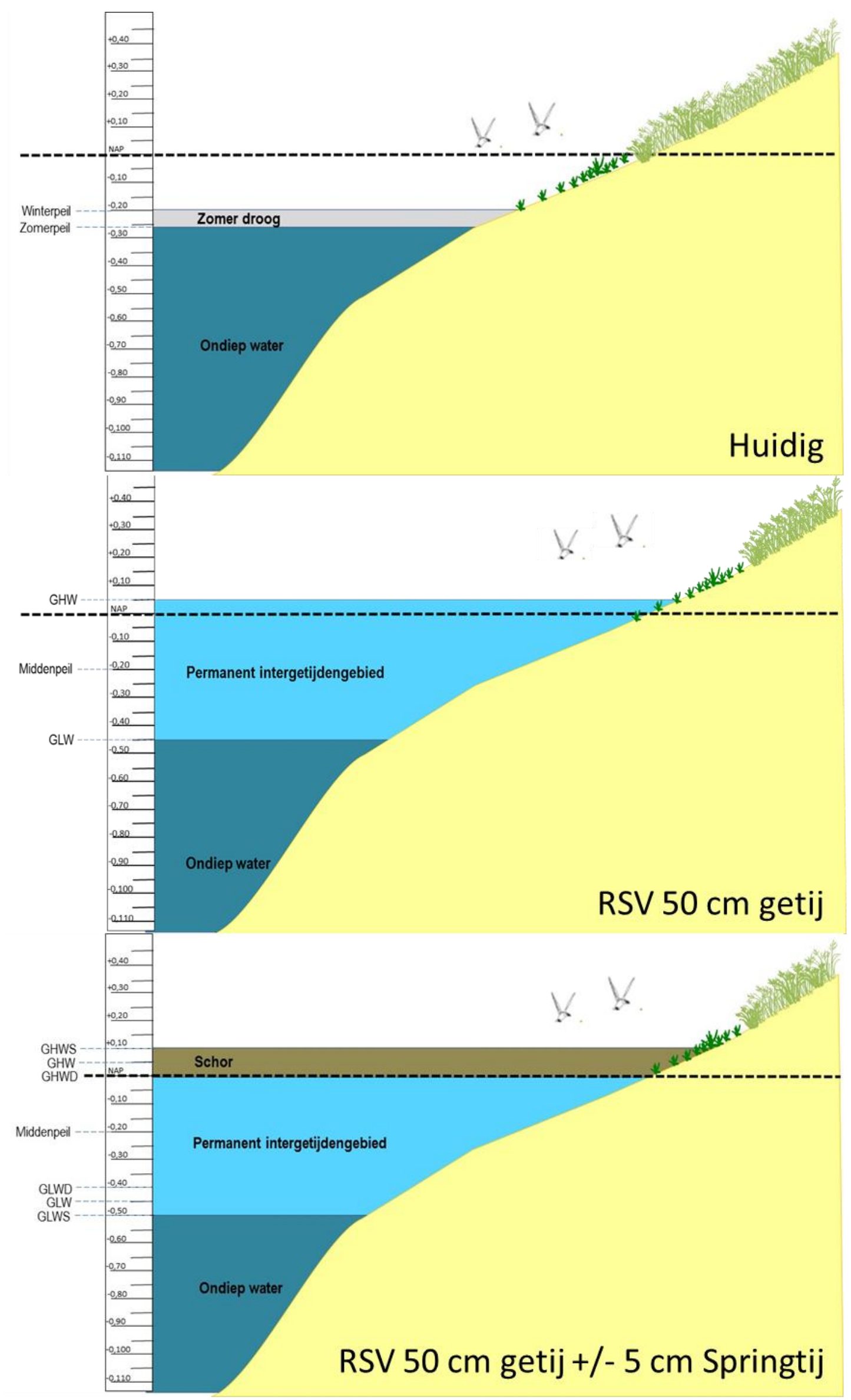

Figuur 6. Scenario's 0,1 en 2 verbeeld in dwarsdoorsneden met daarin de ecotopen (bv. ondiep water, permanent intergetijdengebied, etc.) en waterstanden t.o.v. NAP aangegeven. Het betreft de scenario's: 0 . Huidig (boven), 1. RSV (midden) en 2. RSV-Springtij (onder). Zie ook Tabel 2. 


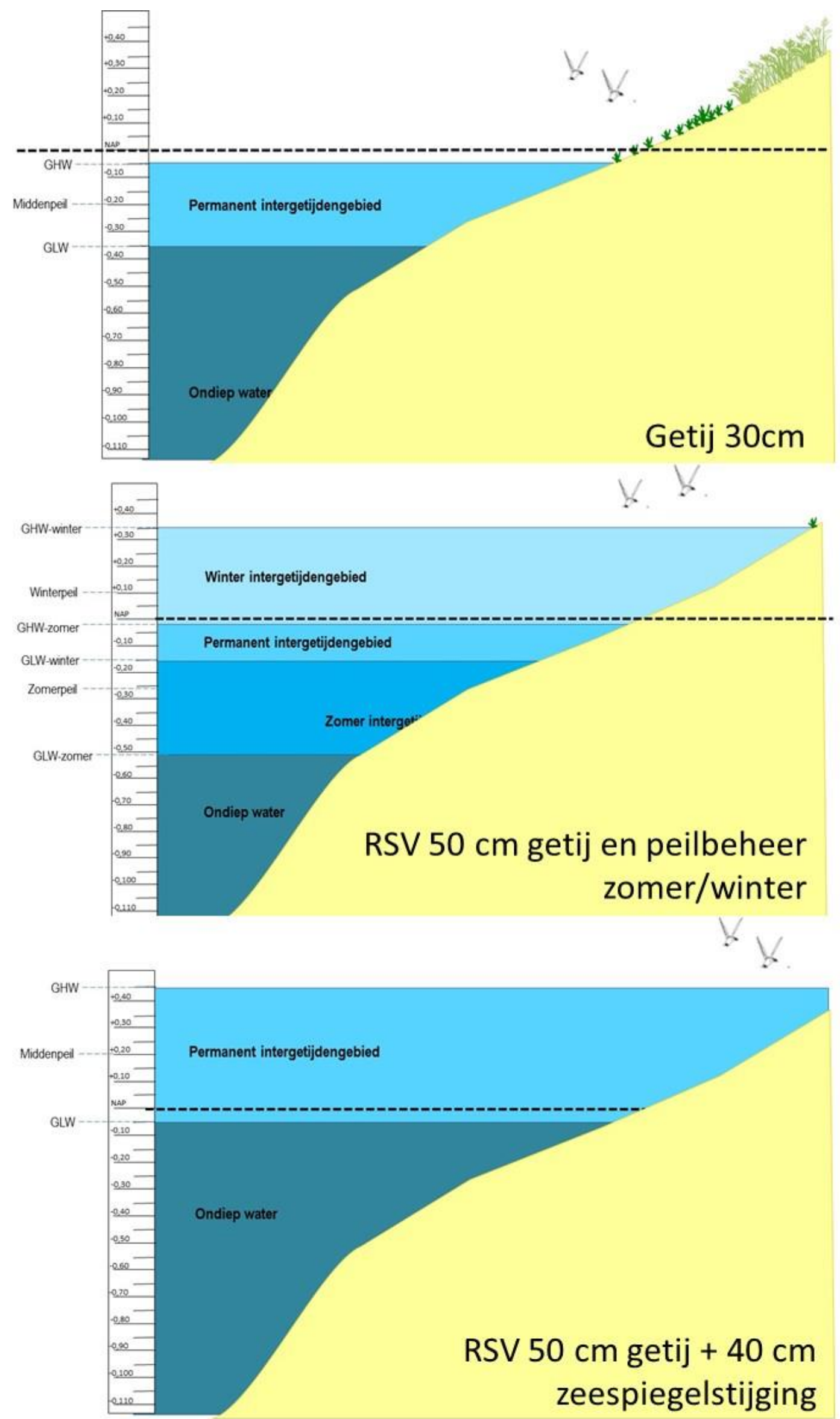

Figuur 7. Scenario's verbeeld in dwarsdoorsneden met daarin de ecotopen (ondiep water, permanent intergetijdengebied, etc.) en waterstanden t.o.v. NAP aangegeven. Het betreft de scenario's: 3 'Getij30' (boven), 4 'RSV-Peilbeheer' (midden) en 5 'RSV-zeespiegelstijging' (onder). Zie ook Tabel 2. 


\subsection{Indeling in ecotopen}

Zowel fysisch-chemische ontwikkelingen (bv. waterdynamiek, nutriënten, etc.) als ecologische ontwikkelingen (ontstaan van habitats en levensgemeenschappen) zullen in elke scenario anders zijn. Om de verwachte ecologische ontwikkeling in ieder scenario te kunnen bepalen is een indeling in ecotopen gehanteerd. Een ecotoop kan beschouwd worden als een duidelijke herkenbaar onderdeel van een ecosysteem dat daardoor gemakkelijk in kaart gebracht kan worden (Dankers et al. 2012).

In Tabel 3 staan de in deze studie gehanteerde ecotopen weergegeven en in welk scenario deze ecotopen voorkomen. Gekozen is voor een relatief grove indeling waarin de ecotopen op basis van de hoogteligging zijn onderverdeeld in droogvallende delen ('terrestrisch'), intergetijdengebieden, ondiep water en diep water. Ook staan subtypen aangegeven. In Tabel 4 staan de begrenzingen van de ecotopen en subtypen aangegeven. Het doel van deze indeling is om voor ieder scenario de ecologische veranderingen in een kaartbeeld te kunnen uitwerken als basis voor de discussie over welke natuurwaarden verwacht kunnen worden. In deze studie is ervoor gekozen om hard substraat ecotoop dat voorkomt op de dijken en oeverbeschermingen buiten beschouwing te laten. Voor het opstellen van de indeling en de (ecologische) beschrijving hieronder van de ecotopen is primair gebruik gemaakt van het Ecotopenstelsel voor de Zoute Wateren (Bouma et al. 2005). Daarnaast zijn ook andere bronnen benut: een eerdere scenariostudie voor de Zuidwestelijke Delta (Ysebaert et al. 2013a; Ysebaert et al. 2016), Natura 2000-habitattypen profieldocumenten (http://www.synbiosys.alterra.nl/natura2000) en andere literatuur (Ysebaert et al. 2000; Vandenbussche et al. 2002; Holzhauer et al. 2011). De ecotopen en subtypen worden een voor een beschreven. De ecotopen intergetijdengebieden, ondiep water en diep water betreffen allen zoute ecotopen met een saliniteit $>18$ psu.

Tabel 3. Een overzicht van de indeling in zoute ecotopen en subtypen en in welke scenario's ze voorkomen.

\begin{tabular}{|c|c|c|c|c|c|c|c|c|}
\hline & Ecotoop & Sub-typen & $\begin{array}{l}\frac{0}{\sigma} \\
\frac{0}{3} \\
\frac{1}{x}\end{array}$ & 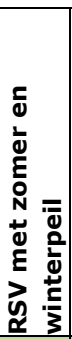 & 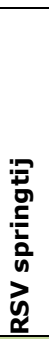 & 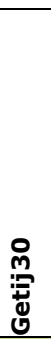 & 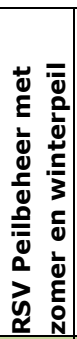 & 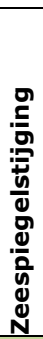 \\
\hline \multirow{9}{*}{ 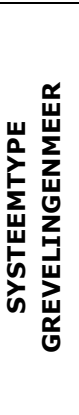 } & Terrestrisch & Terrestrisch zoet & $\checkmark$ & $\checkmark$ & $\checkmark$ & $\checkmark$ & $\checkmark$ & $\checkmark$ \\
\hline & & Terrestrisch met zoute invloed & $\sqrt{ }$ & $\sqrt{ }$ & $\sqrt{ }$ & $\sqrt{ }$ & $\sqrt{ }$ & $\sqrt{ }$ \\
\hline & Intergetijdengebied & Schor (springtijzone) & & & $\sqrt{ }$ & & & \\
\hline & & Zomer intergetijdengebied (zomerpeil) & & & & & $\sqrt{ }$ & \\
\hline & & Permanent intergetijdengebied & & $\checkmark$ & $\checkmark$ & $\sqrt{ }$ & $\checkmark$ & $\checkmark$ \\
\hline & & Winter intergetijdengebied (winterpeil) & & & & & $\sqrt{ }$ & \\
\hline & Ondiep water & & $\sqrt{ }$ & $\sqrt{ }$ & $\sqrt{ }$ & $\sqrt{ }$ & $\sqrt{ }$ & $\checkmark$ \\
\hline & & Zomer droog & $\sqrt{ }$ & & & & & \\
\hline & Diep water & & $\sqrt{ }$ & $\sqrt{ }$ & $\sqrt{ }$ & $\sqrt{ }$ & $\sqrt{ }$ & $\sqrt{ }$ \\
\hline
\end{tabular}


Tabel 4. Begrenzing van ecotopen en subtypen (boven) en de modelmatige begrenzing in percentielen van het totaal aan optredende waterstanden die gebruikt is voor de kaarten. Afkortingen: GHW = Gemiddeld Hoog Water, GLW = Gemiddeld Laag Water, GHWS = Gemiddeld Hoog Water Springtij, GLWS = Gemiddeld Laagwater Springtij, GHWD = Gemiddeld Hoog Water Doodtij, GLWD = Gemiddeld Laag Water Doodtij.

\begin{tabular}{|c|c|c|c|c|c|}
\hline \multirow[b]{2}{*}{ Ecotoop } & \multirow[b]{2}{*}{ Sub-typen } & \multicolumn{2}{|l|}{ Stagnant } & \multicolumn{2}{|l|}{ Getijdengebied } \\
\hline & & Bovengrens & Ondergrens & Bovengrens & Ondergrens \\
\hline \multicolumn{2}{|c|}{ Terrestrisch } & & $>$ gem. zomerpeil & & $\begin{array}{l}>\text { GHW / } \\
\text { GHWS }\end{array}$ \\
\hline & Terrestrisch zoet & & $\begin{array}{l}\text { Zie p.16 (o.b.v. } \\
\text { vegetatiekartering) }\end{array}$ & & \\
\hline & $\begin{array}{l}\text { Terrestrisch met } \\
\text { zout invloed }\end{array}$ & $\begin{array}{l}\text { Zie p.16 (o.b.v. } \\
\text { vegetatiekartering) }\end{array}$ & >gem. zomerpeil & $\begin{array}{l}\text { Zie p.16 (o.b.v. } \\
\text { vegetatiekartering) }\end{array}$ & $\begin{array}{l}>\text { GHW / } \\
\text { GHWS }\end{array}$ \\
\hline \multicolumn{2}{|c|}{ Intergetijdengebied } & & & $<\mathrm{GHW} / \mathrm{GHWD}$ & $\begin{array}{l}>\text { GLW / } \\
\text { GLWS }\end{array}$ \\
\hline & $\begin{array}{l}\text { Schorzone (springtij } \\
\text { zone) }\end{array}$ & & & GHWS & GHWD \\
\hline & $\begin{array}{l}\text { Zomer } \\
\text { intergetijdengebied }\end{array}$ & & & $\begin{array}{l}\text { <GHW t.o.v. } \\
\text { zomerpeil }\end{array}$ & $\begin{array}{l}\text { >GLW t.o.v. } \\
\text { zomerpeil }\end{array}$ \\
\hline & $\begin{array}{l}\text { Permanent } \\
\text { intergetijdengebied }\end{array}$ & & & $<\mathrm{GHW}$ & $>\mathrm{GLW}$ \\
\hline & $\begin{array}{l}\text { Winter } \\
\text { intergetijdengebied }\end{array}$ & & & $\begin{array}{l}<\text { GHW t.o.v. } \\
\text { winterpeil }\end{array}$ & $\begin{array}{l}\text { >GLW t.o.v. } \\
\text { winterpeil }\end{array}$ \\
\hline \multicolumn{2}{|c|}{ Ondiep water } & & & GLWS & $\begin{array}{l}-5 m \text { t.o.v. } \\
\text { GLWD }\end{array}$ \\
\hline & Zomer droog & & & <gem. winterpeil & $\begin{array}{l}\text { >gem. } \\
\text { zomerpeil }\end{array}$ \\
\hline \multicolumn{2}{|c|}{ Diep water } & & & $<-5 m$ t.o.v. GLWD & \\
\hline
\end{tabular}

\begin{tabular}{|l|l|}
\hline Waterstand & Percentiel \\
\hline Incidentele overspoeling & $>99-$ max. waterstand \\
\hline GHWS & 99 \\
\hline GHW & 95 \\
\hline GHWD & 93 \\
\hline GLWD & 7 \\
\hline GLW & 5 \\
\hline GLWS & 1 \\
\hline
\end{tabular}

\section{Diep water}

Dit zoute ecotoop betreft de van het Grevelingenmeer met een waterdiepte van $>5 \mathrm{~m} \mathrm{t.o.v.} \mathrm{Gemiddeld}$ Laag Water Springtij en een saliniteit van $>18$. Het betreft voornamelijk het diepere deel van de aflopende oevers, de geulen en diepe putten. Waterdynamiek en daarmee samenhangende (transport)processen zijn één van de bepalende factoren voor het voorkomen van soorten in dit ecotoop. Daarom wordt hieronder een korte beschrijving gegeven van stagnant diep water (huidige situatie) en een situatie met getij (potentiele toekomstige situatie).

Stagnant (deels overgenomen uit Bouma et al. 2005): Vanwege het stagnante zoute water is het ecotoop specifiek voor het Grevelingenmeer. De waterdynamiek in een stagnant Grevelingenmeer is te vergelijken met dat van een meer. In het voorjaar en in de zomer treedt vaak temperatuurstratificatie op. De bovenste waterlaag is warmer en daarmee lichter dan de onderste koudere waterlaag. Vanwege de slechte menging van beide waterlagen kan na verloop van tijd in de onderste waterlaag zuurstofloosheid optreden, beginnend in de diepe putten bij Scharendijke en Den Osse, met massale 
sterfte van bodemorganismen tot gevolg. Tijdens of vlak na het optreden van zuurstofloosheid komt er maar beperkt tot geen bodemleven voor in dit ecotoop.

In het zachte substraat van het diep water ecotoop zijn over het hele Grevelingenmeer bekeken de wormen het belangrijkst qua dichtheden en de mollusken (weekdieren) qua biomassa. Veel voorkomende wormen zijn Oligochaeten, de slangpier (Capitella capitata) en de zeeduizendpoot (Alitta virens). Van de weekdieren is het muiltje (Crepidula fornicata) het belangrijkst, zowel qua aantallen als biomassa. Daarnaast is de Japanse oester (Crassostrea gigas) (eco-element) sterk in opkomst en daarmee concurrent geworden van de platte oester (Ostrea edulis) (uit Hoeksema, 2002). De meest voorkomende visetende vogels in het Grevelingenmeer zijn de middelste zaagbek (Mergus serrator), fuut (Podiceps cristatus) en geoorde fuut (Podiceps nigricollis).

Getij: In een (gedempt) getijdensituatie vormen de geulen in het Grevelingenmeer een belangrijk onderdeel van het hydro-morfologisch systeem. Geulen worden van nature gekenmerkt door een grote dynamiek. Het bodemleven is vaak dan ook eerder beperkt, bv. zoals waargenomen wordt in de Westerschelde, maar dit is afhankelijk van de mate van getijdendynamiek. Bij een waterbeheer met een gedempt getij zullen in dit ecotoop (de geulen en diepere delen van het Grevelingenmeer $>5 \mathrm{~m} \mathrm{t.o.v}$. GLWS) de stroomsnelheden op de meeste plaatsen relatief laag zijn. In het ZES ecotopenstelsel wordt de grens tussen hoogdynamisch en laagdynamisch ecotoop gelegd bij een stroomsnelheid van $0.8 \mathrm{~m} / \mathrm{s}$ (Bouma et al. 2005). De verwachting is dat deze stroomsnelheden zelden zullen overschreden worden bij een gedempt getij in het Grevelingenmeer. Enkel lokaal (bv. bij de inlaten) kunnen de stroomsnelheden hoger zijn. De verwachting is dan ook dat de bodemdiergemeenschappen in het diepe water bij gedempt getij kenmerken zullen vertonen die horen bij laagdynamische omstandigheden, zoals die bv. ook in de Oosterschelde voorkomen. De soortenrijkdom zal niet zeer hoog zijn en kan verschillen naar gelang de bodem fijnzandig is dan wel slibrijk. Volgens Bouma et al. (2005) zijn kenmerkende soorten bodemdieren in deze laagdynamische milieus wormen als de zeeduizendpoot (Nereis sp.), zandzager (Nephtys sp.), draadworm (Heteromastus filiformis), amphipoden als de slijkgarnaal (Corophium sp.) en het kniksprietkreeftje (Bathyporeia sp.) en schelpdieren als het nonnetje (Limecola balthica) en de kokkel (Cerastoderma edule). Voorbeelden van vissoorten zijn schol (Pleuronectus platessa), tong (Solea solea), botervis (Pholis gunnellus), grondels (Gobiidae) slakdolf (Liparis liparis) en diklipharder (Chelon labrosus).

Net als in de Oosterschelde kunnen in het diepe water rifvormende soorten voorkomen zoals de Japanse oester (Crassostrea gigas). In het Grevelingenmeer komt ook de platte oester (Ostrea edulis) voor. Deze riffen vormen hotspots van biodiversiteit waarbij vaak ook heel wat exoten voorkomen.

Visetende vogels die bij dit ecotoop horen zijn bijvoorbeeld visdief (Sterna hirundo), grote stern (Sterna sandvicensis), dwergstern (Sterna albifrons), aalscholver (Phalacrocorax carbo), fuut (Podiceps cristatus) en middelste zaagbek (Mergus serrator). Verder horen ook de zeezoogdieren gewone zeehond (Phoca vitulina) en de bruinvis (Phocoena phocoena) bij dit ecotoop. Deze soorten dienen als indicatie. Welke soorten in werkelijkheid voorkomen in dit ecotoop type is afhankelijk van hydromorfologische factoren als stroomsnelheid en bodemsedimenten, waterkwaliteit (bijvoorbeeld zuurstofconcentratie) maar ook connectiviteit (i.v.m. vissen en zeezoogdieren). Daarnaast hangt het voorkomen van vogelpopulaties samen met vele andere factoren zoals migratie en de (nabije) aanwezigheid van andere habitats zoals broedgebied of hoogwatervluchtplaatsen. Geulen fungeren tevens als belangrijke transportroute voor allerlei organismen (o.a. transport van larven) en een migratieroute voor verschillende vissoorten en zeezoogdieren.

\section{Ondiep water}

Dit ecotoop betreft de ondiepe delen van het Grevelingenmeer vanaf de waterlijn/Gemiddeld Laag Water (Springtij) tot een waterdiepte van 5 meter en een saliniteit van $>18$. Ondiepwatergebieden worden verondersteld gebieden te zijn met een grote potentiële natuurwaarde, vooral als kinderkamer en opgroeigebied van vissen en kreeftachtigen. Net als bij het ecotoop 'diep water' wordt een beschrijving gegeven van soortengemeenschappen in een stagnante en een getijdensituatie.

Stagnant (deels overgenomen uit Bouma et al. 2005): Vanwege het stagnante zoute water is het ecotoop specifiek voor het Grevelingenmeer. Stagnante systemen hebben geen of een zeer beperkte getijdewerking; dit wil niet zeggen dat er geen waterpeilschommelingen kunnen optreden. In ondiep water is niet snel sprake van zuurstofloosheid. In het zachte substraat zijn over het hele Grevelingenmeer bekeken de wormen het belangrijkst qua dichtheden en de mollusken (weekdieren) 
qua biomassa. Veel voorkomende wormen zijn oligochaeten, de slangpier (Capitella capitata) en de zeeduizendpoot (Alitta virens). Van de weekdieren is het muiltje (Crepidula fornicata) het belangrijkst, zowel qua aantallen als biomassa. Daarnaast is tegenwoordig de Japanse Oester (Crassostrea gigas) (eco-element) sterk in opkomst, en tegenwoordig in grote aantallen vertegenwoordigd, en daarmee concurrent geworden van de platte Oester (Ostrea edulis). In het ecotoop kunnen velden van groot zeegras (Zostera marina) voorkomen (eco-element), die leefmogelijkheden bieden voor allerlei kleine vissen en planteneters. Momenteel zijn echter in het Grevelingenmeer geen zeegrasvelden meer aanwezig maar wordt wel op pilotschaal geëxperimenteerd met herintroductie. De meest voorkomende visetende vogels in het Grevelingenmeer zijn de middelste zaagbek (Mergus serrator), fuut (Podiceps cristatus) en geoorde fuut (Podiceps nigricollis).

Getij: De getijbeweging, en met name de heersende stroomsnelheden zullen in belangrijke mate het voorkomen van bodemleven bepalen. Bij een waterbeheer met een gedempt getij zullen in dit ecotoop, net als in het diepe water, de stroomsnelheden op de meeste plaatsen relatief laag zijn. In het ZESecotopenstelsel wordt de grens tussen hoogdynamisch en laagdynamisch ecotoop gelegd bij een stroomsnelheid van $0.8 \mathrm{~m} / \mathrm{s}$ (Bouma et al. 2005). De verwachting is dat deze stroomsnelheden zelden zullen overschreden worden bij een gedempt getij in het Grevelingenmeer. Enkel lokaal (bv. bij de inlaten) kunnen de stroomsnelheden hoger zijn. De verwachting is dan ook dat de bodemdiergemeenschappen in het ondiepe water bij gedempt getij kenmerken zullen vertonen die horen bij laagdynamische omstandigheden, zoals die bv. ook in de Oosterschelde voorkomen. De soortenrijkdom zal naar verwachting hoger zijn dan in het diepe water, en kan verschillen naar gelang de bodem fijnzandig is dan wel slibrijk. De bodemdiersoorten in ondiepe sublitorale gebieden vertonen op de meeste plaatsen een vrij grote overeenkomst met de bodemdiersoorten in het nabij gelegen litoraal (intergetijdengebied). De aantallen organismen, de biomassa en de soortendiversiteit zijn vrij hoog, maar over het algemeen lager dan in het litoraal. Volgens Bouma et al. (2005) zijn kenmerkende soorten bodemdieren in deze laagdynamische milieus wormen als de zeeduizendpoot (Nereis sp.), zandzager (Nephtys sp.), draadworm (Heteromastus filiformis), wadpier (Arenicola marina), en amphipoden als de slijkgarnaal (Corophium sp.), het kniksprietkreeftje (Bathyporeia sp.), de gewone garnaal (Crangon crangon) en de strandkrab (Carcinus maenas), en schelpdieren als het Nonnetje (Limecola balthica) en de kokkel (Cerastoderma edule). Ook de schelpkokerworm (Lanice conchilega) kan in dit ecotoop voorkomen. Voorbeelden van vissoorten zijn schol (Pleuronectus platessa), tong (Solea solea), botervis (Pholis gunnellus), grondels (Gobiidae), slakdolf (Liparis liparis) en diklipharder (Chelon labrosus).

Net als in de Oosterschelde kunnen in het ondiepe water rifvormende soorten voorkomen zoals de Japanse oester (Crassostrea gigas) (exoot). In het Grevelingenmeer komt ook de platte oester (Ostrea edulis) voor. Deze riffen vormen hotspots van biodiversiteit waarbij vaak ook heel wat exoten voorkomen.

Visetende vogels die bij dit ecotoop horen zijn bijvoorbeeld visdief (Sterna hirundo), grote stern (Sterna sandvicensis), dwergstern (Sterna albifrons), aalscholver (Phalacrocorax carbo), fuut (Podiceps cristatus), brilduiker (Bucephala clangula) en eidereend (Somateria mollissima). Verder hoort ook de gewone zeehond (Phoca vitulina) bij dit ecotoop en kan groot zeegras (Zostera marina) lokaal potentieel voorkomen. Net als bij het diep water ecotoop dienen deze soorten als indicatie. Welke soorten in werkelijkheid voorkomen in dit ecotoop typen is afhankelijk van hydromorfologische factoren als stroomsnelheid en bodemsedimenten, waterkwaliteit (bijvoorbeeld zuurstofconcentratie) maar ook connectiviteit (i.v.m. vissen en zeezoogdieren). Daarnaast hangt het voorkomen van vogelpopulaties samen met vele andere factoren zoals migratie en de (nabije) aanwezigheid van andere habitats zoals broedgebied of hoogwatervluchtplaatsen.

\section{Zomer droog (huidige situatie)}

Het sub-ecotoop 'Zomer droog' (Tabel 3) in het Grevelingenmeer betreft de in de huidige situatie in de zomer droogvallende zone omdat vanaf april het winterpeil van -0,20m NAP wordt verlaagd naar -0,26m NAP ten behoeve van broedvogels. Dit betreft dus een enigszins onnatuurlijk ecotoop dat in de zomer droog staat door verlaging van de waterstand en in de winter (vanaf september) weer tot het ondiep water ecotoop behoort. De beschrijving van dit ecotoop is onder meer gebaseerd op literatuur van het Veerse Meer (Werkgroep Peilbesluit Veerse Meer, 2007) waar sinds de afsluiting in 1960 een halfjaarlijks alternerend peilbeheer wordt toegepast (NB: hier wordt een hoog zomerpeil en een laag winterpeil toegepast t.b.v. gunstige grondwaterstanden voor de landbouw). 
Als het peil in het voorjaar verlaagd wordt zal de zone tussen -0,20 en -0,26m NAP droogvallen. De bodem met daarin de aanwezige bodemdieren van ondiep water valt droog en wordt blootgesteld aan de in het voorjaar toenemende temperaturen. Als gevolg van uitdroging zullen deze organismen afsterven. Mobiele dieren zoals vissen en kreeftachtigen zullen zich verplaatsen naar diepere delen. In deze oeverzone kan zich dus geen stabiele flora en fauna ontwikkelen (Craeymeersch \& De Vries 2007). Steltlopers profiteren tijdelijk van de jaarlijkse peilverlaging omdat ze ongestoord kunnen foerageren op het bodemleven. De periode dat dit kan is beperkt omdat het bodemleven snel zal afsterven door uitdroging. Dit ecotoop is van groot belang voor vogels die broeden op kale of schaars begroeide gronden. Doordat het ecotoop in de winter permanent onder water staat vindt geen of nauwelijks vegetatieontwikkeling plaats en ontstaat in de zomer een zone met een overwegend kale bodem. Verschillende soorten kustbroedvogels kunnen hiervan profiteren: bontbekplevier (Charadrius hiaticula), dwergstern (Sternula albifrons), grote stern (Thalasseus sandvicensis), kluut (Recurvirostra avosetta), strandplevier (Charadrius alexandrinus) en visdief (Sterna hirundo) (Rijkswaterstaat 2015).

\section{Intergetijdengebied}

Het ecotoop 'intergetijdengebied' betreft de intergetijdenzone die bij vloed overstroomt met zout water (saliniteit $>18$ ) en bij eb droogvalt. Intergetijdengebieden zijn doorgaans hoogproductieve zones met een zeer rijk bodemdieren- en plantenleven en fungeren ook als rui-, rust- en foerageergebied voor vogels, foerageergebied voor (jonge) vis en hyperbenthos (o.a. kinderkamerfunctie) en rust- en zoogplaats voor zeezoogdieren. Een van de sturende variabelen voor het voorkomen van bodemleven (het benthos) in dit ecotoop is de getijbeweging. De getijbeweging bepaalt niet alleen de droogvalduur, maar ook de lokale stroomsnelheden. Stroomsnelheden beïnvloeden de morfologische ontwikkeling (sedimentatie- en erosieprocessen) op verschillende tijd- en ruimteschalen, maar beïnvloeden ook rechtstreeks de leefomstandigheden voor soorten. Ook golven spelen hierbij een rol en kunnen een belangrijke rol spelen in de sedimentdynamiek en daar bijhorende sedimentatie- en erosieprocessen. Omdat stroomsnelheden/golfwerking in getijdengebieden nooit constant zijn en in de ruimte sterk kunnen variëren, ontstaan gradiënten en een mozaïek aan habitats. Op grond van aan- of afwezigheid van bodemvormen (morfologie), sedimentsamenstelling en een koppeling met optredende stroomsnelheden/golven, kan een onderscheid gemaakt worden tussen hoog- en laagdynamische habitats of ecotopen. Hoogdynamische habitats kenmerken zich door relatief hoge stroomsnelheden, vaak duidelijk zichtbare bodemvormen (ribbels en megaribbels) en een (instabiele) bodem die vooral uit relatief grof zand bestaat. Het bodemleven in zulke hoogdynamische gebieden is meestal gering, en weinig soorten zijn aangepast aan dit dynamische milieu. In laagdynamische habitats stroomt het water met beperkte stroomsnelheden. De laagdynamische habitats zijn relatief vlak en bieden de mogelijkheid om fijn sediment af te zetten, inclusief slib. De omwoeling van de bodem door fysische processen is beperkt. Laagdynamische habitats vormen een aantrekkelijke habitat voor het bodemleven (bodemdieren en algen). Het bodemleven vormt dan weer een belangrijke voedselbron voor allerlei soorten vogels en vissen. In het onderscheid tussen hoog- en laagdynamische habitats zit dus een biologisch waardeoordeel vervat. Bij een waterbeheer met een gedempt getij zullen de stroomsnelheden in het intergetijdengebied van het Grevelingenmeer, net als in het ondiepe en diepe water, op de meeste plaatsen relatief laag zijn. In het ZES ecotopenstelsel wordt de grens tussen hoogdynamisch en laagdynamisch ecotoop gelegd bij een stroomsnelheid van $0.8 \mathrm{~m} / \mathrm{s}$ (Bouma et al. 2005). De verwachting is dat deze stroomsnelheden niet zullen overschreden worden bij een gedempt getij in het Grevelingenmeer en dat het intergetijdengebied laagdynamisch van karakter zal zijn. Golfwerking kan wel op meer geëxponeerde gebieden zorgen voor een (tijdelijk) hogere dynamiek en bv. slib uitspoelen. Hier zullen de oeververdedigingen ook een belangrijke rol spelen. Voorbeelden van soorten bodemdieren die bij dit (laagdynamische, zout) ecotoop horen (naar Bouma et al. 2005) zijn onder meer kokkel (Cerastoderma edule), nonnetje (Limecola balthica), strandgaper (Mya arenaria), wadslakje (Peringia ulvae), slijkgarnaal (Corophium sp.), kniksprietkreeftje (Bathyporeia sp.), gewone garnaal (Crangon crangon), wadpier (Arenicola marina), wapenworm (Scoloplos armiger), zandkokerworm (Pygospio elegans), zandzager (Nephtys hombergii) en schelpkokerworm (Lanice conchilega). Mosselbanken (Mytilus edulis) en riffen van de Japanse oester (Crassostrea gigas) vormen kenmerkende ecoelementen in dit ecotoop. Voorbeelden van soorten vissen zijn bot (Platichthys flesus), schol (Pleuronectus platessa), tong (Solea solea), zeebaars (Dicentrarchus labrax) en diklipharder (Chelon labrosus). Bodemdieretende vogels die bij dit ecotoop horen zijn bijvoorbeeld scholekster (Haematopus ostralegus), wulp (Numenius arquatus), bonte strandloper (Calidris alpina), kanoet (Calidris canutus), 
rosse grutto (Limosa lapponica), zilverplevier (Pluvialis squatarola) en bergeend (Tadorna tadorna). Ook soorten als rotgans (Branta bernicla) en wintertaling (Anas crecca) komen in dit ecotoop voor. Verder hoort ook de gewone zeehond (Phoca vitulina) bij dit ecotoop (i.v.m ligplaatsen) en kan groot zeegras (Zostera marina), klein zeegras (Zostera noltii) en snavelruppia (Ruppia maritima) potentieel voorkomen. Net als bij het diep en ondiep water ecotoop dienen deze soorten als indicatie. Welke soorten in werkelijkheid voorkomen in dit ecotoop is afhankelijk van hydromorfologische factoren als stroomsnelheid en bodemsedimenten en droogvalduur. Daarnaast hangt het voorkomen van vogelpopulaties samen met vele andere factoren zoals migratie en de (nabije) aanwezigheid van andere habitats zoals broedgebied of hoogwatervluchtplaatsen.

\section{Zomer- en winterintergetijdengebied (scenario RSV Peilbeheer)}

De subecotopen 'Zomer intergetijdengebied' en 'Winter intergetijdengebied' (Tabel 3) ontstaan in het scenario 'RSV Peilbeheer' met $50 \mathrm{~cm}$ getijslag en een zomerpeil van -0,26m NAP en een winterpeil van $+0,10$ m NAP. Het zomer intergetijdengebied ontstaat in het scenario RSV Peilbeheer wanneer in het voorjaar (maart) het middenpeil naar beneden wordt bijgesteld op -0,26m NAP. Dit ecotoop wordt begrensd door Gemiddeld Hoog Water van -0,01m NAP en Gemiddeld Laag Water van -0,51m NAP. Deze zone zal als gevolg van het peilbeheer dus tussen maart en september behoren tot het ecotoop 'intergetijdengebied' en in de winter tot 'ondiep water'. De voorkomende processen en levensgemeenschappen zullen sterke gelijkenissen vertonen met het ecotoop 'intergetijdengebied'. In de zomer zullen vogels bij laag water op de droogvallende delen kunnen foerageren, in de winter staat het gebied permanent onder water en zullen, afhankelijk van de lokale waterdiepte, enkel steltlopers met lange poten eventueel hier voedsel kunnen vinden (bv. wulp). Voor soorten als kleine zilverreiger vormt het gebied naar verwachting wel een interessant foerageergebied, alsmede voor bepaalde grondeleenden.

Het winter intergetijdengebied ontstaat in het scenario RSV Peilbeheer wanneer in het najaar (eind september) het middenpeil wordt opgehoogd tot $+0,10 \mathrm{~m}$ NAP. Dit ecotoop wordt begrensd door Gemiddeld Hoog Water van -0,15m NAP en Gemiddeld Laag Water van -0,35m NAP. Deze zone zal als gevolg van het peilbeheer van oktober tot februari behoren tot het ecotoop 'intergetijdengebied' en in de zomer tot 'terrestrisch met zoutinvloed'. Omdat deze zone in de zomer droog staat zullen geen stabiele bodemdiergemeenschappen kunnen ontwikkelen. In de winterperiode is deze zone onderhevig aan getij-invloed, maar naar verwachting zullen zich maar een beperkt aantal bodemdiersoorten vestigen in deze zone. Dit zal in hoofdzaak gebeuren via migratie van organismen vanuit het intergetijdengebied en ondiepe water. In de zomerperiode zullen de bodemdieren doodgaan en voor een zeer korte periode een voedselbron vormen voor vogels.

\section{Schor (Scenario RSV Springtij)}

Het ecotoop 'schor' betreft de zone hoog in het intergetijdengebied tussen Gemiddeld Hoog Water Doodtij en Gemiddeld Hoog Water Springtij en komt voor in het scenario RSV Springtij. Van nature ontstaan schorren wanneer slikken zo hoog komen te liggen dat ze niet meer dagelijks overstroomd worden, waardoor periodiek minder dynamische omstandigheden heersen, en (permanente) plantengroei mogelijk wordt. De belangrijkste ecologische factoren die de aanwezigheid van flora en de successie op schorren bepalen zijn zoutgehalte, overstromingsdynamiek (frequentie, -duur en -hoogte), sediment input, bodemtextuur en de daaraan gekoppelde zuurstofhuishouding, verzanding, stikstofgehalte in de bodem en huidig en historisch beheer. Schorren zijn dus door getijden beïnvloede, niet permanent onder water staande, doorgaans slibrijke milieus. Hiermee onderscheiden ze zich van zilte graslanden die niet onder invloed staan van getij. Voor Natura 2000 wordt het volgende onderscheid gemaakt voor H1330 (Atlantische schorren): Subtype A. Schorren en zilte graslanden (buitendijks); Subtype B. Schorren en zilte graslanden (binnendijks). In de huidige situatie komt enkel subtype B voor. Bij introductie van springtij zal ook subtype A ontstaan.

Zonatie is een zeer belangrijk en opvallend kenmerk van natuurlijke schorvegetaties (Beeftink, 1965) en geeft een goed beeld van de successie in de tijd. De benedengrens wordt aangegeven door een kaal oppervlak van het type slikken en platen. Algemeen kan gesteld worden dat het kale slik wordt ingenomen door pioniervegetaties en dat deze opgevolgd worden door ruigere vegetaties en dat zich uiteindelijk de climaxvegetatie vormt van strandkweekgemeenschappen (in het geval van zoute schorren). Kenmerkende soorten zijn bijvoorbeeld zeekraal (Salicornia sp.), Engels slijkgras (Spartina 
anglica), zeealsem (Artemisia maritima), gewone zoutmelde (Atriplex portulacoides), lamsoor (Limonium vulgare), zeeaster (Aster tripolium), schorrezoutgras (Triglochin maritimum), rood zwenkgras (Festuca rubra) en strandkweek (Elymus athericus). Daarnaast zijn schorren van betekenis voor verschillende soorten (broed)vogels en enkele zoogdieren (Anonymus, 2009). Momenteel komen geen schorren voor in het gebied, maar een vergelijkende vegetatie wordt aangetroffen in smalle zones langs de oevers van het meer, binnen het subtype ecotoop 'terrestrisch met zoutinvloed'.

\section{Terrestrisch}

Het ecotoop 'terrestrisch' vertegenwoordigt de niet of zelden overstroomde delen op de oevers en eilanden die zich boven Gemiddeld Hoog Water / Gemiddeld Hoog Water Springtij bevinden. Er wordt onderscheid gemaakt in de subtypen 'terrestrisch met zoutinvloed' en 'terrestrisch zoet'. Beide subecotopen omvatten een brede variatie aan vegetaties, die naast de zoutinvloed, bepaald worden door de bodem, vochttoestand en het gevoerde beheer. De bodem bestaat voor het grootste deel uit (fijn) zand met lokaal aanwezige 'sliblenzen', maar op de voormalige schorren (de meest oostelijke delen van de Slikken van Flakkee) is de bodem veel kleiiger en voedselrijker. Na sluiting van het Grevelingenmeer zijn de oevers en platen drooggevallen en begroeid geraakt. Geleidelijk zijn de hoger gelegen delen ontzilt en is in de bodem een zoetwaterbel tot ontwikkeling gekomen waardoor zoetminnende vegetaties voorkomen, vooral op plekken waar regenwater stagneert of afstroomt over of net onder het maaiveld. Richting de laaggelegen delen komt een brakke overgangsvegetatie voor met steeds meer zoutminnende soorten.

\section{Terrestrisch met zoutinvloed}

Dit sub-ecotoop betreft de zone vanaf de waterlijn (hoogwater) tot aan de grens met zoetminnende vegetatie. De vegetatie staat onder invloed van zout water door opwaaiing en zoutspray en wordt gekenmerkt door een zonering van open kale tot schaars begroeide delen naar een meer gesloten vegetatie met zoutminnende soorten en overgangsvegetaties met meer brakke soorten. De hiernavolgende beschrijving is gebaseerd op Bouma et al. (2005) en Janssen \& Schaminée (2009).

De oevers zelf en oude kreken zijn begroeid met een pioniervegetatie van halofyten, zoals kortarige zeekraal (Salicornia europaea) en klein schorrenkruid (Suaeda maritima), terwijl iets hogere delen meer zijn dichtgegroeid met zoutminnende soorten als gewoon kweldergras (Puccinellia maritima), melkkruid (Glaux maritima) en zilte rus (Juncus gerardii). Naarmate de ontzilting toeneemt wordt de vegetatie soortenrijker. In deze brakke graslanden vinden we onder meer soorten als hertshoornweegbree (Plantago coronopus), fraai duizendguldenkruid (Centaurium pulchellum), zilverschoon (Potentilla anserina) en smalle rolklaver (Lotus glaber). De bovengrens van het ecotoop ligt op het niveau waar het aandeel zoutplanten in de bedekking minder is dan 5\%. De Zeekraal-begroeiingen kwalificeren als habitattypen 'Zilte pionierbegroeiingen' (H1310) en de zoute en brakke graslanden als habitattype 'Atlantische schorren' (H1330). Deze begroeiingen komen zowel op beheerde als niet beheerde delen voor, maar waar begraasd en gemaaid wordt, weten de begroeiingen zich veel langer te handhaven, omdat er minder bodemvorming en ophoging plaatsvindt. Op de niet-beheerde delen betreft het slechts een kleine zone die geleidelijk terrein verliest door ontzilting van de bodem.

Het deel van de oevers van het Grevelingenmeer dat nog onder regelmatige invloed staat van het zout water is kaal, of spaarzaam begroeid met zeekraal (Salicornia spp.) en/of schorrenkruid (Suaeda maritima). Op de slikkige randen van het meer broeden bontbekplevieren (Charadrius hiaticula) en kluten (Recurvirostra avosetta). De grote kale vlaktes zoals deze voorkomen op de Slikken van Flakkee zijn belangrijke broedgebieden voor strandplevieren (Charadrius alexandrinus) en bontbekplevieren (Charadrius hiaticula).

Op de begroeide oevers van het Grevelingenmeer overwinteren brandganzen (Branta leucopsis), kolganzen (Anser albifrons), rotganzen (Branta bernicla) en smienten (Anas penelope). De Hompelvoet is een belangrijk broedgebied voor grote sterns (Sterna sandvicensis).

De beweide gebieden zijn geschikt als broedgebied voor weidevogels zoals de kievit (Vanellus vanellus) en tureluur (Tringa totanus).

\section{Terrestrisch zoet}

De beschrijving van dit sub-ecotoop is gebaseerd op de gebiedsbeschrijving voor het Grevelingenmeer uit Janssen \& Schaminée (2009), die ook op de Natura 2000-website staat (www.synbiosys.alterra.nl/natura2000). Het ecotoop 'terrestrisch zoet' bestaat uit een variatie aan begroeiingen, waarvan een deel hoge waardering heeft vanuit Natura 2000. 
$\mathrm{Na}$ de afsluiting kwam op de voormalige schorren en drooggevallen platen een vegetatiesuccessie op gang die tot op de dag van vandaag nog gaande is. De oude schorren groeiden in vrij korte tijd dicht met ruigtekruiden en grassen. Hierin is weinig ruimte voor vestiging van struiken en bomen, en tot op heden is de vegetatie daarom vooral een dichte ruigte, gedomineerd door o.a. duinriet (Calamagrostis epigejos), jacobskruiskruid (Jacobaea vulgaris), grote brandnetel (Urtica dioica), riet (Phragmites australis), akkerdistel (Cirsium arvense), dauwbraam (Rubus caesius) en kropaar (Dactylis glomerata), met op slechts enkele plekjes struweel en wat bomen. Dit zijn de hoogste delen van het gebied, die vooral aanwezig zijn op de slikken van Flakkee Noord. De vegetatie kwalificeert hier niet als Natura 2000-habitattype.

Op de voormalige zandplaten treedt successie op van een zoutvegetatie naar zoete begroeiingen, waarbij het van groot belang is of er beheerd wordt (maaien, begrazing) of niet. Op niet beheerde delen vindt een ontwikkeling plaats naar struweel (met duindoorn Hippophae rhamnoides, meidoorn Crataegus monogyna, vlier Sambucus nigra) en bos (met name boswilg Salix caprea, andere wilgensoorten en berken Betula spec.). Waar duindoorn domineert is sprake van het habitattype 'Duindoornstruwelen' ( $\mathrm{H} 2160)$. Op sommige plekken ontstaat een ruigte met duinriet, of op nattere delen een rietmoeras of brakke ruigte. Waar in dit laatste vegetatie heemst (Althaea officinalis) aanwezig is, is sprake van het habitattype 'Ruigte en zomen' (H6430); dit type is zover bekend beperkt tot de noordelijke delen van de Slikken van Flakkee.

Op delen waar beheersmaatregelen worden uitgevoerd zijn uitgestrekte brakke en zoete natte graslanden ontstaan. Dankzij de kalkrijkdom van het onderliggende zand zijn deze zeer soortenrijk en herbergen ze veel bedreigde plantensoorten, waaronder parnassia (Parnassia palustris), fraai duizendguldenkruid (Centaurium pulchellum), waterpunge (Samolus valerandi), kleverige ogentroost (Euphrasia stricta), bonte paardenstaart (Equisetum variegatum), rondbladig wintergroen (Pyrola rotundifolia), herfstschroeforchis (Spiranthes spiralis), groenknolorchis (Liparis loeselii), en diverse andere orchideeën. De kalkrijke vormen worden gerekend tot het habitattype 'Vochtige duinvalleien' (H2190B) en - de iets oudere, ontkalkte stadia, met doorgaans veel kruipwilg (Salix repens) - tot habitattype 'Kruipwilgstruwelen' (H2170). Type H2190B vormt een in heel Europa sterk bedreigd habitattype, waarvoor Nederland in internationaal opzicht belangrijk is, dankzij de diverse herstelmaatregelen in de duinstreek én dankzij de ontwikkeling van het type op dit soort drooggevallen platen in de Zuidwestelijke Delta. De Grevelingen herbergt één van de grootste oppervlaktes H2190B in Nederland, met naar schatting zo'n 250 tot 300 hectare. Dit is te danken aan een combinatie van (1) het voorhanden zijn van een groot oppervlakte relatief zandig, voedselarm en kalkrijk substraat op de drooggevallen oevers en eilanden in het gebied, en (2) het intensieve maai- en begrazingsbeheer dat plaatsvindt, met name op de Hompelvoet, Veermansplaat en Slikken Flakkee Zuid. Gepaard met dit habitattype H2190 gaat het voorkomen van verreweg de grootste populatie van de orchidee groenknolorchis, die beschermd is onder de Habitatrichtlijn. Het merendeel van de populatie bevindt zich op de Veermansplaat (de Kraker 2017). Een kleine oppervlakte in het gebied, op de Hompelvoet (droge duingraslanden), wordt ingenomen door droge graslanden die kwalificeren als habitattype 2130 'Duingraslanden'. Bijzondere soorten daar zijn onder meer harlekijn (Anacamptis morio) en maanvaren (Botrichium lunaria). 


\section{Huidige situatie}

\subsection{Gebiedsbeschrijving}

Het Grevelingenmeer is in de periode 1965 -1970 ontstaan door de aanleg van de Grevelingendam (1965) en de Brouwersdam (1970). Er is hiermee een gebied afgesloten dat in de loop van vele eeuwen onder invloed van menselijke ingrepen was ontstaan en dat zich samen met het Krammer-Volkerak had ontwikkeld tot een onderdeel van het estuarium van Rijn en Maas (en vroeger ook Schelde) in de Zuidwestelijke Delta. In 1965 werd door de aanleg van de Grevelingendam het getijvolume sterk verminderd. In 1970 verdween door het sluiten van de Brouwersdam (gereed in 1971) het getij volledig en ontstond een zoutwatermeer van 14.000 ha (waarvan 11.000 ha open water) met de bathymetrie van een estuarium met aanwezigheid van diepe geulen en ondiepe wateren. De voormalige slikken en platen vielen droog en daardoor ontstonden eilanden zoals de Veermansplaat en Hompelvoet en flauw aflopende oevers langs de randen zoals de Slikken van Flakkee (Figuur 8).

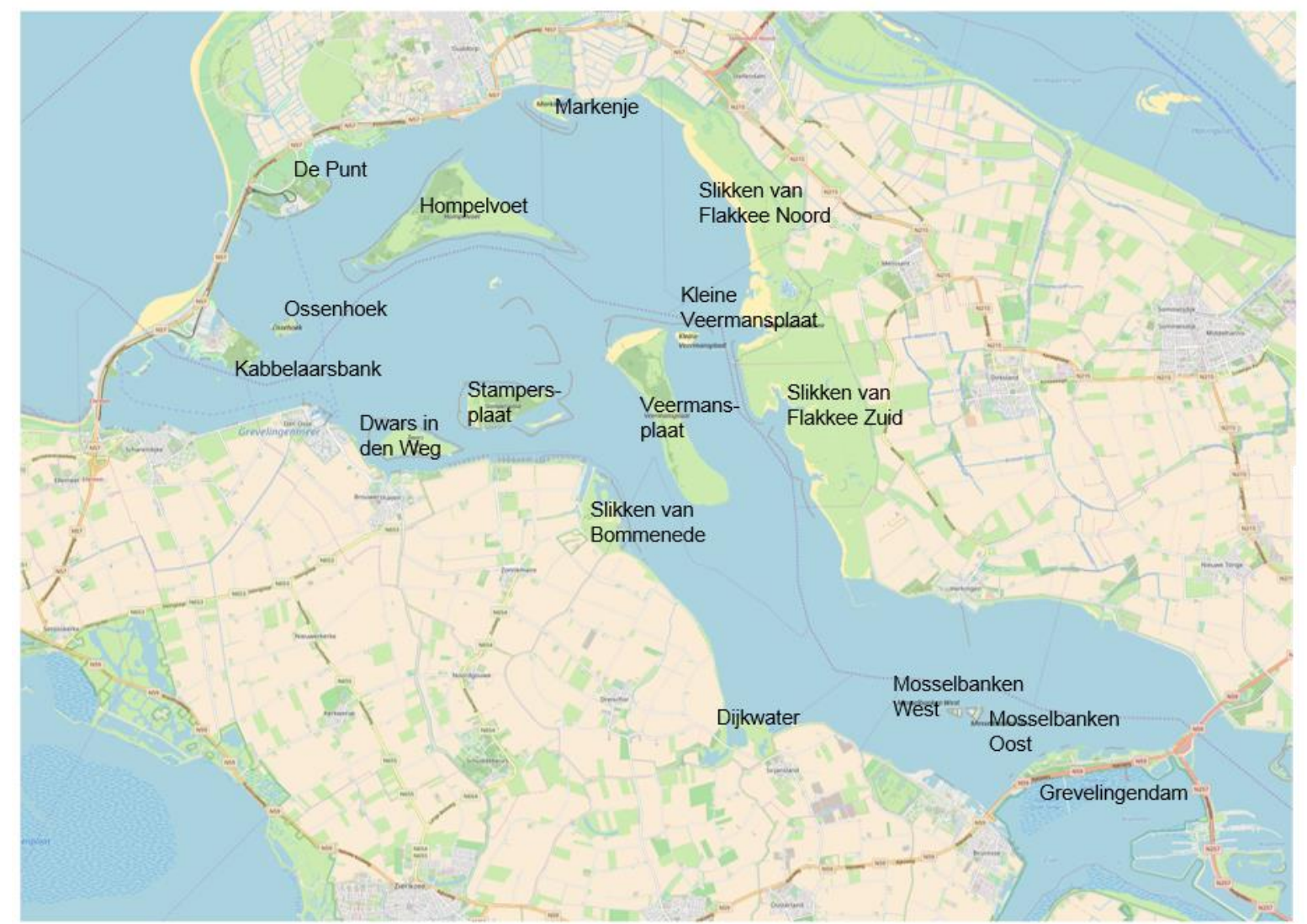

Figuur 8. Het Grevelingenmeer met de belangrijkste gebieden.

\section{Waterhuishouding}

In 1978 is de Brouwerssluis aangelegd die daggemiddeld circa 100 tot $125 \mathrm{~m}^{3} / \mathrm{s}$ uitwisseling met de Noordzee realiseert door middel van de getijstroming. De sluis werd in het begin enkel in de periode december-september opengezet. Vanaf 1999 is er een permanente uitwisseling, met een incidentele sluiting ten behoeve van de visserij (30-dagen-regeling). In het oosten van het meer is in de winter van 2017 de Flakkeese Spuisluis, een doorlaatmiddel in de Grevelingendam, in werking gesteld die zorgt voor een verbinding met de Oosterschelde. Het debiet vanuit de Oosterschelde naar het Grevelingenmeer bedraagt ongeveer $110 \mathrm{~m}^{3} / \mathrm{s}$ en van het Grevelingenmeer naar de Oosterschelde circa $65-70 \mathrm{~m}^{3} / \mathrm{s}$ (dit heeft te maken met een hoger peil in de Oosterschelde). Het middenpeil van $-0,20 \mathrm{~m}$ NAP wordt in het broedseizoen (periode april-juli) met $6 \mathrm{~cm}$ verlaagd zodat broedvogels op de kale delen kunnen broeden. In de periode september-februari wordt in drie perioden van drie weken gestuurd op een middenpeil NAP $-0,16$ m. In werkelijkheid vertoont het waterniveau schommelingen. Het peil mag 
gedurende het hele jaar fluctueren tussen maximaal $-0,10 \mathrm{~m}$ NAP en minimaal $-0,30 \mathrm{~m}$ NAP, maar daarbij wordt het zomer- en winterpeil wel zo goed als mogelijk nagestreefd (Rijkswaterstaat 2013).

Peilvariatie wordt ook veroorzaakt door windopzet of -verlaging. Windopzet is afhankelijk van de windsnelheid, de waterdiepte, de strijklengte (dat wil zeggen de afstand die wind ongehinderd over een wateroppervlak waait) en een empirische constante die representeert hoeveel de wind aangrijpt op het wateroppervlak ('wind drag'). Gebruik makend van standaardwaarden voor de empirische constante en gebaseerd op twee verschillende formules geeft Tabel 5 een indicatie van het effect van windopzet. Bij harde storm is een windopzet van enkele tientallen $\mathrm{cm}$ tot een halve meter mogelijk. Tijdens de expertsessie werd bevestigd dat de Slikken van Flakkee bij storm volledig onder water kunnen staan.

Tabel 5. Indicatie van windopzet als functie van strijklengte en windsnelheid.

\begin{tabular}{|l|l|l|l|}
\hline Strijklengte $(\mathrm{km})$ & Windsnelheid $(\mathrm{m} / \mathrm{s})$ & Windkracht (Bofor) & Windopzet $(\mathrm{m})$ \\
\hline \multirow{5}{*}{10} & 10 & 5 & $0,03-0,05$ \\
\cline { 2 - 4 } & 15 & 7 & $0,08-0,12$ \\
\cline { 2 - 4 } & 20 & 8 & $0,14-0,21$ \\
\cline { 2 - 4 } & 30 & 11 & $0,31-0,48$ \\
\hline \multirow{5}{*}{15} & 10 & 5 & $0,05-0,08$ \\
\cline { 2 - 4 } & 15 & 7 & $0,12-0,18$ \\
\cline { 2 - 4 } & 20 & 8 & $0,21-0,32$ \\
\cline { 2 - 4 } & 30 & 11 & $0,47-0,72$ \\
\hline
\end{tabular}

Er lozen vijf poldergemalen (Battenoord, Dreischor, Herkingen, de Kille en Den Osse) op het Grevelingenmeer die in beheer zijn bij Waterschap Scheldestromen en Waterschap Hollandse Delta. Het gemiddelde debiet betreft circa $1-1,5 \mathrm{~m}^{3} / \mathrm{s}$ overslag van brak polderwater met een zoutgehalte van circa 2-6 psu (Spiteri \& Nolte 2010). Het jaargemiddelde zoutgehalte in het Grevelingenmeer varieert tussen ca. 27,7 en 31,6 psu gemeten bij Dreischor (Wetsteyn 2010) (zeewater = circa 35 psu).

\section{Bathymetrie en sedimentkarakteristieken}

De bathymetrie heeft betrekking op het verloop van de waterbodem. De bathymetrie van het Grevelingenmeer is te omschrijven als een geulenstelsel met enkele diepe putten, dat door een ondiep gebied (ca. $1 \mathrm{~m}$ diep) met eilanden (de voormalige platen) loopt. De diepe putten variëren in diepte van circa $20 \mathrm{~m}$ tot maximaal ca. $45 \mathrm{~m}$ (Spiteri \& Nolte 2010).

Het Grevelingenmeer kent een typische estuariene textuurgradiënt van grofzandige, slibarme bodems in het westen naar meer fijnzandige, silbrijke bodems in het oosten (Van de Haterd et al. 2010). Een dergelijke gradiënt is ook aanwezig op de platen (eilanden) in het midden naar de randen (Nienhuis 1985). Dit beeld wordt bevestigd door sedimentmetingen die werden uitgevoerd in het kader van MWTL. Deze metingen tonen een kleinere mediane korrelgrootte in het oostelijk deel dan in het westelijk deel (Leewis et al. 2015). De eilanden bevatten over het algemeen minder dan 1,5\% lutum (kleiarm zand). Op de Slikken van Flakkee en aan de oostkant van Hompelvoet en de Veermansplaat is het lutumgehalte 1,5-3\%. Op de Slikken van Bommenede en Slik voor Dijkwater is het lutumgehalte 1,5-8\% (Van de Haterd et al. 2010). De typische estuariene textuurgradiënt geldt echter alleen nog voor de ondiepe delen, de diepere delen zijn, na het verdwijnen van de getijstroom, inmiddels overal bedekt met een laag slib.

$\mathrm{Na}$ de afsluiting van het Grevelingenmeer verdween de getijstroom en daarmee viel de opbouwende werking weg waardoor in de ondiepe zones alleen nog de afbrekende werking van de golven overbleef. Daarom zijn na afsluiting delen van de oevers en eilanden voorzien van een oeververdediging om de voortschrijdende erosie tegen te gaan. In het meer zijn vier types oevers te onderscheiden; (1) onverdedigd, (2) met een directe verdediging, (3) met een indirecte verdediging, of (4) met een combinatie van beide (Figuur 9). Het Grevelingenmeer heeft ca $60 \mathrm{~km}$ oever (gebieden zonder hoofdfunctie recreatie, De Jong en Van Maldegem, 2010), waarvan ca 14,2 km niet is verdedigd en de overige delen zijn verdedigd. De recreatiegebieden zijn als regel direct verdedigd of gecombineerd verdedigd. Tabel 6 geeft de verdeling over de diverse types oeververdediging voor de gebieden die geen recreatiefunctie hebben (De Jong \& Van Maldegem 2010). 


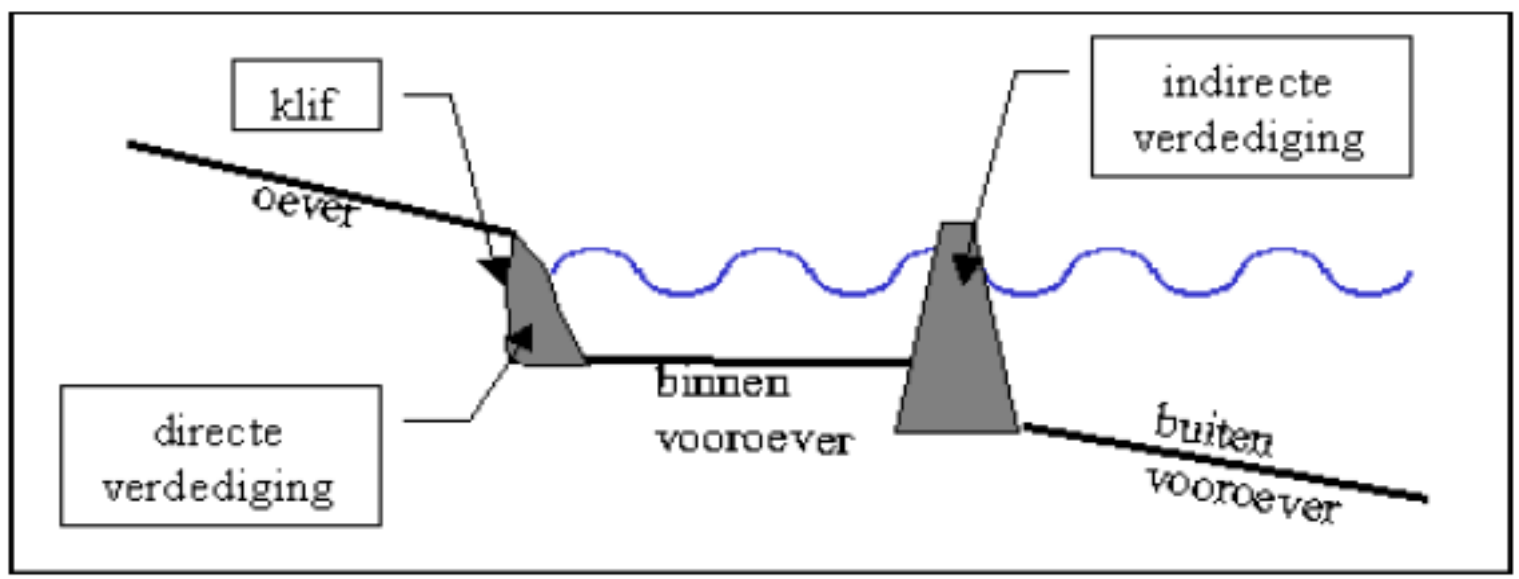

Figuur 9. Verschillende typen oeververdediging: in het Grevelingenmeer wordt zowel directe als indirecte verdediging en een combinatie van beide toegepast (De Jong \& Van Maldegem 2010).

Tabel 6. Overzicht van de oeververdedigingen (in $\mathrm{m}$ ) in 2010 voor de gebieden zonder hoofdfunctie recreatie. Dit vertegenwoordigt ca $80 \%$ van de totale oeverlengte in het Grevelingenmeer (De Jong \& Van Maldegem 2010).

\begin{tabular}{|c|c|c|c|c|c|}
\hline type verdediging & direct & combinatie & indirect & niet & opmerking \\
\hline Hompelvoet & 500 & 7250 & 0 & 2200 & \\
\hline Veermansplaat & 9500 & 750 & 1150 & 0 & \\
\hline Stampersplaat & 0 & 6200 & 0 & 0 & waarvan $1800 \mathrm{~K}$ Stpl \\
\hline Dwars in de Weg & 0 & 3800 & 0 & 0 & \\
\hline Slikken van Flakkee-N & 0 & 0 & 0 & 6200 & \\
\hline Slikken van Flakkee-Z & 0 & 900 & 2800 & 2000 & \\
\hline Slik van Bommenede & 0 & 0 & 1600 & 0 & recreatiedeel niet \\
\hline Slik van Sirjansland & 0 & 0 & 0 & 1000 & hoge schelpenrand \\
\hline Markenje & 0 & 0 & 950 & 1200 & \\
\hline Punt-O ( Springersgors) & 0 & 0 & 0 & 1600 & \\
\hline totaal per type & 10000 & 18900 & 6500 & 14200 & \\
\hline totaal direct en combinatie & \multicolumn{2}{|c|}{28900} & & & \\
\hline totaal indirect en niet verdedigd & & & \multicolumn{2}{|c|}{20700} & \\
\hline totaal alle typen & \multicolumn{4}{|c|}{49600} & \\
\hline
\end{tabular}

Waterkwaliteit en zuurstofhuishouding

Door de beperkte dynamiek van het water treedt in het Grevelingenmeer temperatuurstratificatie op waarbij in de zomer in de onderste waterlaag zuurstofloosheid op kan treden. Dit is een belangrijk zorgpunt voor de ecologie omdat dit proces kan leiden tot afsterven van bodemleven en daarmee ook verdere gevolgen heeft voor het systeem (bv. verminderd voedsel voor vissen en vogels). Het optreden van zuurstofloosheid wordt goed beschreven door een studie van Bouma et al. (2008) en de daarin vermelde referenties:

"Het zuurstofgehalte van het water in het Grevelingenmeer is een veel besproken aspect van de waterkwaliteit en één van de belangrijkste zorgpunten van de huidige situatie. De bovenste waterlaag is het hele jaar gemiddeld genomen ongeveer verzadigd met zuurstof, hoewel de verzadiging in de zomer soms tot $80 \%$ daalt. In en op de bodem kunnen het hele jaar door zuurstofloze condities heersen. Gedurende het voorjaar en de zomer is de zuurstofloosheid in en nabij de bodem het meest nadrukkelijk aanwezig. Twee processen, die voor het eerst beschreven zijn door Waardenburg in 1976 en door Vink \& De Vos (1980) in de begin jaren tachtig, liggen hieraan ten grondslag:

1. Stratificatie van de waterkolom komt doordat waterlagen verschillende dichtheden hebben als gevolg van verschillen in temperatuur en/of saliniteit. In het voorjaar verwarmt de zon de bovenste waterlaag op die hierdoor lichter wordt en gaat drijven op de koudere, zwaardere waterlaag daaronder. Er vindt nu vrijwel geen uitwisseling van zuurstof meer plaats tussen de bovenste en onderste waterlaag, waardoor zuurstof in de onderste waterlaag uitgeput kan raken en er zuurstofloze condities ontstaan. 
2. Zuurstof consumerende (afbraak) processen in en nabij de bodem. Dood organisch materiaal uit de waterkolom, zoals bijvoorbeeld algen, zinkt naar de bodem en wordt daar afgebroken door allerlei (micro)organismen. Deze afbraak is een zuurstof consumerend proces. Bij grote hoeveelheden dood organisch materiaal op de bodem of in de waterkolom onttrekt dit proces zoveel zuurstof aan het water, dat er zuurstofloze condities ontstaan. Vooral dit tweede proces leidt ieder jaar tot zuurstofloosheid in en nabij de bodem, ook in minder warme jaren.

In de praktijk versterken de twee bovenstaande processen elkaar. Als gevolg van de zuurstofloze condities in de bodem worden er op de bodem van het Grevelingenmeer tot op een diepte van 5 meter witte matten aangetroffen die veroorzaakt worden door verschillende soorten van de zwavelbacterie (Beggiatoa spp.). Deze bacterie oxideert zwavel als energiebron met behulp van zuurstof en leeft daarom op het grensvlak van zuurstof en sulfide. Meestal bevindt dit grensvlak zich in de bodem en sulfide oxiderende bacteriën, zoals Beggiatoa spp., komen dan ook in groten getale voor in mariene kustsedimenten zonder witte matten te vormen. Pas wanneer het grensvlak van zuurstof en sulfide boven of op het sediment komt te liggen, dus bij zeer lage zuurstofconcentraties in de waterkolom, worden de bacteriën zichtbaar in de vorm van witte matten."

Nolte en Basch (2011) schrijven het voorkomen en de verspreiding van de witte matten toe aan ophoping van organisch materiaal en zuurstofarme condities die als gevolg van zout- en/of temperatuurstratificatie en de geringe dynamiek van het Grevelingenmeer aanwezig zijn. Uit de monitoring door Bureau Waardenburg komt naar voren dat de weersomstandigheden (temperatuur en wind, soms speelt zout stratificatie een rol) zeer bepalend zijn voor het voorkomen van (Beggiatoa) bacteriematten. De matten ontwikkelen niet als het volledig zuurstofloos is want de bacterie heeft zuurstof nodig. De matten komen alleen voor op het moment dat het bodemoppervlak zuurstofloos begint te worden, of als de zuurstofconcentratie in het water net weer gaat stijgen. Ze komen dus voor onder zuurstofarme condities maar niet onder zuurstofloze condities. Het gaat dus meestal om een tijdelijke situatie waarin zuurstofconcentratie een rol speelt. De bedekking kan weer afnemen afhankelijk van de weersomstandigheden, bijv. na een storm kan weer menging optreden. De bacteriematten zijn dus een indicatie voor zuurstofarme condities.

Onderzoek wijst uit dat (op basis van visuele inspectie) massale sterfte van het bodemleven optreedt op de plekken waar de witte bacteriematten ontwikkelen en dat dit gerelateerd is aan lage zuurstofconcentraties (Lengkeek et al. 2010; Lengkeek \& Bouma 2011; Didderen et al. 2013). Hoge bedekkingen zijn met name aangetroffen in het oostelijk deel bij de Bocht van St Jacob (langs de Grevelingendam) en het Springersdiep (noordelijk deel Brouwersdam). Dit is mogelijk te verklaren door het bezinken van zeesla of andere wieren/algen waardoor een extra zuurstofvraag ontstaat en de zuurstofconcentratie in het water daalt (persoonlijke communicatie Wouter Lengkeek). Aanvoer van organisch materiaal vanuit de Noordzee draagt mogelijk ook bij aan de zuurstofvraag in het Grevelingenmeer (Seitaj 2016). Het bedekkingspercentage van de bacteriematten neemt toe met toenemende waterdiepte. Vanaf 4 meter diepte zijn er hoge bedekkingen $(>50 \%)$ met witte bacteriematten waargenomen (Didderen et al. 2013). Na een hittegolf in de zomer die een week duurt kan massale sterfte van het bodemleven optreden (persoonlijke communicatie Wouter Lengkeek). In een studie door Nolte en Basch (2011) wordt geconcludeerd dat frequent terugkerende zuurstofarme periodes ervoor zorgen dat het bodemleven geen kans krijgt om zich volledig te herstellen, als het eenmaal door een zuurstofarme periode is verdwenen. Na een zuurstofarme periode vindt juist wel snel kolonisatie door Beggiatoa plaats. Een vertragend effect treedt mogelijk op doordat bodemleven moeilijker terugkeert in een door Beggiatoa zuurstofloos geworden sediment. Het is mogelijk dat de afwezigheid van bodemdieren de aanwezigheid van Beggiatoa juist versterkt, omdat bioturbatie van de bodem ontbreekt. Voor de ophoping van organisch materiaal in de diepere delen is geen aanwijzing gevonden en deze lijkt dan ook hooguit van secundair belang.

Zuurstoftekort in het bodemwater heeft grote gevolgen voor het functioneren van het ecosysteem vanwege de grote effecten op de biogeochemische cycli en de impact op de overlevingskansen en het gedrag van mariene organismen (Seitaj 2016). 


\subsection{Economische activiteiten en recreatie}

De Grevelingen kent een groot aantal functies en economische activiteiten. De belangrijkste zijn beroepsvisserij, natuur en recreatie (recreatievaart, zwemwater, strand- en oeverrecreatie, (onder)watersport, kitesurfen en sportvisserij). Verder wordt het gebied gebruikt als waterkering, voor waterafvoer en door de beroepsscheepvaart.

In de Grevelingen is sprake van zonering van het gebruik in ruimte en tijd. Het aanwijzen van specifieke rustplekken en niet of minder toegankelijk maken van gebieden (zonering) is belangrijk voor het garanderen van voldoende rust voor verschillende habitattypen en soorten van de instandhoudingsdoelen, zonder dat ingrijpende belemmeringen aan recreatieve activiteiten worden gelegd (Ministerie van Infrastructuur en Milieu, 2016).

De Grevelingen trekt naar schatting ieder jaar twee miljoen bezoekers en draagt hierdoor significant bij aan de lokale economie van de aangrenzende gemeenten (Goeree-Overflakkee en SchouwenDuivenland). Ongeveer 75 procent van de bezoekers is 'oeverrecreant', 20 procent watersporter en 5 procent sportvisser, sportduiker of maakt gebruik van rondvaarten. Ruim de helft van de recreanten maakt gebruik van één van de recreatieterreinen. Er zijn zes officiële zwemlocaties en 10 officiële duiklocaties. Verder wordt er gedoken op locaties waar de dijk aan diep water grenst en in de buurt geparkeerd kan worden (Ministerie van Infrastructuur en Milieu, 2016).

De Grevelingen is van belang voor de recreatievaart. Van de 11.000 ha is 7.000 ha dieper dan 1.5 meter en bevaarbaar voor de meeste boten. Er bevinden zich 10 jachthavens in het gebied, met 4.400 vaste ligplaatsen. Er zijn ook 15 openbare aanlegplaatsen. Omdat recreatievaart sneller dan 15 kilometer per uur (motorboten, Jetski's en waterskiërs) verstoring kan veroorzaken bij vogels (met name steltlopers in broedgebieden en op hoogwatervluchtplaatsen en watervogels op open water) geldt in de Grevelingen op basis van Rijksregelgeving een maximum toelaatbare vaarsnelheid van 15 kilometer per uur buiten de bestaande aangewezen snelvaargebieden (tussen de Haven Springersdiep en Marina Port Zélande en nabij de Grevelingendam) (Ministerie van Infrastructuur en Milieu, 2016).

Kitesurfen in de Grevelingen is alleen toegestaan aan de noordzijde van de Grevelingendam. Voor deze locatie geldt overlap in ruimte en tijd tussen het gebruik en instandhoudingsdoelstellingen. Om negatieve effecten van kitesurfen op de Natura 2000-instandhoudingsdoelstellingen te voorkomen mag er alleen in de periode 16 maart tot en met 31 oktober gekitesurft worden (Ministerie van Infrastructuur en Milieu, 2016).

Vliegtuigen (zweefvliegtuigen, helikopters en luchtballonen) hebben een groot, voor korte duur, verstorend effect op vogels door hun zichtbaarheid op grote afstand, grote snelheid en relatief veel lawaai. Deze verstoring treedt voornamelijk op bij een vlieghoogte lager dan 1000 voet (300 meter). Voor het vliegen over het Natura 2000-gebied Grevelingen geldt dan ook een minimale vlieghoogte van 1000 voet. Voor het uitvoeren van inspectie en monitoringsvluchten geldt ook deze minimale vlieghoogte. Hiervan kan buiten het broedseizoen (15 maart-15 juli) en de gevoelige winterperiode (november-maart) worden afgeweken als laagvliegen noodzakelijk is voor het doel van de inspectie of monitoring (Ministerie van Infrastructuur en Milieu, 2016).

De Grevelingen is van belang voor de beroepsvisserij. Er bevinden zich 16 oesterkwekerijen in de Grevelingen op 550 hectare, goed voor 2 miljoen platte en Japanse oesters. Verder mogen wilde oesters gevist worden op de 'vrije gronden'. Beroepsvissers vissen op paling en kreeften. Het kreeften seizoen is geopend van 1 april tot 15 juli. Er wordt gevist met hokfuiken, schietfuiken, kubben en korven. Er mag vanwege de rust voor broedende, ruiende en/of overwinterende vogels niet jaarrond gevist worden (Ministerie van Infrastructuur en Milieu, 2016).

Voor de beroepsvaart heeft de Grevelingen nauwelijks betekenis. Er vinden minder dan duizend passages per jaar plaats en er liggen geen grote havens langs de Grevelingen (Ministerie van Infrastructuur en Milieu, 2016). 


\subsection{Natuurwaarden}

Na de afsluiting zijn de natuurwaarden van de Grevelingen sterk veranderd, zowel in het open water als op de drooggevallen slikken en oude schorren. Het meer vormt daarmee een relatief jong ecosysteem dat nog steeds in verandering is na de afsluiting. In deze paragraaf worden de belangrijkste natuurwaarden beschreven die het relevantst zijn in relatie tot mogelijke veranderingen in toekomstig waterbeheer. Eerst wordt een algemene ecologische schets gegeven (op basis van het Natura 2000 Beheerplan 2016 - 2022), waarna meer in detail ingegaan wordt op de natuurwaarden van de eilanden en oevers (terrestrische natuurwaarden) en de natuurwaarden van het open water.

\section{Belangrijke ecologische waarden in de Grevelingen}

Volgens het Natura 2000 Beheerplan Grevelingen 2016 -2022 (Ministerie van Infrastructuur \& Milieu 2016) zijn de belangrijkste ecologische waarden van het Natura 2000 gebied Grevelingenmeer:

- Als het grootste zoutwatermeer van Europa vormt het Grevelingenmeer een belangrijk leefgebied voor kustbroedvogels, moerasbroedvogels van rietruigtes, (doortrekkende en overwinterende) watervogels en roofvogels. Met name kustbroedvogels (kluut, bontbekplevier, strandplevier, visdief, grote stern en dwergstern) zijn belangrijk en het Grevelingenmeer vormt een onmisbare schakel in het trekvogelnetwerk. Vooral voor visetende watervogels is het Grevelingenmeer van uitzonderlijk belang waaronder fuut, middelste zaagbek, geoorde fuut, kuifduiker, dodaars, lepelaar en kleine zilverreiger.

- Diversiteit aan vegetatietypen: zoutminnende pioniervegetaties, zilte graslanden, riet- en zoutvegetatie vochtige duinvalleien, ontzilte graslandvegetaties, duinvegetaties, struwelen en ruigtes. Verschillende zeldzame en beschermde plantensoorten komen in deze vegetaties voor, waaronder de groenknolorchis.

- Het Grevelingenmeer is een belangrijk leefgebied voor de noordse woelmuis.

Het Beheerplan Grevelingen 2016 -2022 (Ministerie van Infrastructuur \& Milieu 2016) duidt ook een aantal knelpunten aan voor het Grevelingenmeer. Samenvattend zijn dit:

- Toekomstige kwaliteit en omvang van de habitattypen met een zilt pionierskarakter (oprukkende successie);

- Aanwezigheid van voldoende geschikt broedgebied voor kustbroedvogels, bruine kiekendieven;

- Afname van optimaal leefgebied voor de noordse woelmuis;

- Afnemende aantallen van enkele niet-broedvogels.

Naast de knelpunten genoemd in het Beheerplan Grevelingen 2016 -2022 (Ministerie van Infrastructuur \& Milieu 2016), wordt in de RSV het probleem van de waterkwaliteit (zuurstofloosheid) als structureel knelpunt voor het Grevelingenmeer vermeld.

\section{Eilanden en oevers}

$\mathrm{Na}$ afsluiting en instelling van de $20 \mathrm{~cm}$ peilverlaging vielen de voormalige slikken en platen permanent droog en begon de geleidelijke ontzilting van deze zandige, drooggevallen delen en ontwikkelde een zoetwaterlens in de bodem.

\section{Vegetatie}

De vegetaties reflecteren voornamelijk een zonering in zoutgehalte, die sterk samen hangt met de hoogteligging, alsmede verschillen in successie, die bepaald worden door het gevoerde beheer. Van laag naar hoog gaat het om volgende types: zilte pioniers, zilt grasland, overstromingsgrasland en duinvalleivegetatie (deels vervangen door ruigte, struweel en bos), en ruigte met wat struweel (in de hoogste zone, op het voormalige schor). De hoogteligging van de verschillende zones verschilt enigszins per plaat. Dit heeft te maken met onder meer verschillen in hoogteprofiel en lutumgehalte van de bodem, hetgeen invloed heeft op de ontkalking (Van de Haterd et al. 2010). Ook de fluctuatie van het peil is niet overal in het meer even groot. Op de kleiige, voormalige schorren ontwikkelden zich ruigtes met harig wilgenroosje, akkerdistel en duinriet en struwelen met gewone vlier en verschillende wilgensoorten. Op de meer zandige delen ontwikkelden zich duinvalleivegetaties op de vochtige delen en duindoornstruwelen en bos waar geen beheer werd gevoerd, alsmede duingraslanden op een enkel, hooggelegen, droog gedeelte (Nienhuis 1985). De vegetatietypen op de oevers weerspiegelen in de huidige situatie een gradiënt van zilte vegetaties naar zoete vegetaties en hoger op de voormalige platen 
vooral de mate van bodemontwikkeling en beheer (successie). Op de oude schorren weten struiken en bomen zich slechts moeizaam te vestigen in de snel ontstane, dichte ruigte. Deze zonering is bijvoorbeeld goed zichtbaar op de Slikken van Flakkee.

Waardevolle vegetatietypen zijn voornamelijk de vochtige, kalkrijke duinvalleien en de brakke overgangsvegetatie van vochtige duinvallei naar zilte vegetaties. Op de platen in de Grevelingen komen relatief grote arealen kalkrijke duinvalleivegetaties voor, die van (inter)nationaal belang zijn. Niet alleen herbergt het Grevelingenmeer één van de grootste oppervlaktes van dit type (habitattype 2190) in ons land, in internationaal opzicht gaat het ook om een bedreigd habitattype (Vulnerable op de Europese Rode Lijst; Janssen et al. 2016), waarbij in Nederland, na Frankrijk en Denemarken, de grootste oppervlakte voorkomt. Vooral in de jonge, kalkrijke vormen komt de Europees beschermde groenknolorchis voor, naast andere orchideeën zoals moeraswespenorchis en vleeskleurige orchis. De populatiegrootte van de groenknolorchis op de oevers en eilanden van het Grevelingenmeer bedroeg zo'n 50.000 exemplaren in 2016 (de Kraker 2017). Circa 90\% van de groenknolorchissen (45.000 ex.) komen in dat jaar voor op de laaggelegen delen van de Veermansplaat en vertegenwoordigen momenteel de grootste populatie van Europa (Figuur 10) ${ }^{4}$. Kleinere populaties staan op de Stampersplaat (2255 ex.), Hompelvoet (705 ex.), Dwars in de Weg (123 ex.) en op de Slikken van Flakkee (1645 ex.). Aantallen variëren ieder jaar en zijn fors toegenomen sinds 2013 (de Kraker 2017). De natte duinvalleivegetaties hebben permanent hoge grondwaterstanden, meestal als gevolg van kwelwater. Relatief droge vormen hebben grondwaterstanden die in de zomer meer dan $50 \mathrm{~cm}$ wegzakken. Ze hebben meer kenmerken van vochtige schraallanden dan van duinvalleivegetatie. Ook in deze vegetaties komen bijzondere soorten voor, zoals slanke gentiaan, herfstschroeforchis, harlekijn, gelobde maanvaren en gewone vleugeltjesbloem. De best ontwikkelde vormen van dit type komen voor op Hompelvoet, waarbij de aantallen harlekijn en herfstschroeforchis een toename laten zien in de periode 2008-2016 (de Kraker 2017).

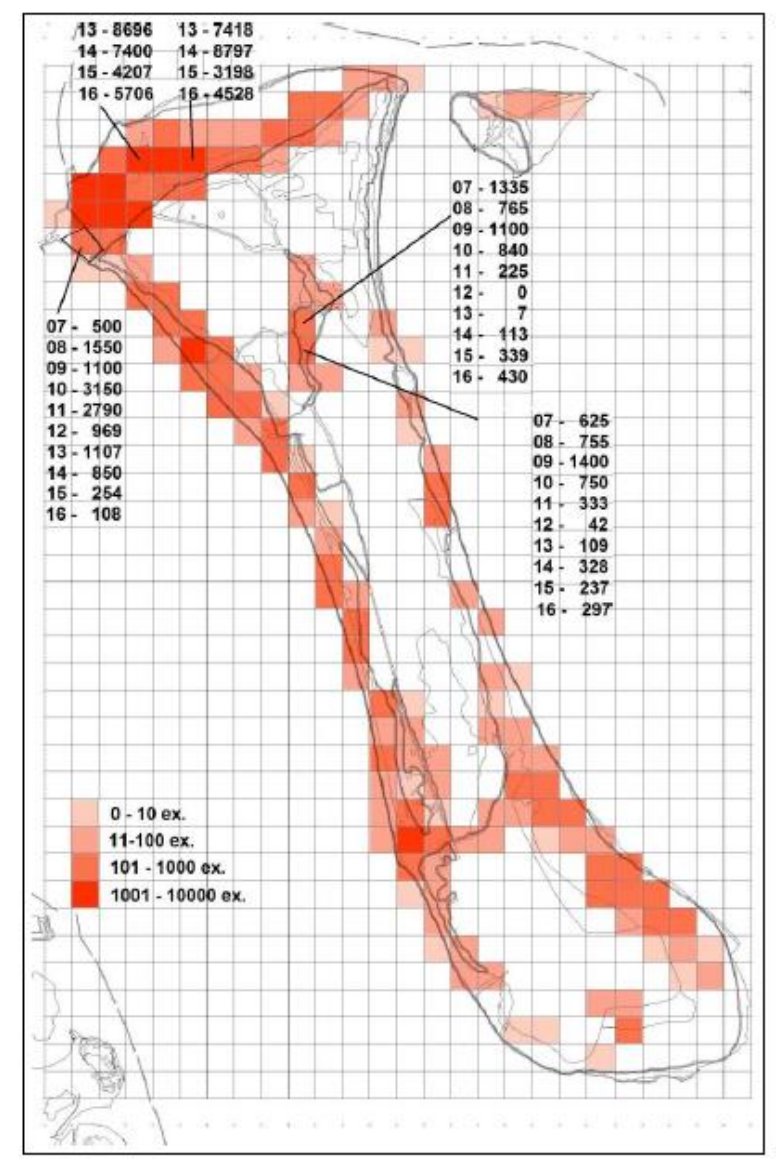

Figuur 10. Voorkomen van de Groenknolorchis binnen vaste proefvlakken en de verspreiding op basis van de telling in 2015 op de Veermansplaat (Bron: de Kraker 2017).

\footnotetext{
${ }^{4}$ In 2003 werd de totale Nederlandse populatie nog op 20.000 geschat (Bolier \&Odé 2003). De grootste nationale populaties die in 2012 zijn gerapporteerd aan de Europese Commissie betreffen die van Frankrijk (ca. 67.000), Nederland en Portugal (60.000) en Denemarken (50.000) (www.eionet.europa.eu).
} 
Het Grevelingenmeer kent momenteel op beperkte schaal zoutminnende vegetaties langs de randen van de voormalige platen. Lage, zandige randen en oude kreken zijn nog steeds begroeid met halofyten als kortarige zeekraal en klein schorrenkruid, die een pionierbegroeiing vormen. Iets hoger in de zonering komen zilte graslanden voor met soorten als gewoon kweldergras, zilte rus en kwelderzegge. De grootste oppervlaktes zilte vegetaties liggen op de Slikken van Flakkee, de Veermansplaat, de Slikken van Bommenede en Hompelvoet. In totaal komt er ongeveer 370 ha zilte vegetaties voor (inclusief de vrij ijl begroeide pioniervegetaties). De omvang van de zoutvegetaties op de Veermansplaat lijken tussen 1987 en 2001 weinig veranderd (Van de Haterd et al. 2010). Maar op sommige oevers lijken ze geleidelijk af te nemen door voortschrijdende verzoeting. Zo is op de Hompelvoet de zoutgrens (tot waar de zoutplanten als zeekraal en gewoon kweldergras voorkomen) in 20 jaar zo'n 40 meter naar de oever opgeschoven (de Kraker 2017).

Naast de hierboven beschreven overgangsvegetaties komen ook andere waardevolle vegetatietypen voor. Dit betreft een kleine oppervlakte droog duingrasland (Hompelvoet; habitattype 2130) en brakke ruigten (Slikken van Flakkee; habitattype 6430), en de spontane bossen van wilgen en berken. Die laatste zijn jonge, natuurlijke bossen die een nieuw ontstaan vegetatietype (Boswilg-associatie) in ons land vormen. Verder vallen de duindoornstruwelen onder de vanuit de Habitatrichtlijn beschermde Europese typen (habitattype 2160), maar toch worden deze als relatief minder waardevol beschouwd, aangezien ze in Nederland (en elders) in een goede toestand verkeren (niet bedreigd zijn), en in de Grevelingen niet bijzonder soortenrijk ontwikkeld zijn.

De waardevolle duinvalleivegetaties worden in stand gehouden door begrazings- en maaibeheer. Voor een uitgebreide beschrijving van het beheer ten behoeve van vegetatie en broedvogels zie de Kraker (2017).

\section{Kustbroedvogels}

Het Grevelingenmeer is één van de belangrijkste broedgebieden voor kustbroedvogels in het Deltagebied (Arts et al. 2016). Door de invloed van het zoute water wordt de vegetatiesuccessie op de laaggelegen delen van de buitendijkse gronden en eilanden geremd en zijn hier nog zoutminnende vegetaties aanwezig. Verder wordt een aantal eilanden jaarlijks door Staatsbosbeheer gemaaid. Deze weinig tot laag begroeide gebieden vormen een aantrekkelijk broedhabitat voor diverse soorten kustbroedvogels zoals kluten, plevieren, meeuwen en sterns. In Tabel 7 staat een overzicht weergegeven van de aantallen kustbroedvogels in het Grevelingenmeer in de afgelopen jaren.

Om het gebied aantrekkelijker voor kustbroedvogels te maken zijn in de loop der jaren door Staatsbosbeheer vele maatregelen uitgevoerd. Op diverse plaatsen werden eilanden gecreëerd zoals op de Slikken van Bommenede, bij de Slikken van Flakkee noord, op het slik bij Dijkwater, aan de westkant van de Veermansplaat en de Hompelvoet. Verder werden in diverse gebieden schelpen aangebracht, zoals op de Slikken van Flakkee zuid, de Slikken van Bommenede en de Kleine Stampersplaat. Veel van deze maatregelen waren zeer succesvol en leidden vaak al in het jaar na uitvoering tot de vestiging van diverse soorten kustbroedvogels (Arts et al. 2016). Door een relatief groot aanbod aan geschikte broedgebieden kunnen de kustbroedvogels in het Grevelingenmeer jaarlijks een keuze maken welke broedplaatsen optimaal zijn. Sternen zijn bijvoorbeeld opportunistisch in hun keuze voor gebied om te broeden. De grote stern heeft in het verleden gepoogd te broeden op de Hompelvoet, Markenje en de Kleine Stampersplaat (de Kraker 2017). Al voor de afsluiting broedde deze soort op de Hompelvoet. In 2003 verhuisde de soort naar de Kleine Stampersplaat. Tussen 2005 en 2009 zijn geen broedparen waargenomen, maar vanaf 2010 broedt de grote stern weer op Markenje met van jaar tot jaar zeer wisselende aantallen. De wisselende keuzes van de sterns worden beter begrepen door het op dezelfde schaal te bekijken als de vogels dat doen. Zo worden er broedlocaties aangetroffen van Noord-Frankrijk tot de Wadden (de Kraker 2017).

Naast het beheer van de broedplaatsen is ook het peilbeheer van het Grevelingenmeer van groot belang voor het ontstaan van geschikt broedhabitat (schaars begroeide delen). Zo wordt het peil in het meer vanaf begin april geleidelijk verlaagd, waardoor er foerageer- en broedgebieden voor kustbroedvogels beschikbaar komen. Ook wordt met een lager waterpeil in de broedtijd de kans op overstroming van de broedplaatsen tijdens een storm aanmerkelijk kleiner. De Kleine Stampersplaat valt door de lage ligging 
voor een groot deel binnen de marges van het peilbeheer waardoor in de zomer (peil van $-0,26 \mathrm{~m}$ NAP) kale delen droogvallen. Dit maakt het gebied potentieel waardevol als broedvogel gebied maar tegelijkertijd ook onderhevig aan erosie. Hier broeden vooral meeuwen, visdief, dwergstern, noordse stern, kluut en strandplevier (de Kraker 2017). In de loop van de zomer wordt het peil weer teruggebracht naar een hoger niveau.

De predatiedruk op broedende vogels en vooral hun eieren en jongen is sinds de eeuwwisseling toegenomen door toename van roofvogels en het voorkomen van de bruine rat wat een negatieve invloed heeft op de broedsuccessen (de Kraker 2017). Naast predatie zijn broedsuccessen afhankelijk van weersomstandigheden die de voedselsituatie beïnvloed, begroeiing en verstoring.

Tabel 7. Overzicht totaal aantallen kustbroedvogels in de Grevelingen in de periode 2002-2016. Rode Lijstsoorten ( $R L$ ) zijn vetgedrukt en de status daarvan aangegeven in kolom 2 ( $G=$ gevoelig, $K=k w e t s b a a r$, $B=$ bedreigd). Bron: de Kraker (2017).

\begin{tabular}{|c|c|c|c|c|c|c|c|c|c|c|c|c|c|c|c|c|}
\hline soort / jaar & $\begin{array}{l}\mathbf{R} \\
\mathbf{L}\end{array}$ & 2002 & 2003 & 2004 & 2005 & 2006 & 2007 & 2008 & 2009 & 2010 & 2011 & 2012 & 2013 & 2014 & 2015 & 2016 \\
\hline 1. $\quad$ Kluut & & 291 & 193 & 223 & 254 & 247 & 321 & 337 & 324 & 300 & 323 & 250 & 202 & 177 & 173 & 125 \\
\hline 2. Bontbekplevier & $\mathrm{K}$ & 18 & 20 & 23 & 27 & 23 & 28 & 31 & 28 & 27 & 22 & 23 & 17 & 10 & 11 & 7 \\
\hline 3. Strandplevier & $\mathbf{B}$ & 64 & 64 & 62 & 81 & 86 & 91 & 58 & 63 & 72 & 66 & 72 & 46 & 46 & 36 & 48 \\
\hline Kokmeeuw & & 419 & 491 & 287 & 105 & 162 & 328 & 497 & 571 & 734 & 724 & 746 & 827 & 890 & 1216 & 884 \\
\hline Zwartkopmeeuw & & 0 & 5 & 9 & 0 & 1 & 5 & 5 & 9 & 55 & 44 & 12 & 76 & 85 & 270 & 410 \\
\hline Stormmeeuw & & 261 & 319 & 325 & 280 & 259 & 305 & 302 & 227 & 279 & 280 & 251 & 256 & 225 & 233 & 266 \\
\hline Kleine Mantelmeeuw & & 371 & 747 & 803 & 538 & 772 & 946 & 789 & 765 & 945 & 989 & 910 & 1062 & 788 & 835 & 790 \\
\hline Zilvermeeuw & & 1261 & 2264 & 2152 & 2496 & 2206 & 2374 & 2369 & 2093 & 2586 & 2006 & 2384 & 3116 & 2592 & 2460 & 2705 \\
\hline 9. Grote Mantelmeeuw & G & 3 & 2 & 4 & 4 & 5 & 8 & 9 & 12 & 10 & 14 & 13 & 18 & 25 & 22 & 22 \\
\hline 10. Grote Stern & $\mathbf{B}$ & 1600 & 4201 & 3300 & 0 & 1 & 0 & 0 & 0 & 465 & 4479 & 1750 & 3800 & 330 & 2000 & 350 \\
\hline 11. Visdief & G & 264 & 424 & 366 & 405 & 659 & 1064 & 814 & 872 & 651 & 624 & 668 & 702 & 771 & 527 & 525 \\
\hline 12. Noordse Stern & & 15 & 43 & 34 & 22 & 56 & 45 & 45 & 59 & 55 & 37 & 51 & 52 & 60 & 65 & 49 \\
\hline 13. Dwergstern & $\mathrm{K}$ & 37 & 36 & 76 & 84 & 134 & 228 & 205 & 152 & 191 & 172 & 170 & 119 & 142 & 112 & 122 \\
\hline
\end{tabular}

\section{Zoogdieren}

Op de eilanden en oevers van het Grevelingenmeer komen verschillende zoogdieren voor zoals de gewone bosspitsmuis, dwergmuis en bruine rat die voornamelijk op de Hompelvoet en Markenje zijn waargenomen (de Kraker 2017). Een bijzondere soort in het gebied is de noordse woelmuis. Vóór de afsluiting kwam dit zoogdier in de Grevelingen niet voor, maar na de afsluiting wist de soort te profiteren van het nieuw ingestelde waterpeil, waarbij grote delen van de vroegere slikken en platen permanent droogvielen. De soort is typerend voor vochtige tot uitgesproken natte vegetaties in laaggelegen gebieden met een hoge dynamiek in de vorm van wisselende waterstanden met 's winters regelmatig water in het maaiveld (Wetsteijn 2011). In drogere gebieden met weinig dynamiek en/of intensieve begrazing wordt de noordse woelmuis weggeconcurreerd door de veldmuis en aardmuis. Het noordelijke Deltagebied vormt één van de voornaamste bolwerken van de noordse woelmuis in Nederland. Doordat de Noordse woelmuis goed kan zwemmen, wist ze al snel de drooggevallen eilanden in de Grevelingen te koloniseren en kon ze zich sterk vermeerderen. Net als in andere gebieden in de Delta kreeg het dier vervolgens concurrentie van andere muizensoorten, waardoor het werd teruggedrongen tot (geïsoleerde) eilanden. Ook blijkt de soort slecht bestand tegen begrazing en eist verlies aan leefgebied door opslag van struweel zijn tol. De eilanden in het Grevelingenmeer (Hompelvoet, Veermansplaat, Kleine Veermansplaat, Grote en Kleine Stampersplaat) vormen één van de belangrijkste leefgebieden voor de noordse woelmuis in Zuidwest-Nederland.

\section{Open water}

$\mathrm{Na}$ de afsluiting zijn er grote veranderingen opgetreden in het watersysteem van het Grevelingenmeer. Tot aan de opening van de Brouwerssluis in 1978 is het meer eerst verzoet wat zijn weerslag had op het ecosysteem. In de periode daarna ontwikkelde het tot een zeer helder zoutwater meer, uniek in het Deltagebied. Doordat het Grevelingenmeer niet in verbinding staat met de grote rivieren is het relatief schoon en oligotroof met relatief helder water en weinig algen. Na de afsluiting werd het meer eerst relatief helder maar vanaf 1990 was een sterke afname van het doorzicht te zien.

\section{Bodemdieren}

De bodemdieren van het zachte substraat vormen het middensegment van het ecosysteem en vervullen een centrale rol in het voedselweb. Bodemdieren spelen door hun activiteit (filteren van water door filterfeeders, bioturbatie, bio-irrigatie) een belangrijke rol in allerlei biogeochemische processen en de 
benthisch-pelagische koppeling. Bodemdieren zijn de belangrijkste voedselbron voor kreeftachtigen, vogels en vissen maar ook voor de mens in de vorm van bv. schelpdieren (mosselen, oesters). De bodemdieren van het zachte substraat (de zandige bodem van het Grevelingenmeer) zijn sinds begin jaren ' 90 bemonsterd binnen het MWTL monitoringsprogramma in de zone van 0-10 meter waterdiepte.

Trends van bodemdieren

De wormen vertegenwoordigen de grootste groep aan soorten gevolgd door geleedpotigen (vooral kreeftachtigen) en weekdieren (vooral schelpdieren). Soorten van andere diergroepen zijn er wel, maar onbeduidend in aantal op het grote geheel. In biomassa domineren de weekdieren. De gemiddelde biomassa in de periode $1990-2000$ is relatief hoog te noemen, vergelijkbaar met rijke delen van de Waddenzee en hoger dan wat er in de Ooster- en Westerschelde wordt gevonden (Hoeksema 2002). Van de weekdieren is het muiltje (Crepidula fornicata) de belangrijkste soort, zowel in aantallen als in gewicht. Bij de wormen domineren de kleinere soorten in aantallen, zoals draadwormen (Capitella capitata) en borstelarme ringwormen (Oligochaeta) en is qua biomassa de zager (Alitta virens) dominant. Het overgrote deel van de bodemdieren filtreren hun voedsel uit het water (ongeveer $90 \%$ van de biomassa aan bodemdieren) (Hoeksema 2002), dit komt door de sterke vertegenwoordiging van schelpdieren. Hoewel in de periode 1990-2000 de opbouw van de bodemdiergemeenschap met voornamelijk dominantie van schelpdieren, kreeftachtigen en wormen geen veranderingen zichtbaar zijn, zijn er duidelijke verschuivingen op soort niveau. In de periode 1990-1994 zijn grote fluctuaties in dichtheid en biomassa te zien maar trends zijn niet te onderscheiden (Wattel 1996). Over de periode 1990-2000 zijn trends beter zichtbaar en is een afname van de biomassa van schelpdieren en slakken te zien waaronder de mossel, platte oester en kokkel, en het wadslakje, de gevlochten fuikhoorn en de Alikruik. De Japanse oester is juist in opkomst (Hoeksema 2002). Volgens Schaub et al. (2002) lijkt het Grevelingenmeer minder geschikt geworden voor een groot aantal soorten die voedsel uit het water filteren: een groot aantal soorten van verscheidene taxonomische groepen (fyla) die er een filtrerende wijze van voedselvergaring op na houden gaan in dichtheden achteruit. Dit zou kunnen komen door de afsluiting van het gebied. Hierdoor is er minder waterbeweging en zakt het zwevend materiaal eerder naar de bodem. Voedsel lijkt eerder terecht te komen op en in de bodem waarvan organismen profiteren die van depositie leven (bv. wormen). Er zijn verschuivingen waargenomen in de soortensamenstelling van de wormen en de groep van de geleedpotigen lijkt stabiel gebleven. Wormachtigen -maar niet alle soorten- zijn aanzienlijk in dichtheden toegenomen. Verder zijn er een aantal wormen soorten sterk in dichtheden afgenomen (Schaub et al. 2002). Deze toename in dichtheden van enkele wormensoorten lijkt zich door te zetten tot 2008 (Wetsteijn 2011). Op basis van monitoringsgegevens uit 2013 is het relatieve aandeel van dichtheden wormensoorten in de zone 0-2 meter in de periode 2010-2013 hoog maar dit komt ook door afname van kreeftachtigen en overige soorten (Leewis et al. 2013). Er komt geen duidelijke verklaring voor deze verschuiving naar voren behalve de constatering dat er nog geen evenwichtssituatie is bereikt en er mogelijk een relatie is met waterkwaliteit, veranderde bodemsamenstelling, en verontreinigingen in het water. Door Sistermans et al. (2006) wordt in de periode tussen 1990-2006 een zeer significante afname van de aantallen bodemdieren en biomassa in het Grevelingenmeer geconstateerd. De neerwaartse trend in bodemdiergemeenschappen heeft betrekking op de ondiepe zone tussen 0-2 meter (vanaf 1990) en 2-6 meter (vanaf 1999) waterdiepte (Wetsteijn 2011) en lijken daardoor niet direct gerelateerd aan het optreden van zuurstofloze condities die vanaf 5 meter waterdiepte op kunnen treden. Op basis van een analyse in 2013 lijkt deze dalende trend in biomassa aan bodemdieren van de ondiepe zone zich voort te zetten (Kater \& Van Onselen 2013). Na 2013 is de jaarlijkse macrobenthosmonitoring van het MWTL programma teruggeschroefd naar $1 \times$ per drie jaar.

In 2017 zijn voor het eerst in het Grevelingenmeer bestandsschattingen uitgevoerd van de natuurlijke schelpdierbestanden in het kader van de monitoring wettelijke onderzoekstaken. De eerste uitkomsten laten zien dat de dichtheden van schelpdieren (met name kokkels (Cerastoderma edule), brakwaterkokkels (Cerastoderma glaucum), Filipijnse tapijtschelp (Ruditapes philippinarum), tapijtschelp (Venerupis corrugata), mesheften (Ensis sp.), en strandgapers (Mya arenaria) zeer laag zijn in de ondiepe zone tot 3 meter in vergelijking met het Veerse Meer. De oorzaak hiervan is nog niet onderzocht en daarmee onbekend (pers. comm. Karin Troost, Wageningen Marine Research). Het bestand aan wilde Japanse oesters (Crassostrea gigas) in het Grevelingenmeer is momenteel nog onbekend, maar wordt in de zomer/najaar van 2018 bemonsterd (pers. comm. Karin Troost, Wageningen Marine Research). 
De relatie bodemdieren en Beggiatoa

De relatie tussen het voorkomen van Beggiatoa bacteriematten en schade aan het bodemleven is significant (Didderen et al. 2013) en is o.a. te verklaren door de concurrentie om zuurstof. Deze relatie wordt nader omschreven door experts van Bureau Waardenburg (zie aantekeningen interview in Bijlage H). De Beggiatoa bacterie komt van nature voor in alle mariene sedimenten, meestal op een aantal centimeter diep in het sediment (t.h.v. de zogenaamde redoxlaag). Beggiatoa matvorming verergert en verlengt de zuurstofloosheid (de bacterie consumeert immers zuurstof waardoor de zuurstofloosheid toeneemt). De mat zelf vormt niet een fysieke barrière die een 'dode bodem' in de hand werkt. De hoofdreden voor het langzame herstel van de bodem is dat er geen bioturbatie meer plaatsvindt na het afsterven van de infauna, waardoor zuurstof niet goed meer in het sediment kan doordringen. Daarbij komt dat gestorven dieren ook bijdragen aan de zuurstofvraag. Hierdoor blijft de situatie langdurig ongunstig.

Bodemdieren van hard substraat

De verharde dijkglooiingen en oeververdedigingen onder het wateroppervlak van het Grevelingenmeer vormen een habitat voor hard substraat soorten zoals Japanse oesters, begroeid met o.a. zakpijpen, sponzen, wieren en mosdiertjes. Hoewel dit habitat een belangrijke rol speelt in het ecosysteem als leefomgeving, schuilplaats en foerageergebied voor veel verschillende soorten ligt de focus in deze studie op het bodemleven van het zacht substraat en wordt daarom niet verder uitgediept. Meer informatie over monitoring van hardsubstraatfauna door duikers van Stichting Anemoon is te vinden in het rapport Het Duiken Gebruiken 3 (Gmelig Meyling et al., 2013).

Vissen

Toen in 1964 het Grevelingenmeer werd afgesloten van de rivieren bood het geen vrije doorgang meer voor diadrome vissen en ging de soortensamenstelling van vissen meer op die van de Oosterschelde lijken. Gedurende de jaren 1960 tot en met 1980 hebben er op de Grevelingen / het Grevelingenmeer frequent visstandsonderzoeken plaatsgevonden, daarna nog slechts driemaal in 1982, 1988 en 1994 waarvan het onderzoek in 1994 het meest compleet is uitgevoerd met focus op zowel pelagische als bodemvissen (Hop 2016). Daarna is lange tijd geen onderzoek naar visstand meer verricht en zijn nog enkele beperkte bemonsteringen uitgevoerd met wisselende focus en bemonsteringstechnieken totdat in 2016 (najaar) en 2017 (voorjaar en najaar) visstandsonderzoek is gedaan door ATKB (Hop 2016; Hop 2017a; Hop 2017b) die een inzichtelijke beschrijving geeft van de visstand die hier kort wordt samengevat.

In 2017 zijn totaal 25 vissoorten aangetroffen waarin de estuariene residente soorten goed zijn vertegenwoordigd zoals bot, botervis, grondels, zeenaalden, puitaal en zeedonderpad en marien juveniele soorten haring, koornaarvis, platvissen, steenbolk en wijting, mariene seizoensgasten zoals sprot en diadrome soorten als paling en driedoornige stekelbaars. De huidige soortensamenstelling bestaat volledig uit soorten die in een recent of verder verleden ook in het Grevelingenmeer zijn aangetroffen. Vooral in het voorjaar bevindt het hoogste aantal soorten zich in het westelijke deel van het Grevelingenmeer. Dit gebied staat onder directe invloed van de Brouwerssluis. Over het algemeen is het aantal soorten in de waterkolom lager dan het aantal soorten dat zich tegen de bodem bevindt. In het najaar is de soortenrijkdom meer gelijk verdeeld over het meer, waarbij de grootste aantallen in het gebied rondom de Flakkeese spuisluis zijn aangetroffen. De visstand in het Grevelingenmeer wordt gekenmerkt door redelijke aantallen (pelagische) vis, maar een relatief lage visbiomassa. Het visbestand bestaat voornamelijk uit kleine vis. Dit is vergelijkbaar met de bevindingen in 1994. De visstand wordt gedomineerd door sprot en haring in het pelagische deel van de waterkolom en brakwatergrondel op de bodem van het meer. In het verleden was het dikkopje veelal dominant over de brakwatergrondel; op dit moment is de brakwatergrondel dominant. Overigens kunnen de aantallen grondels (brakwatergrondel, zwarte grondel) sterk fluctueren gedurende het jaar. Mogelijk speelt de periodieke zuurstofloosheid in de diepere delen van het Grevelingenmeer hierin een rol. In het westelijke deel van het Grevelingenmeer is aanzienlijk meer vis aanwezig dan in het oostelijke deel. Richting de Brouwerssluis loopt de geschatte omvang van het visbestand op tot $160 \mathrm{~kg} / \mathrm{ha}$ en $61.000 \mathrm{stuks} / \mathrm{ha}$ in het voorjaar en zelfs $370 \mathrm{~kg} / \mathrm{ha}$ en 58.000 stuks/ha in het najaar. In het oostelijke deel heeft het visbestand veelal een omvang van maximaal enkele kilogrammen per hectare en veelal minder dan 1.000 stuks/ha. In het najaar was de aangetroffen visstand nabij de Flakkeese spuisluis, ten opzichte van de overige delen van het meer, relatief omvangrijk (circa $18 \mathrm{~kg} / \mathrm{ha}$ en $3.000 \mathrm{stuks} / \mathrm{ha}$ ). Dit lijkt 
verband te houden met de inzet van de Flakkeese spuisluis. Paling is een vissoort die over het algemeen onderbelicht blijft bij visstandsonderzoek. Dit geldt in het bijzonder voor bevissingen die overdag uitgevoerd worden. Tijdens het onderzoek in 2017 is slechts één paling gevangen. In 1994 werden er met de pelagische kuil nog ruim 100 palingen gevangen. Deze resultaten suggereren een afname in het palingbestand.

\section{Watervogels}

Ook de vogelpopulaties hebben grote veranderingen ondergaan na de afsluiting en de daarop volgende verschuivingen in visfauna, bodemfauna en vegetatie. Het Grevelingenmeer is een belangrijk gebied voor overwinterende watervogels. Er wordt onderscheid gemaakt in verschillende groepen vogels: viseters, zoo-benthos eters en planteneters. Die worden hieronder apart besproken.

\section{Viseters}

Het Grevelingenmeer is van uitzonderlijk belang voor visetende watervogels door het aanbod van potentiële prooivissen maar ook door het relatief heldere water (Wattel 1996). Het Grevelingenmeer herbergt in de winter en trektijd grote aantallen watervogels zoals fuut, geoorde fuut en middelste zaagbek. Voor de geoorde fuut is de Grevelingen momenteel, met duizenden vogels in de maanden augustus en september, verreweg het belangrijkste nazomergebied van Nederland. In de jaren ' 90 trad sterke toename op van een aantal soorten viseters zoals aalscholver, geoorde fuut en enorme groei van het aantal futen in het westelijk deel waarvan er in het jaar 199416.500 individuen zijn geteld in het Grevelingenmeer (Wattel 1996). Verklaringen hiervoor zijn mogelijk de toename in prooivissen, zachte winters, verbeterde intrekmogelijkheden voor vissen als haring en sport door het langer openstaan van de Brouwerssluis in het voorjaar. Eind jaren 90 werd een afname gesignaleerd van de fuut en de middelste Zaagbek terwijl er elders in het Deltagebied geen sprake was van dalende aantallen. De kleine zilverreiger, een soort van ondiep water, is daarentegen in opkomst en neemt in aantallen toe (Hoeksema 2002). In de periode tot 2004 lijkt het aantal visetende vogels zich te herstellen en blijft stabiel in de jaren daarna (Wetsteijn 2011). Omdat visetende vogels foerageren op vissen kunnen verschuivingen in aantallen waarschijnlijk verklaard worden door veranderingen in de visstand (Bouma et al. 2008). Uit analyse van recente vogelgegevens door RoyalHaskoning DHV (2016) blijkt dat de viseters van open water een negatieve trend laten zien met een sterk negatieve trend voor fuut en kuifduiker en matig negatieve trend voor geoorde fuut. De aantallen van aalscholver lijken stabiel en de aantallen van dodaars lijken licht toe te noemen. Visetende vogels van ondiep water, Kleine zilverreiger en Lepelaar, laten een toename zien vanaf 1997, wat suggereert dat de draagkracht van het gebied voor deze soorten voldoende is. Door het vrijwel ontbreken van voormalige slikken en platen, is het oostelijke deel van de Grevelingen minder geschikt voor deze soorten.

\section{Bodemdiereters}

Doortrekkende en overwinterende vogels die zijn aangewezen op wadplaten, zijn over het algemeen sterk afgenomen na de afsluiting (scholekster, rosse grutto). Andere bodemdiereters daarentegen, zoals Pijlstaart en Bergeend, zijn toegenomen. Opvallend ook is de toename van steltlopers als bonte strandloper, wulp en tureluur. Ondanks het verdwijnen van de intergetijdengebieden in het Grevelingenmeer heeft het gebied nog steeds een waardevolle functie voor bodemdieretende vogels van oevers en ondiep water zoals kanoetstrandloper, scholekster, wulp, bontbekplevier, strandplevier, brilduiker, bergeend en rosse Grutto. De steltlopers komen voornamelijk naar het Grevelingenmeer vanuit de Oosterschelde om het te benutten als hoogwatervluchtplaats, vermoedelijk omdat er beperkte verstoring is (Hoeksema 2002). De trends in aantallen van soorten bodemdieretende vogels tonen een wisselend beeld op basis van een analyse van gegevens t/m 2014 (RoyalHaskoning DHV 2017).

\section{Planteneters}

Planteneters zijn of sterk toegenomen (brandgans, grauwe gans, smient, slobeend) of min of meer gelijk gebleven (rotgans, kolgans, wilde eend). De planteneters vormen de talrijkste groep in het Grevelingenmeer. De talrijkste planteneters in het Grevelingenmeer zijn smient, wilde eend, brandgans, rotgans, meerkoet en grauwe gans. Het zijn doortrekkende en overwinterende vogels, vooral aanwezig tussen september en maart. Het open water en de oevers van de Grevelingen worden als slaap/rustplek en foerageerplek gebruikt. Ze foerageren op waterplanten en wieren, of aangrenzende voedselrijke graslanden. De talrijkste soorten binnen deze groep betreffen (oplopend in aantal): meerkoet, grauwe gans, wilde eend, rotgans, brandgans en smient ( RoyalHaskoning DHV 2017). Sinds het begin van de 
tellingen (1987) neemt deze voedselgroep gestaag toe. De recente trends over de jaren 2010 t/m 2014 zijn veelal stabiel tot positief ( RoyalHaskoning DHV 2017).

\section{Zeezoogdieren}

De zeezoogdieren die voorkomen in het Grevelingenmeer zijn gewone zeehond (Phoco vitulina), grijze zeehond (Halichoerus grypus) en bruinvis (Phocoena phocoena). In het Grevelingenmeer rusten de zeehonden op basaltblokken-dammen die dienen als oeververdediging van de eilanden. Gewone en grijze zeehond laten beide een positieve trend zien in het Deltagebied (Arts et al. 2017). Voor de gewone zeehond is deze trend ook zichtbaar in het Grevelingenemeer De grijze zeehond komt in lage aantallen ( $<5$ individuen) voor. Zeehonden en bruinvissen kunnen slechts via twee mogelijkheden de Grevelingen bereiken: via de Brouwerssluis in het westen of via de Grevelingensluis bij Bruinisse. In 2006 is voor het eerst melding gedaan van een bruinvis in de Grevelingen (Camphuysen \& Heijboer, 2008).

\section{Zeegras}

Vlak na de afsluiting kwam op de ondiepe, onderwater staande platen massaal groot zeegras (Zostera marina) voor, een soort die voor de Deltawerken slechts bekend was van een enkele plek in het Zeeuwse en Zuid-Hollandse estuarium. Met zo'n 4.400 ha aan zeegrasvelden was de Grevelingen in 1978 de grootste groeiplaats van deze mariene plant in Nederland. Sinds de jaren ' 80 ging het areaal in het Grevelingenmeer echter gestaag achteruit en momenteel is de soort helemaal verdwenen (http://www.clo.nl/indicatoren/nl123402-zeegras). Er zijn aanwijzingen dat de soort verdwenen is door het stijgende zoutgehalte wat mogelijk ook te maken heeft met het voorkomen van een estuariene populatie van groot zeegras die minder goed hoge zoutgehalte kan tolereren (Kamermans et al. 1999). Recent is men begonnen met een zeegras herintroductie in het Grevelingenmeer.

\subsection{Natuurbeleid en -wetgeving}

Sinds de afsluiting door de Deltawerken is de Grevelingen het grootste zoutwatermeer van Europa en bevat een aantal eilanden en uitgestrekte oeverlanden. Het is een belangrijk leefgebied voor kustbroedvogels, moerasbroedvogels van rietruigtes, (doortrekkende en overwinterende) watervogels en roofvogels. Daarnaast is het van belang voor (buitendijkse) habitattypen en hieraan gebonden soorten, zoals Noordse woelmuis en Groenknolorchis.

Voor de Grevelingen zijn een aantal Natura 2000-kernopgaven geformuleerd:

- behoud foerageerfunctie van visetende vogels (fuut, geoorde fuut en middelste zaagbek).

- het behoud van ongestoorde rustplaatsen en optimaal voortplantingshabitat voor bontbekplevier, strandplevier, kluut, grote stern, dwergstern, visdief en grijze zeehond.

- $\quad$ het behoud van geïsoleerde eilanden als leefgebied voor noordse woelmuis.

- $\quad$ het behoud van de platen met lage begroeiingen van vochtige (kalkrijke) duinvalleien, grijze duinen, kruipwilgstruwelen en groenknolorchis.

Om de hierboven genoemde kernopgaven te realiseren zijn instandhoudingsdoelen geformuleerd. Instandhoudingsdoelstellingen voor de kwalificerende habitattypen, habitatsoorten en Vogelrichtlijnsoorten zijn opgenomen in bijlage I. Van de soorten waarvoor instandhoudingsdoelen zijn gesteld behoren twee Habitatrichtlijnsoorten (noordse woelmuis en groenknolorchis) en veertien Vogelrichtlijnsoorten (bontbekplevier, strandplevier, grote stern, visdief, dwergstern, kleine zilverreiger, wintertaling, pijlstaart, slobeend, brilduiker, middelste zaagbek, slechtvalk, goudplevier en tureluur) tot Rodelijst soorten.

De fysische, chemische en ecologische kwaliteit van de Grevelingen wordt getoetst aan de hand van de Kaderrichtlijn Water. In Bijlage $\mathrm{J}$ is het voorgestelde Goed Ecologisch Potentieel (GEP) samengevat. De terugkeer van zeegras in het Grevelingenmeer is als extra doel opgenomen in het kader van de Kaderrichtlijn Water (KRW).

De focus van deze studie is niet de toetsing van natuurbeleid en -wetgeving, dit is uitgebreid gedaan in de Natuureffecten studies (NES). Wel gaan we in op de mate van verlies van Natura 2000-habitattypen H1310A (Zilte pionierbegroeiingen - zeekraal en H2190B (Vochtige duinvalleien - kalkrijk) door overspoeling bij de verschillende scenario's (alinea 5.3). 


\section{Ecotopenkaarten en uitkomsten modellering}

In dit hoofdstuk worden eerst de resultaten besproken met betrekking tot het OD-model. Het OD-model levert de waterbalans voor het 3D-model. De (ruimtelijke verdeling van) waterstanden inclusief windopzet wordt berekend met het 3D-waterbewegingsmodel met deze waterbalans als modelinvoer. Vervolgens wordt ingegaan op de waterkwaliteit (zuurstof, nutriënten en primaire productie, welke met de 3D-modellering zijn bepaald.

\subsection{Resultaten van het OD-model: Waterbalans}

Met het OD-model zijn de volgende scenario's doorgerekend: RSV (scenario 1), RSV-Springtij (scenario 2), en Getij30 (scenario 3). Het scenario '0. Huidige situatie' is niet met het OD-model doorgerekend, omdat deze waterstandsvariatie op basis van metingen beschikbaar is. Het scenario '4. RSV-peilbeheer' is niet doorgerekend met het model, omdat deze fijnafregeling van de waterstand met de kunstwerken op vele manieren gedaan kan worden en niet nauwkeurig opgezet kan worden in het model. Tenslotte is ook scenario ' 5 . Zeespiegelstijging' niet met het 0D-model doorgerekend. Voor de waterstandsvariatie wordt aangenomen dat deze gelijk is aan scenario ' 1 . RSV' met een verschuiving omhoog van $40 \mathrm{~cm}$.

De opzet van het OD-model is beschreven in Bijlage E. De waterbalans bestaat uit debieten per 10 minuten door de Brouwerssluis, de Flakkeese spuisluis en de nieuwe doorlaat in de Brouwersdam. De Brouwerssluis en de Flakkeese spuisluis staan permanent open totdat de in het betreffende scenario toegestane bovengrens en ondergrens van de waterstand wordt overschreden. De nieuwe doorlaat in de Brouwersdam wordt gebruikt om de toegestane waterstandsvariatie inclusief middenpeil in detail af te regelen, bijvoorbeeld door (een deel van de) kokers te sluiten.

Ter illustratie van de cumulatieve verdeling van de waterstand en de cumulatieve verdeling van de hoogste en laagste waterstand per getij zijn per scenario weergegeven in Figuur 11, Figuur 12 en Figuur 13. Onderscheid wordt gemaakt tussen de verdeling voor het hele jaar en voor de maanden april $t / m$ september. In het OD-model wordt de nieuwe doorlaat het hele jaar gelijk aangestuurd. Omdat de waterstand op de Noordzee in het winterhalfjaar gemiddeld hoger is door gemiddeld hogere windsnelheden dan in het zomerhalfjaar, ligt de cumulatieve verdeling over het hele jaar hoger dan die in de zomermaanden. De afregeling van het $0 D$-model is op basis van de maanden april $\mathrm{t} / \mathrm{m}$ september gedaan. Ter illustratie van de waterstandsvariatie wordt tevens een tijdserie van 1 juni tot 15 juli 2008 getoond. 


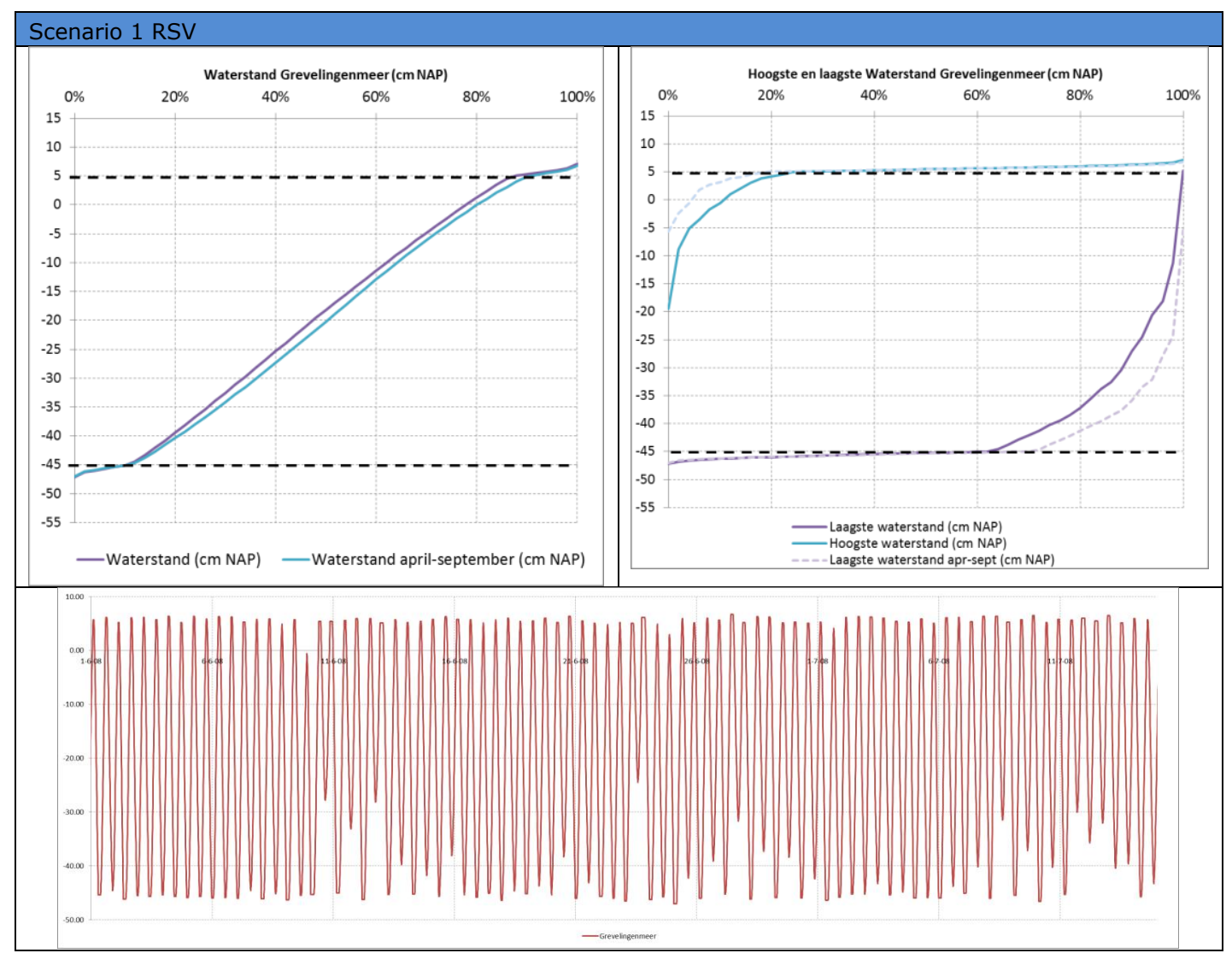

Figuur 11. De cumulatieve verdeling van de waterstand en de cumulatieve verdeling van de hoogste en laagste waterstand per getij van Scenario '1. RSV' (50 cm getijslag, middenpeil $-0,20 \mathrm{~m} \mathrm{NAP).}$

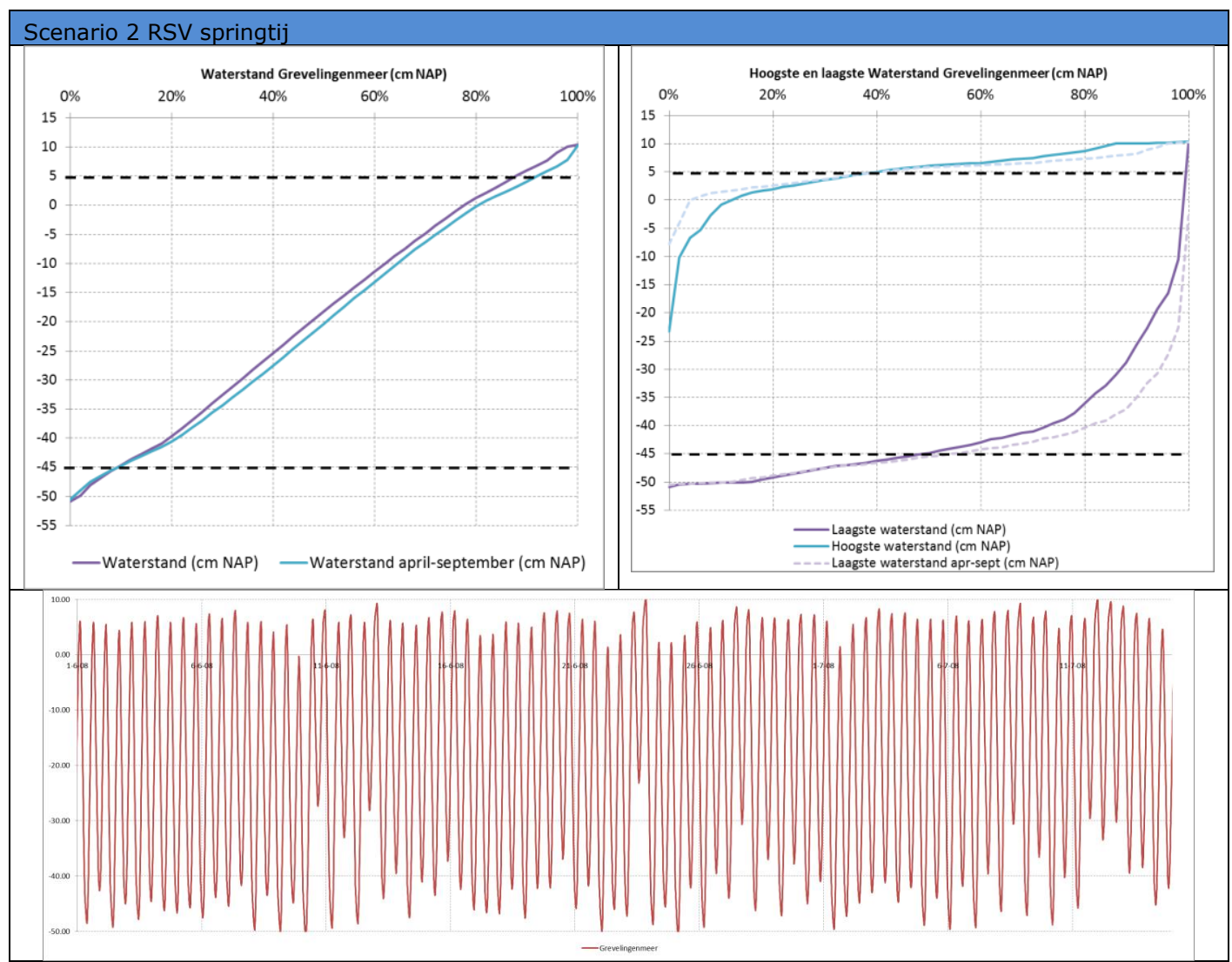

Figuur 12. De cumulatieve verdeling van de waterstand en de cumulatieve verdeling van de hoogste en laagste waterstand per getij van Scenario '2. RSV Springtij' (50 cm getijslag met springtij-doodtij cyclus, middenpeil -0,20m NAP). 


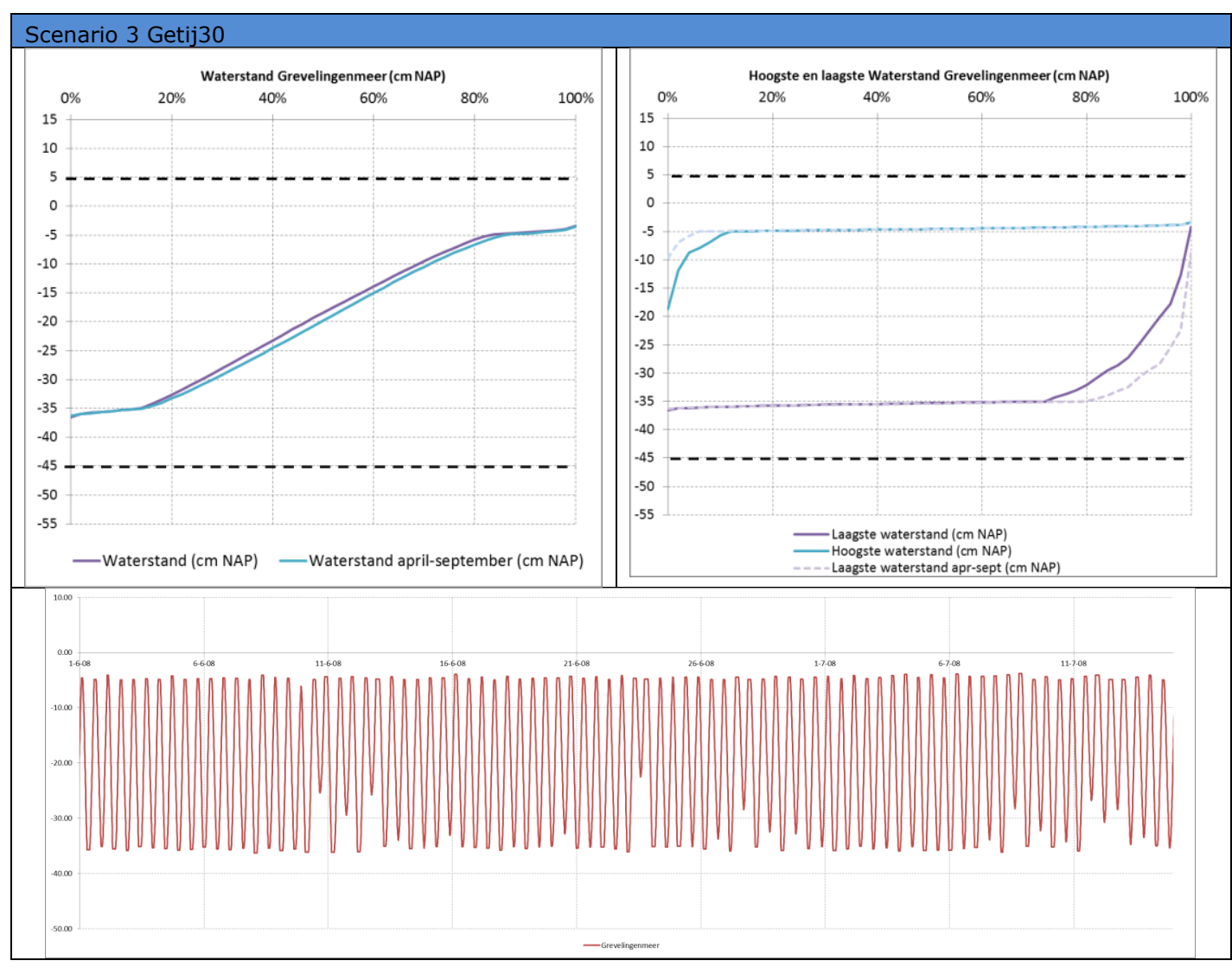

Figuur 13. De cumulatieve verdeling van de waterstand en de cumulatieve verdeling van de hoogste en laagste waterstand per getij van Scenario '1. Getij30' (30 cm getijslag, middenpeil -0,20m NAP).

\subsection{Ecotopen per scenario}

De ecotopenkaarten voor de verschillende scenario' s zijn weergegeven in Bijlage K. In Bijlage L en Bijlage $M$ zijn de kaarten in meer detail weergegeven voor respectievelijk de deelgebieden Hompelvoet en Veermansplaat. In Figuur 14 en Tabel 8 zijn de totale arealen van de ecotopen voor de verschillende scenario's weergegeven. Benadrukt dient te worden dat de geschatte oppervlaktes benaderend zijn, onder meer omwille van de onzekerheid in de bodemhoogte van de ondiepe zone (zie paragraaf 2.4.1). In het scenario RSV met $50 \mathrm{~cm}$ getijslag ontstaat zo'n 1100 ha intergetijdengebied wat ten koste gaat van ondiep water (zo'n 400 ha afname), en het ecotoop zomer droog (zo'n 300 ha) omwille van het ontbreken van een vast peilbeheer in dit scenario. Het ecotoop terrestrisch met zoutinvloed neemt in omvang wat toe en schuift in de hoogte op ten koste van het terrestrisch zoet ecotoop (zo'n 400 ha afname).

Het scenario RSV Springtij is vergelijkbaar met het scenario RSV, alleen ontstaat hier een klein areaal aan schor ecotoop door de springtij/doodtij cyclus (zo'n 30 ha).

In het scenario Getij 30 ontstaat een geringer areaal intergetijdengebied (zo'n 800 ha) in vergelijking met scenario RSV, en ook in dit scenario gaat dit ten koste van ondiep water (zo'n 250 ha afname), en het ecotoop zomer droog (zo'n 300 ha) omwille van het ontbreken van een vast peilbeheer in dit scenario. Ook in dit scenario neemt het ecotoop terrestrisch met zoutinvloed toe (zo'n 100 ha), en neemt het ecotoop terrestrisch zoet in omvang af (zo'n 275 ha).

In het scenario met peilbeheer leidt het terugbrengen van het getij tot een toename van het intergetijdengebied tot maximaal 1650 ha. Hiervan is slechts een klein deel permanent intergetijdengebied, terwijl grote delen dan wel gedurende de zomer permanent droog vallen (Winter intergetijdengebied) of permanent onder water staan tijdens de winter (Zomer intergetijdengebied). In dit scenario neemt het ecotoop terrestrisch zoet fors af (zo'n 850 ha), terwijl het ecotoop terrestrisch met zoutinvloed wat toeneemt, vergelijkbaar met de andere scenario's. Dit is niet onlogisch gezien de inschatting van het areaal van dit ecotoop gebaseerd is op de zoutinvloed op basis van de huidige verspreiding van zilte vegetaties en in het model mee opschuift naar boven toe (deels ten koste van terrestrisch zoet). 
In het scenario met zeespiegelstijging (RSV-zeespiegelstijging) neemt het areaal sublitoraal (ondiep en diep water ecotoop) toe met zo'n 450 ha ten opzichte van de Huidige situatie. Het areaal permanent intergetijdengebied is kleiner dan in het RSV scenario, en ook het ecotoop terrestrisch zoet neemt fors af.

Het areaal zomer droog komt alleen in de Huidige situatie voor als gevolg van het peilbeheer t.b.v. broedvogels (zo'n 300 ha). In het scenario RSV peilbeheer is een vergelijkbaar ecotoop (Winter intergetijdengebied) dat ook tijdens de zomerperiode droogvalt. Dit areaal is met zo'n 550 ha groter dan in de Huidige situatie.

Het verlies aan terrestrische ecotopen is het grootst in de scenario's RSV-zeespiegelstijging en RSVpeilbeheer (34-39\% verlies).

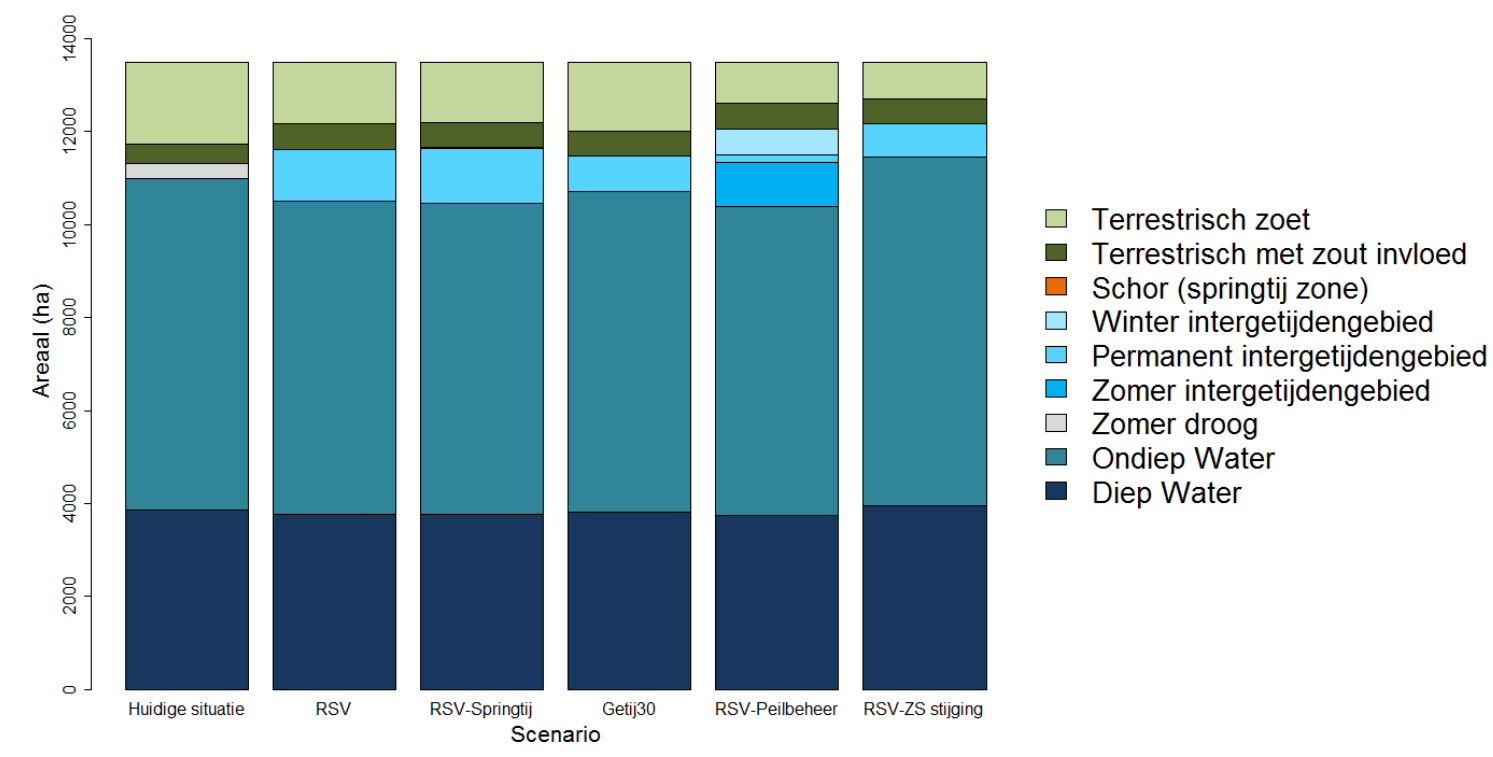

Figuur 14. Arealen (ha) van de verschillende ecotopen voor de verschillende scenario's.

Tabel 8. Arealen (ha) van de verschillende ecotopen voor de verschillende scenario's.

\begin{tabular}{|l|r|r|r|r|r|r|}
\hline & $\begin{array}{c}\text { Huidige } \\
\text { situatie }\end{array}$ & RSV & $\begin{array}{c}\text { RSV- } \\
\text { Springtij }\end{array}$ & Getij30 & $\begin{array}{c}\text { RSV } \\
\text { Peilbeheer }\end{array}$ & $\begin{array}{c}\text { RSV ZS } \\
\text { stijging }\end{array}$ \\
\hline Terrestrisch zoet & 1761 & 1336 & 1299 & 1490 & 895 & 788 \\
\hline Terrestrisch met zoutinvloed & 412 & 540 & 540 & 518 & 540 & 547 \\
\hline totaal terrestrisch & 2173 & 1876 & 1839 & 2008 & 1435 & 1335 \\
\hline Schor (springtij zone) & 0 & 0 & 28 & 0 & 0 & 0 \\
\hline Winter intergetijdengebied & 0 & 0 & 0 & 0 & 559 & 0 \\
\hline Permanent intergetijdengebied & 0 & 1120 & 1161 & 780 & 153 & 704 \\
\hline Zomer intergetijdengebied & 0 & 0 & 0 & 0 & 957 & 0 \\
\hline Totaal Intergetijden & 0 & 1120 & 1189 & 780 & 1669 & 704 \\
\hline Zomer droog & 324 & 0 & 0 & 0 & 6 & 0 \\
\hline Ondiep Water & 7141 & 6734 & 6708 & 6895 & 6651 & 7505 \\
\hline Diep Water & 3858 & 3767 & 3762 & 3814 & 3742 & 3952 \\
\hline Totaal water (incl. zomer droog) & 11323 & 10501 & 10470 & 10709 & 10393 & 11457 \\
\hline Totaal & 13496 & 13497 & 13498 & 13497 & 13497 & 13496 \\
\hline
\end{tabular}




\subsection{Verlies Natura 2000-habitat}

Voor de Natura 2000-habitattypen H1310 (Zilte pionierbegroeiingen) en H2190B (Vochtige duinvalleien - kalkrijk) is ingeschat in welke mate ze overspoelen door het introduceren van een gedempt getij in de verschillende scenario's. Voor habitattype H1310 kan onderscheid gemaakt worden in zilte pionier begroeiingen met zeekraal (H1310A) en met zeevetmuur (H1310B). Habitattype H1310B is niet meegenomen in de analyse, aangezien van de begroeiingen van dit type in de afgelopen 15 jaar meer dan $90 \%$ van de oppervlakte door successie is overgegaan in andere habitattypen en dit habitattype slechts een zeer kleine oppervlakte beslaat.

Daar waar de habitattypes H1310A en H2190B gedurende langere tijd onder water komen te staan met zout water zullen de zilte habitats in oppervlakte en locatie veranderen en de vochtige duinvalleien verdwijnen. $\mathrm{Er}$ is een analyse uitgevoerd naar welke delen van deze habitattypen onder invloed komen te staan van het getij in de verschillende scenario's. Hiervoor is gebruik gemaakt van twee verschillende Natura 2000 habitatkaarten: de habitatkaart gemaakt door Bureau Waardenburg (2013) en de kaart gemaakt door Alterra Wageningen UR (2011). Beide zijn echter nog niet officieel goedgekeurd (zie paragraaf 2.6).

Tabel 9a geeft de resultaten van de analyse met de habitatkaart van Bureau Waardenburg en Tabel 9b met de habitatkaart van Alterra Wageningen UR en de bijbehorende figuren zijn opgenomen in Bijlage $\mathrm{N}$. Hierin is te zien dat het terugbrengen van getij voornamelijk direct effect heeft op het habitattype H1310A zilte pionierbegroeiingen met zeekraal. Volgens de gegevens gebaseerd op de Bureau Waardenburg habitatkaart (Tabel 9a) zal in de RSV scenario's meer dan 92\% van dit habitattype overspoelen en in het Getij30 scenario $82 \%$. Volgens de Alterra Wageningen UR habitatkaart (Tabel9b) is dit meer dan 92\% in de RSV scenario's en 83\% in het Getij30 scenario. Het areaal H1310A kan een bepaalde mate van overspoeling aan en kan ook beneden de hoogwaterlijn voorkomen maar is wel afhankelijk van een geleidelijke overgang van kaal slik/plaat naar hoger gelegen schor. Het overspoelen en potentieel opschuiven van dit habitat wordt bediscussieerd in paragraaf 6.4. Het habitattype H2190B vochtige duinvalleien - kalkrijk zal ook voor een deel overstromen. Volgens de Bureau Waardenburg habitatkaart (Tabel9a) zal in de RSV scenario's 14\% of meer overspoelen en $7 \%$ overspoeling van dit habitat in het Getij30 scenario. Volgens de Alterra Wageningen UR habitatkaart (Tabel9b) zal in de RSV scenario's $11 \%$ of meer overspoelen en $6 \%$ in het Getij30 scenario. Het areaal H2190B dat overstroomt zal waarschijnlijk geheel verloren gaan. In de aanvulling op de Natuureffectenstudie (RoyalHaskoningDHV, 2017) wordt het verlies van H2190B op 5\% geschat voor het RSV scenario. Dit verschil is te verklaren doordat in deze studie andere hoogte- en diepte gegevens zijn gebruikt.

In de tabellen is te zien dat er in de huidige situatie ook areaal van beide habitattypen als 'sublittoraal' wordt aangeduid, vooral het habitattype H1310A. Dit kan een gevolg zijn van de onnauwkeurigheid van de oeverprofielen, maar ook doordat er op de Slikken van Flakkee een laaggelegen kom is ontstaan waar deze habitattypen voorkomen met een walletje aan de waterzijde waardoor het gebied niet of nauwelijks onder water loopt. Het wordt dus aangeduid als sublittoraal vanwege de (hoogte)ligging beneden het waterpeil maar is in werkelijkheid een (meestal) droog liggend gebied met vegetatie.

Tabel9a. Arealen (ha) van de habitats H1310A (Zilte pionierbegroeiingen -zeekraal, totaal 289 ha) en H2190B (Vochtige duinvalleien - kalkrijk, totaal 227 ha) die bij de verschillende varianten vallen binnen de Terrestrische ecotopen en ecotopen die (periodiek) onder water komen te staan ((sub)litorale ecotopen). Natura2000 habitats gebaseerd op habitatkaart van Bureau Waardenburg (2013).

\begin{tabular}{|l|c|c|c|c|}
\hline Scenario & \multicolumn{2}{|c|}{ H1310A } & \multicolumn{2}{c|}{ H2190B } \\
\hline & Terrestrisch & (Sub)litoraal & Terrestrisch & $($ Sub)litoraal \\
\hline Huidige situatie & $202(70 \%)$ & $87(30 \%)$ & $225(99 \%)$ & $2(1 \%)$ \\
\hline RSV & $24(8 \%)$ & $265(92 \%)$ & $195(86 \%)$ & $32(14 \%)$ \\
\hline RSV-springtij & $20(7 \%)$ & $269(93 \%)$ & $190(84 \%)$ & $37(16 \%)$ \\
\hline Getij30 & $53(18 \%)$ & $236(82 \%)$ & $211(93 \%)$ & $16(7 \%)$ \\
\hline RSV-peilbeheer & $3(1 \%)$ & $286(99 \%)$ & $137(60 \%)$ & $90(40 \%)$ \\
\hline RSV-zeespiegelstijging & $3(1 \%)$ & $286(99 \%)$ & $116(52 \%)$ & $109(48 \%)$ \\
\hline
\end{tabular}


Tabel9b. Arealen (ha) van de habitats H1310A (Zilte pionierbegroeiingen -zeekraal, totaal 211 ha) en H2190B (Vochtige duinvalleien - kalkrijk, totaal 351 ha) die bij de verschillende varianten vallen binnen de Terrestrische ecotopen en ecotopen die (periodiek) onder water komen te staan ((sub)litorale ecotopen). Natura2000 habitats gebaseerd op vegetatiekaart van Alterra Wageningen UR (2011).

\begin{tabular}{|l|c|c|c|c|}
\hline Scenario & \multicolumn{2}{|c|}{ H1310A } & \multicolumn{2}{c|}{ H2190B } \\
\hline & Terrestrisch & (Sub)litoraal & Terrestrisch & (Sub)litoraal \\
\hline Huidige situatie & $152(69 \%)$ & $59(28 \%)$ & $344(98 \%)$ & $7(2 \%)$ \\
\hline RSV & $17(8 \%)$ & $194(92 \%)$ & $312(89 \%)$ & $39(11 \%)$ \\
\hline RSV-springtij & $13(6 \%)$ & $198(94 \%)$ & $307(87 \%)$ & $44(13 \%)$ \\
\hline Getij30 & $36(11 \%)$ & $175(83 \%)$ & $331(94 \%)$ & $20(6 \%)$ \\
\hline RSV-peilbeheer & $1(1 \%)$ & $210(100 \%)$ & $225(64 \%)$ & $126(36 \%)$ \\
\hline RSV-zeespiegelstijging & $1(1 \%)$ & $210(100 \%)$ & $192(55 \%)$ & $159(45 \%)$ \\
\hline
\end{tabular}




\subsection{Resultaten van het 3D-model: effecten op zuurstofhuishouding en waterkwaliteit}

Met het 3D-model zijn de volgende scenario's doorgerekend:

0 . Huidige situatie

1. RSV

2. RSV-Springtij

3. Getij30

4. -

5. Zeespiegelstijging

Het scenario '0. Huidige situatie' was al beschikbaar uit Spiteri \& Nolte (2010) en beschrijft de situatie van 2008. Dit betekent dat het effect van de Flakkeese spuisluis die sinds begin 2017 in gebruik is, niet meegenomen is in deze referentie. $\mathrm{Er}$ is voor dit scenario niet opnieuw doorgerekend.

Een belangrijk modelresultaat is hoe het getij van invloed is op het zuurstofarme areaal bij de bodem. Als indicator hiervoor wordt het areaal dat langer dan 7 aaneengesloten dagen een zuurstofconcentratie lager dan $3 \mathrm{mg} / \mathrm{l}$ heeft gebruikt. Figuur 15 toont de arealen voor de berekende scenario's. In het figuur zijn de scenario's geordend naar toenemend getij. Bij een getij van $30 \mathrm{~cm}$ treedt een halvering van het zuurstofarme areaal op. Met $50 \mathrm{~cm}$ getij neemt het zuurstofarme areaal nog verder af. Bij zeespiegelstijging neemt het zuurstofarme areaal iets toe, vermoedelijk omdat de diepte van het meer toeneemt.

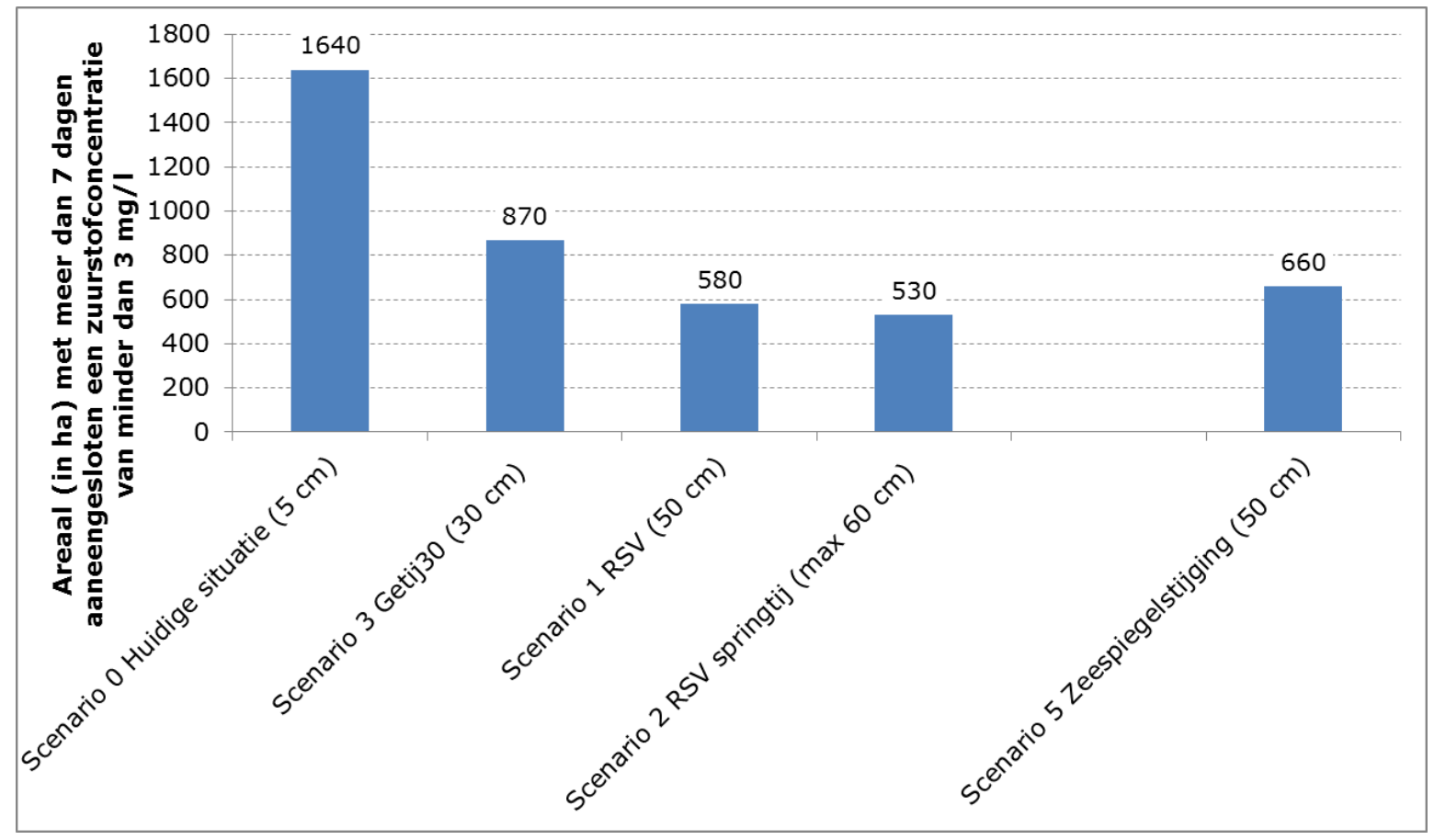

Figuur 15. Zuurstofarme areaal nabij de bodem per scenario uitgaande van areaal dat langer dan 7 aaneengesloten dagen een zuurstofconcentratie lager dan $3 \mathrm{mg} / \mathrm{l}$ heeft. NB: Scenario 0 Huidige situatie beschrijft het jaar 2008 en is dus zonder ingebruikname van de Flakkeese spuisluis.

Dit patroon komt overeen met eerdere scenariostudies zoals Nolte \& Spiteri (2011) en Nolte \& Lagendijk (2016) (Figuur 16). Nolte \& Lagendijk (2016) wordt het effect van de getijslag als volgt omschreven: "Hoe groter de getijslag, hoe kleiner het zuurstofarme bodemareaal. Tussen $40 \mathrm{~cm}$ en $60 \mathrm{~cm}$ getij treedt een afvlakking op, hetgeen erop duidt dat een verdere toename van de getijslag nog maar in een beperkte verbetering resulteert. Anders gezegd, de grootste verbetering wordt bereikt bij een toename 
van de getijslag tot circa $40 \mathrm{~cm}$. De reden hiervoor is dat niet veel getijdynamiek nodig is om de geringe stratificatie op te breken en voldoende menging te genereren om de zuurstofconcentratie in de onderlaag op niveau te houden. Meer getij leidt tot meer menging, maar niet meer tot een wezenlijk hogere zuurstofconcentratie. Er blijft echter een klein deel van het bodemareaal - namelijk de diepste delen die pas bij veel dynamiek volledig mengen - waar zuurstofarme condities kunnen blijven optreden. Het betreft zo'n 3\% van het bodemareaal, wat erop neerkomt dat met $50 \mathrm{~cm}$ getij minimaal zo'n $60 \%$ verbetering van de zuurstofhuishouding optreedt en het streefbeeld van maximaal 5\% zuurstofarm areaal gehaald wordt."

In Nolte \& Lagendijk (2016) wordt de onzekerheid in de modelresultaten als volgt beschreven: "Op basis van de beschikbare kennis gebaseerd op modelberekeningen is niet met zekerheid aan te geven hoeveel getij er nodig is om ervoor te zorgen dat in alle jaren (dat wil zeggen onder alle meteorologische condities) aan het streefbeeld wordt voldaan. In sommige jaren met veel wind en lage zomertemperaturen zou $25 \mathrm{~cm}$ getij genoeg kunnen zijn, terwijl in andere jaren met weinig wind en hoge zomertemperaturen $50 \mathrm{~cm}$ getij nodig is. Het uitgangspunt van $50 \mathrm{~cm}$ getij bevat daarom een onzekerheidsmarge om het risico op het niet halen van het streefbeeld klein te houden. $50 \mathrm{~cm}$ getij is echter geen garantie dat zuurstofarme condities nooit meer zullen voorkomen."

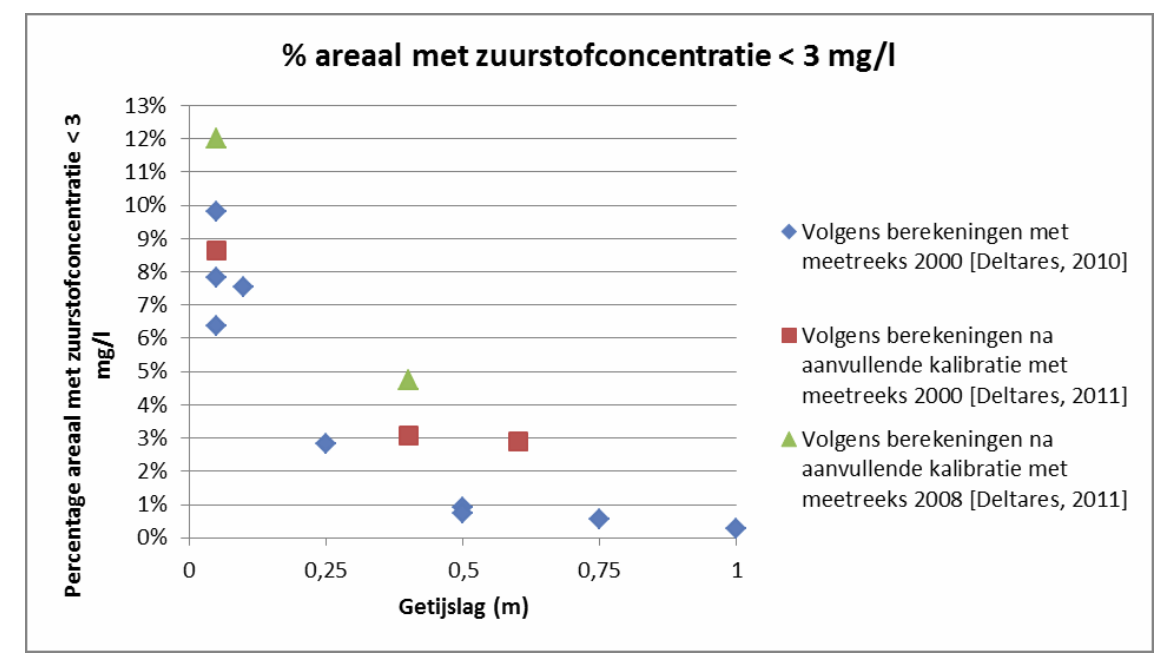

Figuur 16. Berekend percentage areaal met lage zuurstofconcentratie bij verschillende getijslag. Na een relatief snelle afname, ontstaat een afvlakking bij een toenemende getijslag. Figuur overgenomen uit Nolte \& Lagendijk (2016).

Het zuurstofarme areaal komt voor in de diepe geulen en diepe putten (Figuur 17). In het scenario Huidige situatie (maar zonder Flakkeese spuisluis) is een groot deel van de diepe geul langdurig zuurstofarm. Bij $30 \mathrm{~cm}$ getij is het zuurstofarme areaal bij Dreischor verminderd, maar nog wel aanwezig. De zuurstofarme periode is korter. $\mathrm{Bij} 50 \mathrm{~cm}$ getij en meer is het zuurstofarme areaal beperkt tot de diepe putten ten oosten van de Bouwerssluis bij Scharendijke en Den Osse. 


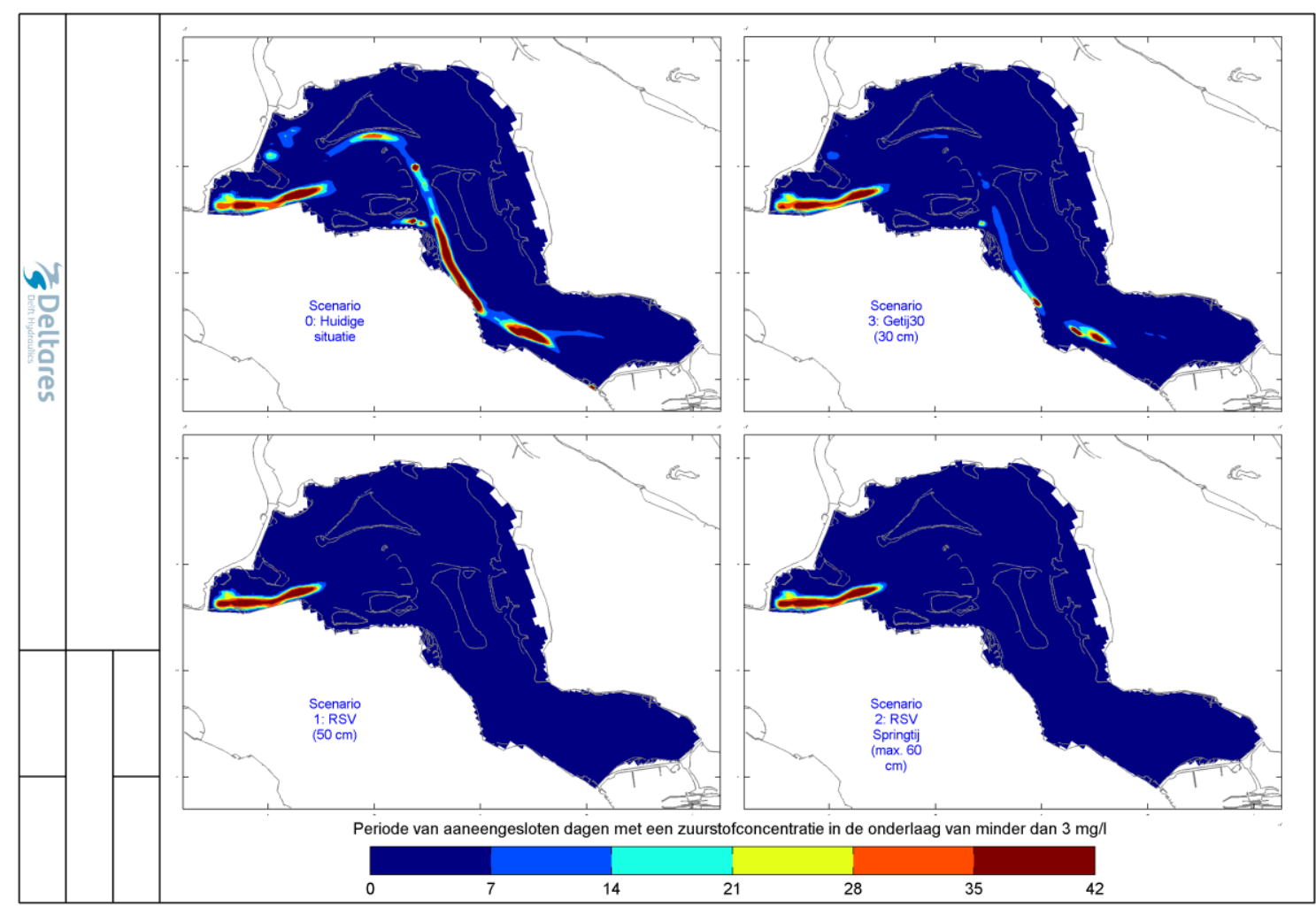

Figuur 17. Voorkomen zuurstofarm areaal nabij de bodem in de diepe delen. NB: Scenario 0 Huidige situatie beschrijft het jaar 2008 en is dus zonder ingebruikname van de Flakkeese spuisluis.

Tabel 10 toont enkele kentallen voor de waterkwaliteit. Het gemodelleerde effect van een toename van de primaire productie en de chlorofyl-a concentraties bij het toelaten van een gedempt getij in het Grevelingenmeer kan verklaard worden door de toename van de beschikbaarheid van stikstof. In de huidige situatie is primaire productie in het Grevelingenmeer stikstof-gelimiteerd in het late voorjaar en de zomer (mei-augustus). In het vroege voorjaar (april) kan korte tijd fosfaat-limitatie voorkomen. Zowel in de Voordelta als in de Oosterschelde is de stikstofconcentratie (iets) hoger dan in het Grevelingenmeer. Door de toenemende uitwisseling met Voordelta en Oosterschelde is meer stikstof beschikbaar voor algengroei. $\mathrm{Bij} 30 \mathrm{~cm}$ getij is het concentratieverschil tussen Voordelta en Oosterschelde en het Grevelingenmeer al zodanig afgenomen, dat meer getij nog maar een relatief kleine verdere toename laat zien. In deze modelberekeningen is het effect van extra begrazing door schelpdieren (die profiteren van een toename in primaire productie) slechts op eenvoudige wijze meegenomen. De concentratie zou hierdoor wat verlaagd kunnen worden. Ook is geen rekening gehouden met autonome ontwikkeling van de stikstofconcentratie in de Noordzee, ofwel de aanvoer via Rijn en Schelde. Deze autonome ontwikkeling heeft echter een gelijk effect op wel of niet een doorlaat en is daardoor niet onderscheidend.

Tabel 10. Kentallen voor waterkwaliteit per scenario.

\begin{tabular}{|c|c|c|c|c|c|c|}
\hline Parameter & Statistiek & 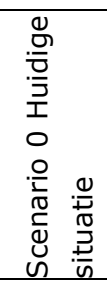 & 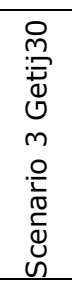 & 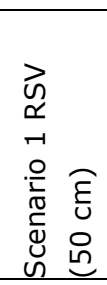 & 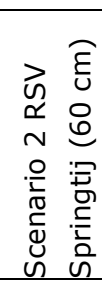 & 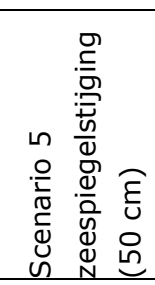 \\
\hline Primaire productie $\left(\mathrm{gC} / \mathrm{m}^{2} / \mathrm{j}\right)$ & $\begin{array}{l}\text { Gemiddeld over hele } \\
\text { meer }\end{array}$ & 252 & 422 & 453 & 455 & 492 \\
\hline $\begin{array}{l}\text { Chlorofyll-a concentratie } \\
\left(\mathrm{mg} / \mathrm{m}^{3}\right)\end{array}$ & \multirow{3}{*}{$\begin{array}{l}\text { Dreischor, bij } \\
\text { oppervlak, } \\
\text { jaargemiddeld }\end{array}$} & 4,8 & 7,1 & 7,7 & 7,9 & 8,0 \\
\hline Totaal zwevend stof $\left(\mathrm{g} / \mathrm{m}^{3}\right)$ & & 5,4 & 6,1 & 6,3 & 6,3 & 6,4 \\
\hline Doorzicht (m) & & 2,3 & 2,1 & 2,1 & 2,1 & 2,1 \\
\hline
\end{tabular}


De zwevend stof concentratie neemt in de modelberekeningen iets toe en het doorzicht neemt iets af bij toelaten van een gedempt getij in het Grevelingenmeer. Hoewel de richting overeenkomt met de verwachting, is de grootte van de respectievelijke toename en afname onzeker. In het model is de import van zwevend stof en de erosie van slibrijk materiaal dat zich in diepe geulen in de loop der jaren heeft verzameld niet meegenomen. 


\section{Toekomstige ontwikkeling natuurwaarden}

\subsection{Autonome ontwikkeling natuurwaarden}

\section{Eilanden en oevers}

\section{Overgangsvegetaties: vochtige duinvalleien en zilte vegetaties}

Duinvalleivegetaties gaan van nature als gevolg van successie en geleidelijke ontkalking vrij snel over in wilgenstruwelen, duindoornstruwelen en bos (Van de Haterd et al. 2010). Echter, indien er een intensief beheer wordt gevoerd, zoals bijvoorbeeld op de Slikken van Flakkee Zuid, Veermansplaat en De Hompelvoet, kunnen deze begroeiingen decennialang standhouden. Ontkalking treedt met name op in de delen waar infiltratie van regenwater kan plaatsvinden en niet in de laaggelegen vochtige delen waar het grondwater hoog in het maaiveld staat. Deze plekken zijn momenteel veelal begroeid met jonge duinvalleivegetaties, al dan niet met groenknolorchis. Daarnaast wordt een groot aantal platen in het Grevelingenmeer begraasd en/of gemaaid om de successie te vertragen. Dit lijkt mede succesvol, omdat de ontkalking in de relatief fijne zanden langzaam verloopt (Van de Haterd et al. 2010). Bij voortzetting van het huidige beheer van begrazing en maaien is de verwachting dat de vochtige duinvalleivegetaties bij een goed beheer nog heel lang kunnen voortbestaan ( $>50$ jaar). Dit is ingeschat op basis van expertoordeel. Zolang de bodem gebufferd blijft door aanwezigheid van kalk of aanvoer daarvan door kalkrijke kwel, zoutspray of zeer incidentele overspoeling kunnen de soorten van kalkrijke duinvalleien blijven voorkomen (zoals bv. op het 300 jaar oude Kapenglop op Schiermonnikoog). In het onderzoek van Van de Haterd et al. (2010) en daarin vermelde bronnen wordt aangegeven dat vochtige duinvalleivegetaties op den duur zullen verouderen waarbij de groenknolorchis sterk afneemt of verdwijnt. De ontwikkeling van een pioniergemeenschap naar oudere stadia van het knopbiesverbond duurt meestal circa 20-30 jaar, maar in sommige situaties kunnen pioniersituaties wel 60 jaar standhouden. Inventarisatie van de Kraker in 2016, dus 46 jaar na afsluiten van de Grevelingen, laat zien dat de groenknolorchis nog in groten getale voorkomt, voornamelijk op de Veermansplaat, en dat nog geen sprake lijkt te zijn van afname door successie. De populatie is zich juist verder aan het opbouwen. De duinvallei-vegetaties met Groenknolorchis lijken robuust door voortdurende en ononderbroken aanvoer van kalkrijke kwel en het gevoerde beheer. Hoe lang deze vegetaties nog exact in deze samenstelling (met groenknolorchis) kunnen voorkomen, is lastig te zeggen. De vegetatie zal op termijn door geleidelijke ontkalking en bodemvorming over gaan in andere, korte graslanden die eveneens soortenrijk kunnen zijn en eveneens grote natuurwaarde hebben (de precieze ontwikkeling in de Grevelingen is moeilijk te voorspellen, maar gedacht moet worden aan de omvorming naar heischrale graslanden van het Europees beschermd habitattype 6230).

Zilte vegetaties komen voor op en langs de randen van voormalige slikken en platen. De autonome ontwikkeling van deze vegetaties wordt beïnvloed door de ontzilting van de oever. Door neerslag ontzilt de bodem van de platen en slikken. De zilte vegetaties zullen in de toekomst met voortzetting van het huidige beheer nog iets afnemen als gevolg van het geleidelijk verzoeten van de oever. De zoetwaterlens groeit nog steeds langzaam naar de oever toe en drukt het zoute water weg. Tegen de rand van het zoute water van het meer blijft de invloed van zout water aanwezig via zoutspray, incidentele overspoeling (tijdens storm) en/of capillaire opstijging. Hier treedt geen ontzilting op en daardoor ook nauwelijks successie; zilte vegetaties blijven hier aanwezig. Naast ontzilting speelt ook de voortschrijdende erosie van de oevers een rol bij de niet direct verdedigde oevers. Bij geheel niet verdedigde oevers bedraagt de erosie ongeveer twee meter per jaar, op indirect verdedigde één meter per jaar (De Jong \& Van Maldegem, 2010). Hierdoor eroderen zilte pioniervegetaties, die slechts gedeeltelijk kunnen opschuiven vanwege het hoger liggende achterland. In de paragraaf hieronder wordt hier dieper op ingegaan.

\section{Oevererosie/zandhonger}

Onder invloed van golven vindt geleidelijke erosie van de zandige oevers plaats. De autonome ontwikkeling van oevererosie in het Grevelingenmeer is ingeschat door De Jong en Van Maldegem (2010). Door verdwijnen van de opbouwende krachten van het getij uit het Grevelingenmeer is zandhonger ontstaan en verdwijnt het sediment vanuit de ondiepe vooroever langzaam naar de diepere 
delen van de vooroever en uiteindelijk in de geulen. Oevererosie van onverdedigde oevers treedt op, doordat bij het vaste waterpeil de golfaanval altijd op dezelfde hoogte plaatsvindt. Na afsluiting van het Grevelingenmeer is hierdoor in de perioden 1980-1990 en 1990-2001 respectievelijk 44 en 55 ha drooggevallen gebied geërodeerd. Bij de onverdedigde oevers is sprake van een nog steeds doorgaande erosie. De oeverlijn treedt terug met snelheden die variëren afhankelijk van de ligging op de overheersende wind- en golfrichting. Op de Slikken van Flakkee is dat ca 2 tot $3 \mathrm{~m}$ per jaar en op de Hompelvoet een stuk minder.

Op de vooroever treedt erosie en vervlakking op door golfwerking tot circa $2 \mathrm{~m}$ onder het wateroppervlak. Als deze nieuwe evenwichtsdiepte is bereikt, wordt verwacht dat erosie stopt, omdat de golfwerking niet dieper doordringt. De vooroever verdiept zich nog steeds met 1 tot $2 \mathrm{~cm}$ per jaar. Bij verdedigde oevers treedt ook verdieping op van het voorland tot een evenwichtssituatie is bereikt. Voor meer informatie zie De Jong en Van Maldegem (2010). Tenslotte wordt opgemerkt dat oevererosie erg afhankelijk is van de specifieke situatie, waarbij wel of geen oeververdediging en de wijze van oeververdediging van belang zijn naast de oriëntatie op de overheersende windrichting.

\section{Broedvogels}

Het peilbeheer in de huidige situatie (met een $6 \mathrm{~cm}$ lager zomerpeil dan winterpeil) zorgt ervoor dat foerageer- en broedgebieden voor grondbroedende kustbroedvogels beschikbaar komen. De vogels kunnen tevens veiliger broeden met een verminderd risico dat de nesten onderlopen bij windopzet. Het lagere peil zorgt ook voor een verbeterde drainage waardoor het regenwater beter weg kan en de kans kleiner is dat de nesten onderlopen door plasvorming bij hevige regenval. Een selecte groep van soorten zoals de Dwergstern en Kluut broeden op de hogere delen in de zone die net droogvalt. Dit heeft met de vereiste openheid of spaarzame begroeiing te maken die deze soorten prefereren. Het Grevelingenmeer is, zelfs 45 jaar na afsluiting, nog steeds een waardevol gebied voor grondbroedende vogels. De verwachting is dat bij continuering van het huidige beheer, de broedgebieden nog lang in stand kunnen worden gehouden. Sommige delen zijn echter te begroeid geraakt, zoals bijvoorbeeld de Hompelvoet, om te fungeren als geschikt broedgebied. Beheer blijft daarom noodzakelijk. Daarnaast vormt de opkomst van predatoren zoals de vos en roofvogels een bedreiging voor broedvogels waardoor sommige gebieden in de toekomst mogelijk minder geschikt zijn om te broeden.

\section{Zoogdieren: de Noordse Woelmuis}

Het voorkomen van de Noordse Woelmuis wordt jaarlijks onderzocht door de Kraker (2017). Het leefgebied van de Noordse Woelmuis staat onder druk, waarbij met name de (mogelijke) komst van concurrerende soorten zorgen baart (de Kraker 2017). Door de Kraker (2017) worden verschillende suggesties gedaan om het vegetatiebeheer voor deze soort te optimaliseren.

\section{Open water (watersysteem)}

Hier wordt ingegaan op de mogelijke autonome ontwikkeling van het openwaterecosysteem en de doorwerking daarvan op natuurwaarden. De gevolgen op de verschillende soortengroepen worden op hoofdlijnen besproken.

\section{Waterkwaliteit, Zuurstofloosheid en bodemleven}

De autonome ontwikkeling van de zuurstofhuishouding is ingeschat op basis van literatuur en op basis van expertoordeel. Daarbij is ook gebruik gemaakt van expertoordeel van deskundigen van Bureau Waardenburg (zie interview in Bijlage $\mathrm{H}$ ). Bij gelijkblijvende temperaturen zal de optredende zuurstofloosheid in de zomers niet verergeren. Als er vaker warme perioden zullen optreden (door klimaatverandering) wordt het probleem erger, is sterfte van het bodemleven steeds ondieper te verwachten en zullen zuurstofloze condities langer aanhouden. De neerwaartse trend van biomassa van bodemdiergemeenschappen in de ondiepe zone die vanaf 1990 wordt gerapporteerd (Sistermans et al. 2006; Kater \& Van Onselen 2013) is vermoedelijk niet direct gerelateerd aan het optreden van zuurstofloosheid (zuurstofloosheid treedt ruwweg op vanaf 5 meter waterdiepte), maar aan de afname van stroomsnelheden en dynamiek. Het is onduidelijk of deze trend zich in de toekomst zal voorzetten.

In de winter van 2017 is de Flakkeese Spuisluis geopend die zorgt voor waterverversing in het oostelijk deel van het Grevelingenmeer. Een eerste visuele inventarisatie van de bodem in het oostelijk deel laat een duidelijke ecologische verbetering zien in vergelijking met de situatie vlak voor de opening 
(Didderen et al. 2016; Didderen \& Driessen 2017) met minder schade aan het bodemleven, lagere bedekking van bacteriematten, hogere soortenrijkdom en lokaal voorkomen van mosselbroed (dit kan alleen bij relatief goede zuurstofcondities). Dit beeld wordt bevestigd door een proef met overleving en groei van mosselen voor en na opening van de Flakkeese Spuisluis (Wijsman et al. 2016; Wijsman et al. 2017). De groei en ontwikkeling van de mosselen zijn een goede indicator voor de waterkwaliteit en -productiviteit. De resultaten suggereren een aanzienlijke verbetering van de waterkwaliteit in de omgeving van de Flakkeese Spuisluis. Deze eerste proef en waarnemingen wijzen op een positieve ontwikkeling in het oostelijk deel van het Grevelingenmeer ten aanzien van zuurstofcondities voor bodemleven.

Van de overige waterkwaliteitsparameters is voor zover bekend geen inschatting van de autonome ontwikkeling bekend. Op basis van onze inschatting in dit rapport worden voor de nutriënten geen grote ontwikkelingen voorzien. Fosfaat is een mogelijke uitzondering, omdat daarin voor de meeste deltawateren een dalende trend is geconstateerd (bijv. De Vries, 2015). Nolte en Lagendijk (2016) beschrijven als algemene kennisvraag hoe de fosfaathuishouding in de Nederlandse wateren zich over de komende jaren tot decennia ontwikkelt en of er op een gegeven moment een omslag van stikstoflimitatie naar fosfaatlimitatie zal optreden.

\section{Vissen en watervogels}

Voor het inschatten van de autonome ontwikkeling van vissen en watervogels is gebruik gemaakt van de aanvulling op de natuureffecten studie en MER waarin de autonome ontwikkeling in relatie tot Natura 2000-doelen wordt besproken (RoyalHaskoning DHV 2017) (zie Bijlage I Natura 2000 doelstellingen). Hier wordt beknopt de verwachte autonome ontwikkeling geschetst aan de hand van deze studie.

Ten aanzien van de vissen wordt geen verdere achteruitgang in het aantal soorten verwacht, maar door de mogelijk verslechterende zuurstofcondities wordt wel een achteruitgang van de biomassa van, in het bijzonder bodembewonende, vissen verwacht. Hoe groter het zuurstofloze bodemoppervlak hoe kleiner hun habitat. In het oostelijke deel zullen vissen profiteren van de ingebruikname van de Flakkeese spuisluis. Eerste resultaten van visstandsbemonsteringen voor en na de opening van de sluis bevestigen dit (Hop 2016; Hop 2017) (zie paragraaf 4.3). De verwachting is dat dit ook een gunstig effect zal hebben voor sommige vissoorten in het Grevelingenmeer. Dit is dan weer gunstig voor sommige soorten visetende vogels zoals de kleine zilverreiger waarvan de aantallen de afgelopen jaren zijn achtergebleven (wegens strenge winters) bij de gestelde doelen (Ministerie van Infrastructuur en Milieu, 2015 , 2016). Voor visetende vogels worden in de autonome ontwikkeling met voortzetting van huidig beheer geen knelpunten verwacht. Op basis van aanvulling op de natuureffectenstudie (RoyalHaskoningDHV, 2017) is het echter de verwachting dat de gestelde doelen voor fuut, geoorde fuut, kleine zilverreiger en lepelaar waarschijnlijk niet gehaald worden en het voor kuifduiker en aalscholver onduidelijk is. Dit vergt nader onderzoek.

Voor bodemdieretende vogels is ook de mogelijke verergering van de zuurstofloosheidproblematiek een knelpunt. Voor de brilduiker zullen hierdoor de foerageermogelijkheden afnemen. Ook voor steltlopers zoals scholekster is de verwachting dat de doelen niet gehaald worden.

Voor wat betreft de groep van de planteneters is de verwachting dat de aantallen ganzen en zwanen de komende jaren stabiel blijven, omdat ze voor een belangrijk deel in aanpalend agrarisch gebied foerageren, waarvoor geen veranderingen worden verwacht. Soorten die op het schor foerageren zoals smient, wintertaling en wilde eend zullen met de verdergaande ontzilting van de oeverzone mogelijk verder achteruitgaan.

\section{Zeegras}

Groot zeegras is reeds geruime tijd uit het Grevelingenmeer verdwenen. Rijkswaterstaat is een pilot gestart met het aanplanten van zeegras in het Grevelingenmeer. Als dit succesvol is dan kan dit de voedselbeschikbaarheid voor waterplanten etende vogels verbeteren.

\section{Zeezoogdieren}

Arts et al. (2017) laat een positieve trend zien voor de Gewone zeehond in het Deltagebied. In de Grevelingen wordt dezelfde trend waargenomen. Ook de Grijze zeehond laat een positieve trend zien in het Deltagebied, echter in de Grevelingen is het aantal individuen te laag $(<5)$ om uitspraak te doen over een mogelijke trend. 


\subsection{Verandering van het watersysteem in een getijdesituatie}

\section{De rol van slib in een getijdesituatie}

Over de rol van slib en mogelijke vertroebeling in het Grevelingenmeer in een situatie met gedempt getij is de afgelopen jaren discussie geweest. In een zienswijze ingebracht door Prof. Filip Meysman (NIOZ) wordt het volgende gesteld: als gevolg van sedimentatie van organisch rijk slib vanuit de Noordzee heeft zich een sliblaag opgebouwd tot enkele meters dik in de diepe westelijke geulen die dunner wordt naar het oosten toe. Door toelaten van getij wordt deze sliblaag gemobiliseerd en zal een zeer sterke vertroebeling optreden met in het ergste geval verslechtering van de waterkwaliteit (sterk verminderd doorzicht, hoge nutriëntenconcentraties en een grote zuurstofvraag met zuurstofloosheid als gevolg). Mogelijk blijft het slib langdurig in suspensie doordat het maar beperkt wordt afgevoerd. In de MER en de daaraan ten grondslag liggende onderzoeken is geen rekening gehouden met de rol van slib en mogelijke verslechtering van de waterkwaliteit in een getijdesituatie.

Naar aanleiding van deze zienswijze heeft Deltares een aanvullende analyse uitgevoerd in opdracht van Rijkswaterstaat waarbij aan de hand van bodemmonsters de kritische bodemschuifspanning is bepaald die nodig is om het slib in resuspensie te brengen. Volgens de hydrodynamische modellen wordt de kritische bodemschuifspanning bij $50 \mathrm{~cm}$ getij via de nieuwe doorlaat op weinig plekken in het Grevelingenmeer overschreden (Van Kessel et al. 2015). Het water kan na ingebruikname van het doorlaatmiddel wel tijdelijk troebeler worden maar de verwachting is dat dit enkele weken duurt en niet langdurig zal zijn. Ook zal er hierbij geen sterke vertroebeling optreden zoals in de zienswijze wordt gesteld maar gaat het om zwevend stof van enkele tientallen $\mathrm{mg} / \mathrm{l}$. Door de doorlaat bij ingebruikname geleidelijk te openen kan vertroebeling nog extra beperkt worden. De conclusie dat het risico op langdurige vertroebeling van het systeem door opwerveling van bodemslib klein is, is later bevestigd door verschillende experts (Houtekamer en Van Kleef, 2016).

\section{Verwachting doorwerking in het voedselweb}

Op basis van de modellering wordt voorspeld dat er een aanzienlijke stijging in primaire productie (algen) gaat plaatsvinden van $252 \mathrm{~g} \mathrm{C} / \mathrm{m}^{2} / \mathrm{j}$ in de huidige situatie naar $422-492 \mathrm{~g} \mathrm{C} / \mathrm{m}^{2} / \mathrm{j}$ in de gemodelleerde scenario's in een situatie met $30-50 \mathrm{~cm}$ getij (paragraaf 5.4 ). De algen vormen als primaire producenten het laagste trofische niveau in het voedselweb en vormen het voedsel voor primaire consumenten zoals zoöplankton, bodemdieren en sommige vissoorten. De vraag is aan welke soorten/soortengroepen deze toename aan algenproductie het meest ten goede zal komen. Deze vraag is bediscussieerd in de expertsessie (Bijlage G). Daarnaast zijn ook experts van Bureau Waardenburg geïnterviewd over dit onderwerp (Bijlage $\mathrm{H})$.

Van belang is om te benadrukken dat de soortensamenstelling van het fytoplankton in belangrijke mate bepaalt voor welke soorten het een voedselbron kan vormen. Het is moeilijk te voorspellen hoe de fytoplanktonsoortensamenstelling er uit zal gaan zien. Dit hangt ook samen met de waterbeweging. In stilstaand water ontwikkelen over het algemeen kleinere algencellen die weer bepalend zijn voor ontwikkeling van bepaalde zoöplanktonsoorten die weer bepalend zijn als voedsel voor vissen. Dit zijn complexe interacties en zijn daarom lastig te voorspellen. De laatste jaren is de soortensamenstelling van het fytoplankton niet meer bepaald in het Grevelingenmeer. In het verleden zijn wel soortengroepen bepaald (Wetsteijn 2011).

\section{Zoöplankton en bodemdieren}

De verwachting is dat de toename in algen, tezamen met een grotere waterbeweging, voornamelijk ten goede komt aan filtrerende bodemdieren en in het bijzonder de schelpdieren (Japanse oester, Platte oester, etc.) maar ook andere soorten filterfeeders zoals zakpijpen, sponzen, (rib)kwallen en anemonensoorten kunnen hiervan profiteren. Door toename in waterbeweging komen deze algen ook beter beschikbaar voor bodemdieren en daarnaast zorgen de verbeterde zuurstofcondities ervoor dat er een (veel) groter areaal leefgebied beschikbaar is. De waterbeweging zal er ook voor zorgen dat het organisch materiaal meer wordt verspreid. Dit kan opgenomen worden door zoöplankton of het zakt uit naar het sediment waar het opgenomen wordt door bodemdieren.

Vissen

Over de verwachte veranderingen in visstand zijn experts niet helemaal eensgezind. Enerzijds is de verwachting dat de toename van bentische filterfeeders ten koste gaat van het zoöplankton vanwege 
concurrentie om algen. Zoöplankton is een belangrijke voedselbron voor veel (voornamelijk pelagische) vissoorten. Daarom is er geen reden om aan te nemen dat de visstand sterk zal toenemen bij invoering van getij. De visstand in huidige situatie laat zien dat marien (juveniele) vissoorten als Haring en Sprot, die het grootste deel van de visbiomassa bepalen voornamelijk in het voorjaar, vooral voorkomen in het westen in de omgeving van de Brouwerssluis en over het algemeen niet verder naar het oosten trekken (Hop 2016). Als de verwachting is dat zoöplankton niet sterk zal toenemen is er geen reden om aan te nemen dat mariene soorten verder het meer op trekken en in grotere aantallen voor zullen komen.

Anderzijds zal door het vergroten van de connectiviteit met de Noordzee door het doorlaatmiddel in het noordelijk deel van de Brouwersdam er meer mariene vissoorten het Grevelingenmeer inzwemmen (mits het doorlaatmiddel vismigreerbaar is). Naast haring en sprot zijn dit bijvoorbeeld ook makreel en zeebaars. Ook zal het Noordzeewater wat naar binnen spoelt zoöplankton bevatten dat als voedsel kan dienen voor vissen.

De bodemvissen vormen ook een belangrijke groep in het Grevelingenmeer en, hoewel beperkt in biomassa vergeleken met haring en sprot, vertegenwoordigen ze de grootste soortenrijkdom. Bodemvissen zullen profiteren van de verbeterde zuurstofcondities op de bodem en daarmee het bodemleven waardoor hun leef- en foerageergebied groter wordt. Een eerste inventarisatie van de bodem in de omgeving van de Flakkeese Spuisluis toont het voorkomen van (grote getale) harder, kornaarsvis en tweevlekgrondel aan. Een eerste inventarisatie van de visstand in 2017 toont aan dat de hoogste aantallen vissensoorten in de omgeving van de Flakkeese Spuisluis worden aangetroffen met aanwezigheid van soorten als glasgrondel, Lozano's grondel, zeedonderpad, schar, schol, steenbolk en wijting terwijl dit in 2016 nog niet zo was (Hop 2017). Op basis hiervan is de verwachting dat in een situatie met gedempt getij het aantal en mogelijk ook het aantal soorten bodemvissen zal toenemen doordat het Grevelingenmeer als geheel een geschikter leefgebied wordt voor bodemvissen.

\section{Visetende vogels}

Uiteraard hangt de verwachte ontwikkeling van visetende vogels sterk samen met de visstand en is het onzeker hoe aantallen zich precies gaan ontwikkelen. In de huidige situatie foerageren de grote sterns die op de eilanden broeden, niet in het Grevelingenmeer maar in de Voordelta. Dwergsterns en in mindere mate visdieven jagen wel op vis in de bovenste waterlaag van het Grevelingenmeer. Een mogelijke toename van aantallen zoals Haring en Sprot in het Grevelingenmeer zou voor deze soorten gunstig zijn qua voedselvoorziening en omdat ze minder ver hoeven te vliegen vanaf hun broedplaats. De verwachte toename in bodemvissen is in ieder geval gunstig voor soorten als fuut, geoorde fuut, kleine zilverreiger en lepelaar. Mogelijk is de verdere toename van de tweevlekgrondel die zeer talrijk is de afgelopen jaren (waarnemingen Bureau Waardenburg) gunstig voor visetende vogels, echter, er is nog weinig bekend over deze soort als voedsel voor visetende vogels.

\subsection{Ontwikkeling van intergetijdengebieden}

In een situatie met gedempt getij $(30-50 \mathrm{~cm})$ zal permanent intergetijdengebied ontwikkelen, met in totaal een behoorlijke oppervlakte (variërend van 800 ha in het scenario met $30 \mathrm{~cm}$ getij tot 1100 ha in het RVS $50 \mathrm{~cm}$ getij scenario). In het geval van de scenario's RSV Peilbeheer en RSV Zeespiegelstijging is het areaal permanent intergetijdengebied veel kleiner, in het geval van RSV Peilbeheer slechts 150 ha. De intergetijdengebieden ontwikkelen zich met name langs de slikken van Flakkee en de Veermansplaat. In deze paragraaf wordt het morfologisch functioneren van deze intergetijdengebieden met gedempt getij en de ecologische betekenis bediscussieerd aan de hand van wat er in de expertsessies naar voren is gekomen en bestaande literatuur.

\section{Gedempt getij en zandhonger}

De getijslag en de eb- en vloedfase zijn bepalend voor het sedimenttransport en daarmee sedimentatie en erosie van zand en slib. De erosie in een situatie van gedempt getij is eerder ingeschat in een studie van De Jong en Van Maldegem (2010). Op basis van deze studie is de verwachting dat in een situatie met een gedempt getij de opbouwende krachten (i.e. onder invloed van de getijstromingen) verwaarloosbaar zullen zijn vergeleken met de erosie die zal optreden (i.e. onder invloed van golfwerking). Het verschil in opbouwende krachten in getijslag van $30 \mathrm{~cm}$ vergeleken met $50 \mathrm{~cm}$ is hierbij vermoedelijk ook verwaarloosbaar. Dit proces van 'zandhonger' is vergelijkbaar met de erosieprocessen die in de Oosterschelde optreden. In een getijdesituatie zal de golfaanval in het intergetijdengebied 
variëren tussen hoog- en laagwater. De verwachting is dat de erosie met ongeveer dezelfde snelheid door zal gaan als in de huidige situatie met een stagnant peil. De erosie zal in het begin mogelijk sneller gaan en daarna geleidelijk wat verminderen totdat een nieuwe evenwichtssituatie wordt bereikt. Het type oever, verdedigd of niet, is daarbij zeer bepalend voor de mate en snelheid waarmee erosie zal optreden.

\section{Betekenis intergetijdengebieden als foerageergebied}

Tijdens bijeenkomsten met betrokkenen is de zorg uitgesproken over de verwachte kwaliteit van de intergetijdengebieden en mogelijk beperkte betekenis als foerageergebied omdat ze te zandig zullen zijn waardoor er mogelijk lage aantallen bodemdieren zullen gaan voorkomen. Met hulp van experts en ervaring uit onderzoek naar bodemdieren in intergetijdengebieden in de Oosterschelde en Westerschelde is een inschatting gemaakt van de te verwachten ontwikkeling.

Om te beginnen is de sedimentsamenstelling en het slibgehalte van de bodem niet de enige bepalende factor voor het voorkomen van bodemdieren maar is bijvoorbeeld ook de stroomsnelheid van het water, golfwerking en overspoelingsduur van belang. Zoals al eerder gesteld is de verwachting dat de stroomsnelheden relatief laag gaan zijn bij een gedempt getij en dat de intergetijdengebieden een in hoofdzaak laagdynamisch karakter zullen kennen, hoewel op meer geëxponeerde gebieden golfwerking wel een rol kan spelen. Vergelijkende studies tussen de Oosterschelde en de, meer slibrijke, Westerschelde laten zien dat sommige soorten bodemdieren daadwerkelijk gebonden zijn aan een hoger slibgehalte maar dat dezelfde soorten in de Oosterschelde kunnen voorkomen bij veel zandigere bodems dan in de Westerschelde en dat dit komt doordat stroomsnelheden in de Oosterschelde lager zijn (Cozzoli et al. 2016). Er zijn gespecialiseerde soorten die gebonden zijn aan slib, maar de meeste soorten hebben een brede tolerantie in relatie tot sedimentsamenstelling. Een zandige bodem kan daarmee nog steeds een rijk bodemleven bevatten. Dit wordt bevestigd door de resultaten van onderzoek naar bodemdieren in de Galgeplaat en Oesterdam suppleties in de Oosterschelde waar in relatief grofzandige delen zonder slib toch een grote soortenrijkdom en hoge biomassa's aan bv. Kokkels (Cerastoderma edule) en Nonnetjes (Limecola balthica) werd aangetroffen (o.a. van der Werf et al. 2015). De combinatie van andere factoren zoals stroomsnelheid, droogvalduur, voedsel (fytoplankton, microphytobenthos) spelen hier natuurlijk ook een belangrijke rol.

De verwachting is dat het bodemleven van het intergetijdengebied in het Grevelingenmeer van vergelijkbare samenstelling zal zijn als in de Oosterschelde. Schelpdieren zoals de kokkel kunnen profiteren van het getij door zich te vestigen op de intergetijdengebieden waar de predatie (door voornamelijk garnalen) lager zal zijn. Overigens kwamen in de Grevelingen grote aantallen kokkels voor in de jaren 60 van de vorige eeuw, vóór de Deltawerken (Wolff, 1973). Een kanttekening moet wel geplaatst worden bij delen waar nu (dichte) vegetatie staat. Deze vegetatie zal afsterven en er zal zich relatief veel organische materiaal in de bodem bevinden. Dit kan de vestiging van bodemdieren belemmeren.

Hiermee kunnen de permanente intergetijdengebieden als foerageergebied gaan fungeren voor bodemdier etende vogels zoals scholekster, wulp, bonte strandloper, kanoet, rosse grutto, zilverplevier, bontbekplevier, bergeend, etc. Belangrijk hierbij is wel dat de overspoelingsduur van deze gebieden niet te lang is. Steltlopers hebben voldoende tijd nodig om tijdens laag water in hun energiebehoefte te kunnen voldoen, met name in de winter en doortrekperiode.

Daarnaast is het intergetijdengebied gunstig als kraamkamerfunctie met geschikt habitat voor bijvoorbeeld opgroeiende platvis. Meeuwen kunnen mogelijk profiteren van introductie van getij omdat zij profiteren van het intergetijdengebied en met name voedsel op de droogvallende stenen oeververdedigingen (zie volgende paragraaf). De grotere meeuwensoorten (die meer algemeen zijn) vormen echter ook weer een bedreiging (predatie) voor bijvoorbeeld sternen.

\section{Intergetijdengebied in relatie tot oevertypen}

Het type oever (onverdedigd, direct/indirect of gecombineerd verdedigd, zie Figuur 9 en Tabel 6) is bepalend voor het type intergetijdengebied dat zal ontstaan: zacht substraat of een combinatie van zacht en hard substraat en een eerder luwe dan wel meer geexponeerde intertidale zone. Figuur 18 geeft een schematisch overzicht van de ecologische ontwikkeling van de intergetijdengebieden bij verschillende oevertypen in een situatie met $30-50 \mathrm{~cm}$ getijslag die is ingeschat met behulp van expertoordeel en op basis van de oeverprofielen van De Jong en Van Maldegem (2010). 
De onverdedigde oevers ( $29 \%$ van de totale oeverlengte) bevinden zich vooral langs de Slikken van Flakkee, delen van de Hompelvoet, het Slik van Sirjansland en Markenje. Bij de onverdedigde oevers zal in het laag- en middenlittoraal een zone kaal slik ontstaan met bodemfauna die van betekenis is voor foeragerende vogels. Aan de bovenzijde zal deze zone overgaan in open zilte pioniervegetatie met soorten als Kortarige zeekraal en Schorrenkruid. Afhankelijk van hoe de vegetatie zich ontwikkelt zal de erosie van deze begroeide zone daardoor wat langzamer gaan maar zal ook een erosieklifje kunnen ontstaan op de grens van vegetatie en kaal slik.

De oevers die indirect verdedigd zijn (13\% van de totale oeverlengte) bevinden zich langs het zuidelijk deel van de Slikken van Flakkee, Bommenede, Markenje en een klein deel van de Veermansplaat. De indirecte oeververdedigingen zorgen voor een luwe zone intergetijdengebied en ondiep water van betekenis als foerageergebied voor vogels. Ondiepwaterzones ontstaan indien de gebieden achter de indirecte oeververdedigingen niet snel genoeg kunnen ontwateren, maar naar verwachting zal grotendeels droogvallend slik ontstaan. Volgens De Jong en Van Maldegem (2010) is de verwachting dat dit gebied geleidelijk zal eroderen maar tijdens de expertsessie kwam naar voren dat sediment ook goed zou kunnen bezinken in de luwe zone achter de verdediging en netto sedimentatie op zal treden. Door verschil in hydro-dynamische condities van de luwe zone in vergelijking met een onverdedigde zone zal het sediment mogelijk van fijnere samenstelling zijn. Door de minder dynamische omstandigheden (minder golfwerking) zal naar verwachting een rijker bodemleven kunnen ontwikkelen met hogere dichtheden en biomassa's. Op de oeververdediging zelf ontstaat hardsubstraat intergetijdengebied met een typische hardsubstraat fauna en flora (zie hieronder).

Het grootse deel van de oevers van de Veermansplaat en een klein deel van de Hompelvoet zijn direct verdedigd ( $20 \%$ van de totale oeverlengte). Bij de direct verdedigde oevers zal de intergetijdenzone naar verwachting grotendeels op de harde verdediging vallen met een kleine reep aan droogvallend zacht substraat ervoor. Op dit hard substraat intergetijdengebied zal een hardsubstraatgemeenschap ontwikkelen met verschillende soorten wieren, zeepokken, Japanse oesters, etc. vergelijkbaar met de Oosterschelde. Slakken en krabbensoorten die zich met laag water schuilhouden tussen de stenen zijn interessant als voedselbron voor sommige vogelsoorten zoals meeuwen soorten en de Scholekster. Als er al droogvallend kaal slik ontstaat onderaan de oeververdediging dan zal dit naar verwachting onderhevig zijn aan erosie en mogelijk snel eroderen.

Een groot deel van de eilanden zijn gecombineerd verdedigd (38\% van de totale oeverlengte) met Hompelvoet, Stampersplaat, Dwars in de Weg, Veermansplaat en daarnaast een stukje van het zuidelijk deel van de Slikken van Flakkee. Bij de gecombineerd verdedigde oever zal een combinatie optreden van hard en (luw) zacht substraat intergetijdengebied en ondiep water (zie hiervoor).

\section{Ontwikkeling van schor ecotoop}

In het scenario 'RSV Springtij' wordt een gemodelleerde springtij-doodtij cyclus van $10 \mathrm{~cm}$ toegelaten. In de ecologie wordt de intergetijdenzone tussen GHWD en GHWS aangeduid als schor (zie paragraaf 3.2). Schorren ontwikkelen zich in luwe gebieden aan de randen van estuaria en zeearmen en worden gekenmerkt door een verticale zonering in vegetatie afhankelijk van de droogvalduur. Door de luwte kan slibrijk sediment bezinken, zodat de bodem ophoogt. Zodra de bodem rond Gemiddeld Hoog Water (GHW) is opgehoogd, vestigt zich pioniervegetatie, die in de loop van de tijd wordt opgevolgd door schorvegetatie. Zolang er genoeg sediment in het water aanwezig is, blijft het schor opslibben totdat deze het niveau van de hoogste stormvloeden bereikt (Temmerman et al. 2003). De ontwikkeling van een volwaardig geulenstelsel is van belang voor sedimenttransport.

De verwachting is dat zich in een situatie met een klein verschil tussen springtij en doodtij van $10 \mathrm{~cm}$ springtij-doodtij geen volwaardige schorren zullen ontwikkelen vanwege het ontbreken van een volwaardige getijslag met bij behorend sedimenttransport, vorming van een geulenstelsel en hoogeverschillen etc. Wel zal in dit gebied, en voornamelijk in de luwe en minder erosiegevoelige delen, een zone met pioniervegetatie ontwikkelen met soorten als Kortarige zeekraal en Schorrenkruid (Habitatrichtlijn-habitattype H1310). Op iets hogere, minder vaak overstroomde delen zal over beperkte oppervlakte een zilte vegetatie kunnen voorkomen (Habitatrichtlijn-habitattype 1330), ook zonder dat er sprake is van een goed functionerend schor-ecosysteem met de bovengenoemde kenmerken (krekenstelsel, sedimentatie- en erosieprocessen). Volgens het model gaat het overigens slechts om een kleine schorzone van zo'n 30 ha. 


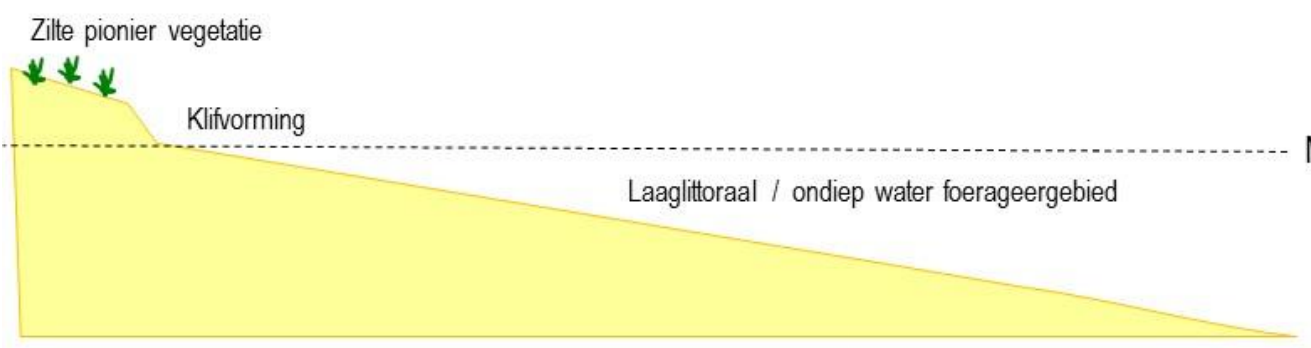

Middenpeil

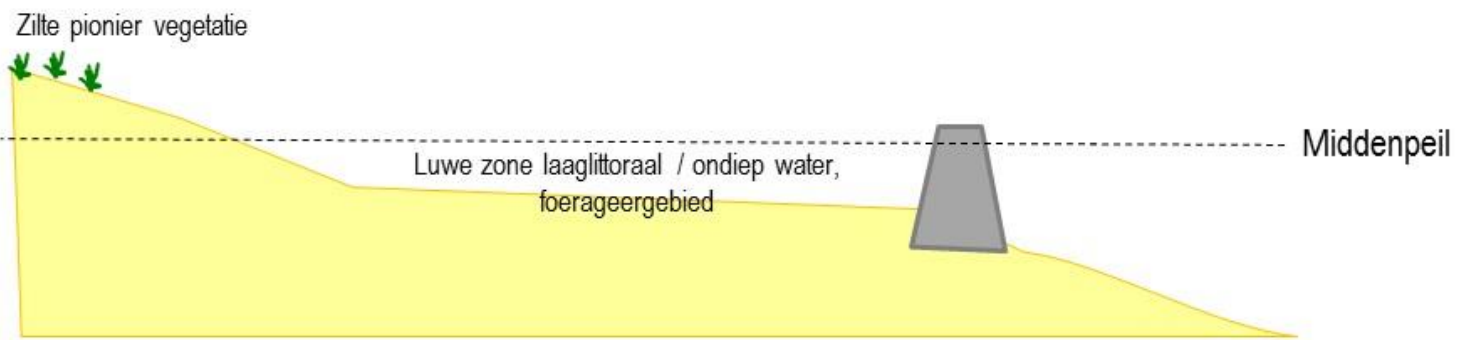

Zilte pionier vegetatie
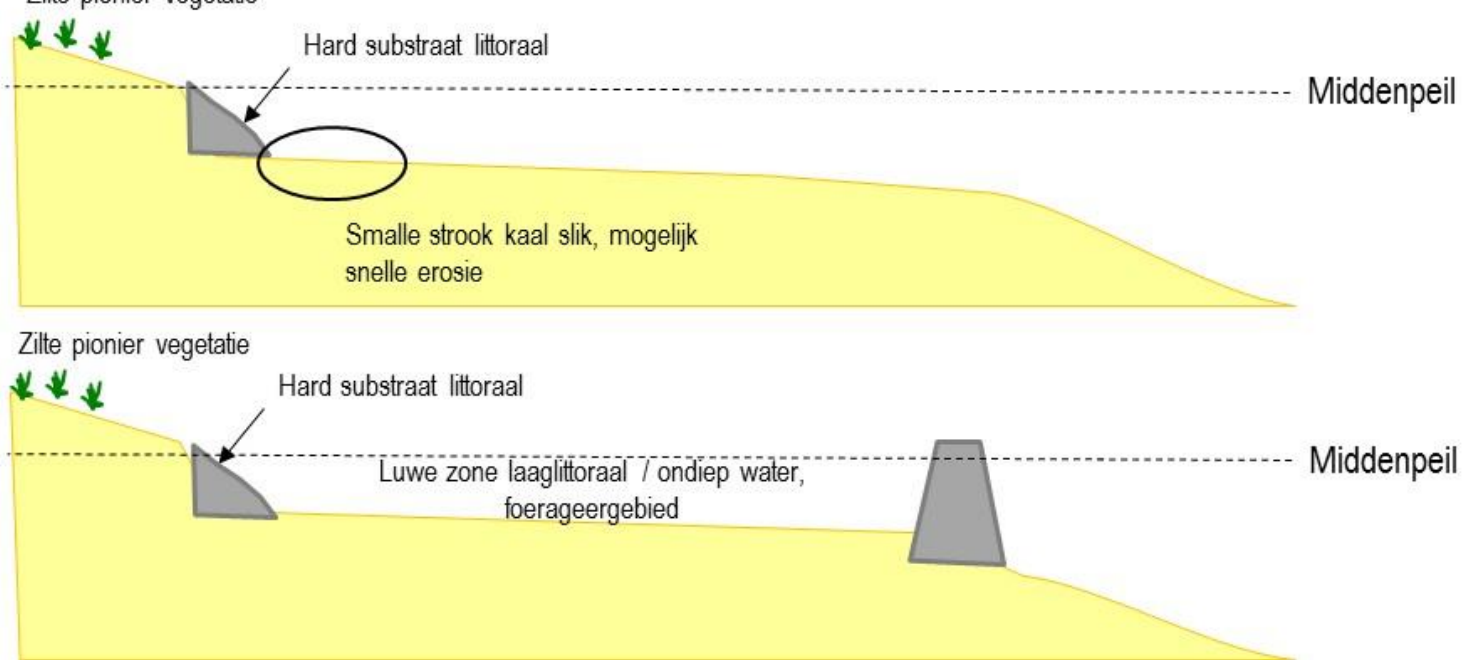

Figuur 18. Schematische weergave van de verwachten ecologische ontwikkeling van intergetijdengebieden in relatie tot oevertypen in een situatie met $30-50 \mathrm{~cm}$ getij bepaald op basis van expert oordeel en de oeverprofielen in de studie van De Jong en Van Maldegem (2010).

\section{Ecologische betekenis zomer- en winterintergetijdengebied}

Voor scenario 4 'RSV Peilbeheer' is een peilbeheer gemodelleerd waarbij het waterpeil in de zomermaanden (maart-sept) op -0,26 m NAP en in de wintermaanden (okt-feb) 0,36 m omhoog wordt gebracht naar +0,10 m NAP. De gevolgen van dit beheer voor terrestrische natuurwaarden en broedvogels worden besproken in paragraaf 6.4. Hier wordt ingegaan op de betekenis van deze gebieden voor bodemdieren, vissen en vogels.

Het 'winter intergetijdengebied' betreft een zone die in de zomer droog staat en in de winter intergetijdengebied is. Dit is ongunstig voor de ontwikkeling van mariene bodemdieren. De bodemdieren die zich in het winterhalfjaar ontwikkelen zullen afsterven en zich indien mogelijk verplaatsen nadat het waterpeil omlaag is gebracht. Overigens zullen er in het winterhalfjaar zich niet veel bodemdieren vestigen; de natuurlijke recruitment gebeurt met name in het late voorjaar en vroege zomer. Mogelijk profiteren vogels direct na het omlaag brengen van het peil tijdelijk van deze zone omdat ze kunnen foerageren op bodemdieren zonder dat het hoogwater wordt. Uiteraard is dit winter intergetijdengebied wel geschikt als broedgebied voor kustbroedvogels van kale gronden, vergelijkbaar met het zomer droog ecotoop in de huidige situatie (zie verder).

Het 'zomer intergetijdengebied' betreft een zone die in de zomer als intergetijdengebied fungeert en in de wintermaanden tot het ondiep water ecotoop gerekend kan worden. In de zomermaanden kan deze zone een waardevol foerageergebied voor vogels vormen, vergelijkbaar met de permanente intergetijdengebieden. In de winter kunnen de zeer ondiepe delen nog dienst doen als foerageergebied voor vogels en kan het gebied gebruikt worden door vissen. 


\subsection{Natuurwaarden eilanden en oevers in een getijdensituatie en mitigatiemogelijkheden}

Vegetatie

Voor het bediscussiëren van de effecten van getij op vegetatie ligt de focus op de gevolgen voor vochtige duinvalleivegetaties en zilte vegetaties (overgangsvegetaties) die zijn bediscussieerd m.b.v. expertoordeel (expertsessie) en gebruikmakend van eerdere studies. Daarnaast worden in deze paragraaf ook de effecten op andere Natura 2000-habitattypen ingeschat. Hierbij wordt ingegaan op H1310 zilte pionierbegroeïngen en $\mathrm{H} 2190$ vochtige duinvallei vegetaties - kalkrijk waarvan de mate van overspoeling in de verschillende scenario's staat aangegeven in paragraaf 5.3 en in bijlage N. De gevolgen hiervan en het mogelijk opschuiven van deze vegetaties wordt hieronder verder bediscussieerd.

\section{Gevolgen voor de zoetwaterbel (grondwater) op basis van expert oordeel}

Het voorkomen van duinvalleivegetaties is sterk afhankelijk van de beschikbaarheid van kalkrijk grondwater boven of dicht bij het maaiveld gedurende een groot deel van het jaar. Peilwisselingen door introductie van getij of peilbeheer zullen de zoetwaterbel die aanwezig is in de bodem van de eilanden en oevers beïnvloeden. Hier spelen verschillende processen een rol die beschreven zijn aan de hand van een expertoordeel door Perry de Louw (Deltares) en de Natuur Effecten Studie (RoyalHaskoning DHV 2017).

Als er (significante) delen van de oevers overspoeld raken tijdens hoogwater en als dat water makkelijk kan infiltreren dan duurt de drainage van dit water vaak langer waardoor de grondwaterstand hoger is dan gemiddeld. Dit is een bekend fenomeen dat van belang is vooral bij zandplaten die dagelijkse onderlopen. Dit proces geldt overigens alleen voor de overspoelde platen. Als die er niet zijn (bv. een dijkje tussen land en water, een natuurlijke oeverwal, of een heel steile oever), dan is de verwachting dat de grondwaterlens dunner zal worden als gevolg van de wisselende waterstanden door getij. Dit komt omdat bij laagtij (groot potentiaalverschil) drainage sneller gaat dan de opbouw van de zoetwaterlens (tegen de zwaartekracht in) bij hoogtij. Daarnaast zal het freatisch vlak (grondwaterspiegel) lager komen te liggen als gevolg van de drainage. De gemiddelde grondwaterstand in een getijdesituatie zal dus iets dalen. Mogelijk dat het freatisch grondwaterniveau op de plekken die niet draineren evenveel omhoog zal gaan als een eventuele stijging van het middenpeil op termijn bij zeespiegelstijging. Daardoor zal vernatting optreden en het freatisch vlak op de laaggelegen delen het maaiveld bereiken. Deze vernatting wordt versterkt door de bodemvorming die op sommige delen al plaatsvindt (bv. de Hompelvoet) waardoor het water langer vastgehouden wordt. Zowel de sterkere drainage als langdurige vernatting is ongunstig voor vochtige duinvalleivegetaties. Het eerste leidt tot verdroging en verzuring (door uitloging van basen), het tweede tot verzuring (door stagnatie van regenwater). Verzuring leidt tot verlies van de kalkrijke duinvalleibegroeiingen. Vooral op relatief vlakke platen als Veermansplaat en Stampersplaat zal dit grote gevolgen hebben, omdat hier de veranderende waterstand een groot oppervlakte beslaat. Dit is precies de locatie met de grootste populatie van de Europees beschermde groenknolorchis (de Kraker, 2016). Mogelijk dat er op de Hompelvoet minder grote gevolgen te verwachten zijn vanwege de relatief hogere ligging en daardoor betere drainage en toestroom van kalkrijk grondwater vanuit hoger gelegen delen.

Welk van de hierboven beschreven processen domineert hangt af van het oppervlak van het overspoelde deel, maar ook de infiltratiecapaciteit van het oppervlak speelt een rol, bv. door slib kan infiltratie worden bemoeilijkt. Er zijn verschillende redenaties die allemaal kloppen waarbij een lens kan krimpen of juist kan groeien. Samengevat zijn dit de volgende drie processen:

1) Overstroming met zout water zorgt voor een kleinere infiltratiezone met zoet regenwater en daarmee een kleinere zoetwaterbel waardoor de zoetwaterbel kan krimpen.

2) Een hogere freatische grondwaterstand (door het overspoelingsproces) leidt tot een (veel dikkere) zoetwaterlens. Theoretisch is dit 1 op 40, volgens de Badon-Ghyben Herzberg relatie: bij een $20 \mathrm{~cm}$ hogere freatische grondwaterstand kan de lens theoretisch 8 meter dikker worden. In werkelijkheid zal dit anders zijn maar dit proces treedt wel op, en is ook behoorlijk significant. Dit zal leiden tot groei van de zoetwaterbel.

3) Daar staat tegenover dat getijdeslag (zonder overspoeling) leidt tot een dunnere lens dan een gemiddeld peil waardoor de lens weer krimpt doordat drainage plaatsvindt. 
Concluderend: hoe deze drie processen uiteindelijk interacteren en invloed hebben op de zoetwaterlens en daarmee de vegetatie is lastig te voorspellen. Nadere (modelmatige) analyse is nodig om hier inzicht in te krijgen.

Gevolgen van getij voor vegetatie

Volgens experts (zie Bijlage G, expertsessie 7 november 2017) zal de introductie van getij ervoor zorgen dat delen van de brakke/zilte overgangsvegetaties en duinvalleibegroeiingen overspoelen en verzilten. Daarnaast zullen wisselingen in peil door getij of peilbeheer een effect hebben op het grondwater. Uit de vorige paragraaf blijkt dat in alle scenario's de zoetwaterbel zal veranderen, wat volgens de experts in de meeste gevallen ongunstig zal uitpakken voor de duinvalleivegetaties. Duinvalleivegetaties kunnen vrijwel nergens opschuiven (zie verderop), en ze zullen daar waar ze overspoelen met zout water grotendeels verdwijnen. Dit zal met name spelen bij de jonge, laaggelegen vegetaties van het vochtige duinvalleitype met soorten als groenknolorchis, parnassia, vleeskleurige orchis en armbloemige waterbies. Hier liggen twee aspecten aan ten grondslag:

1. De duinvalleibegroeiingen kunnen niet opschuiven in de zonering omdat fysieke beperking optreedt door de aanwezigheid van struweel, stuifruggen, (voormalig) schorranden of bedijking. Waar latere successiestadia aanwezig zijn (ruigte, struweel, bos) zullen duinvalleibegroeiingen zich ook moeilijk vestigen na verwijderen van de aanwezige vegetatie, omdat de bodem hier te ver ontwikkeld is met een dikkere humuslaag (de duinvalleibegroeiingen staan op een kalkrijke, zandige, weinig ontwikkelde bodem);

2. Op locaties waar wel ruimte is en geen struweel/bos in de weg zit is er onzekerheid over de veranderingen in omvang en invloed van de zoetwaterbel. Grondwaterstanden liggen hier dieper onder het maaiveld waardoor het kalkrijke grondwater dat van belang is voor kalkrijke vochtige duinvalleivegetaties minder snel aan het maaiveld komt. Dit wordt bevestigd door de studie van Van de Haterd et al. (2010) waarin wordt aangegeven dat de bovengrens van deze vegetaties niet wordt bepaald door het zoutgehalte, maar door andere factoren (vocht, kalk en/of beheer).

Sommige delen van de Hompelvoet vormen mogelijk een uitzondering op omdat op dit relatief 'hoge' eiland kwelzones met kalkrijk grondwater kunnen opschuiven. Op plaatsen waar geen fysieke beperking is zouden duinvallei vegetaties mogelijk kunnen opschuiven.

De zilte graslanden zijn momenteel in een smalle zone aanwezig op plekken waar nog zout vanuit de bodem wordt nageleverd of waar incidentele overspoeling (opwaaiing) of zoutspray een rol speelt (RoyalHaskoning DHV 2017). Ze kunnen maar op een beperkt aantal plekken opschuiven naar hoger gelegen delen om de volgende redenen:

1. hogerop is er op veel plekken minder ruimte om op te schuiven door aanwezigheid van een stuifrand met struweel.

2. aanwezigheid van struweel/ruigte of zoetwaterbel belemmert opschuiving.

3. doordat het getij wordt begrensd aan de bovenzijde (waterinlaat stopt zodra het HW-niveau is bereikt) zullen onregelmatige, hogere waterstanden minder vaak voorkomen dan wanneer hogere standen worden getolereerd. Juist deze zijn relevant voor de zilte graslanden. Dit is dus afhankelijk van het peilbeheer van het doorlaatmiddel.

4. op een enkele locatie (Markenje) zijn geen hoger gelegen delen, het gehele eiland is al begroeid met zilte vegetatie.

De zilte graslanden zullen deels kunnen opschuiven in scenario's met getij, waardoor het verlies beperkt blijft, maar hier zitten wel beperkingen aan. Ook in de huidige situatie (bij autonome ontwikkeling) verliezen ze geleidelijk meer terrein door uitbreiding van de zoetwaterbel en ontzilting van de bodem. Mogelijk kunnen zilte graslanden op langere termijn zelfs duurzamer behouden blijven bij enig getij. Bij relatief groot getijverschil (RSV, RSV-zeespiegelstijging, RSV-peilbeheer) zullen ze echter sterker achteruitgaan, doordat een groter deel van het potentiële gebied voor uitbreiding in kaal slik of zilte pionierbegroeiing verandert. Er vindt niet genoeg sedimentatie plaats op de platen om hoger te groeien, opschuiving kan slechts in beperkte mate optreden (zie de eerdergenoemde punten), er ontstaan mogelijk erosiekliffen op de grens van zilt grasland en kaal slik. 
Effecten Natura 2000-habitats in een getijdensituatie

Hier wordt de invloed van getij op de habitattypen $\mathrm{H} 1310$ zilte pionierbegroeiingen (subtype A) en H2190 vochtige duinvalleien (subtype $B$ ) bediscussieerd. Eerder is in paragraaf 5.3 een inschatting gemaakt van de mate van overspoeling van de habitattypes H1310A en H2190 (Tabel9a/b). Tabel 11 geeft de ingeschatte achteruitgang van de twee habitattypes gebaseerd op direct verlies maar ook door indirect verlies als gevolg van veranderende omstandigheden zoals zoutspray, grondwaterstanden en incidentele overspoeling. Deze inschatting is gemaakt door experts. Hieronder volgt een beschrijving per habitattype.

\section{H1310 zilte pionierbegroeiingen}

De oppervlaktes zilte pionierbegroeiingen met zeekraal (subtype A) kunnen jaarlijks sterk verschillen, onder invloed van wind (wegspoelen van zaden) en neerslag (kieming in het voorjaar). Op dit moment zijn de oppervlaktes relatief groot dankzij het peilbeheer, dat zomers lagere waterstanden aanhoudt (blijkt uit veldwaarnemingen en expert-kennis). De zilte pioniers met zeekraal kunnen groeien tussen $10 \mathrm{~cm}$ onder en ongeveer $20 \mathrm{~cm}$ boven GHW ( +5 tot $+35 \mathrm{~cm}$ NAP) (Van de Haterd, 2010).

Zilte pioniervegetaties met zeekraal kunnen in de zonering opschuiven, waarbij echter twee redenen zijn waardoor ze mogelijk in omvang kunnen afnemen:

1. Door het ontbreken van sediment in het systeem is er grote kans dat op de grens van meer dichte vegetatie en kaal slik erosieklifjes ontstaan, waarmee het oppervlakte geschikt leefgebied afneemt;

2. Hoger in de zonering zijn in eerste instantie weinig onbegroeide delen aanwezig; op de reeds begroeide delen zal naar verwachting in eerste instantie een zilte, nitrofiele begroeiing ontstaan (met plantensoorten van aanspoelzones, bv. spiesmelde). Pas op iets langere termijn, bij afsterving van het aanwezig plantenmateriaal en het meer kaal worden van de bodem, kunnen zilte pioniersoorten (zeekraal, schorrenkruid) zich hier vestigen.

Peilbeheer kan wel een gunstige invloed hebben op het areaal omdat het dan in de zomer maanden kan uitbreiden. De inschatting is dat op termijn 30-50\% van $\mathrm{H} 1310 \mathrm{~A}$ verloren zal gaan in de RSV scenario en RSV springtij scenario (Tabel 11). Naar schatting is het verlies in het RSV-peilbeheer en Getij30 scenario beperkter (respectievelijk $10-30 \%$ en $20-40 \%$ ) en groter in het RSV-zeespiegelstijging scenario met een verlies van $60-80 \%$.

In de Aanvulling op de Natuureffectenstudie (RoyalHaskoning DHV 2017) wordt ingeschat dat dit habitattype zal profiteren van het getij. In natuurlijke situaties zal dit naar verwachting ook het geval zijn, maar de inschatting is dat juist op de grens van dichte vegetatie en kaal slik zoals genoemd erosiekliffen gaan optreden (er is onvoldoende sediment in het getijdesysteem) waardoor dit kan tegenvallen. Bovendien is de inschatting dat de huidige, relatief grote oppervlakte van het type door het manipuleren van het middelpeil in de huidige situatie een grotere rol speelt bij de veranderingen in areaal in de verschillende scenario's. Vandaar dat de ingeschatte verliezen geringer zijn in het scenario met peilbeheer in Tabel 11. In de Aanvulling op de Natuureffectstudie is verder berekend dat het habitattype $\mathrm{H} 1310$ nauwelijks een relatie heeft met het gehanteerde lagere zomerpeil (RoyalHaskoning DHV 2017, pg 77-78). Het gaat in die berekeningen deels om subtype $B$, dat hoog in de zonering voorkomt (boven habitattype 1330A), en inmiddels sterk in areaal is achteruitgegaan. Verder zijn de getoonde relaties voor subtype $A$ (dat hier van belang is) gebaseerd op metingen bij Bommenede, terwijl de grootste oppervlakte van dit subtype voorkomt op de platen van de Slikken van Flakkee Noord, aan de oostkant van het meer, waar de waterstanden sterker beïnvloed worden door opwaaiing (Foto 1). Ook is van belang om te benadrukken dat het oppervlakte van dit subtype A tussen jaren sterk kan fluctueren.

Het oppervlak van zilte pionierbegroeïngen met zeevetmuur (subtype B) is zoals eerder genoemd de afgelopen 15 jaar voor meer dan 90\% overgegaan in andere habitattypen, met name H2190B vochtige duinvalleien. De huidige oppervlakte is gering en zal naar verwachting bij getij kunnen blijven bestaan, aangezien het type kan opschuiven in de gradiënt tot in de zone van het jaarlijks hoogste getijbereik en zout-spray-bereik (zie ook Van de Haterd et al. 2010). 


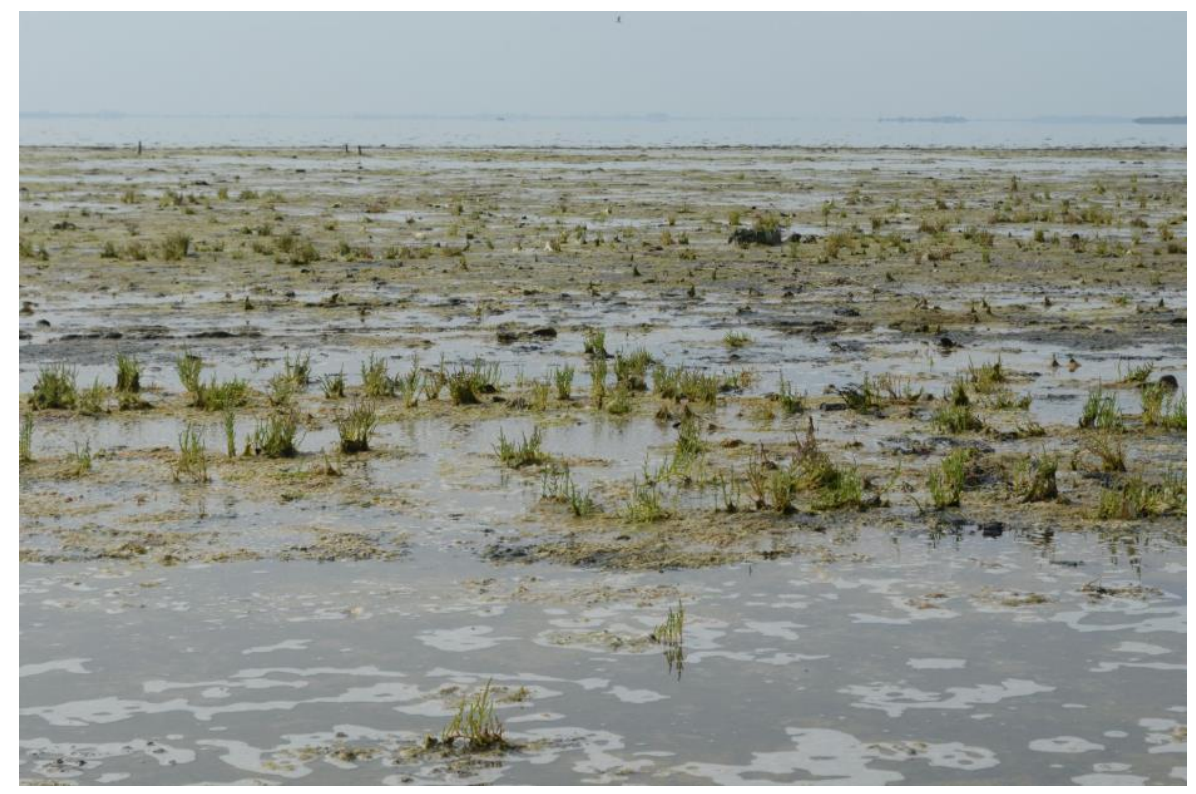

Foto 1: IJle pionierbegroeiingen met zeekraal nemen op de Slikken van Flakkee een flinke oppervlakte in op delen die 's winters onder water staan en in de zomer droog komen te staan door het gehanteerde peilbeheer.

\section{H2190 vochtige duinvalleien - kalkrijk}

Het verlies aan vochtige, kalkrijke duinvalleivegetaties (H2190B) is volgens de modelanalyse circa 11$14 \%$ bij $50 \mathrm{~cm}$ getijslag, afhankelijk van welke habitatbegrenzing (i.e. habitatkaart) wordt gebruikt (Tabel 9a/b). Dit verlies kan echter verder oplopen, omdat er door de veranderingen ook indirect geschikt milieu verloren gaat, door een veranderde zoetwaterbel (zowel vernatting door uitbreiding als drainage door inkrimpen zijn ongunstig, zie boven), een opschuivende zoutspray-zone en incidentele overstroming tijdens stormen. Deze indirecte effecten spelen een rol omdat dit type nauwelijks mogelijkheden heeft om op te schuiven door de aanwezigheid van hoger opgaande vegetatie (struweel, bos, ruigte) met de daarbij behorende verder ontwikkelde bodem, of door fysieke barrières (o.a. in de vorm van de kleiige, voormalige schorren). De verwachting is dat meer dan de in Tabel 9a/b genoemde oppervlakte van kalkrijke, vochtige duinvalleien (H2190B) zal verdwijnen, omdat ook de niet direct overspoelde oppervlakte van het type te maken zal krijgen met zoutspray en incidentele overstroming bij stormen, en een veranderde zoetwaterbel. Naar schatting zal in het Getij30 scenario 10-30\% verdwijnen en in de RSV scenario's minimaal $40-60 \%$ (Tabel 11). Dit areaal is groter dan eerdere schattingen in de aanvullende natuureffecten studie (RoyalHaskoningDHV, 2017) (naar schatting 30\% afname bij $50 \mathrm{~cm}$ getij en een vast peil) omdat het areaal $\mathrm{H} 2190$ in de randgebieden afgelopen jaren is toegenomen. In voorliggende studie wordt een hoger verlies ingeschat bij alle scenario's, omdat laag in de zonering (waar de hoogste directe en indirecte verliezen optreden) inmiddels brakke en zilte graslanden op de door RoyalHaskoning DHV (2017) en Van de Haterd et al. (2010) gebruikte vegetatiekaarten uit 2001/2005 door successie tot duinvalleibegroeiingen zijn ontwikkeld (gebaseerd op informatie van gebiedsdeskundigen/experts en ook de Kraker, 2017). Oftewel, de geschatte oppervlakte van habitattype 2190B is momenteel groter dan uit de gegevens van ruim 10-15 jaar geleden blijkt, en met name in de lage zones waar de grootste verliezen zullen optreden. Dat de grootste effecten in de laagste zone optreden is de reden dat wordt ingeschat dat een iets minder groot getijverschil $(30 \mathrm{~cm})$ een minder negatieve impact heeft, dan een groter getijverschil (zie Tabel 11).

De laagste zone van deze duinvallei-begroeiingen, waarin de groenknolorchis optimaal voorkomt (de Kraker, 2017), zal het sterkst achteruitgaan bij invoer van getij. Deze zone zal in dat geval grotendeels overstromen en bovendien is de zoetwaterbel hier relatief dun, waardoor sterke indirecte veranderingen optreden. De achteruitgang van groenknolorchis wordt daarom relatief groter ingeschat in elk scenario dan het verlies aan duinvallei-begroeiingen. Omdat de hoogste concentraties van deze orchidee in de laagste zones liggen (zie Figuur 10) wordt ingeschat dat de verliezen op populatieniveau hoger zijn dan de maximaal 30-70\% die in de Aanvulling op de Natuureffectenstudie (RoyalHaskoning DHV 2017) wordt gehanteerd. 
Tabel 11. Ingeschatte \% achteruitgang van de onder Natura 2000 beschermde habitats H1310A (Zilte pionierbegroeiingen -zeekraal) en H2190B (Vochtige duinvalleien - kalkrijk) en plantensoort Groenknolorchis bij de verschillende scenario's. De expert inschatting is gebaseerd op een combinatie van direct verlies (Tabel 9), indirect verlies (door veranderde zoetwaterbel, zoutspray en incidentele overstroming bij storm) en mogelijkheden om op te schuiven. Hierbij is tevens afgewogen dat habitattype $2190 \mathrm{~B}$ (inmiddels) meer voorkomt dan op de gebruikte habitatkaart is aangegeven.

\begin{tabular}{|l|l|l|l|}
\hline Scenario & H1310A & H2190B & Groenknolorchis \\
\hline 0. Huidige situatie & $\begin{array}{l}\text { stabiel, ook op } \\
\text { termijn }\end{array}$ & $\begin{array}{l}\text { langdurig te } \\
\text { behouden bij huidig } \\
\text { intensief beheer; } \\
\text { op termijn van } \\
\text { decennia wel } \\
\text { geleidelijk } \\
\text { achteruitgang door } \\
\text { oppervlakkige } \\
\text { verzuring en } \\
\text { bodemvorming }\end{array}$ & $\begin{array}{l}\text { langdurig te } \\
\text { behouden bij huidig } \\
\text { intensief beheer; } \\
\text { op termijn van } \\
\text { decennia wel } \\
\text { geleidelijk } \\
\text { achteruitgang }\end{array}$ \\
\hline 1. RSV & & $-40 / 60 \%$ & $-70 / 90 \%$ \\
\hline 2. RSV-springtij & $-30 / 50 \%$ & $-40 / 60 \%$ & $-90 \%$ \\
\hline 3. Getij30 & $-30 / 50 \%$ & $-10 / 30 \%$ & $-20 / 40 \%$ \\
\hline 4. RSV-peilbeheer & $-20 / 40 \%$ & $-70 \%$ & $-99 \%$ \\
\hline $\begin{array}{l}\text { 5. RSV- } \\
\text { zeespiegelstijging }\end{array}$ & $-10 / 30 \%$ & $-90 \%$ & $-99 \%$ \\
\hline
\end{tabular}

\section{Mogelijke mitigatiemaatregelen}

Zoals eerder aangegeven zullen vochtige duinvallei vegetaties op de meeste plaatsen niet of nauwelijks opschuiven vanwege fysieke barrières zoals aanwezigheid van struweel of bos en meer voedselrijke bodem op de hogere delen of het ontbreken van terrein met een geschikte bodemhoogte. Een mogelijkheid is om het struweel te verwijderen en de bodem af te plaggen tot net boven de nieuwe grondwaterstand. Hiermee worden omstandigheden gecreëerd die in principe gunstig zijn voor vochtige duinvallei vegetaties om te ontwikkelen. Hierbij worden de volgende kanttekeningen geplaatst:

- Het gaat op de oevers/eilanden van de Grevelingen om vele tientallen tot honderden hectares; dus dit vraagt een flinke inspanning (zoals soms ook in de duinen wordt gedaan).

- Op plaatsen waar struweel of bos aanwezig is zal diep geplagd moeten worden om alle wortels te verwijderen. Daarnaast komt het maaiveld door het afplaggen ook weer lager te liggen en daarmee mogelijk ook binnen de invloed van het zoute water (in lage zones) of treedt stagnatie van water op (vernatting) op hogere delen. Succes van mitigatie is daarmee niet zomaar gegarandeerd.

- Dergelijke maatregelen gaan ten koste van andere habitattypen die deels beschermd zijn onder Natura 2000 (duindoorn- en kruipwilgstruwelen) en deels niet (bossen).

- Omdat op deze manier duinvalleien niet ontstaan vanuit een geleidelijk verzoetend milieu op zandige bodem, waarbij een dunne zoetwaterlens aanwezig is, zijn dergelijke gemitigeerde duinvalleien waarschijnlijk minder geschikt voor de groenknolorchis.

\section{Broedvogels}

Effecten getij op broedvogels

Huidige broedgebieden voor kustbroedvogels bevinden zich juist op de laaggelegen delen van o.a. Slikken van Bommenede, Markenje en de Slikken van Flakkee. Bij het invoeren van gedempt getij, zonder peilbeheer, zullen deze gebieden overspoelen en verloren gaan. M.a.w., het ecotoop zomer droog, dat in de huidige situatie voorkomt dankzij het peilbeheer, zal in alle scenario's met gedempt getij zonder peilbeheer verloren gaan. Hoe hoger het water komt hoe meer verlies van broedbiotoop. Op een robuuste kale zone met aangrenzend grasland van $>500$ meter kunnen kustbroedvogels en weidevogels terecht. Bij gedempt getij, zonder peilbeheer, zal er maar een zeer beperkt deel van deze zone overblijven. De verwachting is tevens dat broedvogels nabij de struweel/bosrand minder snel tot broeden zullen komen door de aanwezigheid van otentiële predatoren zoals haviken en kraaien (Slikken van Bommenede, Slikken van Flakkee-Noord). De Strandplevier, waarvoor het Grevelingenmeer van bijzondere betekenis is als broedgebied, is bijzonder kwetsbaar voor deze afname van areaal, omdat deze soort solitair broedt en weidse kale of schaars begroeide zones prefereert. De verwachting is dan ook dat het aantal broedparen fors zal afnemen. Het voeren van peilbeheer met een lager peil in de zomer dan in de winter, zoals in scenario 4 'RSV-Peilbeheer', is wel gunstig voor het ontstaan van 
schaars en onbegroeide terreinen om te broeden, vergelijkbaar met het zomer droog ecotoop in de huidige situatie.

\section{Mogelijke beheers- en mitigatiemaatregelen}

Met gerichte inspanningen kan men kansen creëren voor broedvogels. Introductie van getij zou geen probleem moeten zijn als voorzien wordt in mitigerende maatregelen voor broedvogels. Dit gaat echter niet voor alle soorten op. Voor Visdieven kunnen drijvende voorzieningen met schelpengruis worden gecreëerd. Voor soorten als de Grote stern en de Strandplevier wordt het lastiger omdat deze soorten gebaat zijn bij robuuste broedgebieden. Eilanden zoals Markenje en de Kleine Stampersplaat kunnen opgehoogd worden om boven het getij uit te komen en behoud van broedgebied te waarborgen. Dit gaat echter wel om aanzienlijke oppervlakten (tientallen hectaren). Deze gebieden zullen beheerd moeten worden om successie tegen te gaan, of ze moeten in het winterseizoen enkele malen kunnen overstromen met zout water. Eén geschikt broedgebied is niet genoeg. Soorten zoals de Grote stern zijn opportunistisch en bekijken per jaar waar ze willen broeden. Bijvoorbeeld als er predatoren aanwezig zijn op Markenje kunnen ze uitwijken naar een andere locatie. Op sommige plekken zullen broedvogels wellicht niet terugkeren omdat het gebied niet meer robuust genoeg is zoals voor Strandplevieren die brede, kale slikken prefereren. Aanleg van broedgebieden, zoals bijvoorbeeld opspuiten van broedeilanden, biedt vooral kansen voor koloniebroedende vogels zoals sternsoorten en meeuwen. Aanleg van een (broedvogel)eiland in de Voordelta is ook een mogelijkheid of de ontwikkeling van binnendijkse broedgebieden (zoals bv. Utopia op Texel). Dit soort broedgebieden zijn gunstig voor het hele Deltagebied. Benadrukt wordt dat een combinatie van meerdere maatregelen nodig is om de negatieve effecten op broedvogels te kunnen mitigeren. Ook dan zal dit niet alle soorten kunnen bedienen.

\section{Zoogdieren: de noordse woelmuis}

De belangrijkste gebieden voor de noordse woelmuis in de Grevelingen zijn: Slik de Kil (Punt van Goeree), Markenje en de Slikken van Flakkee-Noord: allemaal niet-begraasde gebieden. Bij invoering van getij neemt op deze locaties het geschikte areaal af doordat een deel van het huidige leefgebied onder invloed van het getij komt en de zone met brakke ruigte niet kan opschuiven zoals bij Markenje en bij de overige twee gebieden alleen wanneer een brede strook van het aanwezige struweel verwijderd wordt (de Kraker, 2017). Bovendien is het onzeker of zich op deze strook geschikt habitat zal ontwikkelen. De verwachting is dat het leefgebied van de noordse woelmuis af zal nemen omdat deze soort vooral voorkomt op de laaggelegen delen met grasruigte die door het getij veranderen in intergetijdengebied. Gebieden die geregeld overstromen (bijvoorbeeld bij springvloed) zijn ongeschikt, evenals zilte vegetaties.

\subsection{Relatie met omliggende gebieden}

Intergetijdengebieden zijn belangrijke foerageergebieden voor vogels. In de omliggende gebieden (Oosterschelde en Westerschelde) staan de intergetijdengebieden onder druk. Sinds de aanleg van de Oosterscheldewerken stroomt er minder water in en uit de Oosterschelde. De getijdengeulen zijn te groot voor de kleinere hoeveelheid water. Het water stroomt daardoor langzamer dan voorheen en heeft onvoldoende kracht om sediment te verplaatsen van de geulen naar het intergetijdengebied. Bij storm spoelt er wel zand van het intergetijdengebied in de geulen. Al het zand dat in de geulen terecht komt, blijft daar liggen. De afbrekende krachten werken nog wel, maar de opbouwende krachten niet. Hierdoor overheerst de afbraak van intergetijdengebied. Een proces dat bekend staat als de "zandhonger" (Van Zanten en Adriaanse, 2008). Doordat de intergetijdengebieden kleiner worden en korter droogvallen neemt het foerageergebied af en hebben vogels minder tijd om te foerageren. Steltlopers moeten lang genoeg kunnen foerageren tijdens laagwater om een hoogwater te kunnen overbruggen. De verwachting is dat het aantal vogelsoorten dat voedsel zoekt, door de afname van het foerageergebied drastisch afneemt. Door de verdieping van de Westerschelde neemt de getijdenslag toe in de Westerschelde. Door een toename in stroomsnelheden vindt versteiling en verhoging van de platen plaats (de Vet et al. 2017). Als de platen te hoog komen te liggen vindt vestiging van vegetatie plaats. Door de steilere hellingen, hogere ligging en successie neemt ook hier het foerageerareaal af. Intergetijdengebieden die in de Grevelingen ontstaan na invoering van gedempt getij kunnen een positieve bijdrage leveren aan het areaal voor bodemdieretende vogels. 


\section{Optimalisatie waterbeheer}

De voorkeursvariant van de Rijksstructuurvisie met $50 \mathrm{~cm}$ getij via een doorlaat in het noordelijk deel van de Brouwersdam (scenario 1) geeft nog enige ruimte voor optimalisatie m.b.t. de sturing van het doorlaatmiddel en daarmee de getijkromme, het al dan niet toelaten van springtij, mogelijke instelling van peilbeheer etc. In deze paragraaf worden optimalisatiemogelijkheden bediscussieerd.

\subsection{Mogelijkheden en beperkingen van het nieuwe doorlaatmiddel}

De waterstand in het Grevelingenmeer is gereguleerd. Dat is nu het geval (zie paragraaf 4.1) en dat zal met het nieuwe doorlaatmiddel in de Brouwersdam ook zo zijn. Zonder sturing zou de gemiddelde waterstand in het Grevelingenmeer hetzelfde zijn als in de Voordelta (circa 0,03 m NAP) en zou de getijvariatie het springtij-doodtij van de Voordelta volgen inclusief momenten van wind- en stormopzet. Om het middenpeil en de boven- en ondergrens te handhaven -al dan niet met seizoensgebonden variatie- zal dus gestuurd moeten worden. Voor die sturing zijn in theorie 17 "knoppen" beschikbaar bestaande uit a. de huidige Brouwerssluis, b. de Flakkeese spuisluis, en c. de 15 kokers van het referentieontwerp van het nieuwe doorlaatmiddel in de Brouwersdam. Het is overigens nog niet bekend of de 15 kokers individueel bediend kunnen gaan worden of bijvoorbeeld per 3 of 5 kokers. Sturing bestaat uit het vergroten of verkleinen van het doorstroomoppervlak van de 17 "knoppen", ofwel het (eventueel gedeeltelijk) open- of dichtzetten van de 17 "knoppen". Het resulterende debiet door de kunstwerken is vervolgens alleen afhankelijk van het waterstandsverschil tussen Grevelingenmeer en Voordelta en tussen Grevelingenmeer en Oosterschelde (Zijpe). Zie Bijlage E voor een beschrijving van het OD-model, waarin dit is toegepast.

Het referentieontwerp van het nieuwe doorlaatmiddel in de Brouwersdam is zo gedimensioneerd dat in combinatie met de Brouwerssluis en de Flakkeese spuisluis - bij doodtij een getijslag van $50 \mathrm{~cm}$ gerealiseerd kan worden. Bij doodtij is het waterstandsverschil het kleinst en is dus het grootste doorstroomoppervlak nodig om het benodigde debiet te realiseren. De ebfase in de Voordelta is daarin weer sturend, omdat door het lagere middenpeil van het Grevelingenmeer de tijdsduur dat de waterstand in de Voordelta lager is dan in het Grevelingenmeer (het afwatervenster) korter is dan de tijdsduur dat de waterstand in de Voordelta hoger is dan in het Grevelingenmeer. De tijdsverhouding is ordegrootte 45\%:55\%. Anders gezegd, bij eb in de Voordelta is er minder tijd om $50 \mathrm{~cm}$ water af te voeren, terwijl bij vloed in de Voordelta meer tijd is om diezelfde $50 \mathrm{~cm}$ weer aan te voeren.

Dit betekent dat het nieuwe doorlaatmiddel tijdens de vloedfase in de Voordelta en bij een groter waterstandsverschil zoals bij springtij feitelijk overgedimensioneerd is: niet het volledige doorstroomoppervlak is nodig en het nieuwe doorlaatmiddel zal (deels) gesloten moeten worden. De wijze waarop deze sluiting met de 15 kokers gerealiseerd wordt, is nog niet bekend en biedt veel mogelijkheden voor zogenaamde fijnafregeling van de getijkromme op het Grevelingenmeer. Samenvattend: Als er overcapaciteit is van het nieuwe doorlaatmiddel, biedt dat ruimte om de getijkromme op te leggen.

Figuur 19 illustreert de mogelijkheden voor fijnafregeling. De (geïdealiseerde) getijkromme bij doodtij laat zien dat $50 \mathrm{~cm}$ getij precies gerealiseerd wordt. Als er geen sturing is bij springtij, zal de waterstand in het Grevelingenmeer sneller stijgen bij vloed en dalen bij eb en zal het nieuwe doorlaatmiddel gedurende enkele uren gesloten moeten worden om de waterstand binnen de (hier gebruikte) grenzen van $+0,05$ en $-0,45$ m NAP te houden. De ruimte tussen de twee lijnen is beschikbaar voor fijnafregeling.

Bij gelijkblijvende peilvoorwaarden in het Grevelingenmeer zal zeespiegelstijging ervoor zorgen dat het afwatervenster steeds korter wordt. Daardoor is als eerste bij doodtij onvoldoende tijd om $50 \mathrm{~cm}$ water af te voeren. Bij grotere zeespiegelstijging op een gegeven moment ook bij springtij de capaciteit onvoldoende zijn. Bij een bij de huidige omstandigheden passend doorlaatmiddel zal naar verwachting na 30 centimeter zeespiegelstijging het middenpeil waarschijnlijk omhoog moeten. Er ontstaan drie opties om hiermee op te gaan: 
1. De getijslag in het Grevelingenmeer neemt af.

2. De capaciteit van het doorlaatmiddel wordt vergroot bijvoorbeeld door extra kokers, zodat hetzelfde peilbeheer gehandhaafd kan worden. Als al bij aanleg overcapaciteit (een of meer extra kokers) wordt aangelegd, kan een grotere zeespiegelstijging opgevangen worden.

3. Het peil in het Grevelingenmeer stijgt evenredig mee met de zeespiegelstijging, zodat de dezelfde capaciteit van het nieuwe doorlaatmiddel gehandhaafd blijft.

Een (seizoensgebonden) verlaging van het middenpeil heeft consequenties voor het peilbeheer. Bij doodtij zal het nieuwe doorlaatmiddel onvoldoende capaciteit hebben om $50 \mathrm{~cm}$ te realiseren, omdat het afwatervenster door de peilverlaging verkort is. Om de capaciteit ook tijdens een seizoensgebonden verlaging van bijv. $6 \mathrm{~cm}$ zoals in het huidige peilbeheer in alle gevallen te handhaven zou een extra $\left(16^{\mathrm{e}}\right)$ koker nodig zijn.

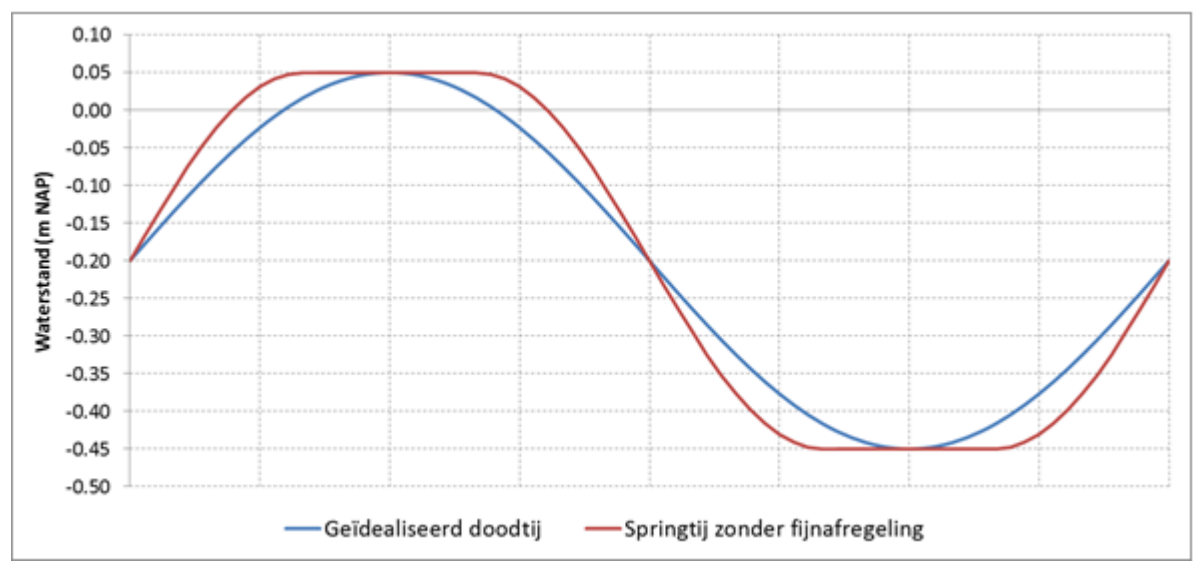

Figuur 19. Illustratie van de getijkromme voor doodtij in de Voordelta waarop het nieuwe doorlaatmiddel zodanig is gedimensioneerd dat precies $50 \mathrm{~cm}$ getijslag wordt bereikt (blauw) en voor springtij waarbij de capaciteit van het nieuwe doorlaatmiddel overgedimensioneerd is waardoor het enkele uren zal moeten sluiten.

In paragraaf 4.1 is beschreven dat windopzet van enkele tientallen $\mathrm{cm}$ bij harde storm mogelijk is. Als het onderlopen van normaal droge delen voorkomen zou moeten worden, kan het peilbeheer daarin voorzien door bij voorziene storm het waterpeil op een laag niveau van bijvoorbeeld $-0,45 \mathrm{~m}$ NAP te brengen. Er ontstaat dan een ruimte van in dit voorbeeld $50 \mathrm{~cm}$ op de windopzet op te vangen.

Tenslotte merken we op dat er een faseverschil is tussen het moment van vloed en eb in het Grevelingenmeer, in de Voordelta en de Oosterschelde (illustratie in Figuur 20). Hoogwater en laagwater in het Grevelingenmeer zijn ongeveer 4 uur later dan in de Voordelta en ongeveer 1,5 tot 2 uur later dan in de noordtak van de Oosterschelde (Zijpe). Dit houdt in dat intergetijdengebieden niet volledig gelijktijdig overstromen of droogvallen. Bijvoorbeeld bij hoogwater op de Voordelta is nog veel areaal intergetijdengebied in het Grevelingenmeer drooggevallen. Bij hoogwater in het Grevelingenmeer is in de Voordelta alweer een groot deel van het intergetijdengebied drooggevallen.

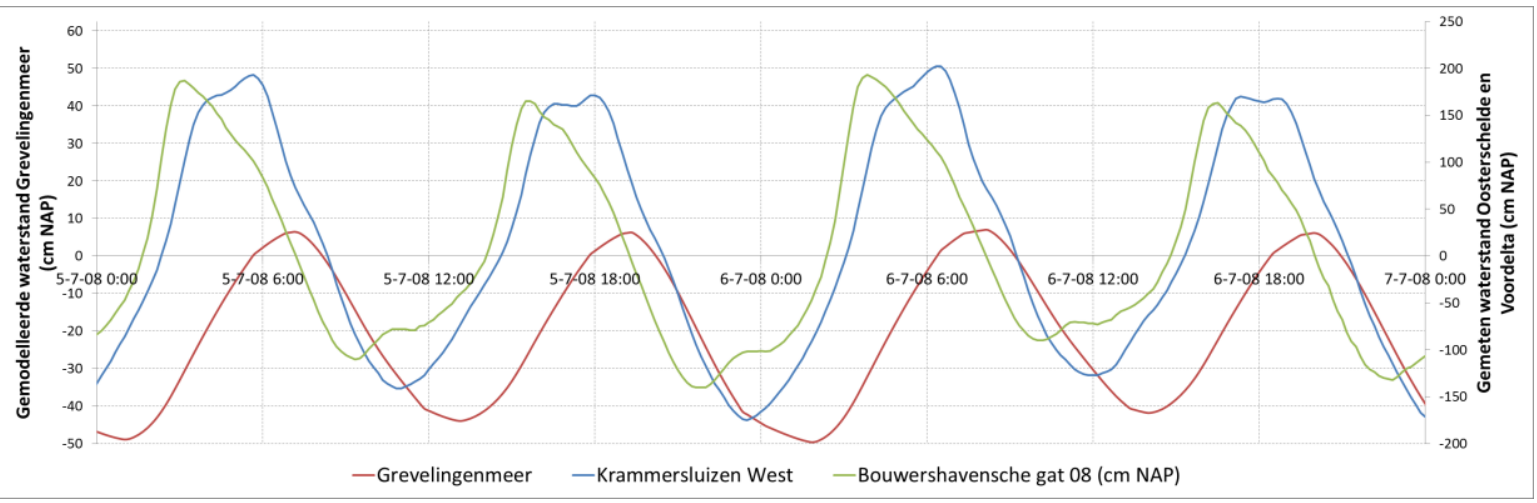

Figuur 20. Waterstandsverloop in het Grevelingenmeer (gemodelleerd) ten opzichte van waterstandsverloop in de Voordelta (gemeten locatie Brouwershavensche gat 08) en de Oosterschelde (gemeten locatie Krammers/uizen West) 


\subsection{Verkennen opties voor optimalisatie waterbeheer voor natuurwaarden}

In deze paragraaf worden de wensen en mogelijkheden besproken voor optimalisatie vanuit natuurwaarden in relatie tot het waterbeheer in een situatie met gedempt getij met het nieuwe doorlaatmiddel.

\section{Sturen van getij ten bate van foeragerende vogels}

Tijdens de expertsessie over natte natuurwaarden (zie Bijlage $\mathrm{G}$ ) is gesproken over de voordelen van een "a-synchroon getij" voor steltlopers. Dit houdt in dat gestuurd wordt op een faseverschil tussen het getij in het Grevelingenmeer en dat op de Noordzee en ook Oosterschelde en Westerschelde. Door een gestuurde vertraging van bijvoorbeeld een paar uur ontstaat een situatie waarbij het hoogwater is in de omliggende wateren terwijl het op het Grevelingenmeer laag water is. Dit biedt mogelijk grote voordelen voor overtijende steltlopers die van de Oosterschelde naar het Grevelingenmeer vliegen en zou betekenen dat ze toch kunnen blijven foerageren tijdens hoogwater in de omliggende wateren.

Gunstig voor foeragerende vogels is een geleidelijk afgaand getij zodat ze al foeragerend de waterlijn kunnen volgen (vloed dominant getij, snel op en langzaam af). In een klein laagje water zijn bodemdieren vaak nog actief en makkelijker te vangen door vogels. Zodra het slik droogvalt trekken bodemdieren zich vaak terug en zijn ze minder actief en daardoor minder snel detecteerbaar voor vogels. Een vraag is nog wat de haalbaarheid is van een vertraagde ebfase in relatie tot het "ebvenster" (de tijd dat het water naar de Noordzee kan lopen) met het nieuwe doorlaatmiddel. Doordat het middenpeil in het Grevelingenmeer lager ligt dan in de Voordelta, duurt het ebvenster korter dan het vloedvenster. Het is haalbaar om laagwater langer vast te houden omdat het resterende vloedvenster lang genoeg duurt. Het doorlaatmiddel is gedimensioneerd om bij doodtij $50 \mathrm{~cm}$ water af te kunnen laten. Dan is een gestuurde vertraging van de ebfase niet mogelijk. Bij een groter getij is wel enige sturing mogelijk om eb trager te laten verlopen.

\section{Peilbeheer ten bate van broedvogels en vegetatie}

Kustbroedvogels (kalegrondbroeders) hebben baat bij van oorsprong natuurlijke fluctuaties in waterstanden met meer stormen in de winter (opzet) en relatief rustige perioden in de zomer waarbij de kale delen als broedgebied fungeren. De winterperiode zorgt ervoor dat de gebieden (regelmatig) overstromen waardoor vegetatieontwikkeling onderdrukt wordt. Te dichte en hoge vegetatie is niet wenselijk voor deze kalegrondbroeders (Kluut, Bontbekplevier, Strandplevier, sternen, etc.). Een optimalisatiekans is het nabootsen van een peilbeheer dat deze kale zones langs de oevers in stand houdt en daarmee voldoende groot areaal aan geschikt broedbiotoop oplevert. Een voorbeeld van voor broedvogels geschikt peilbeheer:

- Winterpeil: Eind augustus-maart vast op -0,20m NAP met schommelingen tussen $-0,25$ en 0 meter NAP

- Zomerpeil: April-eind augustus vast op -0,25 m NAP met schommelingen tussen -0,25 en -0,30 m NAP

- Incidenteel: tweemaal per jaar tot $+0,06 \mathrm{~m}$ NAP begin september (niet eerder vanwege broedende sterns) en begin maart. Een peilopzet in de late zomer is gunstig omdat grondwaterstanden dan relatief laag staan en zout water makkelijker kan infiltreren en effectiever vegetatiesuccessie kan terugzetten.

Peilbeheer zoals hierboven omschreven kan ook toegepast worden in een situatie met getij. Peilbeheer is gunstig voor de ontwikkeling van zoute pioniervegetatie op de hoogste delen van de zandplaten. In het winterseizoen is het niet bezwaarlijk om extra opzet bij storm toe te laten, hoewel zoutinvloed in principe altijd ongunstig is voor de duinvalleivegetaties. Dat betekent wel dat het beheer van het doorlaatmiddel de ruimte moet kunnen bieden om incidenteel waterstanden boven GHW toe te staan. In scenario 4 'RSV-Peilbeheer' wordt uitgegaan van een zomerpeil van -0,26m NAP en een winterpeil van $+0,10 \mathrm{~m}$ NAP. De peilfluctuatie in dit scenario is zo groot dat het mogelijk ten koste zal gaan van vochtige duinvalleivegetaties (te lage waterstanden in de oevers). Een minder grote fluctuatie zoals hierboven beschreven is toereikend om de genoemde voordelen voor broedvogels en zoute vegetaties te creëren. 


\section{Conclusies, discussie, aanbevelingen en kennisvragen}

Het eerste doel van deze studie was het kwantitatief beschrijven van de potentiële verschuiving van ecotopen in verschillende scenario's van waterbeheer met gedempt getij in het Grevelingenmeer, incl. de autonome ontwikkeling bij voortzetting van het huidige beheer. In het algemeen kan geconcludeerd worden dat de invoering van gedempt getij zal zorgen voor het ontstaan van intergetijdengebieden in het Grevelingenmeer die deels ten koste gaan van het ondiep water ecotoop en deels de terrestrische ecotopen.

Het tweede doel van deze studie was het kwalitatief beschrijven van de potentiële ontwikkeling van natuurwaarden met behulp van expert oordeel. De kwalitatieve ontwikkeling voor de scenario's is ingeschat met behulp van expertoordeel met focus op de in deze studie gedefinieerde speerpunten (zie paragraaf 1.3 en 2.1). Hierbij zijn ook de effecten op Natura 2000 habitattypes ingeschat (H1310A en H2190B).

Het derde doel van de studie was mogelijke kansen aan te geven voor optimalisatie van waterbeheer ten bate van specifieke (of gewenste) natuurwaarden.

Hieronder worden de conclusies ten aanzien van de doelen geformuleerd, beperkingen en onzekerheden van het onderzoek bediscussieerd, en aanbevelingen gedaan voor toekomstig onderzoek en leemtes in kennis aangegeven.

\subsection{Ontwikkeling Grevelingenmeer na afsluiting en verwachte autonome ontwikkeling}

\section{Systeem in ontwikkeling}

Het is van belang om te benadrukken dat het Grevelingenmeer in de huidige situatie, 45 jaar later, nog steeds in ontwikkeling is als gevolg van de afsluiting. Het Grevelingenmeer is een dynamisch systeem dat na de afsluiting veel fluctuaties en verschuivingen heeft laten zien, zowel in het open water als op de drooggevallen slikken en oude schorren, de huidige eilanden en oevers. Dit kwam naar voren tijdens de expertsessies. Tot aan de opening van de Brouwerssluis in 1978 is het meer eerst verzoet wat zijn weerslag had op het ecosysteem. In de periode daarna ontwikkelde het tot een zeer helder zoutwater meer, uniek in het Deltagebied. Het meer vormt een relatief jong ecosysteem met grote verschuivingen in vis- en vogelstand, soortenrijkdom en dichtheden van onder meer macrobenthos, opkomst en ondergang van zeegras, en is nog steeds in verandering.

\section{Waardevolle terrestrische natuurwaarden}

Tijdens de expertsessie kwam naar voren dat de ontstane, waardevolle natuurwaarden op de oevers en eilanden zich reeds lange tijd handhaven, onder meer dankzij gerichte beheersmaatregelen. Zo is na bijna 50 jaar het Grevelingenmeer nog steeds van groot belang voor verschillende soorten kustbroedvogels en bij een goed beheer kan het dat nog lang blijven. Dit is een groot verschil met bijvoorbeeld het Veerse Meer waar door een ander beheer (hoog zomerpeil en laag wintepeil) vegetatiesuccessie heeft kunnen plaatsvinden en op de eilanden kale delen om te broeden tegenwoordig zo goed als afwezig zijn. Ook het voorkomen van vochtige duinvalleivegetaties langs de oevers en op de eilanden van het Grevelingenmeer laat zien dat de successie traag verloopt, mede dankzij het intensieve beheer en de van oorsprong zandige, relatief voedselarme platen. De groenknolorchis (pionierstadium) komt momenteel in groten getale voor in de laagste zones van de duinvalleien, voornamelijk op de Veermansplaat. De successie is dus, bijna 50 jaar na afsluiting, pas in een stadium waarbij - vanuit een brakkere situatie - een optimum aan jonge, vochtige duinvalleivegetaties optreedt. Deze vegetaties veranderen maar zeer geleidelijk en kunnen bij continuering van het huidige (intensieve) beheer en ononderbroken aanvoer van kalkrijk grondwater nog meerdere decennia voortbestaan. Uiteindelijk zullen ze als gevolg van successie veranderen van samenstelling. Wat ervoor in de plaats komt is onzeker, maar de kans op waardevolle, (hei)schrale graslanden is groot. De zilte vegetaties zullen in de toekomst met voortzetting van het huidige beheer nog verder afnemen als gevolg van het geleidelijk verzoeten van de oever (uitspoelen van de bodem) en als gevolg van erosie. 


\section{Waterkwaliteit}

De gemodelleerde zuurstofcondities in de verschillende scenario's geven een beeld van het areaal zuurstofloos oppervlak dat kan optreden. De werkelijke situatie is vooral afhankelijk van de meteorologische condities en verschilt daardoor van jaar tot jaar. Een warme, windstille zomer is ongunstiger dan een koele zomer met een aantal periodes van harde wind die voor menging van het water zorgen.

Enkele mechanismen zijn niet in het beschikbare model meegenomen zoals het afsterven van algen zoals Zeesla die vervolgens kunnen ophopen in sommige delen van het meer, zoals nabij de Grevelingendam (ondiep deel) en het noordelijk deel van de Brouwersdam, en lokaal voor een extra zuurstofvraag op de bodem zorgen. Veldwaarnemingen door Bureau Waardenburg tonen aan dat bacteriematten en schade aan het bodemleven ook in de ondiepe zones kunnen voorkomen vanaf een waterdiepte van 5 meter en de zuurstofloosheid mogelijk dus grootschaliger is dan uit de modelanalyses naar voren komt.

Het Grevelingenmeer als voormalig estuarium vormt nu een stagnant, zout meer met beperkte uitwisseling met de Noordzee (Brouwerssluis) en de Oosterschelde (Flakkeese spuisluis). Na afsluiting kwam het optreden van zuurstofloosheid op de bodem van het meer aan het licht. Het is van belang om te benoemen dat het optreden van zuurstofloze condities in stagnante, zwak-dynamische, diepe meren een natuurlijk fenomeen is. Zo treden er van nature zuurstofloze condities op in diepe zoetwatermeren en delen van stagnante zoute systemen zoals in de Oostzee en de diepe fjorden in Noorwegen en Denemarken. De kunstmatige toestand van het Grevelingenmeer laat zich niet één-op-één vergelijken (afgedamd estuarium met diepe geulen) met deze systemen. Daardoor ontbreekt er een goede referentiesituatie voor het Grevelingenmeer als een stagnant zout meer.

\subsection{Introductie gedempt getij in relatie tot natuurwaarden}

Verschuiving van ecotopen en Natura 2000-habitattypen bij gedempt getij (op basis van de modellen) De belangrijkste conclusies ten aanzien van de ecotopen voor de in deze studie onderzochte scenario's zijn als volgt:

- Huidige situatie (scenario 0): als gevolg van het huidige peilbeheer (zomerpeil $6 \mathrm{~cm}$ lager dan winterpeil) ontstaat in de zomermaanden een droogvallende zone, het ecotoop "Zomer droog", dat geschat wordt op enkele honderden ha. Deze droogvallende zone draagt bij aan geschikt broedgebied voor (grondbroedende) kustbroedvogels.

- Scenario 1 'RSV' (50 cm getij) en scenario 3 'Getij30' (30 cm getij): Het scenario met $50 \mathrm{~cm}$ getij leidt tot een groter areaal potentieel intergetijdengebied (zo'n 1100 ha) dan dat met 30 cm getij (zo'n 800 ha). Dit nieuwe intergetijdengebied komt deels in de plaats van ondiep water ecotoop en het zomer droog ecotoop, omdat in scenario RSV en Getij30 geen variabel peilbeheer is opgenomen. In beide scenario's zal het ecotoop terrestrisch met zoutinvloed volgens het model opschuiven naar boven en in areaal iets toenemen t.o.v. de Huidige situatie, terwijl vooral terrestrisch zoet verloren gaat (zo'n 400 ha in RSV en zo'n 300 ha In Getij30 scenario).'

- Scenario 2 'RSV Springtij' (50 cm getij $+/-5 \mathrm{~cm}$ springtij/doodtij): dit scenario is vergelijkbaar met scenario RSV; in dit scenario ontstaat zo'n 1100 ha intergetijdengebied en aanvullend een relatief geringe schorzone geschat op ongeveer 30 ha.

- Scenario 4 'RVS-Peilbeheer' (50 cm getij + $36 \mathrm{~cm}$ verschil tussen zomer- en winterpeil): in dit scenario ontstaat het grootste areaal intergetijdengebied met zo'n 1700 ha, maar hiervan is slechts een gering oppervlak permanent intergetijdengebied (150 ha), het grootste deel wordt gevormd door het zomer intergetijdengebied (zo'n 950 ha) dat in de winter onder water staat. In dit scenario gaat een groter deel van de terrestrische ecotopen verloren (zo'n 850 ha) dan in de RSV, Getij30 en RSV-Springtij scenario's. Het areaal ondiep water gaat achteruit met zo'n 500 ha.

- Scenario 5 'RVS-Zeespiegelstijging' (50 cm getij en $40 \mathrm{~cm}$ peilophoging): In dit scenario zal 700 ha intergetijdengebied overblijven, gevoelig minder dan in het RSV scenario. Zowel het 'ondiep water' als het 'diep water' ecotoop neemt toe (elk zo'n 100 ha). In dit scenario treedt het grootste verlies aan terrestrische ecotopen op met 40\% (zo'n 850 ha). Dit duidt het belang aan om met zeespiegelstijging rekening te houden. 
De belangrijkste conclusies ten aanzien van de Natura 2000-habitattypen voor de in deze studie onderzochte scenario's zijn als volgt (op basis van twee verschillende habitatkaarten):

- Het habitattype 'Zilte pionier begroeiingen met zeekraal' (H1310A) valt in alle scenario's met $50 \mathrm{~cm}$ getij voor $>90 \%$ of meer binnen de getijdeninvloed en zullen in de scenario's 4 'RSVPeilbeheer' en 5 'RSV Zeespiegelstijging' vrijwel geheel overspoelen. Bij scenario 3 met $30 \mathrm{~cm}$ getij is dit $>80 \%$.

- $\quad$ Het habitattype 'Vochtige duinvalleien - kalkrijk' (H2190B) zal in de scenario's met $50 \mathrm{~cm}$ getij RSV, RSV-springtij, RSV Peilbeheer en RSV Zeespiegelstijging naar verwachting met respectievelijk $11-14 \%, 13-16 \%, 36-40 \%$ en $45-48 \%$ overspoelen door het getij. Bij het scenario met $30 \mathrm{~cm}$ getij is dit $6-7 \%$.

\section{Verandering in terrestrische natuurwaarden}

Introductie van getij leidt tot een verlies aan terrestrische natuurwaarden, met name ten aanzien van de op Europese schaal relatief zeldzame vochtige duinvalleivegetaties en hun overgangen naar zoute vegetaties, met een hoge rijkdom aan soorten, waaronder verreweg de grootste populatie van de groenknolorchis in ons land. Deze vegetaties zijn geleidelijk ontstaan in de afgelopen decennia en kunnen bij voortzetting van het huidige beheer waarschijnlijk nog enkele decennia voortbestaan, totdat verdere bodemontwikkeling deze begroeiingen beperkt tot de locaties waar kalkrijk kwelwater uittreedt in of over het maaiveld. De vochtige duinvalleivegetaties zullen naar verwachting niet of slechts in zeer beperkte mate op kunnen schuiven naar hoger gelegen delen omdat er geen plek is door aanwezigheid van struweel, stuifruggen, oude schorranden, ruigten etc. Daar waar wel ruimte is zal de vegetatie slechts voor een klein deel kunnen opschuiven door het ontbreken van de juiste omstandigheden op deze hoger gelegen delen (voedselrijkdom, verzuring, bodemvorming en het ontbreken van kalkrijke kwel). De verliezen zullen dan ook groter zijn dan de modelanalyse aangeeft. Op basis van expertkennis wordt bij scenario 3 met $30 \mathrm{~cm}$ getij een achteruitgang van 10 tot 30\% van de oppervlakte ingeschat voor habitattype Vochtige duinvalleien - kalkrijk (H2190B, en een wat hoger percentage voor de beschermde groenknolorchis, die met name in de laagste delen van de duinvalleien voorkomt. Bij groter getijverschil (scenario RSV, $50 \mathrm{~cm}$ ) neemt de achteruitgang van de vochtige duinvalleien toe (naar schatting 40-60\%) en verdwijnt naar verwachting de populatie groenknolorchis grotendeels. De verliezen aan duinvalleivegetatie en groenknolorchis worden hoger ingeschat dan bij voorgaande studies (Van de Haterd et al. 2010; RoyalHaskoning DHV 2017), omdat de oppervlakte van de vegetatie en de populatie van de orchidee inmiddels groter zijn dan uit de gebruikte (oude) gegevens blijkt, en deze zich concentreren in de zones die het meest direct en indirect beïnvloed worden door invoer van getij. Naar ons inzien zijn de inschattingen in de andere studies voor deze vegetatie en plantensoort dan ook te optimistisch.

Voor zilte pioniervegetatie wordt - in tegenstelling tot de eerder positieve trend in RoyalHaskoning DHV (2017) - eveneens een verlies ingeschat, als gevolg van erosie en vorming van klifjes waarmee het oppervlakte geschikt leefgebied afneemt en omdat er in de eerste instantie hoger in de zonering weinig onbegroeide delen aanwezig zijn. Pas op de iets langere termijn, na afsterven van het planten materiaal kunnen zilte pioniersoorten hier mogelijk wel vestigen. Het verlies van dit habitat kan echter sterk gecompenseerd worden door het hanteren van een lager zomerpeil. RoyalHaskoning DHV (2017) vindt geen sterke relatie tussen het voorkomen van zilte pionierbegroeiingen met zeekraal en terreindelen waar het waterpeil in de zomer is verlaagd. Op de Slikken van Flakkee Noord is een grote oppervlakte van deze begroeiingen waargenomen op dergelijk platen. De oppervlakte van dit pioniertype is sterk onderhevig aan jaarlijkse fluctuaties, wat het monitoren van veranderingen en inschatten van effecten bemoeilijkt.

De variatie in waterstand als gevolg van getij en/of peilbeheer is tevens van invloed op de zoetwaterbellen in de bodem van de eilanden en oevers en daarmee dus ook de grondwaterstand die van belang is voor vegetatie. Hoe de grondwaterstand zich gaat ontwikkelen is niet eenduidig te voorspellen voor het hele gebied maar hangt af van verschillende processen gerelateerd aan onder andere de mate van infiltratie van zoet en zout water in de bodem en drainage bij laag water. Uit de modellering komt naar voren dat de terrestrische zone met zoutinvloed in alle scenario's zal toenemen ten opzichte van de huidige situatie. In hoofdstuk 6 wordt echter ingeschat dat het areaal van zilte vegetaties zal afnemen (zowel pionier begroeiingen met zeekraal als zilte graslanden). De zone 'terrestrisch met zoutinvloed' is ingeschat op basis van de ligging van de huidige zone met zilte 
vegetaties met gegevens van Bureau Waardenburg als proxy voor hoe ver de zoutinvloed reikt door windopzet, spatwater/zoutspray. Een deel van deze vegetatie betreft zilte graslanden die nu nog beïnvloed worden door brak/zout grondwater maar geleidelijk in areaal afnemen door de geleidelijke uitbreiding van de zoetwaterbel en overgaan in zoetminnende vegetaties: een proces wat nog steeds gaande is na de afsluiting van het Grevelingenmeer. Daarnaast is de verwachting dat het areaal met zilte pionierbegroeiingen mogelijk minder groot zal zijn door erosie en klifvorming en het areaal intergetijdengebied een beetje uitbreiden. Deze twee processen samen zorgen voor een overschatting van de gemodelleerde waarden van het areaal aan zilte vegetaties ('terrestrisch met zoutinvloed').

Bij introductie van gedempt getij zal ook huidig habitat voor broedvogels (laaggelegen delen van o.a. Slikken van Bommenede, Markenje en de Slikken van Flakkee) verloren gaan door overspoeling. De verwachting is dan ook dat het aantal broedparen zal afnemen. Een kwetsbaar punt is het verlies van brede kale zones door getijoverspoeling welke van belang zijn voor solitair broedende vogels zoals de Strandplevier; een smalle strook is minder geschikt als broedgebied. Bij invoering van $30 \mathrm{~cm}$ getij (scenario 3) zal het verlies van broedgebied beperkter zijn dan bij $50 \mathrm{~cm}$ getij (scenario 1). Het verlies is deels te compenseren door eerder genoemde maatregelen in paragraaf 6.4 (bv. opspuiten eilanden, ophogen maaiveld, aanleg drijvende voorzieningen (eilandjes) met zand en schelpengruis), maar dit zal niet voor alle soorten voldoende zal zijn.

Het Grevelingenmeer is van bijzondere betekenis voor de Strandplevier in het Deltagebied. Deze in Nederland zeldzame soort zal daarom zeker teruglopen in aantallen als gevolg van gedempt getij. Mogelijk dat peilbeheer kan helpen om kale zones langs de Slikken van Flakkee te creëren om de achteruitgang te remmen. Echter, het is ook goed om deze populatie vanuit een internationaal perspectief te bekijken. De grootste populaties van deze soort broeden in zuidwest Europa en in Azië, en Nederland heeft maar een klein aantal in de wereldwijde populatie.

\section{Ontwikkeling watersysteem bij gedempt getij}

Invoering van gedempt getij zal positieve gevolgen hebben voor de natuurwaarden van het open water. Door afname van zuurstofloosheid bij de bodem zal een groter areaal leefgebied (ook in de zomer) beschikbaar zijn voor bodemdieren. De verwachte toename in primaire productie en waterbeweging zal ervoor zorgen dat er meer voedsel beschikbaar komt waarvan naar verwachting vooral bodemdieren (schelpdieren) zullen profiteren en mogelijk ook vissen en vogels. Hoe dit precies gaat verlopen is op dit moment nog moeilijk te voorspellen al biedt het volgen van de verandering in het oostelijk deel na opening van de Flakkeese Spuisluis de mogelijkheid om hiermee ervaring op te doen. Hieronder worden een aantal facetten rond ecologisch functioneren en het voedselweb op een rijtje gezet.

Zuurstofconcentratie bij gedempt getij: In de huidige situatie is een groot deel van de diepe geulen en diepe putten langdurig zuurstofarm. Modelanalyse wijst uit dat een relatief beperkt getij van $30 \mathrm{~cm}$ (scenario 3) al een aanzienlijke afname van het zuurstofarme areaal oplevert (van 1640 ha naar 870 ha). Het zuurstofarme areaal bij Dreischor is verminderd maar nog wel aanwezig en de zuurstofarme periode is korter. Met $50 \mathrm{~cm}$ getij (scenario 1) neemt het zuurstofarme areaal nog verder af (naar 580 ha) en is het areaal beperkt tot de diepe putten ten oosten van de Brouwerssluis bij Scharendijke en Den Osse. Bij nog meer getij stopt feitelijk de afname van het zuurstofarme areaal. Bij zeespiegelstijging neemt het zuurstofarme areaal iets toe (660 ha), vermoedelijk omdat de diepte van het meer toeneemt. In Nolte \& Lagendijk (2016) wordt gesteld dat in sommige jaren met veel wind en lage zomertemperaturen $25 \mathrm{~cm}$ getij genoeg zou kunnen zijn, terwijl in andere jaren met weinig wind en hoge zomertemperaturen $50 \mathrm{~cm}$ getij nodig is. Daarom hanteren Nolte \& Lagendijk (2016) het uitgangspunt van $50 \mathrm{~cm}$ getij om het risico op het niet halen van het streefbeeld klein te houden. $50 \mathrm{~cm}$ getij is echter geen garantie dat zuurstofarme condities niet meer zullen voorkomen. Het model laat verder zien dat met meer dan $50 \mathrm{~cm}$ getij nog maar een beperkte verdere afname van het zuurstofarme areaal wordt behaald. De diepe putten bij Scharendijke en Den Osse blijven gevoelig.

Primaire productie: In de huidige situatie is primaire productie in het Grevelingenmeer stikstofgelimiteerd in het late voorjaar en de zomer (mei-augustus). In het vroege voorjaar (april) kan korte tijd fosfaat-limitatie voorkomen. De modelanalyse wijst uit dat er een forse toename in primaire productie te verwachten is in de gemodelleerde scenario's ten opzichte van de huidige situatie. Dit is te verklaren doordat zowel in de Voordelta als in de Oosterschelde de stikstofconcentratie (iets) hoger ligt dan in het Grevelingenmeer. Door de uitwisseling met Voordelta en Oosterschelde is meer stikstof beschikbaar voor algengroei. Bij $30 \mathrm{~cm}$ getij (scenario 3) is het concentratieverschil tussen Voordelta en Oosterschelde en het Grevelingenmeer al zodanig afgenomen, dat meer getij nog maar een relatief 
kleine verdere toename laat zien in primaire productie. In het intergetijdengebied (en ondiep sublitoraal) zal het microphytobenthos ook een belangrijke primaire producent zijn, die tevens van belang is voor de hogere trofische niveaus.

Vertroebeling door opwervelling van slib vanaf de bodem bij gedempt getij: Nadere analyse en discussie met experts heeft uitgewezen dat het risico op langdurige vertroebeling van het systeem naar alle waarschijnlijkheid klein is.

Doorwerking in het voedselweb: Algen (fytoplankton, microfytobenthos) vormen het laagste trofische niveau in het voedselweb en vormen voedsel voor allerlei soorten zoals kleine in het water zwevende organismen, zoöplankton, en voor bodemdieren en sommige vissoorten die weer een voedselbron vormen voor vogels en zeezoogdieren. De verwachting is dat de toename in primaire productie (fytoplankton) en waterbeweging voornamelijk ten goede komt aan bentische filterfeeders (filtrerende bodemdieren), mede ook door toename van areaal aan leefgebied door afname van de zuurstofproblematiek. De schelpdieren zullen de belangrijkste groep vormen maar ook andere filterfeeders zoals zakpijpen, sponzen, en anemonen kunnen profiteren van de toegenomen productie. Dit zou ten koste kunnen gaan van het zoöplankton, een belangrijke voedselbron voor sommige vissoorten, vanwege concurrentie om de algen. Ook de rol van (rib)kwallen, die zich voeden met zoöplankton en in grote aantallen voorkomen in het Grevelingenmeer, en daarmee concurrent zijn van allerlei vissoorten die zich ook met zoöplankton voeden, is nog onvoldoende bekend. Over de verwachte veranderingen in de visstand en de rol van het Grevelingenmeer als paaiplaats, kinderkamer, migratieroute, etc. voor vispopulaties zijn experts dan ook niet helemaal eensgezind. Enerzijds wordt gesteld dat er geen reden is om aan te nemen dat de visstand van pelagische soorten als Haring en Sprot, die nu een groot deel van de visbiomassa bepalen, sterk zal toenemen bij invoering van getij. Anderzijds zullen door het vergroten van de connectiviteit met de Noordzee door het doorlaatmiddel in het noordelijk deel van de Brouwersdam meer mariene vissoorten het Grevelingenmeer inzwemmen. Ook zal de invoering van gedempt getij, door verbetering van de waterkwaliteit, naar verwachting gunstig zijn voor bodemvissen die, hoewel beperkt in biomassa, wel de groep is met de grootste soortenrijkdom. Een eventuele toename van pelagische vissen in het Grevelingenmeer zou gunstig zijn als voedsel voor broedvogels als de grote stern, dwergstern en visdief. De verwachte toename in bodemvissen is in ieder geval gunstig voor soorten als fuut, geoorde fuut, kleine zilverreiger en lepelaar.

\section{Ecologische ontwikkeling van intergetijdengebieden bij gedempt getij}

Door de invoering van gedempt getij zullen naar verwachting laagdynamische intergetijdengebieden ontstaan die doorgaans hoogproductief zijn met een rijk bodemdierenleven (vergelijkbaar met de Oosterschelde). Algehele verwachting is dat biomassa en diversiteit van bodemdieren hierdoor zal toenemen en dat het intergetijdengebied waardevol foerageergebied zal zijn voor foeragerende vogels zoals allerlei soorten steltlopers. Dit geldt met name voor het permanente intergetijdengebied. Het "zomer intergetijdengebied", dat in de winter permanent onder water staat, en met name het "winter intergetijdengebied", dat in de zomer droogvalt (beide ontstaan in Scenario 4 'RVS-Peilbeheer'), zullen duidelijk van mindere kwaliteit zijn en minder bijdragen aan het areaal foerageergebied voor steltlopers. In het scenario RSV-Springtij ontstaat een smalle zone schor ecotoop tussen de springtij en doodtij grens $(10 \mathrm{~cm})$. Naar verwachting zal zich hier echter geen volwaardig schor ontwikkelen met kenmerkende vegetatie zonering en geulenstelsel omdat de getijslag te klein is hiervoor. Wel zullen zich in deze zone zilte pioniers en zilte vegetaties ontwikkelen.

\subsection{Terrestrische natuurwaarden versus natuurwaarden van open water}

De scenario's die zijn uitgewerkt in deze studie laten de gevolgen van verschillend waterbeheer voor natuurwaarden zien. Zo is er voor ieder scenario een winst en een verlies kant te benoemen. Een gedempt getij van $30 \mathrm{~cm}$ (scenario 3 'Getij30') leidt tot een kleiner verlies van terrestrische natuurwaarden dan $50 \mathrm{~cm}$ getij (scenario 1 'RSV'). Tegelijkertijd zal bij $30 \mathrm{~cm}$ getij tijdens warme zomers met weinig wind een groter areaal van de bodem van het meer zuurstofloos worden dan bij 50 $\mathrm{cm}$ getij. Dit zal van jaar tot jaar verschillen. Ook is het areaal intergetijdengebied dat ontstaat beperkter bij $30 \mathrm{~cm}$ getij, wat minder foerageergebied voor bijv. steltlopers oplevert. Scenario 4 'RSV-Peilbeheer' geeft een peilbeheer weer met een groot verschil tussen zomer en winterpeil $(36 \mathrm{~cm})$. Experts en gebiedsdeskundigen hebben aangegeven dat een peilbeheer met een geringer verschil en tweemaal per jaar een incidentele opzet beter ten goede komt aan ontwikkeling van broedvogelhabitat en zoute 
vegetaties (zie Hoofdstuk 7). Het laatste scenario, scenario 5 'RSV-zeespiegelstijging' projecteert de gevolgen van maximale zeespiegelstijging van $40 \mathrm{~cm}$ in 2050 . Dit scenario geeft daarmee inzicht in de houdbaarheid van terrestrische natuurwaarden.

Waar terrestrische natuurwaarden verloren gaan zullen natuurwaarden van het open water (incl. intergetijdengebieden) profiteren van het invoeren van gedempt getij. In dit rapport wordt de winst en verlies van natuurwaarden aangegeven van de verschillende scenario's die in deze studie zijn uitgewerkt. Het bepalen van het 'beste' scenario voor natuurwaarden is een politieke en maatschappelijke afweging.

\subsection{Optimalisatie natuurwaarden door een aangepast waterbeheer}

Uit deze studie en de bijeenkomsten met de betrokkenen en experts komt duidelijk naar voren dat gerichte sturing van het doorlaatmiddel mogelijkheden biedt tot het optimaliseren van bepaalde natuurwaarden:

- Instelling van een "asynchroon getij" waarbij het getij op het Grevelingenmeer enkele uren achterloopt t.o.v. bv. de Oosterschelde biedt mogelijk meerwaarde voor overtijende steltlopers uit de Oosterschelde en Voordelta doordat gedurende langere periodes gefoerageerd kan worden op geschikt voedsel.

- Vloeddominant getij met een lange eb-fase (snel op, langzaam af) biedt voordelen voor foeragerende vogels omdat bodemdieren in een dun laagje water vaak nog actief en relatief makkelijker te vangen zijn.

- Peilbeheer met een lager zomerpeil en een hoger winterpeil is gunstig voor het creëren van kale zones ten bate van kustbroedvogels van kale gronden en zilte pioniervegetaties. Een peilbeheer van bijvoorbeeld $-0,20 \mathrm{~m}$ NAP (+/- $5 \mathrm{~cm}$ peilfluctuatie) in de winter en $-0,25 \mathrm{~m} \mathrm{NAP}(-5 \mathrm{~cm}$ peilfluctuatie) met een incidentele opzet van het peil tot $+0,06 \mathrm{~m}$ NAP in de late zomer (september) en het vroege voorjaar (maart) is gunstig.

\subsection{Onzekerheden en beperkingen van dit onderzoek}

Een beperking van deze studie is dat niet alle onderwerpen konden worden uitgediept door de focus op bepaalde speerpunten. Zo zijn bijvoorbeeld ontwikkeling van zeegras, zeezoogdieren en hardsubstraatsoorten niet meegenomen in dit onderzoek.

Een belangrijke beperking van dit onderzoek is de onzekerheid van het verloop van de ondiepe oevers tussen - 0,20 en -1,50 m NAP. Het verloop van de oevers is geïnterpoleerd om toch een ruwe inschatting te kunnen maken. De resultaten geven hierdoor echter geen nauwkeurig beeld van de oppervlakten van ecotopen op het grensvlak van land en water: ondiep water, terrestrisch en (toekomstig) intergetijdengebied. Daarom moet voorzichtigheid geboden worden bij het interpreteren van de resultaten omdat deze slechts de globale verschuivingen van ecotopen in een stagnante en verschillende scenario's van een getijdensituatie aangeven. Het ontstaan van intergetijdengebieden wordt in werkelijkheid ook bepaald door kleine hoogteverschillen van de oever, aanwezigheid van dammetjes etc. waardoor sommige delen wellicht als intergetijdengebied worden geprojecteerd daar waar dit gebied in werkelijkheid niet onder water loopt doordat het omringd is door een dammetje, zandbank of wal, etc. Daar is het beter om te spreken van potentiele intergetijdengebieden.

Daarnaast is het van belang om te benadrukken dat de ecotopenkaarten die in deze studie zijn gemaakt statische begrenzingen aangeven die in werkelijkheid dynamisch zijn (bv. door fluctuerende waterstanden als gevolg van windopzet etc.) en dat ze geen inzicht geven in de verwachte kwaliteit en ontwikkeling van natuurwaarden in de tijd.

Verder sluiten de gemodelleerde ecotopen niet goed aan bij de terrestrische ecotopen. Voor terrestrische ecotopen spelen andere factoren dan alleen hoogteligging een rol, namelijk bodemtype en -ontwikkeling, ligging en omvang van de zoetwaterbel en het gevoerde beheer (niets doen versus begrazen en maaien). Om die reden zijn de effecten van de verschillende getij-scenario's sterk gebaseerd op expert-kennis. Een tweede probleem bij het inschatten van de effecten is dat de beschikbare vlakdekkende vegetatiegegevens inmiddels sterk verouderd zijn. 
In de huidige studie is gebruik gemaakt van habitatkaarten uit 2011 en 2013 die gebaseerd zijn op vegetatie karteringen die zijn uitgevoerd in 2001, 2004 en 2006 en luchtfoto interpretatie uit 2011. In de aanvulling op de natuureffecten studie zijn dezelfde gegevens van 2006 en eerder gebruikt.

Met name de omvang en ligging van duinvallei-vegetaties is inmiddels sterk veranderd. Het diepte profiel in de huidige modellering wijkt mogelijks af van het diepte profiel gebruikt in de Natuureffectenstudie, wat eveneens tot klein verschillen in effecten leidt. Op basis van expert-kennis is er verder twijfel bij de in de Natuureffectstudie genoemde uitbreiding van H1310A, zoals in paragraaf 9.2 is besproken.

Rondom de modellering van de waterkwaliteit en in het bijzonder de zuurstofuitputting zijn de onzekerheden relatief beperkt. In Nolte \& Lagendijk (2016) wordt de onzekerheid in de modelresultaten als volgt beschreven: "Op basis van de beschikbare kennis gebaseerd op modelberekeningen is niet met zekerheid aan te geven hoeveel getij er nodig is om ervoor te zorgen dat in alle jaren (dat wil zeggen onder alle meteorologische condities) aan het streefbeeld (max. 5\% zuurstofarm areaal) wordt voldaan. In sommige jaren met veel wind en lage zomertemperaturen zou $25 \mathrm{~cm}$ getij genoeg kunnen zijn, terwijl in andere jaren met weinig wind en hoge zomertemperaturen $50 \mathrm{~cm}$ getij nodig is. Het uitgangspunt van $50 \mathrm{~cm}$ getij bevat daarom een onzekerheidsmarge om het risico op het niet halen van het streefbeeld klein te houden. $50 \mathrm{~cm}$ getij is echter geen garantie dat zuurstofarme condities nooit meer zullen voorkomen." Het model laat zien dat meer dan $50 \mathrm{~cm}$ getij nog maar een beperkte verdere afname van het zuurstofarme areaal laat zien. De diepe putten bij Scharendijke en Den Osse blijven gevoelig.

\subsection{Aanbevelingen voor vervolgstudies}

De ecologische en biologische verschuivingen die hebben plaatsgevonden na de afsluiting van het Grevelingenmeer worden nog altijd niet volledig begrepen. Bij invoering van gedempt getij zal het ecosysteem opnieuw veranderingen ondergaan. Om inzicht te krijgen in bijv. mogelijke verschuivingen in ontwikkeling van de schelpdierbestanden, visstand, visetende vogels, etc. is het van belang om het systeem als geheel onder de loep te nemen en te weten wat er gebeurt aan de basis van het voedselweb (primaire productie) en hoe zich dit doorvertaalt naar de hogere trofische niveaus (zooplankton, bodemdieren, vissen, vogels, zeezoogdieren). Voldoende gegevens hierover ontbreken echter, voornamelijk van de lagere trofische niveau's zoals hiervoor genoemd.

Aanbevelingen die uit deze studie en uit de bijeenkomsten met de experts naar voren komen zijn:

- Een belangrijke beperking van dit onderzoek is de onzekerheid van het verloop van het hoogteprofiel van de ondiepe oevers tussen -0,20 en -1,50 m NAP. Het verloop van de oevers is geïnterpoleerd (op basis van een combinatie van de diepteloding van het gebied en het Actueel Hoogtegestand $(\mathrm{AHN})$ ) om zo een ruwe inschatting te kunnen maken van het profiel. De resultaten geven hierdoor echter geen nauwkeurig beeld van de oppervlakten van ecotopen op het grensvlak van land en water: ondiep water, terrestrisch en (toekomstig) intergetijdengebied. Een gedetailleerde (bathymetrie)opname van deze zone is dan ook noodzakelijk en in vervolgonderzoek kunnen dan de veranderingen in arealen met meer nauwkeurigheid worden berekend. Naast meer nauwkeurige diepte gegevens zouden dan ook geactualiseerde hoogte gegevens kunnen worden gebruikt van het Grevelingemeer die in 2014 beschikbaar zijn gekomen (AHN3).

- $\quad$ Er is op korte termijn behoefte aan één geactualiseerde, vlakdekkende Natura2000 habitatkaart die gebaseerd is op recente inventarisaties en die is goedgekeurd door het ministerie van Landbouw, Natuur en Innovatie. Momenteel circuleren er twee verschillende kaarten die op verschillende, deels verouderde, gegevens zijn gebaseerd en dit maakt het inschatten van effecten en vergelijken met andere studies erg lastig. Deze nieuwe kaart kan tevens dienen als beschrijving van de T0-situatie waaraan de effecten van gedempt getij op de Natura 2000habitattypen en soorten kunnen getoetst worden.

- $\quad$ Het Kabinetsbesluit en daarop volgende planuitwerkingsfase van de RSV richting realisatie (op zijn vroegst in 2023) moet benut worden om nader onderzoek te doen en optimalisatie/compensatie/mitigatie mogelijkheden nader te verkennen. Uit de expertsessie op 16 november 2017 kwam de aanbeveling naar voren om de Flakkeese Spuisluis te benutten om 
invoering van micro-getij op beperktere schaal te testen. Bijvoorbeeld door een klein getij van $10 \mathrm{~cm}$ toe te laten (binnen de marges van het Peilbesluit) en te experimenteren met waterstanden, peilbeheer en veranderingen in hydromorfologie en ecologie te monitoren. Vanzelfsprekend hoort hier ook een zorgvuldig omgevingsmanagement bij.

- $\quad$ Studie naar mitigerende maatregelen en hun effectiviteit om (gewenste) natuurwaarden in het Grevelingenmeer op korte en lang termijn te behouden of te ontwikkelen.

- De laatste bekkenrapportage is uitgevoerd in 2011. Gerelateerd aan de vorige twee aanbevelingen zou het een logische eerste stap zijn om eerst de bestaande kennis en data uit monitoring van de afgelopen jaren te analyseren en te bundelen in een systeemrapportage voor het Grevelingenmeer gericht op zowel de natte als droge natuurwaarden.

- $\quad$ Een aanbeveling is om op basis van de systeemrapportage een intensief meetjaar te plannen om beter grip te krijgen op de huidige situatie en causale verbanden te onderzoeken tussen de verschillende fysische, morfologische en ecologische processen en daarbijhorende biodiversiteit. Dit geldt met name voor het watersysteem. Hoe meer je tegelijk meet, hoe groter de meerwaarde van iedere meting afzonderlijk. Zo kun je elke meting in een groter verband plaatsen en causale verbanden onderzoeken van zaken die nu onzeker zijn en het gissen is naar een verklaring zoals bijvoorbeeld de mogelijke rol van het zoöplankton in relatie tot vissen en vogels. Dit zou een excercitie van meerdere kennisinstellingen, universiteiten en andere kennispartners kunnen zijn. Dan zou je echt een stap vooruit kunnen maken.

- Optimaliseren oeververdedigingen met 'nature-based solutions': nu zijn de oeververdedigingen aangelegd met breukstenen. Er zijn tegenwoordig mogelijkheden om dit op een andere, meer natuurvriendelijke manier te doen. Dit kan door andere substraattypes te gebruiken die de biodiversiteit van het harde substraat verhogen, dan wel met riffen van bv. oesters.

\subsection{Kennislacunes en kennisvragen}

Tot slot zijn naast aanbevelingen voor vervolgstudies tijdens de uitvoering van deze studie een aantal concrete kennislacunes en kennisvragen gedefinieerd die hieronder staan beschreven. Onderscheid wordt gemaakt tussen de huidige situatie/autonome ontwikkeling en een mogelijk toekomstige situatie met gedempt getij.

\section{Huidige situatie en autonome ontwikkeling}

- Hoe ziet de soortensamenstelling en biomassa van het fytoplankton er uit en wat leert dit ons over de waterkwaliteit?

- Hoe groot zijn de huidige schelpdierbestanden (natuurlijk en kweek)? Hoe verhoudt zich dit tot de andere Deltawateren en wat veroorzaakt eventuele verschillen?

- Hoe werkt de primaire productie en de fytoplankton samenstelling door naar andere soortengroepen voor soortensamenstelling en biomassa: zoöplankton, (rib)kwallen, bodemdieren en in het bijzonder schelpdieren, en de hogere trofische niveau's vissen en vogels?

- Hoe ziet de soortensamenstelling en biomassa van het zoöplankton er uit en wat leert dit ons over aan-/afwezigheid en biomassa van vissoorten?

- Hoe hebben bodemdieren (soortendiversiteit en biomassa) zich ontwikkeld in de afgelopen jaren en wat leert dit ons over het watersysteem?

- Waarom concentreert de (pelagische en juveniele, vnl. haring en sprot) visbiomassa zich voornamelijk in het westen van het Grevelingenmeer en trekken deze vissen niet verder het meer op?

- Waarom gaan aantallen van sommige visetende vogelsoorten achteruit?

- Hoe ontwikkelen de duinvallei-vegetaties zich bij het huidige beheer en verder optredende bodemvorming? 
- Welke soortensamenstelling en biomassa van fytoplankton kan worden verwacht bij invoering van getij? Ontstaat er ook een vergrote kans op bloei van schadelijke algen (bv. Phaeocystis)?

- Wat gebeurt er met opgeslagen nutriënten (zoals fosfor in de bodem) bij invoering van gedempt getij?

- Hoe werkt de verwachte toename in primaire productie door naar andere soortengroepen voor soortensamenstelling en biomassa: zoöplankton, bodemdieren, vissen en vogels?

- Wat wordt verwacht van de (snelheid van) ontwikkeling van bodemdieren (soorten en biomassa) in de toekomstige intergetijdengebieden op basis van beschikbare kennis en welke vogelsoorten zullen hiervan met name profiteren? Wordt de vestiging en ontwikkeling van bodemdieren gehinderd door de nog aanwezige (afstervende) vegetatie?

- Een grote onzekerheid in dit onderzoek is het bodemprofiel tussen -0,20 en -1,5 meter NAP. Daardoor geven de ecotopenkaarten geen realistisch oppervlak van de intergetijdengebieden weer. Het is van belang het bodemprofiel in deze zone in kaart te brengen zodat arealen potentieel intergetijdengebied nauwkeuriger kunnen worden berekend en geëvalueerd.

- Hoe ontwikkelt de zone met zoutspray zich in een getijdensituatie en tot waar treden significante effecten op voor vegetaties? Wat is het effect van een mogelijk wisselend peilbeheer hierop?

- Wat is de exacte ontwikkeling van de zoete grondwaterlenzen en bodemcondities in een getijdensituatie? Hiervoor is nader eco-hydrologisch onderzoek nodig.

- In hoeverre kunnen zoete en zoute vegetaties naar boven opschuiven? Wat zijn de verschillen in ontwikkelingen tussen deelgebieden (verschillen tussen eilanden, oevers)?

- Hoe ontwikkelt de populatie van de groenknolorchis zich in relatie tot hoogteligging, waterhuishouding, bodemvorming en beheer? 


\section{Dankwoord}

Onze dank gaat uit naar de mensen van (natuur)organisaties verenigd binnen Coalitie Delta Natuurlijk, Natuur en Vogelwacht Schouwen-Duiveland, Natuur en Landschap Goeree Overflakkee, Werkgroep Beter Zicht op de Grevelingen, beheerders van Rijkswaterstaat en Staatsbosbeheer en deskundigen van Delta Project Management, Bureau Stroming, Deltares, Bureau Waardenburg en B2Consultancy zonder wiens waardevolle inbreng voorliggende rapportage nooit tot stand had kunnen komen. 


\section{Kwaliteitsborging}

Wageningen Marine Research beschikt over een ISO 9001:2008 gecertificeerd kwaliteitsmanagementsysteem (certificaatnummer: 187378-2015-AQ-NLD-RvA). Dit certificaat is geldig tot 15 september 2018. De organisatie is gecertificeerd sinds 27 februari 2001. De certificering is uitgevoerd door DNV Certification B.V. Als onderdeel van de kwaliteitsborging een review procedure gevolgd waarbij dit rapport getoetst wordt door een collega die niet betrokken is geweest bij het onderzoek. 


\section{Literatuur}

Alterra Wageningen UR, 2011. Habitatkaarten van Natura 2000-gebieden met Rijkswaterstaat als bevoegd gezag

Anonymus (2009). Atlantische schorren (Glauco-Puccinellietalia maritimae) (H1330).

Arts, F. A., S. J. Lilipaly, M. S. J. Hoekstein, K. D. van Straalen, P. A. Wolf \& L. Wijnants (2016). Kustbroedvogels in het Deltagebied in 2016. Delta Project Management, Vlissingen.

Arts, F. A., S. J. Lilipaly, M. S. J. Hoekstein, K. D. van Straalen, P. A. Wolf \& L. Wijnants (2017). Watervogels en zeezoogdieren in de Zoute Delta in 2015/2016. Delta Project Management, Vlissingen.

Beeftink, W. G. (1965). De zoutvegetatie van ZW-Nederland beschouwd in Europees verband. H. Veenman \& Zonen n.v., Wageningen. 167

Bolier, A. \& B. Odé (2003). Groenknolorchis op de kaart. Gorteria 29: 33-37.

Bouma, H., D. J. De jong, F. Twisk \& K. Wolfstein (2005). Zoute wateren EcotopenStelsel (ZES.1). Voor het in kaart brengen van het potentiële voorkomen van levensgemeenschappen in zoute en brakke rijkswateren. RIKZ, Middelburg. Rapport RIKZ/2005.024

Bouma, S., W. Lengkeek, T. J. Boudewijn, L. G. Turlings, R. Abma \& R. L. J. Nieuwkamer (2008). Notitie knelpunten autonome ontwikkeling, onderdeel verkening "Grevelingen water en getij". Ministerie van Verkeer en Waterstaat: 47

Bureau Waardenburg, 2013. Ecotopenkartering 2011 van de zoute meren Grevelingen en Veerse Meer $1: 10.000$. Inclusief zoutgradiënt en habitattypen.

Camphuysen, C. J. \& K. Heijboer (2008). Bruinvis Phocoena phocoena in het Grevelingenmeer: een bijzonder geval met afwijkend gedrag. Zeezoogdieren - Marine Mammals: 74-85

Cozzoli, F., S. Smolders, M. Eelkema, T. Ysebaert, V. Escavarage, S. Temmerman, P. Meire, P. Herman \& Bouma, T. (2016). A modeling approach to assess coastal management effects on benthic habitat quality: a case study oncoastal defense and navigability. Estuarine, Coastal and Shelf Science. 184: 67-82

Craeymeersch, J. A. M. \& I. De Vries (2007). Waterkwaliteit en ecologie Veerse Meer: het tij is gekeerd. Eerste evaluatie van de veranderingen na de ingebruikname van de 'Katse Heule' op basis van waarnemingen juni 2004- juni 2006. Rijksinstituut voor Kust en Zee, Middelburg.

Dankers, N., W. van Duin, M. Baptist, E. Dijkman, J. Cremer \& E. K. Baker (2012). 11 - The Wadden Sea in the Netherlands: Ecotopes in a World Heritage Barrier Island System A2 - Harris, Peter T. Seafloor Geomorphology as Benthic Habitat. London, Elsevier: 213-226.

De Jong, D. \& D. Van Maldegem (2010). Invloed getij op oevers Grevelingen Meer. Huidige ontwikkeling en prognoses voor scenario's T50, T70 en T100. Rijkswaterstaat, Middelburg. 49

de Kraker, C. (2017). Grevelingenverslag: onderzoek aan flora en fauna van de Hompelvoet en andere gebieden in de Grevelingen in 2016. Sandvicensis ecologisch adviesbureau, Burgh. 95

De Vries, I. (2015). Waterkwaliteiten Deltawateren : datarapport N, P, Si; Deltares rapport 1210859, februari 2015

De Vet, P.L.M., B.C. van Prooijen \& Z.B. Wang (2017). The differences in morphological development between the intertidal flats of the Eastern and Western Scheldt. Geomorphology 281: 31-42

Didderen, K., J. H. Bergsma, F. M. F. Driessen \& W. Lengkeek (2016). De verspreiding van witte bacteriematten en schade aan het bodemleven in het Grevelingenmeer IV Zomer 2016 Nulmeting effect Flakkeese spuisluis (TO). Bureau Waardenburg, Culemborg.

Didderen, K. \& F. M. F. Driessen (2017). Verspreiding van witte bacteriematten en schade aan het bodemleven in het Grevelingenmeer V Zomer 2017 Metingen in het oostelijke deel in het eerste jaar na ingebruikname Flakkeese spuisluis (T1). Bureau Waardenburg, Culemborg.

Didderen, K., W. Lengkeek \& S. Bouma (2013). De verspreiding van witte bacteriematten en schade aan het bodemleven in het Grevelingenmeer III. Bureau Waardenburg, Culemborg.

Dienst Landelijk Gebied (2014a). Natuureffectenstudie bij de Rijksstructuurvisie Grevelingen en Volkerak-Zoommeer Deel 1: beschrijving effecten. Utrecht. 116

Dienst Landelijk Gebied (2014b). Natuureffectenstudie bij de Rijksstructuurvisie Grevelingen en Volkerak-Zoommeer Deel 2: toetsing aan de natuurwetgeving en landelijke doelen. Utrecht. 48

Gmelig Meyling AW, Van Lente I, Schrieken N, Gittenberger A, De Bruyne RH (2013) Het Duiken Gebruiken 3. Gegevensanalyse van het Monitoringproject Onderwater Oever (MOO), Faunaonderzoek met sportduikers in Oosterschelde en Grevelingenmeer. Periode 1994 t/m 2012. Stichting Anemoon

Hoeksema, H. J. (2002). Grevelingenmeer van kwetsbaar naar weerbaar? Een beschrijving van de ontwikkelingen van 1996 tot 2001 en een toetsing aan het beleid. RIKZ, Middelburg. RIKZ/2002.033

Holzhauer, H., T. Maris, P. Meire, S. Van Damme, A. Nolte, K. Kuijper, M. Taal, C. Jeuken, J. Kromkamp, B. K. Van Wesenbeeck, G. Van Ryckegem, E. Van den Bergh \& S. Wijnhoven (2011). Evaluatiemethodiek Schelde-estuarium. Fase 2. Vlaams Nederlandse Schelde Commissie (VNSC), Bergen op Zoom. 268

Hop, J. (2016). Visstand onderzoek Grevelingenmeer november 2016. ATKB,

Hop, J. (2017a). Visstandonderzoek Grevelingenmeer voor- en najaar 2017. ATKB 
Hop, J. (2017b). Visstandonderzoek Grevelingenmeer voorjaar 2017. ATKB

Houtekamer en Van Kleef, 2016: Verslag Expertsessie Effecten van een doorlaat Brouwersdam op de slibhuishouding van de Grevelingen, Rotterdam, 25 mei 2016, In opdracht van Rijkswaterstaat Zee en Delta, 20 juni 2016.

I\&M, 2014. Milieueffectrapport bij de Rijksstructuurvisie Grevelingen en Volkerak-Zoommeer. Rijkswaterstaat Zee \& Delta, Den Haag, oktober 2014.

Janssen, J. A. M. \& J. H. J. Schaminée (2009). Europese Natuur in Nederland. Natura2000-gebieden van Zee en Kust. Zeist, KNNV Uitgeverij.

Janssen, J.A.M., J.S. Rodwell, M. García Criado, S. Gubbay, T. Haynes, A. Nieto, N. Sanders, F. Landucci, J. Loidi, A. Ssymank, T. Tahvanainen, M. Valderrabano, A. Acosta, M. Aronsson, G. Arts, F. Attorre, E. Bergmeier, R.-J. Bijlsma, F. Bioret, C. Biţă-Nicolae, I. Biurrun, M. Calix, J. Capelo, A. Čarni, M. Chytrý, J. Dengler, P. Dimopoulos, F. Essl, H. Gardfjell, D. Gigante, G. Giusso del Galdo, M. Hájek, F. Jansen, J. Jansen, J. Kapfer, A. Mickolajczak, J.A. Molina, Z. Molnár, D. Paternoster, A. Piernik, B. Poulin, B. Renaux, J.H.J. Schaminée, K. Šumberová, H. Toivonen, T. Tonteri, I. Tsiripidis, R. Tzonev and M. Valachovič (2016). European Red List of Habitats. Part 2: Terrestrial and freshwater habitats. European Commission, Brussels.

Kamermans, P., M. A. Hemminga \& D. De Jong (1999). Significance of salinity and silicon levels for growth of a formerly estuarine eelgrass (Zostera marina) population (Lake Grevelingen, The Netherlands). Marine Biology 133(3): 527-539.

Kater, B. J. \& E. Van Onselen (2013). De ontwikkelingen van het macrobenthos in het Grevelingenmeer. Arcadis, Zwolle.

Leewis, L., E. C. Verduin \& J. Wanink (2013). Macrozoöbenthosonderzoek in de zoute Rijkswateren, Jaarrapportage MWTL 2013 Waterlichamen: Delta (Oosterschelde, Westerschelde, Grevelingenmeer, Veerse Meer). Grontmij, Amsterdam.

Lengkeek, W. \& S. Bouma (2011). De verspreiding van witte bacteriematten en schade aan het bodemleven in het Grevelingenmeer II (concept) Metingen van de nazomer 2010 en het eind van de winter 2011. Bureau Waardenburg, Culemborg.

Lengkeek, W., S. Bouwma \& B. Van den Boogaard (2010). De verspreiding van witte bacteriematten en schade aan het bodemleven in het Grevelingenmeer Onderzoek naar de effecten van zuurstofloosheid. Bureau Waardenburg, Culemborg.

Ministerie van Economische Zaken (2014). Natuurambitie Grote Wateren 2050 en verder. Den Haag. 75

Ministerie van Infrastructuur en Milieu (2014). Ontwerp-rijksstructuurvisie Grevelingen en VolkerakZoommeer. Den Haag. 68

Ministerie van Infrastructuur en Milieu (2015). Natura 2000 Ontwerpbeheerplan Deltawateren 20152021. Grevelingen. Den Haag. 84

Ministerie van Infrastructuur en Milieu (2016). Natura 2000 Deltawateren. Beheerplan 2016-2022. Den Haag. 104

Nienhuis, P. H. (1985). Het Grevelingenmeer: van estuarium naar zoutwatermeer. Delta Instituut voor Hydrobiologisch onderzoek, Yerseke.

Nolte, A. \& L. V. Basch (2011). Onderzoek naar de oorzaak en oplossing voor witte Beggiatoa matten op de bodem van het Grevelingenmeer. Deltares, Delft.

Nolte, A.J. en O.G. Lagendijk, (2016). Grevelingenmeer van stagnant naar beperkt getij: synthesedocument Beschikbare kennis en resterende kennisvragen met betrekking tot het effect van introductie beperkte getijslag op het natuurlijk systeem van Grevelingenmeer en Voordelta; Deltares rapport 1230426, december 2016

Nolte, A., C. J. Sprengers \& J. A. G. Van Gils (2013 ). Samenhang in de Zuidwestelijke Delta: Integrale beschouwing en kwantificering van estuariene dynamiek en waterkwaliteit. Deltares, Delft. $1208082-000$

Nolte, A. \& C. Spiteri (2011). Effect van herintroductie van getij op waterkwaliteit en ecologische toestand van het Grevelingenmeer. Scenarioberekeningen ten behoeve van de MIRTVerkenning. Deltares, Delft. 1201650-000:80

Rijkswaterstaat (2013). Peilbesluit Grevelingenmeer.

Rijkswaterstaat (2015). Natura 2000 Ontwerpbeheerplan Deltawateren 2015-2021 Grevelingen.

RoyalHaskoning DHV (2017). Aanvulling Natuureffectenstudie en MER bij de Rijksstructuurvisie Grevelingen en Volkerak-Zoommeer. Royal Haskoning DHV, Amersfoort.

Schaub, B. E. M., D. Van Oevelen, W. C. H. Sistermans, M. Rietveld, P. M. J. Herman \& H. H. Hummel (2002). Veranderingen in de Samenstelling van het Macrobenthos van het Grevelingenmeer (periode 1990-2000) en mogelijke Oorzaken. NIOO-CEME:109

Seitaj, D. (2016). Impact of cable bacteria on the biogeochemical cycling in a seasonally hypoxic basin PhD thesis, Vrije Universiteit van Brussel.

Sistermans, W., V. Escaravage, H. Hummel, A. Engelberts \& M. Markusse (2006). Het macrobenthos van de Westerschelde, de Oosterschelde, het Veerse Meer en het Grevelingenmeer in het najaar 2005. Rapportage in het kader van het Biologisch Monitoring Programma. NIOO-CEME, Yerseke.

Spiteri, C. \& A. Nolte (2010). Validatie van het 3D model van het Grevelingenmeer voor hydrodynamica, waterkwaliteit en primaire productie. Deltares, Delft. 1201650-000:56.

Stratelligence, 2014. MKBA bij Rijksstructuurvisie Grevelingen en Volkerak-Zoommeer. Leiden, juli 2014.

Temmerman, S., G. Govers, P. Meire \& S. Wartel (2003). Modelling long-term tidal marsh growth under changing tidal conditions and suspended sediment concentrations, Scheldt estuary, Belgium. Marine Geology 193: 151-169. 
Van de Haterd, R. J. W., W. Lengkeek, S. Bouma \& M. T. Collombon (2010). Herintroductie getij in de Grevelingen en effecten op natuur in intergetijdengebieden. Bureau Waardenburg, Culemborg. 10-079:75

J. van der Werf, J. Reinders, A. van Rooijen, H. Holzhauer \& T. Ysebaert (2015). Evaluation of a tidal flat sediment nourishment as estuarine management measure. Ocean \& Coastal Management 114: $77-87$

Van Kessel, T., M. R. A. Verheul \& M. A. De Lucas Pardo (2015). Resultaten bodemmonsteranalyse Grevelingen en Volkerak-Zoommeer. Deltares, Delft.

Vandenbussche, V., F. T'Jollyn, A. Zwaenepoel, E. Van Den Balck \& M. Hoffmann (2002). Systematiek van natuurtypen voor de biotopen heide, moeras, duin, slik en schor. Deel 5: slik en schor. MINA 102/99/01:149

Van Zanten, E., L.A. Adriaanse (2008). Verminderd getij. Verkenning naar mogelijke maatregelen om het verlies van platen, slikken en schorren in de Oosterschelde te beperken. Hoofdrapport Rijkswaterstaat.

Vink J.L.S. \& de Vos C.P., 1980. Interimnota. Chloride- en zuurstofstratificatie in het Grevelingenmeer in de zomerperiode 5/5/1979 - 3/9/1979. Rapport nr: DDMI-80.19, Rijkswaterstaat Deltadienst, Middelburg.

Waardenburg, H.W. (1976). Het Grevelingenonderzoek van de Biologische Werkgroep van de N.O.B. Onderwatersport (6). Nederlandse Onderwatersport Bond, utrecht.

Wattel, G. (1996). Grevelingenmeer: uniek maar kwetsbaar. De ontwikkelingen in de periode 19901995. Rijkstinstituut voor Kust en Zee, Rapport RIKZ-96.014:101

Wetsteijn, L. P. M. J. (2011). Grevelingenmeer: meer kwetsbaar. Een beschrijving van de ecologische ontwikkelingen voor deperiode 1999 t/m 2008-2010 in vergelijking met de periode 1990 t/m 1998. Rijkswaterstaat Waterdienst, Lelystad. 163

Wetsteyn, L. P. M. J. (2010). Actualistatie bekken rapport Grevelingenmeer. Rijkswaterstaat, Middelburg.

Wijsman, J., E. Brummelhuis \& A. Van Gool (2016). Monitoring mosselgroei Flakkeese Spuisluis. Resultaten T0 bemonstering 2016. Wageningen Marine Research, Yerseke.

Wijsman, J., A. Van Gool \& J. Van der Pool (2017). Monitoring mosselgroei Flakkeese spuisluis. Resultaten T1 bemonstering 2017. Wageningen Marine Research, Yerseke.

Wolff, W.J. (1973). The estuary as a habitat. An analysis of data on the soft-bottom macrofauna of the estuarine area of the rivers Rhine, Meuse and Scheldt. Zoölogische Verhandelingen (Leiden), 126: $1-242$

Ysebaert, T., L. De Neve \& P. Meire (2000). The subtidal macrobenthos in the mesohaline part of the Schelde Estuary (Belgium): influenced by man? Journal of the Marine Biological Association of the United Kingdom 80(4): 587-597.

Ysebaert, T., M. Tangelder, J. Wijsman \& K. Troost (2013a). Samenhang in de delta, ontwikkelingsvarianten voor de Zuidwestelijke Delta: Ecologische onderbouwing (deel1). IMARES Wageningen UR, Yerseke. C073/13:46

Ysebaert, T., M. Tangelder \& J. W. M. Wijsman (2013b). Samenhang in de Delta, ontwikkelingsvarianten voor de Zuidwestelijke Delta: Ecologische ontwikkeling van habitats en levensgemeenschappen (deel 2). IMARES:64

Ysebaert, T., D. J. Van der Hoek, R. Wortelboer, J. W. M. Wijsman, M. Tangelder \& A. J. Nolte (2016). Management options for restoring estuarine dynamics and implications for ecosystems: A quantitative approach for the Southwest Delta in the Netherlands. Ocean and Coastal Management 121: 33-48. 


\section{Verantwoording}

Rapportnummer C021/18

Projectnummer: 4318100123

Dit rapport is met grote zorgvuldigheid tot stand gekomen. De wetenschappelijke kwaliteit is intern getoetst door een collega-onderzoeker en het verantwoordelijk lid van het managementteam van Wageningen Marine Research.

Akkoord:

Oscar Bos

Onderzoeker

Handtekening:

Datum:

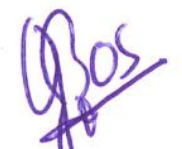

1 augustus 2018

Akkoord:

Drs. J. Asjes

Manager Integratie

Handtekening:

Datum:

1 augustus 2018 


\section{Bijlagen}

Hieronder staat een overzicht van alle Bijlagen behorend bij deze rapportage:
A. Verslag overleg met Coalitie Delta Natuur
B. Verslag overleg met Natuur en Vogelwacht Schouwen-Duiveland
C. Verslag verdiepingsworkshop Scenariostudie Grevelingenmeer met natuurpartijen en beheerders
D. Verslag overleg tussentijdse terugmelding met natuurpartijen en beheerders
E. Beschrijving OD en 3D model
F. Berekende waterstanden
G. Verslagen expertsessies
$\mathrm{H}$. Aantekeningen interview experts Bureau Waardenburg
I. Doelstellingen Natura 2000 Grevelingen
J. Doelen van de Kaderrichtlijn Water
K. Ecotopenkaarten volledige gebied
L. Ecotopenkaarten Hompelvoet
M. Ecotopenkaarten Veermansplaat
N. Verlies areaal habitattypen H1310A en H2190B
O. Vergelijking oeverprofielen 


\title{
A. Verslag overleg met Coalitie Delta Natuur
}

\section{Discussie met CDN over opzet scenario studie ecologisch perspectief}

\author{
Grevelingenmeer (BO NAGW) \\ Maandag 12 sept. 2016, WWF, Zeist
}

Deelnemers: CDN (coalitie delta natuur) + WMR
1. Gijs van Zonneveld - ARK
2. Frans van Zijderveld - Natuurmonumenten
3. Inge Both-van der Vlist - Vogelbescherming, beleidsmedewerker wetlands
4. Erik Jan van der Meer - RVO
5. Kees van der Vlugt - Stichting het Zeeuwse Landschap, bestuurder
6. Christine Röckmann - WMR
7. Alfons van Winden - Bureau Stroming
8. Bas Roels - WWF
9. Marijn Tangelder - WMR

\section{Achtergrond}

Rijksstructuurvisie traject: Dit najaar een beslissing. Verwachting:

- GM: openen voor 30-50 cm getij

- VZM: op dit moment niets

EZ: Astrid Hilgers - Natuurambitie grote wateren gebiedstrekker Zuidwestelijke Delta (ZWD)

Achtergrond documenten: Scenario studie Zuidwestelijke Delta: bv. bij variant (=scenario) Open Delta (zout) zou het GM iets zoeter worden

- Fase 1: scenario's + indicatorsoorten (Ecologische onderbouwing en vastleggen scenario's)

- Fase 2: model: optimalisatie (Habitatkaarten en ecologische interpretatie)

\section{Wensen/gedachtes van CDN m.b.t. de studie/model/scenario's}

om te checken/ mee te nemen in modellering/ scenario's

- Verbeteren van onzekere model-aannames, m.n.

- Dieptekaart VZM

- Diepte GM, juist daar waar belangrijke habitats zijn

- Traditioneel in GM veel oester- en mosselteelt

- Uitleg over: Wat kan het model modelleren?

- Bestaande MER is onvoldoende

- Wie zijn andere stakeholders?

- Aansluiting bij RSV

- Betrek lokale natuurkennis

- Cees de Kraker

- Staatsbosbeheer - ook deel van CDN, maar is ook terreinbeheerder

\section{Ideeën voor scenario's}

- Verschillen in afvoer van de Rijn

- Invloed van eb/vloed --> ca 1000 m3

- Maak ook kaarten van nutriënten/ nutriëntenverdeling (net zoals de kaarten over zoutgehalte)

- Zijn er zoutmetingen voor de afsluitingen/ het begin van de deltawerken (voor 1960)? Evt. deze meenemen voor vergelijk

- Inge Vogelbescherming: meer koppeling aan de ecologische kant: Scenario resultaten in termen van soorten, niet alleen habitat

- Doolsoorten/ Indicatorsoorten per habitat - vogels, vissen, onderwatersoorten ?

- Benoem indicatorsoorten

- WWF: 
- Moeilijk: Oesters

- Ok: Grote stern, haring

- $\quad$ Relateren ook aan oppervlak (hectares!): Hoe veel oppervlak is nodig als belangrijk habitat voor soorten?

- Kan getijdendynamiek worden vertaald van habitats naar soorten?

- Meer focus op de transitiefase: Kijk ook naar tussenstappen, niet alleen op het einddoel!

- van nu (geen getij) tot xx (open) - hoe komen we daar?

- Wat zijn de tussen-situaties van habitats?

- ArK: Hoe komen we van een beetje open tot helemaal open?

- Opbouw

- Afslag

- Erosie

- voedsel

- Hoe kan "een beetje estuariene dynamiek" nuttig zijn? Hoe zit de balans?

- Geeft model inzicht in energie van het systeem?

- WNF: Wat betekent peak signaal van getijdencentrale voor het ecosysteem?

- Effecten op doorzicht?

- Sediment: zout of minder?

- Wat als het VZM helemaal erbij trekt (samen met het GM?), of i.i.g. als het estuarien wordt / als het 2 kanten op gaat?

- Droogvalduur + areaal koppelen aan "niet incidenteel overstroomt"

\section{Huiswerk:}

- $\quad$ CDN: lijst met soorten die zijn voor hun nuttig/belangrijk zijn (mogelijke indicator soorten)

Nolte, A., C. J. Sprengers \& J. A. G. Van Gils (2013). Samenhang in de Zuidwestelijke Delta: Integrale beschouwing en kwantificering van estuariene dynamiek en waterkwaliteit. Deltares, Delft. 1208082000

Ysebaert, T., M. Tangelder, J. Wijsman \& K. Troost (2013a). Samenhang in de delta, ontwikkelingsvarianten voor de Zuidwestelijke Delta: Ecologische onderbouwing (deel1). IMARES Wageningen UR, Yerseke. C073/13:46

Ysebaert, T., M. Tangelder \& J. Wijsman (2013b). Samenhang in de Delta, ontwikkelvarianten voor de Zuidwestelijke Delta: Ecologische ontwikkeling van habitats en levensgemeenschappen (deel 2). IMARES, Yerseke. C159/13:64 


\section{B. Verslag overleg met Natuur en Vogelwacht Schouwen-Duiveland}

BIJEENKOMST

Overleg met Natuur en Vogelwacht

Schouwen-Duiveland

LOCATIE

Moriaanshoofd
DATUM

3 oktober 2016

TIJD

$19: 30-20: 30$

Aantekeningen en belangrijkste speerpunten vanuit NVSD t.b.v. de scenariostudie Grevelingenmeer:

- Bestuur is geïnteresseerd in de scenariostudie en Gert-jan komt naar de bijeenkomst op 24 oktober.

- $\quad$ Bij de mensen van het NVSD is veel deskundigheid en langjarige betrokkenheid over natuurwaarden en ecologische processen in het Grevelingenmeer.

- Wat is de invloed van deze studie op het besluit van de Rijksstructuurvisie (bv de $50 \mathrm{~cm}$ ). Antwoord: Na het besluit over de Rijksstructuurvisie komt de planuitwerkingsfase. De Rijksstructuurvisie is leidend, maar in de planuitwerking zal (beperkt)ruimte zijn om te gaan variëren. De scenariostudie moet basismateriaal leveren om op een goede manier inbreng te leveren in dat proces.

- Het is belangrijk om goed uit te leggen waarom ook niet-realistische scenario's soms toch ook onderzocht worden (uit het voorbeeld PBL).

- Het is belangrijk om goed uit te leggen waarom nu alleen de ecologische invalshoek wordt gekozen, en niet integraal, er kwam bv meteen discussie over zandhonger.

- $\quad \mathrm{Er}$ is zorg over een eventuele strategie om met kleine stapjes naar een volledig estuarien systeem te gaan, bij de kleine stapjes gaat meer aan bestaande natuurwaarden verloren dan dat er terugkomt.

- Niet tegen getij, maar wel tegen 50 centimeter (blijer met 25 centimeter)

- Wens om goed na te denken aan fluctuatie in peil t.b.v. kale grond broeders in het voorjaar (tijdelijk omlaag) en zoutminnende planten in het najaar (tijdelijk omhoog bv. 0,1 m +NAP). Door peilbeheer te optimaliseren kun je flexibeler inspelen op natuurwaarden

- Zorg om verloren gaan van (vochtige duinvallei) vegetatie.

- Zorg om mobiliseren grondwater o.g.v. getij met als gevolg afname van soorten die van schrale omstandigheden houden.

- $\quad$ Er wordt aandacht gevraagd voor de bijzondere zout-zoet overgangen op het land. Vegetaties haaks op de oever en de 'brakke zone' die daar ontwikkelt bij gedempt getij.

- De nieuwe intergetijdenzones worden zandig en te weinig voedsel, dus weinig foerageermogelijkheden -> wat is de rol van slib bij gedempt getij?

- $\quad$ Er is nu een minigetij van 6 centimeter via de Brouwerssluis

- Qua bodemleven is het Grevelingenmeer 'mager' vergeleken met Oosterschelde. 


\section{Verslag verdiepingsworkshop met natuurpartijen en beheerders}

BIJEENKOMST

AANWEZIG

Verdiepingsworkshop Scenariostudie

Grevelingenmeer

LOCATIE

AFWEZIG

Rotterdam

DATUM EN TJJD

24 oktober $2016,13: 00-16: 00$

\section{Aanwezig:}

$\begin{array}{ll}\text { Alphons van Winden } & \text { Bureau Stroming } \\ \text { Astrid Hilgers } & \text { Ministerie EZ } \\ \text { Bas Roels } & \text { WNF } \\ \text { Bernadette Botman } & \text { B2Consultancy } \\ \text { Christine Lammerts } & \text { SBB } \\ \text { Erik Jan van der Meer } & \text { RVO } \\ \text { Evert Jan Lammerts } & \text { SBB } \\ \text { Gert Jan Buth } & \text { Natuur en Vogelwacht Schouwen-Duivenland } \\ \text { Inge Both } & \text { Vogelbescherming Nederland } \\ \text { Krijn Tanis } & \text { Vereniging Natuur en Landschap Goeree-Overflakkee } \\ \text { Lora Buckman } & \text { Deltares } \\ \text { Maarten Platteeuw } & \text { RWS } \\ \text { Mariëtte Berrevoets } & \text { Provincie zeeland } \\ \text { Paul Paulus } & \text { RWS } \\ \text { Reinier Schrijvershof } & \text { Deltares } \\ \text { Sander Terlouw } & \text { SBB } \\ \text { Sebastiaan Huls } & \text { RWS } \\ \text { Jeroen Wijsman } & \text { Wageningen Marine Research } \\ \text { Arno Nolte } & \text { Deltares } \\ \text { Marijn Tangelder } & \text { Wageningen Marine Research } \\ \text { Christine Röckmann } & \text { Wageningen Marine Research (verslag) }\end{array}$

\section{Welkom}

Marijn Tangelder, WMR

Doel van het onderzoek is om het natuurperspectief van het Grevelingenmeer in verschillende inrichtingsvarianten (scenario's) te onderzoeken. Dit onderzoek wordt uitgevoerd in opdracht van het ministerie van Economische Zaken vanuit de Natuurambitie Grote Wateren. Het doel van de workshop is om gezamenlijk te bediscussiëren welke scenario's het beste kunnen worden onderzocht waarbij aansluiting wordt gezocht op de Rijksstructuurvisie Grevelingen - VZM (in het vervolg "RSV") en ook naar de lange termijn wordt gekeken.

\section{Speelruimte binnen Rijksstructuurvisie Grevelingen-VZM (RSV)}

Paul Paulus, RWS

In zijn presentatie verduidelijkt Paul Paulus de huidige problemen van het Grevelingenmeer met betrekking tot de zuurstofloosheid. In 2008 is de Pre-Verkenning naar een alternatief waterbeheer voor het Grevelingenmeer gestart. In 2010 - 2012 is dit vervolgd in de MIRT Verkenning Grevelingen en 2013-214 in de RSV. In de RSV zijn als voorkeursbesluit voor het Grevelingenmeer de volgende uitgangspunten gedefinieerd:

- Getijslag van gemiddeld $50 \mathrm{~cm}$ 
- Rondom huidig middenpeil $(-20 \mathrm{~cm})$

- 2 maal per dag eb en vloed

- Opening Noordlocatie Brouwersdam

Het terugbrengen van getij middels een doorlaat in de Brouwersdam is mogelijk te combineren met een Getijdencentrale, maar niet noodzakelijk. Doorlaatmiddel (d.w.z. instroom van zuurstofrijk Noordzeewater) is de basis. Paul legde uit dat $45 \mathrm{~cm}$ getijslag het minimum is om het zuurstof probleem op te lossen. Met minder getij is het risico te groot dat het zuurstofprobleem niet wordt opgelost; met meer getij komen huidige natuurwaarden en voorzieningen voor de recreatievaart te veel in de problemen. Onduidelijk zijn nog de effecten van het toelaten van springtij, wat ca. 10\% van de tijd kan gebeuren $(+/-5 \mathrm{~cm})$. Daar is ook nog geen besluit voor genomen. Wat de planning betreft, zou de Brouwersdam op zijn vroegst in 2023 open kunnen gaan. Het is van belang om rekening te gaan houden met zeespiegelstijging. Verder legde Paul het basisontwerp en functioneren van een mogelijke Getijdencentrale uit. Deze zou ook voor adaptief peilbeheer kunnen worden gebruikt, door het tijdelijke niet gebruiken van een aantal "kokers" of door het later verwijderen van turbines. De economische levensduur van zo een centrale is ca 30 jaar.

Als laatste besteedde Paul nog extra aandacht aan het voorkeursalternatief met $50 \mathrm{~cm}$ getijslag. Om de waterkwaliteit zoals gewenst te verbeteren zou dus op zijn minste $50 \mathrm{~cm}$ getijslag nodig zijn. Hetzelfde geldt voor ingebruikneming van een getijdencentrale.

Vanuit de zaal geeft men aan dat voor behoud van bestaande natuurwaarden een beperktere getijslag is gewenst.

\section{Discussievragen:}

- $\quad$ Aanpassing middenstand (peil)?

- Meegroeien met zeespiegelstijging?

- Springtij toelaten?

- Tijdens windermaanden peil omhoog?

- $\quad$ Tijdens broedseizoen peil omlaag?

\section{Kader Natuurambitie Grote Wateren}

Astrid Hilgers, ministerie van EZ

Astrid Hilgers legt kort uit dat er, desondanks alle eerdere studies, nog steeds veel vragen zijn. Daarom wordt nu een scenariostudie voor het Grevelingenmeer uitgevoerd gericht op perspectief voor natuurwaarden. Het ministerie van EZ vindt het van belang dat stakeholders betrokken worden maar ook dat er afstemming is met Rijkswaterstaat / ministerie van Infrastructuur \& Milieu.

\section{Introductie scenario studie}

Jeroen Wijsman, WMR en Arno Nolte, Deltares

Jeroen introduceerde het model- en scenariowerk dat er in opdracht van het Planbureau voor de Leefomgeving $(\mathrm{PBL})$ al is uitgevoerd voor het gehele Zuidwestelijke Delta. De opzet van de studie is gebaseerd op een indeling in systeemtypen (getij/stagnant, zoet/zout/brak) en habitattypen (bv. intergetijdengebied) als ecologische onderbouwing voor het modelmatige doorrekenen van verschillende inrichtingsvarianten (=scenario's). De modelberekening resulteert in habitatkaarten die een bepaalt scenario's verbeelden en een kwantitatief beeld geven (oppervlakten) van de gevolgen van aanpassingen in waterbeheer voor habitats. De kaarten geven een statische situatie weer. Vragen over de kwaliteit van deze natuur zoals morfologische veranderingen in de tijd, gevolgen voor soorten etc. zijn bediscussieerd op basis van expert oordeel en bestaande literatuur. Nu zal deze opzet van de PBL studie aangepast en toegepast worden met focus op het Grevelingenmeer.

Aansluitend nam Arno Nolte het woord en introduceerde "Good modelling practice", die zorgen voor transparante, reproduceerbare en wederzijds begrepen modelresultaten. Er kunnen drie fases worden onderscheiden, waarin belangrijke aspecten moeten worden uitgelegd en met de betrouwbaarheid van modelinformatie goed moet wordt omgegaan:

1. Probleemdefinitie en modelkeuze - fase 1

2. Kalibratie en validatie - fase 2

3. Scenario-fase 3 
Voordat de modellering begint moet de probleemeigenaar en modelleur het eens worden over wat het probleem is en wat men met een model verwacht te bereiken. De vertaling van de vraag naar bruikbare en modelleerbare indicatoren staat centraal. Tijdens en na de modellering is regelmatige toetsing tussen de modelleur en de probleemeigenaar belangrijk, zodat desondanks kennisleemtes de modelresultaten goed te vertalen zijn in de oorspronkelijke vraag. Voor het Grevelingenmeer bijvoorbeeld, geldt dat er geen metingen zijn om het effect van $50 \mathrm{~cm}$ getijslag te kunnen valideren. Daarom moet men beginnen met een conceptueel model, waar wiskundige formuleringen worden gebruikt om oorzaak effect relaties te begrijpen in plaats van metingen uit te voeren. De uitwisseling van water door toelaten van getij kan bijvoorbeeld uitwerken op stroming, belasting met stoffen uit het sediment, connectiviteit van soorten etc. Daarna moet er gezamenlijk een beslissing komen, welke van de verwachte effecten in het model moeten worden meegenomen. Verder legden Jeroen en Arno met voorbeelden uit wat voor modellen er klaarliggen voor de studie: 0 , 1, en 3D modellen.

De habitat analyse van het gehele delta (PBL studie) is gebaseerd op 99 segmenten, met het 1D model als basis. Er werden de huidige situatie en 7 scenario's (waaronder zeer extreme) gemodelleerd. De resultaten (incl. habitat kaarten) van "variant 3" (toelaten van $50 \mathrm{~cm}$ getijslag) van de PBL studie specifiek voor het Grevelingenmeer kunnen een eerste indicatie geven.

Interessant voor de scenariostudie:

- Vanuit de habitat kaart kijken naar oppervlaktes en voorkomen van habitats.

- Stuurknoppen voor het definiëren van scenario's:

- Getijslag

- Peil

- Verbindingen met andere bekkens

- Aanhaken op de ontwerp RSV

- Deze meeting: focus op winst voor de natuur

Commentaren/ Antwoorden zuurstofproblematiek/ getijslag:

- Welke invloed wordt verwacht met $50 \mathrm{~cm}$ getij op het Grevelingenmeer?

- Erosie intergetijdengebied neemt langzaam af.

- Oppervlakte droge (terrestrische) habitats neemt af.

- Zuurstofhuishouding verbetert.

- Nutriëntenconcentraties (bv. N) verhoogt licht; daardoor gaat ook de primaire productie omhoog.

- In "minder zomerse zomers" (d.w.z. koud, winderig) is de zuurstofhuishouding minder problematisch. Is het mogelijk om in dit soort omstandigheden tijdelijk minder getijslag toe te laten (door de kokers minder open te zetten)?

- Echter moet men opletten, want zuurstoflosheid kan binnen ca. 3 weken ontstaan. Maar zodra er zuurstofloosheid is ontstaan, kan het lang duren om het systeem weer te herstellen.

- Voorstel/idee om lerend te implementeren: Bv in stappen, eerst naar $30 \mathrm{~cm}$ getijslag gaan en meten of dit al voldoende is.

- Lerend implementeren: ja.

- Maar: Hoe gaat dat zodra er een besluit is om echt (een getijdecentrale) te bouwen?

- $30 \mathrm{~cm}$ getijslag zal de zuurstof problematiek niet helemaal oplossen. Het ene jaar wel, maar het ander jaar niet. Daarom is het advies om niet aan het randje te gaan zitten.

- Vergelijking met Haringvliet: Getijslag daar was toen vooral aan de onderzijde, waarschijnlijk omdat Haringvliet peil nu hoger staat dan NAP.

- $\quad$ Fijn-afregeling is belangrijk, b.v. bij vloed knijpen, d.w.z. 2 of 3 kokers dicht zetten.

- Vraag over het halen van het minimum peil-level ( $-45 \mathrm{~cm}$ NAP): Het minimum level wordt vaak niet bereikt. Is dat niet een enorme beperking voor de getijdencentrale? Volgens Paul is dat probleem inmiddels minder groot door innovatie bij de turbines. Het gaan om de gemiddelde getijslag.

Commentaren/ Antwoorden habitat modellering:

- Naar aanleiding van de presentatie van de habitats, die in de PBL studie zijn gebruikt: Zoete schorren zouden moeten worden herbenoemd in "grienden".

- Goed uitwerken wat de verandering van habitats voor bepaalde soorten betekend. 
- (Gert Jan:) NIOZ commentaar (Filip Meysman) over slib effect in Grevelingenmeer dat door getij vrij zou komen. Anorganisch slib is niet in het 3D model meegenomen. Organische deeltjes zijn wel meegenomen. Naar aanleiding van de zienswijze van het NIOZ waarin de mogelijke slibproblematiek is aangekaart, heeft aanvullend onderzoek plaatsgevonden, bestaande uit monstername en analyse van sediment en een expertsessie met diverse deskundigen. Hier kwam uit dat het risico op vertroebeling niet waarschijnlijk wordt geacht. Een openstaande vraag is of de slibhuishouding een effect heeft op de zuurstofhuishouding. Dit onderzoek loopt nog.

- Belangrijk om ook beheersmaatregelen mee te nemen.

\section{Discussie: welke scenario's onderzoeken?}

De discussie wordt gevoerd in twee werkgroepen. Belangrijke stuurknoppen zijn: (variatie in) getijslag, middenpeil en evt. een verbinding met andere bekkens.

\section{Werkgroep A: Optimalisatie RSV}

Eerst werd gediscussieerd over de feitelijke speelruimte die mogelijk is binnen de RSV waarbij het volgende werd besproken:

- Getijslag van $50 \mathrm{~cm}$ is leidend voor de waterkwaliteit op basis van wat in voorgaande jaren is onderzocht. Is een kleinere getijslag mogelijk? Dit wordt niet helemaal duidelijk.

- Het middenpeil is wel vastgelegd, maar niet eventuele seizoenfluctuatie. De vraag wordt gesteld of een middenpeil van $-30 \mathrm{~cm}$ NAP bv tijdens het broedseizoen wel kan.

- Keuze: al dan niet toelaten van springtij $(+/-5 \mathrm{~cm})$

- Inrichtingsmaatregelen (bv aanleg broedvogel eilandjes) en beheer wordt ook als een belangrijke stuurknop gezien. Dit kan niet meegenomen worden in de modelstudie maar kan wel bediscussieerd worden.

Vragen/aandachtspunten:

- Het blijft een geknutseld systeem en gericht beheer en compenserende maatregelen zullen ook in de toekomst nodig zijn om natuurwaarden te behouden/beschermen

- Gevolgen primaire productie door verbinding met de Noordzee? Vooral in het westelijk deel van het meer? Of ook in het oosten? Veerse Meer als voorbeeld nemen. Wat zijn de effecten van nutriënten en wat betekent dit voor doorzicht? En hoe werkt dat door op soorten -> bodemleven, vissen en visetende vogels, steltlopers?

- Wat wordt de kwaliteit van de nieuwe intergetijdengebieden? De zorg is dat ze zandig zullen zijn waardoor er maar beperkt bodemleven ontwikkelt en dus beperkt voedselaanbod voor vogels.

- Wat is de rol van opstuwing? Wind opzet?

- Relatie van de habitats in het Grevelingenmeer in relatie beschouwen met de gehele delta

- Hoe loopt de ontwikkeling van intergetijdenhabitats? Zandhonger problematiek etc.

- Begin bv met lager middenpeil om zandhonger probleem te voorkomen.

- Wat zijn effecten op grondwater? Dit is complex en hier is nog maar weinig over bekend en onderzoek naar gedaan.

Voorgestelde scenario's in deze werkgroep:

$\begin{array}{llll}\text { Scenario } & \text { "RSV" } & \text { "RSV-30" } & \text { "Peilbeheer" } \\ \text { Getijslag } & 50 \mathrm{~cm} & 30 \mathrm{~cm} & 50 \mathrm{~cm} \\ \text { Peil } & -20 \mathrm{~cm} \text { NAP } & -20 \mathrm{~cm} \text { NAP } & -20 \mathrm{~cm} \text { NAP (winter) } \\ & & & -30 \mathrm{~cm} \text { NAP (zomer) }\end{array}$

\section{Werkgroep B: Lange termijn}

De discussie focuste meteen op de lange termijn en met name op de effecten van zeespiegelstijging. Zeespiegelstijging heeft op de lange termijn veel invloed op de scenario's. Refererend naar de presentatie van Paul werd er meteen geconcludeerd dat alle bouwkundige veranderingen pas in 2023 op zijn vroegst gaan beginnen, voor ca. 30 jaar. Aan het eind van deze periode (rond 2050) zouden de plannen voor het gehele delta sowieso opnieuw moeten worden geëvalueerd. Zeespiegelstijging zal hier een belangrijke rol spelen. We moeten voorkomen dat we met keuzes van nu geen spijt over 30 jaar hebben. 
Wat zijn de functies waar we naar kijken?

- onderwater systemen

- vochtige duinvalleien, duinvalleivegetatie

- inter-getijdegebieden

- $\quad$ kustvogels/ broedvogels

De volgende ideeën voor scenario studies/ onderzoek zijn besproken:

- Middenpeil verlagen om zo over 30 jaar in verband met zeespiegelstijging het peilniveau gelijkmatig te kunnen verhogen, en om afslag te beperken. Echter leidt dit nog steeds tot een probleem met zeespiegelstijging op lange termijn.

- Kan dat leiden tot opslibbing?

- $\quad$ Extra sediment injecties? Eilandjes bouwen in het GM?

- Goed nadenken over de rol van slib.

- Oplossing voor Zandhonger - om niet natuur kwijt te raken.

- Importeren vanuit voordelta

- Via VZM?

- Intern uit het GM halen?

- Focus op de droogvallende natuur (getijdengebieden, droogvallende zandplaten, slikken) met broedvogels en duinvalleivegetatie. Vochtige duinvalleien: Het is de vraag of deze in de toekomst, rekening houdend met de zeespiegelstijging, überhaupt gehandhaafd kunnen worden in het GM. Wellicht kan er gekeken worden naar andere gebieden (Noordzeekust). NB: De functie 'Vochtige duinvalleien' is waarschijnlijk over 30 jaar niet meer realiseerbaar in het Grevelingenmeer vanwege zeespiegelstijging.

- Welke soorten zitten er nu?

- Hoe groot is dit habitat in het GM in verhouding met de rest van dit habitat in NL? Men constateerde dat dit areaal in de OS, WS en ED afneemt (Gebruik de Natura 2000 structuur van habitats en natuurwaardes).

- Slim erover nadenken, waar NL welke habitats wil hebben, ook over de lange termijn.

- $\quad$ Niet vergeten dat vochtige duinvalleien op zoet water gebaseerd zijn.

- Scenario Estuarien systeem: Hoe kan het natuurlijker? Wat zijn de tussenstappen?

- Doorlaat alleen sluiten tijdens stormen?

Er is niet gesproken over scenario's met verbinding naar het VZM.

$\mathrm{Er}$ is geconcludeerd dat er lokaal veel kan worden opgelost door "lokale Spielereien", als het alleen gaat om het halen van juridische doelstellingen, maar alleen op kleine schaal. Bv. het aanleggen van schelpenbanken om afslag lokaal te voorkomen. Dit is echter geen oplossing voor de lange termijn.

Voorgestelde scenario ideeën in deze werkgroep:

$\begin{array}{llll}\text { Scenario } & \text { Zeespiegelstijging } & \text { Estuarien } & \text { Zandimport } \\ \text { Getijslag } & 50 \mathrm{~cm} & \text { open } & \text { Berekenen } \\ \text { Peil } & -20 \mathrm{~cm} \text { NAP } & \text { open } & \text { Berekenen } \\ \text { Verbinding } & & \text { open } & \text { VZM ? } \\ \text { Focus op } & - \text { Zeespiegelstijging } & \text { Sluiten alleen } & \text { Focus op sedimentatie/ } \\ & - \text { Opslibbing/ zand } & \text { tijdens stormen } & \text { import van sediment uit } \\ & \text { injecties } & & \text { VZM of GM. Dan de } \\ & & & \text { optimale stuurvariabelen } \\ & & & \text { berekenen. }\end{array}$

\section{Vervolg}

- Rest van 2016: uitwerken ecologische onderbouwing en scenario's (zie document "Opzet scenariostudie_FINAL.docx"); beschrijven aanpak modelstudie

- 2017: modelstudie WMR/Deltares, ontwikkelen habitatkaarten en bediscussiëren van de resultaten.

- Terugkoppeling van de modelstudie resultaten aan stakeholders in 2017 


\section{Verslag overleg tussentijdse terugmelding met natuurpartijen en beheerders}

BIJEENKOMST

AANWEZIG

Scenariostudie Grevelingenmeer eerste resultaten

AFWEZIG

LoCATIE

KOPIE AAN

Rotterdam

DATUM EN TIJD

Donderdag 26 oktober 2017, 13:00-16:00

\section{Aanwezig:}

\section{Naam}

Alphons van Winden

Bureau Stroming/WNF

Bernadette Botman

B2Consultancy

Arno Nolte

Deltares

Astrid Hilgers

Ministerie van Landbouw, Natuur en Voedselkwaliteit

Wendie Olivier

Ministerie van Landbouw, Natuur en Voedselkwaliteit

Krijn Tanis

Vereniging voor Natuur en Landschap Goeree Overflakkee

Cees de Kraker

Natuur en Vogelwacht Schouwen-Duiveland

Gert Jan Buth

Natuur en Vogelwacht Schouwen-Duiveland

John Beijersbergen

Natuur en Vogelwacht Schouwen-Duiveland

Marriet Berrevoets

Provincie Zeeland

Evert van der Meide

Provincie Zuid-Holland

Maarten Platteeuw

Rijkswaterstaat Water, Verkeer en Leefomgeving

Paul Paulus

Rijkswaterstaat Zee en Delta

Silvana Ciarelli

Rijkswaterstaat Zee en Delta

Carel Harmsen

Staatsbosbeheer

Christine Lammerts

Staatsbosbeheer

Inge Both

Vogelbescherming

Martijn Verweijen

Werkgroep Beter Zicht op de Grevelingen

Brenda Walles

Wageningen Marine Research

Jeroen Wijsman

Wageningen Marine Research

Marijn Tangelder

Wageningen Marine Research (verslaglegging)

\section{Terugmelding van de eerste resultaten}

Marijn Tangelder (WMR), Arno Nolte (Deltares) en Jeroen Wijsman (WMR)

Deze workshop is bedoeld om de tussentijdse resultaten van de scenariostudie met natuurpartijen en beheerders te delen en de gelegenheid te geven om input te geven. Doel van het onderzoek is om het natuurperspectief van het Grevelingenmeer in verschillende inrichtingsvarianten (scenario's) te onderzoeken. Dit onderzoek wordt uitgevoerd in opdracht van het ministerie van Landbouw, Natuur en Voedselkwaliteit (voormalig EZ) vanuit de Natuurambitie Grote Wateren. 
De scenario's die gemodelleerd zijn staan in de onderstaande tabel weergegeven:

\begin{tabular}{|c|c|c|c|c|c|c|}
\hline Scenario & $\begin{array}{l}1 . \\
\text { Huidige } \\
\text { situatie }\end{array}$ & $\begin{array}{c}2 . \\
\text { RSV }\end{array}$ & $\begin{array}{l}3 . \\
\text { RSV- } \\
\text { springtij }\end{array}$ & $\begin{array}{l}4 . \\
\text { RSV-30 }\end{array}$ & $\begin{array}{l}5 . \\
\text { RSV- } \\
\text { Peilbeheer }\end{array}$ & $\begin{array}{l}6 . \\
\text { Zeespiegel- } \\
\text { Stijging } 2050\end{array}$ \\
\hline Getijslag [m] & Microgetij & 0,50 & 0,50 & 0,30 & 0,50 & 0,50 \\
\hline Peil [m NAP] & $\begin{array}{l}-0,20 \\
\left(" \text { winter" }{ }^{\prime \prime}\right) \\
-0,26 \\
\left(" z o m e r^{\prime \prime}\right)\end{array}$ & $-0,20$ & $-0,20$ & $-0,20$ & $\begin{array}{l}+0,10 \\
(" w i n t e r ") \\
-0,26 \\
(" z o m e r ")\end{array}$ & $+0,20$ \\
\hline $\begin{array}{l}\text { Springtij/ } \\
\text { doodtij cyclus } \\
\text { [m] }\end{array}$ & 0 & 0 & $+/-0,05^{7}$ & 0 & 0 & 0 \\
\hline
\end{tabular}

Deze scenario's zijn uitgewerkt in een modelstudie door Deltares. Hiervoor is gebruik gemaakt van zowel een OD-model (opstellen waterbalans en afregeling getijslag) als het 3D model dat inzicht geeft in de gemodelleerde waterstanden, zuurstofhuishouding, waterbeweging, waterkwaliteit en primaire productie per scenario in het Grevelingenmeer. Hierin is gemodelleerd met drie doorlaten, Brouwerssluis, Flakkeese Spuisluis en een doorlaat in het noordelijk deel van de Brouwersdam. Uitgaande van het referentieontwerp van deze doorlaat waarin 15 kokers van $8 \mathrm{mx} 8 \mathrm{~m}$ zijn voorzien, zijn er in totaal dus 17 knoppen waarmee in principe nauwkeurige fijnafregeling van het waterbeheer kan plaatsvinden (dit zit nu niet in het model waarbij met één doorlaat is gemodelleerd i.p.v. 15 kokers). Ook laat het model zien dat de waterstandsfluctuaties als gevolg van getij in de zomer regelmatiger zijn dan in de winter. Dit komt door de invloed van wind en stormen in de winter die zorgen voor tijdelijke opzet of verlaging van de waterstand.

Door WMR zijn getijstatistieken (GHWS, GHWD, GLWS, GLWD, etc.) berekend voor 27 locaties in het Grevelingenmeer op basis van de door Deltares met het 3D model berekende waterstanden. Deze begrenzingen zijn gebaseerd op het ZES ecotopenstelsel voor de zoute wateren (Bouma et al. 2005). De getijstatistieken zijn vervolgens geïnterpoleerd over het hele meer en geprojecteerd op de dieptekaart die informatie geeft over welke delen droog, droogvallend en nat zijn. De volgende ecotopen worden onderscheiden:

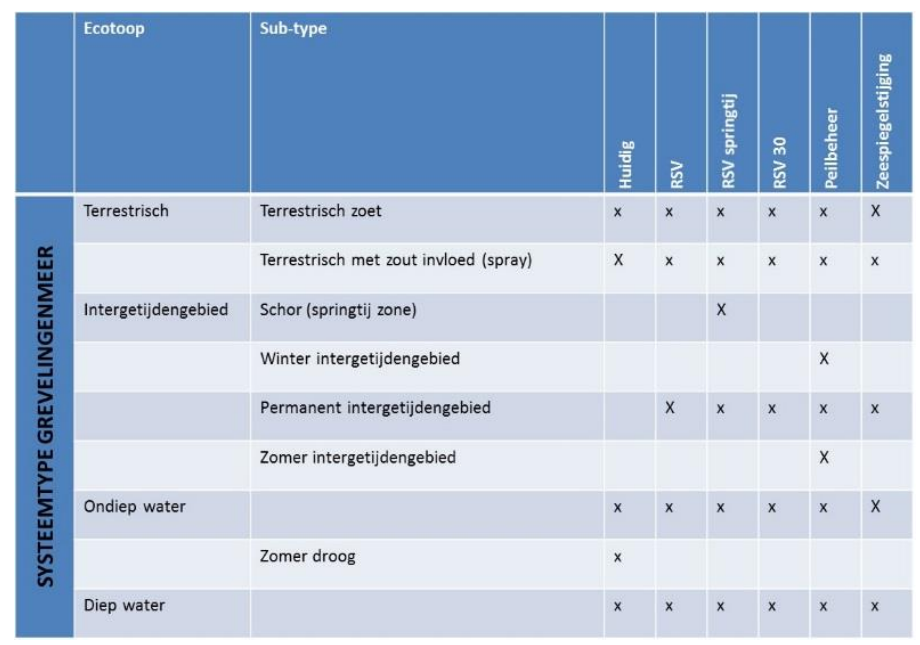

De 'droge' ecotopen zijn opgesplitst in 'terrestrisch zoet' en 'terrestrisch zout'. Het ecotoop terrestrisch zout vertegenwoordigt de begroeiing die onder zoutinvloed staat door spray en verstuiving en incidentele opzet door wind. Deze invloed verschilt lokaal en is afhankelijk van verschillende factoren zoals windrichting, verloop van de oever etc. Om de breedte van de 'zone van zoutinvloed' te kunnen

\footnotetext{
${ }^{5}$ Het middenpeil wordt zoveel mogelijk gehouden op NAP -0,20 m (fluctuerend tussen max. -0,10 NAP en min. NAP -0,30 m; in de periode sep-feb wordt in drie perioden van drie weken gestuurd op een middenpeil van NAP -0,16 m.

${ }^{6}$ Tijdens broedseizoen (1 april -15 juli) wordt gestuurd op een middenpeil van NAP $-0,26 \mathrm{~m}$.

${ }^{7}$ Toelaten getijfluctuatie volledige springtij-doodtij cyclus
} 
onderbouwen is gebruik gemaakt van gegevens van Bureau Waardenburg (Van de Haterd et al. 2010). Intergetijdengebied wordt onderverdeeld in sub-ecotopen schor (de zone tussen Gemiddeld Hoog Water Springtij en Gemiddeld Hoog Water Doodtij), permanent intergetijdengebied en winter/zomer intergetijdengebied (afhankelijk van peilbeheer). Naast de ecotopen 'ondiep water' en 'diep water' is ook een ecotoop 'zomer droog' benoemd die de zone aangeeft die in de zomer droogvalt en in de winter ondiep water vormt als gevolg van peilbeheer in de huidige situatie.

De eerste resultaten laten zien dat, zoals verwacht, in een situatie met getij een verschuiving plaatsvindt van terrestrisch ecotoop (zoet/zout) naar intergetijdengebied en ondiep water. In de scenario's met 50 $\mathrm{cm}$ getij is dit effect logischerwijs sterker dan bij $30 \mathrm{~cm}$ getij. In scenario RSV-springtij wordt een getij van $50 \mathrm{~cm}$ en een springtij-doodtij zone van $10 \mathrm{~cm}$ geprojecteerd die wordt benoemd als schor ecotoop en ten koste gaat van zoute vegetatie. Hier zal zich naar verwachting geen volwaardig schor en geulenstelsel ontwikkelen want daarvoor is de zone te smal, maar mogelijk wel zilte pionier schorsoorten. De scenario's Peilbeheer en Zeespiegelstijging zorgen naar verhouding voor een grote verschuiving van terrestrisch ecotoop naar intergetijdengebied en ondiep water.

Werkgroepen: input vanuit natuurpartijen en beheerders

In twee werkgroepen worden de resultaten tot nu toe besproken. Hieronder staat samengevat wat besproken en ingebracht is door de aanwezigen.

Algemeen:

- De ecotopenkaarten laten een 'star' beeld zien met harde grenzen die in de realiteit veel meer fluctuatie en variatie laten zien. Ook zeggen de ecotopen niets over de kwaliteit van natuurwaarden. De interpretatie van de kwaliteit van de ecotopen in de scenario's is nog een belangrijke stap die gemaakt moet worden.

- Introductie van getij zal ten koste gaan van de laaggelegen vochtige duinvallei vegetaties die voornamelijk op de eilanden voorkomen. Dit vegetatietype zal naar verwachting niet opschuiven naar hoger gelegen delen. Het biedt voordelen voor de 'natte' ecotopen en kansen voor voedselvoorziening van steltlopers. Het biedt voordelen voor de 'natte' ecotopen vanwege o.a. de reductie van zuurstofloosheid en de toename van het areaal intergetijdengebied biedt kansen voor voedselvoorziening van steltlopers.

- De vegetatietypen op de Slikken van Flakkee kunnen wel opschuiven. Belangrijke kanttekening is dat het voorkomen van vegetatietypen van (veel) meer factoren afhankelijk is dan alleen waterstanden. Denk bijvoorbeeld aan de opbouw van de ondergrond (zand, klei, veen), voedingsstoffen in de bodem en de mate waarin zich de afgelopen decennia bodemvormende processen hebben voorgedaan etc.

- De zones van zilte vegetaties in de ecotopenkaarten in de huidige situatie zijn niet overal in overeenstemming met de werkelijkheid. WMR zoekt nog naar mogelijkheden om dit te verbeteren en staat open voor suggesties.

- Gerichte beheersmaatregelen zullen ook in de toekomst nodig blijven om terrestrische natuurwaarden te waarborgen.

- $\quad$ Bij zware en langdurige regenval in de winter kunnen de eilanden zeer nat worden. Dit gebeurt nu ook al en zal vanwege de humusvorming in de bodem ook autonoom verder toenemen. Peilverhoging (bv. als dit noodzakelijk wordt door zeespiegelstijging) kan er toe leiden dat water niet meer weg kan en er ontstaat een 'zwembad'. Dit speelt vooral op de Veermansplaat. Hierdoor wordt het te nat voor aanwezige bijzondere vegetaties.

\section{RSV, RSV Springtij en RSV 30}

- De zone van zilte vegetaties zal met introductie van getij opschuiven naar hogere delen ten koste van zoetminnende vegetaties. Het zal een tijd duren (tot mogelijk decennia) voordat deze delen volledig verzilt en ontwikkeld zijn tot een zilt vegetatietype. De tijdsduur van aanpassing en ontwikkeling is overigens niet goed bekend. Diersoorten als bodemdieren, vogels en vissen kunnen zich waarschijnlijk veel sneller aanpassen aan een nieuwe situatie met getijslag.

- $\quad$ Met introductie van getij zal huidig broedvogel habitat van de broedvogels van het zilte gebied en net daarboven overspoelen.

- Voor terrestrische (zoet/zout) ecotopen en broed habitat is een beperktere getijslag zoals in het scenario RSV 30 te prefereren boven een getijslag van $50 \mathrm{~cm}$. Kustbroedvogels zijn niet gebaat 
bij de introductie van getij, maar wel bij optimalisatie van het peilbeheer. Daarmee kan dan vegetatiesuccessie worden tegengegaan en kale delen te creëren voor broeders van kale gronden. Dit gebeurt nu al, maar kan nog beter. Daarbij is een kale vlakte alleen niet voldoende maar zijn schelpenbanken, zandbanken gewenst om vestiging van broedvogels te stimuleren.

- Waarde van het nieuwe intergetijdengebied als foerageergebied: de verwachting wordt aangegeven dat het bodemleven van beperkte waarde zal zijn, omdat aanbod van voedsel beperkt is. Ook het zandige bodemmateriaal zou minder gunstig voor bodemleven zijn.

\section{RSV Peilbeheer}

- In dit scenario is gekozen voor een flinke peilopzet in de winter tot $+10 \mathrm{~cm}$ NAP om onderscheidend te zijn met andere scenario's. Benadrukt wordt dat het voor terrestrische natuurwaarden wenselijk is om te kiezen voor een geringer peilverschil van bijvoorbeeld $-30 \mathrm{~cm}$ NAP in de zomer en $-20 \mathrm{~cm}$ NAP in de winter. Hier liggen mogelijkheden voor optimalisatie. Peilbeheer is belangrijk voor broedvogels en beheer is gewenst om geschikt habitat te krijgen (zie eerder). De komst van de vos is ook een belangrijk aandachtspunt. Dit maakt broedvogelhabitat omsloten door water van extra belang voor de broedsuccessen. Eventueel aanleggen van broedeilanden als beheersmaatregel. Tevens is voor veel vogels de combinatie van broedhabitat en foerageerhabitat van belang.

- $\quad$ Peilopzet in de nazomer is van belang om de afplatting van de zoetwaterbel tegen te gaan. Dit kan ten koste gaan van vochtige duinvalleivegetaties.

- Ook dit scenario gaat ten koste van vegetatie (zout/zoet) en zal de grondwaterstanden beïnvloeden.

- Hoewel er in dit scenario veel areaal intergetijdengebied ontstaat worden vraagtekens geplaatst bij de ecologische waarde van deze gebieden vanwege het alternerend peilbeheer. Bodemleven zal maar beperkt kunnen ontwikkelen en in de zomerperiode weer sterven vanwege het niet meer overstromen en daardoor ook maar beperkter van betekenis zijn als foerageergebied. In de winter zou dit ook nadelig kunnen zijn voor overtijende vogels die op zoek zijn naar een hoogwater vluchtplaats.

- Ondiep water habitat is waardevol voor juveniele vis die weer een voedselbron vormen voor grotere vissen en vogels.

\section{RSV Zeespiegelstijging}

- $\quad$ Dit scenario laat de situatie bij maximale zeespiegelstijging in 2050 zien $(+40 \mathrm{~cm})$. Het lijkt nog ver weg maar het komt dichterbij en we kunnen er niet om heen.

- Overheden zouden meer aandacht moeten hebben voor de discussie over hoe hiermee om te gaan. Compenseren? Mitigeren? Doelen aanpassen? Wat zijn realistische keuzes.

- $\quad$ Ook is de verwachting dat met de opwarming van de aarde soorten gaan verschuiven. Ook hier moeten we rekening mee houden. Hoe gaan we hier mee om?

- Het is goed om te realiseren dat het peil op de Grevelingen mee groeit met de zeespiegelstijging, hetgeen ten koste zal gaan van de zoete vegetaties. De nieuwe doorlaat biedt in dat licht juist ook kansen om de zeespiegelstijging op te vangen en het middenpeil langer laag te houden. Zo kunnen huidige terrestrische natuurwaarden op de oevers en eilanden zo lang mogelijk behouden blijven.

- Toename aan ondiep water ecotoop biedt kansen voor voedsel voor vissen en daarmee ook weer voor zeezoogdieren en vogels.

\section{Vragen/acties}

Hieronder staan de vragen op een rijtje die aan WMR gesteld. Achter iedere vraag staat aangegeven hoe hiermee omgegaan zal worden:

- Breng, zo goed als mogelijk, de winst en verlies van natuurwaarden in beeld (expertsessie/uitwerking)

- Het areaal intergetijdengebied zal toenemen. Een belangrijke vraag is waarde van deze intergetijdengebieden voor foeragerende vogels. Zal zich hier een voldoende rijk bodemleven ontwikkelen die het intergetijdengebied waardevol maakt als foerageer habitat? (expertsessie)

- Een grote onzekerheid in dit onderzoek is het bodemprofiel tussen -0,20 en -1,5 meter NAP. Daardoor geven de ecotopenkaarten geen realistisch oppervlak van de intergetijdengebieden 
weer. Het is van belang het bodemprofiel in deze zone in kaart te brengen zodat arealen intergetijdengebied meer nauwkeurig kunnen worden berekend. (kennisvraag)

- Wat is de relatie tussen het terugdringen van zuurstofloosheid op de bodem door introductie van getij tot (her)ontwikkeling van het bodemleven in de diepe delen en betekenis hiervan voor het voedselweb (vissen en vogels)? (kennisvraag)

- Wat is de betekenis van de verbinding met de Noordzee en de introductie van getij voor de ontwikkeling van vis en visetende vogels en zeehonden? (expertsessie/kennisvraag)

- Het is wenselijk om de huidige habitattypekaart over de scenario's te projecteren zodat aangegeven kan worden hoeveel areaal verloren gaat en hoeveel potentieel nieuw habitat ontstaat (uitwerking).

- Hoe wordt de zoete grondwaterlens beïnvloed in de verschillende scenario's en wat zijn daar de consequenties van voor zoete vegetatietypen? (expertsessie)

- Wat is de positie van de spronglaag als gevolg van stratificatie en zuurstofloze delen nabij de bodem per scenario? (uitwerking)

- Wat is te verwachten van erosie en sedimentatieprocessen in de oeverzone in ieder scenario? Gaat er zandhonger optreden? (expertsessie)

\section{Ter afsluiting vanuit LNV}

Astrid Hilgers van het ministerie van LNV bedankte alle aanwezigen voor het deelnemen aan de workshop. Het ministerie van LNV vindt het van belang dat stakeholders betrokken worden en input kunnen leveren in het onderzoek.

\section{Vervolg}

- Expertsessies:

- Dinsdag 7 november, Yerseke: natuurwaarden oevers en eilanden

- Donderdag 16 november, Delft: natte natuurwaarden en onderliggende processen

- $\quad$ Rapportage gereed eind maart 2018

\section{Referenties}

Bouma, H., D. J. De jong, F. Twisk \& K. Wolfstein (2005). Zoute wateren EcotopenStelsel (ZES.1). Voor het in kaart brengen van het potentiële voorkomen van levensgemeenschappen in zoute en brakke rijkswateren. RIKZ, Middelburg. Rapport RIKZ/2005.024

Van de Haterd, R. J. W., W. Lengkeek, S. Bouma \& M. T. Collombon (2010). Herintroductie getij in de Grevelingen en effecten op natuur in intergetijdengebieden. Bureau Waardenburg:70 


\section{E. Beschrijving OD en 3D model}

\section{$\underline{\text { OD-model }}$}

Het OD-model is opgezet in Excel. Het berekent de waterstandsvariatie in het Grevelingenmeer, waarvan een constant wateroppervlak van 11.000 ha is aangenomen. In- en uitstroom van water vindt plaats via de Brouwerssluis, de Flakkeese spuisluis en de nieuwe doorlaat in de Brouwersdam. Het debiet door deze kunstwerken is afhankelijk van 1) het waterstandsverschil tussen Grevelingenmeer en Voordelta dan wel Oosterschelde, 2) het doorstroomoppervlak van het kunstwerk en 3) een weerstandscoëfficiënt van het kunstwerk. In het $0 D$-model wordt een eenvoudige relatie gebruikt tussen deze parameters.

$$
\begin{aligned}
& Q=A \times \varphi \times \sqrt{(2 \times g \times \Delta h)} \\
& \text { Met } \quad Q=\operatorname{Debiet}\left(\mathrm{m}^{3} / \mathrm{s}\right) \\
& A=\text { Doorstroomoppervlak }\left(\mathrm{m}^{2}\right) \\
& \Phi=\text { Weerstandscoëfficiënt }(-) \\
& \mathrm{g}=\text { Zwaartekrachtsversnelling }\left(\mathrm{m} / \mathrm{s}^{2}\right) \\
& \Delta \mathrm{h}=\text { Waterstandsverschil }(\mathrm{m})
\end{aligned}
$$

Onderstaande tabel geeft de aangenomen waarden voor doorstroomoppervlak en weerstandscoëfficiënt per kunstwerk. De gemeten waterstanden op locaties Brouwershavensche gat 08 en Krammersluizen West zijn gebruikt voor respectievelijk Voordelta en Oosterschelde (bron: waterinfo.rws.nl). Het ODmodel is opgezet voor de periode 1 november 2007 tot 31 december 2008, omdat het 3D model voor die periode beschikbaar is. Andere tijdseries van gemeten waterstanden kunnen echter eenvoudig worden toegevoegd. Het is niet de verwachting dat de cumulatieve waterstandsvariatie veel verschilt van jaar tot jaar.

\begin{tabular}{|l|l|l|}
\hline & Doorstroomoppervlak $\left(\mathrm{m}^{2}\right)$ & Weerstandscoëfficiënt $(-)$ \\
\hline Brouwerssluis & 90 & 0,85 \\
\hline Flakkeese spuisluis $^{1}$ & $\begin{array}{l}66,5 \text { Oosterschelde } \rightarrow \text { Grevelingenmeer } \\
60 \text { Grevelingenmeer } \rightarrow \text { Oosterschelde }\end{array}$ & 0,70 \\
\hline Doorlaat Brouwersdam ${ }^{2}$ & 960 (maximaal) & 0,85 \\
\hline
\end{tabular}

1 De waarden voor de Flakkeese spuisluis zijn afgeleid in Deltares (2016): Onderzoek zoetwaterlast Oosterschelde: modelstudie naar het effect van het innovatieve zoet-zout scheidingssysteem in de Krammersluizen op chlorideconcentraties in de Oosterschelde; auteurs W.M. Kranenburg, M.R. Schueder, D.J. Vreeken, T. van der Kaaij en O.M. Weiler, Rapport 1221409, in opdracht van Rijkswaterstaat, juni 2016.

${ }^{2}$ Het basisontwerp van de doorlaat in de Brouwersdam bestaat uit 15 kokers van $8 \mathrm{~m}$ bij $8 \mathrm{~m}$

Tenslotte bevat het OD-model twee faciliteiten om scenario's door te rekenen. Alleen deze parameters worden gewijzigd tussen de verschillende scenario's:

A. De waterstand in het Grevelingenmeer zal gestuurd worden tussen een maximale en een minimale waterstand. Deze worden opgegeven in het OD-model. Als de waterstand boven dan wel onder deze grens komt, worden alle kunstwerken dichtgezet.

B. Het is nog niet bekend hoe de nieuwe doorlaat in de Brouwersdam aangestuurd gaat worden. In theorie is het mogelijk ieder van de 15 kokers afzonderlijk te openen en te sluiten. Dat wordt in het OD-model gefaciliteerd door het doorstroomoppervlak afhankelijk te maken van de waterstand. Dat kan bovendien verschillend zijn tijdens de ebfase en de vloedfase.

Onderstaande screenshot laat het OD-model zien in Excel met in geel de parameters die als invoer dienen voor het model. 


\begin{tabular}{|c|c|c|c|c|c|c|c|c|c|c|c|}
\hline Algemene parameters & & & & & hmcz.nl & & & & & & \\
\hline Oppervlak Grevelingenmeer & \multicolumn{2}{|c|}{11000 ha } & & & Gemeten & Gemete & Berekend & Berekend & Berekend & Berekend & Berekend \\
\hline Brouwersdam & & & Datum & Flow time & $\begin{array}{l}\text { Bouwersha } \\
\text { vensche } \\
\text { gat } 08(\mathrm{~cm} \\
\text { NAP) }\end{array}$ & $\begin{array}{l}\text { Kramm } \\
\text { ersluiz } \\
\text { en } \\
\text { West }\end{array}$ & $\begin{array}{l}\text { Doorstroomopper } \\
\text { vlak Doorlaat } \\
\text { Brouwersdam }\end{array}$ & $\begin{array}{l}\text { Brouwersdam } \\
\text { Doorlaat } \\
\text { Debiet (m3/s) }\end{array}$ & $\begin{array}{l}\text { Brouwerssluis } \\
\text { Debiet (m3/s) }\end{array}$ & $\begin{array}{l}\text { Flakkeese } \\
\text { spuisluis } \\
\text { Debiet (m3/s) }\end{array}$ & $\begin{array}{l}\text { Waterstand } \\
\text { Grevelingenmeer } \\
\text { (cm NAP) }\end{array}$ \\
\hline Doorstroomoppervlak Brouwerssluis & \multicolumn{2}{|c|}{$90 \mathrm{~m} 2$} & $01-11-0700: 00$ & 437760 & -71 & -88 & 96 & -2581.22 & -241.99 & -153.41 & -20 \\
\hline Doorstroomoppervlak Doorlaat vloed & \multicolumn{2}{|c|}{$960 \mathrm{~m} 2$} & 01-11-07 00:10 & 437770 & -70 & -94 & 96 & -2513.95 & -235.68 & -158.27 & -21.62 \\
\hline Doorstroomoppervlak Doorlaat eb & \multicolumn{2}{|c|}{$960 \mathrm{~m} 2$} & 01-11-07 00:20 & 437780 & -69 & -98 & 96 & -2445.83 & -229.30 & -160.89 & -23.21 \\
\hline Afvoercoëfficiënt & \multicolumn{2}{|l|}{$0.85-$} & $01-11-0700: 30$ & 437790 & -68 & -103 & 96 & -2376.84 & -222.83 & -164.56 & -24.76 \\
\hline Bovengrens waterstand & \multicolumn{2}{|c|}{$10 \mathrm{~cm} \mathrm{NAP}$} & 01-11-07 00:40 & 437800 & -69 & -106 & 96 & -2362.84 & -221.52 & -166.12 & -26.26 \\
\hline Ondergrens waterstand & \multicolumn{2}{|c|}{$-50 \mathrm{~cm} \mathrm{NAP}$} & $01-11-0700: 50$ & 437810 & -68 & -108 & 96 & -2292.68 & -214.94 & -166.64 & -27.76 \\
\hline \multirow[t]{4}{*}{ Zeespiegelstijging } & \multicolumn{2}{|c|}{$0 \mathrm{~cm}$} & 01-11-07 01:00 & 437820 & -69 & -110 & 96 & -2279.57 & -213.71 & -167.20 & -29.22 \\
\hline & & & 01-11-07 01:10 & 437830 & -66 & -111 & 96 & -2148.24 & -201.40 & -166.73 & -30.67 \\
\hline & & & 01-11-07 01:20 & 437840 & -65 & -111 & 96 & -2074.85 & -194.52 & -165.30 & -32.05 \\
\hline & \multicolumn{2}{|c|}{ Doorstroomoppervlak } & 01-11-07 01:30 & 437850 & -64 & -112 & 96 & -2000.22 & -187.52 & -164.96 & -33.38 \\
\hline \multirow[t]{12}{*}{ Waterstand Grevelingenmeer (cm NAP) } & Vloed & & 01-11-07 01:40 & 437860 & -59 & -111 & 96 & -1783.26 & -167.18 & -162.55 & -34.66 \\
\hline & 0 & 0 & 01-11-07 01:50 & 437870 & -57 & -109 & 96 & -1663.78 & -155.98 & -159.16 & -35.81 \\
\hline & 640 & 192 & $01-11-0702: 00$ & 437880 & -56 & -106 & 96 & -1580.03 & -148.13 & -154.66 & -36.89 \\
\hline & 640 & 320 & 01-11-07 02:10 & 437890 & -53 & -101 & 96 & -1403.71 & -131.60 & -147.76 & -37.92 \\
\hline & 640 & 960 & $01-11-0702: 20$ & 437900 & -49 & -97 & 96 & -1152.35 & -108.03 & -141.88 & -38.84 \\
\hline & 640 & 960 & $01-11-0702: 30$ & 437910 & -46 & -89 & 96 & -914.37 & -85.72 & -130.76 & -39.60 \\
\hline & 640 & 960 & $01-11-0702: 40$ & 437920 & -43 & -81 & 32 & -200.99 & -56.53 & -118.81 & -40.22 \\
\hline & 320 & 960 & $01-11-0702: 50$ & 437930 & -39 & -72 & 64 & 287.38 & 40.41 & -104.54 & -40.42 \\
\hline & 0 & 960 & 01-11-07 03:00 & 437940 & -37 & -64 & 64 & 437.77 & 61.56 & -90.57 & -40.30 \\
\hline & 0 & 0 & 01-11-07 03:10 & 437950 & -35 & -58 & 64 & 542.97 & 76.36 & -78.76 & -40.08 \\
\hline & 0 & 0 & $01-11-0703: 20$ & 437960 & -29 & -52 & 64 & 791.25 & 111.27 & -65.03 & -39.78 \\
\hline & & & 01-11-07 03:30 & 437970 & -25 & -46 & 64 & 912.03 & 128.25 & -48.06 & -39.33 \\
\hline
\end{tabular}

Uit de berekende waterstand wordt de cumulatieve verdeling voor het hele jaar 2008 berekend en voor de maanden april tot en met september. Ook de cumulatieve verdeling van de hoogste en laagste waterstand per getij wordt berekend. Hieruit blijkt hoe vaak de toegestane maximale dan wel minimale waterstand wordt bereikt. Onderstaande figuren zijn een voorbeeld resultaat van bovenstaand scenario.

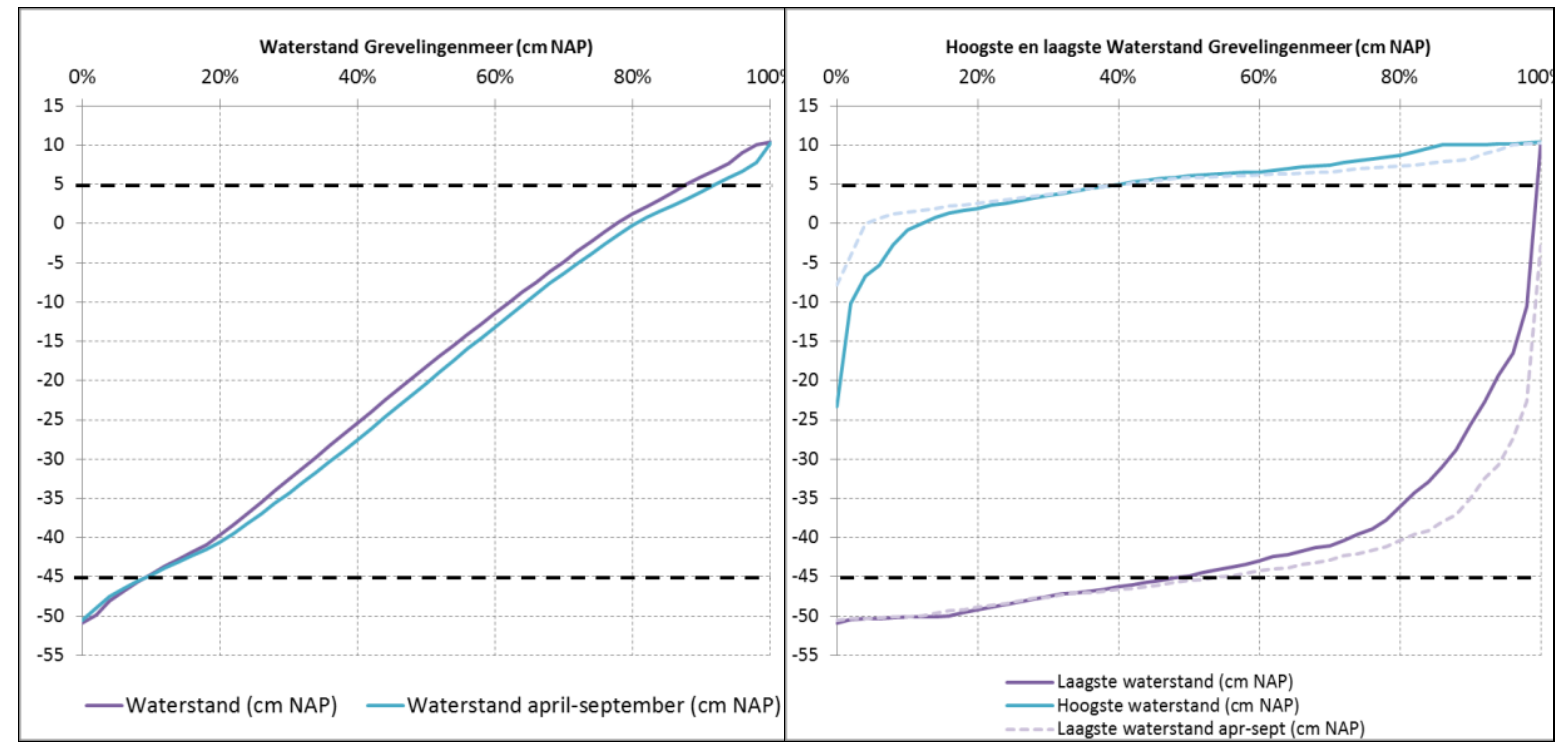

3D model voor waterbeweging, zuurstof, nutriënten en primaire productie.

Het 3D model is in diverse stappen ontwikkeld in opdracht van Rijkswaterstaat ten tijde van de MIRT Grevelingen in de periode 2008-2011. Het bestaat uit een Delft3D-FLOW model voor de waterbeweging, saliniteit en temperatuur en een DELWAQ model voor zuurstof, nutriënten en primaire productie. Deltares (2010) beschrijft de volledige modelopzet. Deltares $(2008,2011)$ beschrijft modelresultaten van eerdere scenariostudies. De modellen zijn gekalibreerd en gevalideerd met metingen uit 2000 en 2008. De situatie met getij is uiteraard niet met metingen te vergelijken, omdat het een niet bestaande, toekomstige situatie betreft.

Het model is uitgeleverd aan de Helpdesk Water

(https://www.helpdeskwater.nl/onderwerpen/applicaties-modellen/artikel/). 


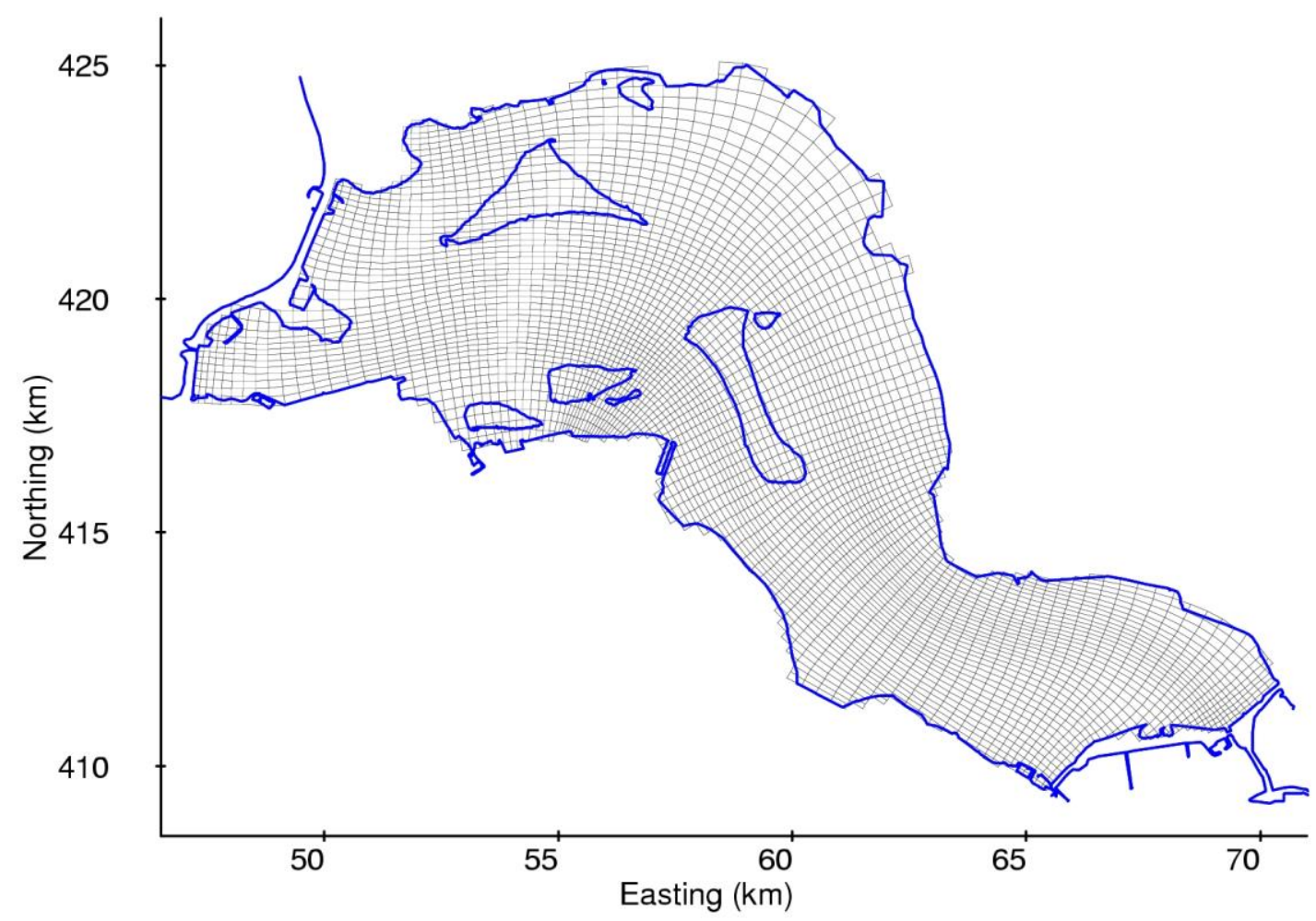

Het 3D Grevelingen model voor waterkwaliteit en primaire productie is een toepassing van DELWAQ. Een algemene beschrijving is bijvoorbeeld te vinden in Blauw, A. N., F. J. Los, M. Bokhorst and P. L. A. Erftemeijer (2009): GEM: a generic ecological model for estuaries and coastal waters, Journal Hydrobiologia, Pages 175-198, Issue Volume 618.

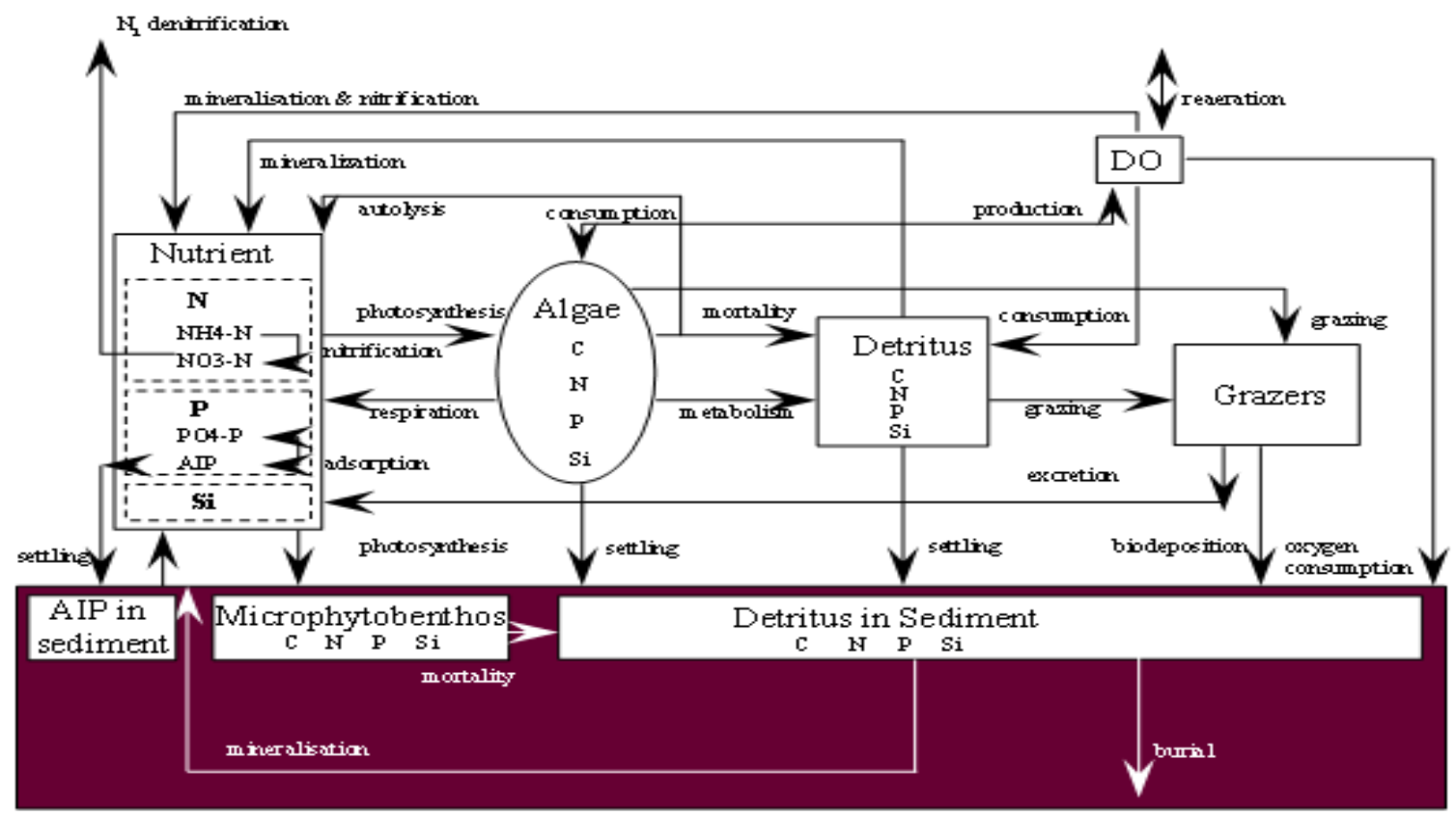

Schematisch overzicht van gemodelleerde stoffen en de belangrijkste (proces)fluxen

In DELWAQ worden (onder andere) de volgende processen gesimuleerd:

- fytoplankton processen: primaire productie, respiratie en mortaliteit

- $\quad$ extinctie van licht

- afbraak van organisch materiaal in water en sediment

- $\quad$ nitrificatie en denitrificatie

- re-aeratie

- $\quad$ sedimentatie en resuspensie

- begraving van organisch materiaal 


\section{F. Berekende waterstanden}

Waterstanden Scenario: Huidige situatie, Locatie: GTSO.01

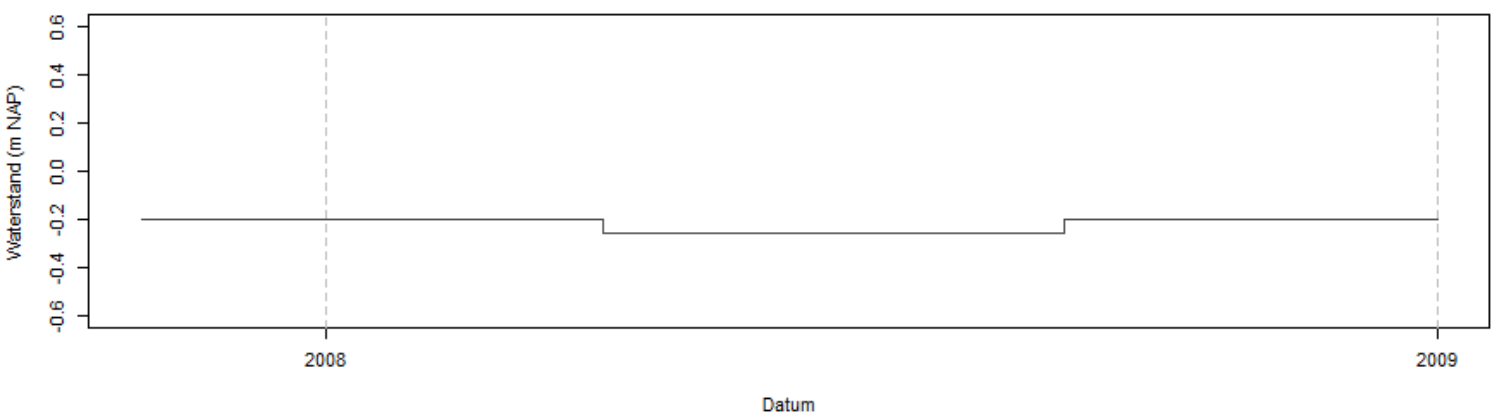

Waterstanden Scenario: Huidige situatie, Locatie: GTSO.12

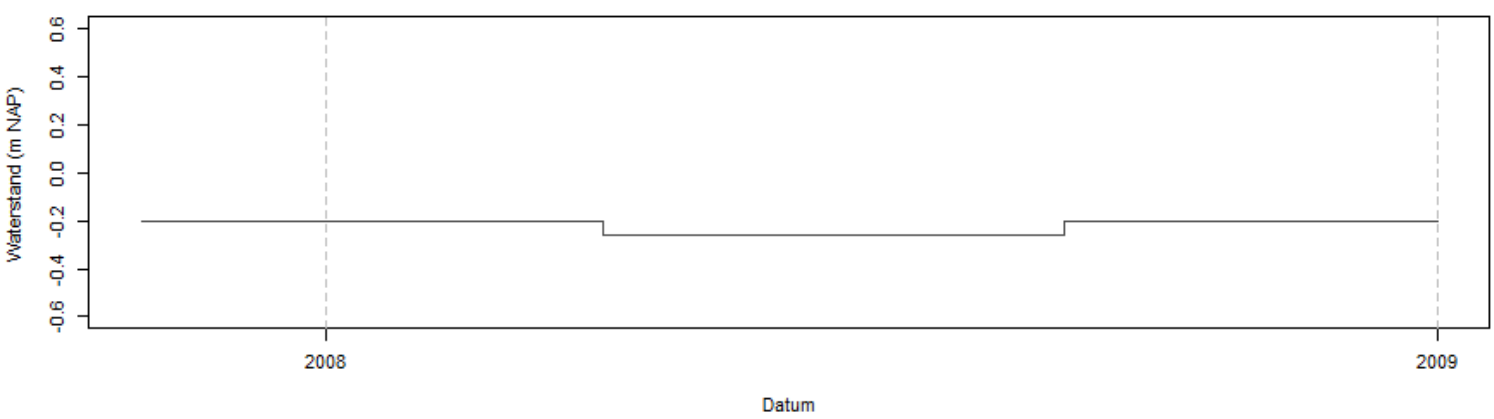

Waterstanden Scenario: Huidige situatie, Locatie: GTSO.20

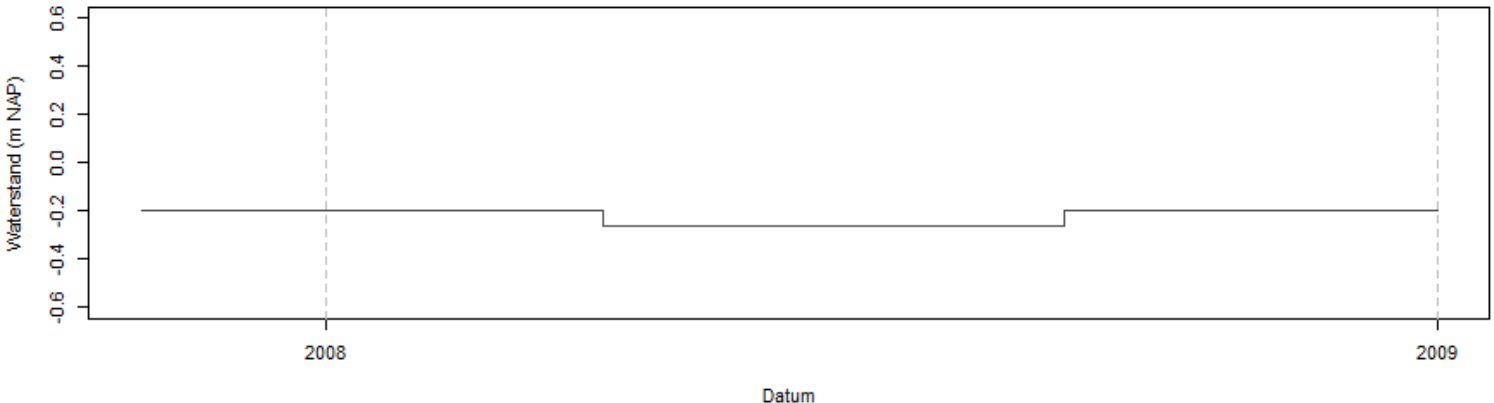

Figuur 21. Door het model berekende waterstanden voor het scenario 0 'Huidige situatie' op de locaties GTSO.01, GTSO.12 en GTSO.20. 
Waterstanden Scenario: RSV, Locatie: GTSO.01

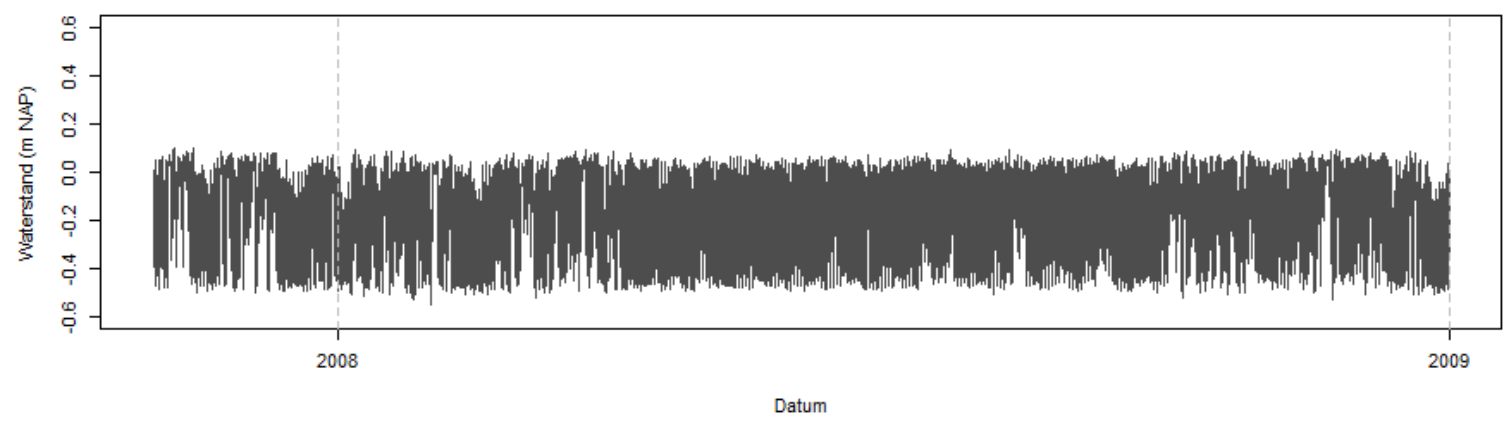

Waterstanden Scenario: RSV, Locatie: GTSO.12

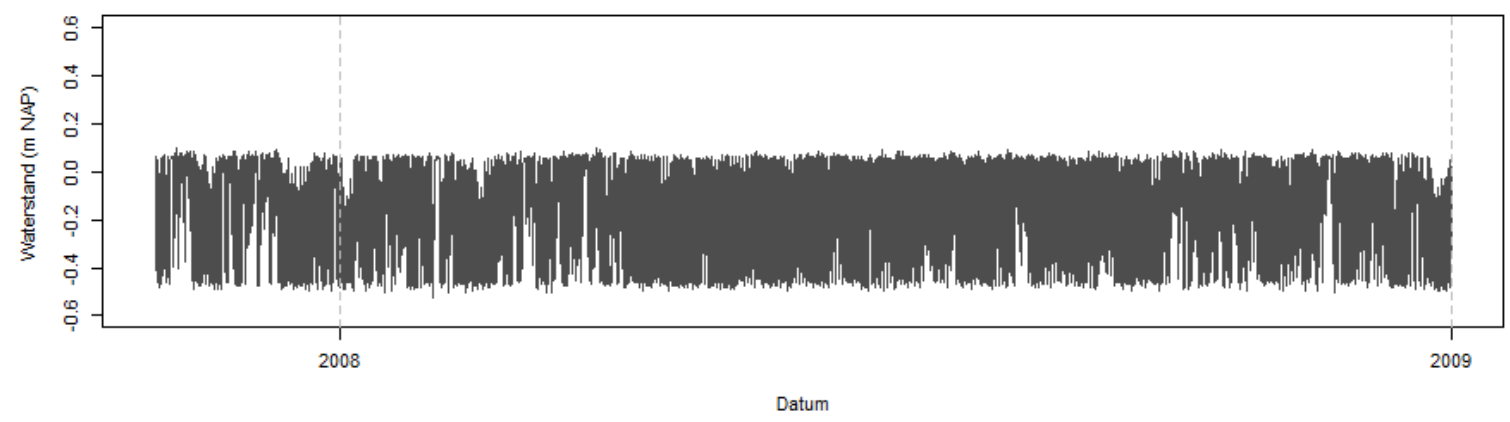

Waterstanden Scenario: RSV, Locatie: GTSO.20

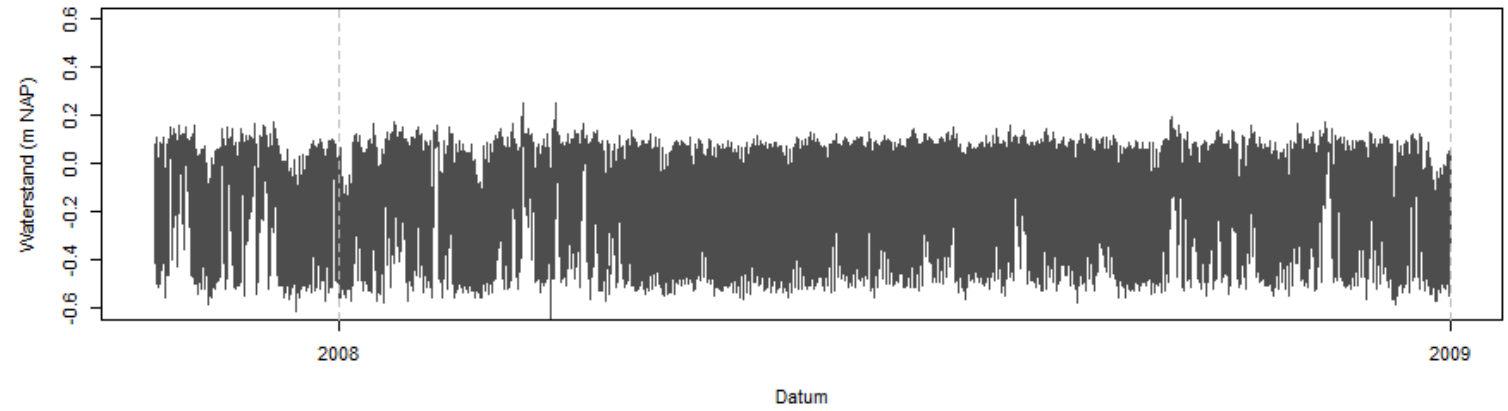

Figuur 22. Door het model berekende waterstanden voor het scenario 1 'RSV' op de locaties GTSO.01, GTSO.12 en GTSO.20. 
Waterstanden Scenario: RSV-Springtij, Locatie: GTSO.01

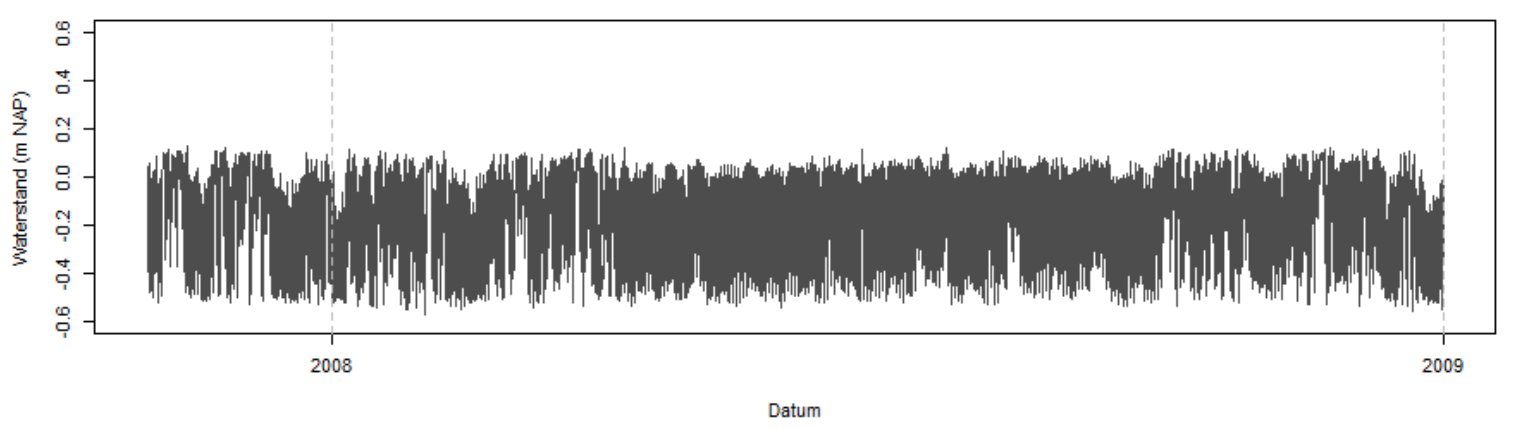

Waterstanden Scenario: RSV-Springtij, Locatie: GTSO.12

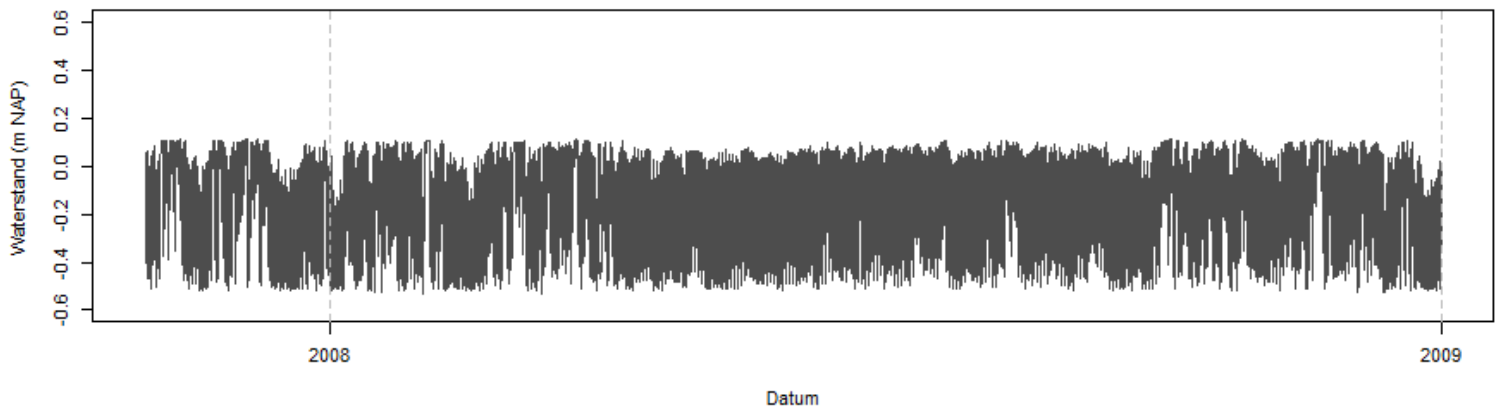

Waterstanden Scenario: RSV-Springtij, Locatie: GTSO.20

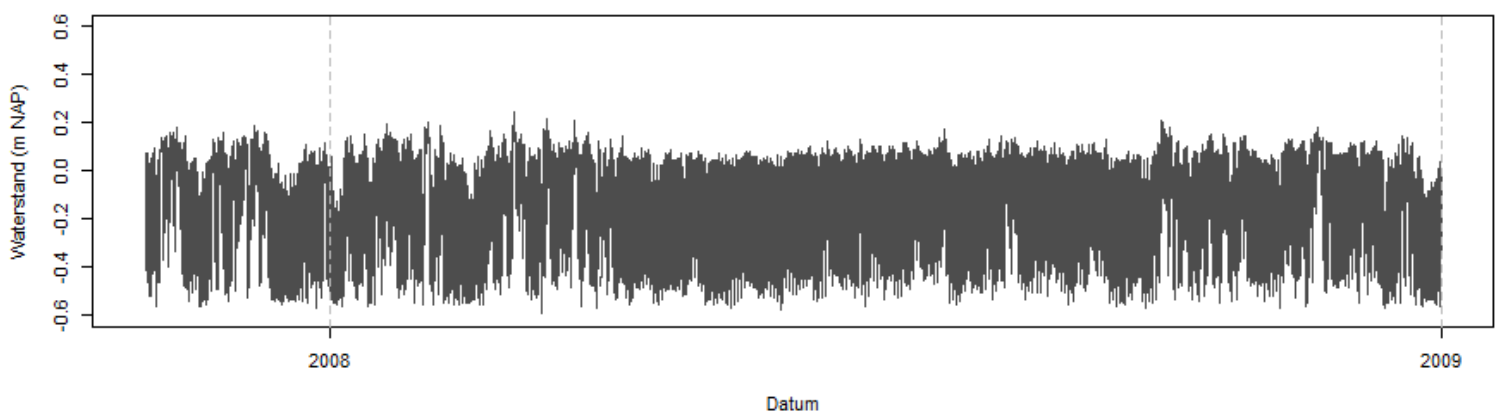

Figuur 23. Door het model berekende waterstanden voor het scenario 2 'RSV-Springtij' op de locaties GTSO.01, GTSO.12 en GTSO.20. 
Waterstanden Scenario: Getij30, Locatie: GTSO. 01

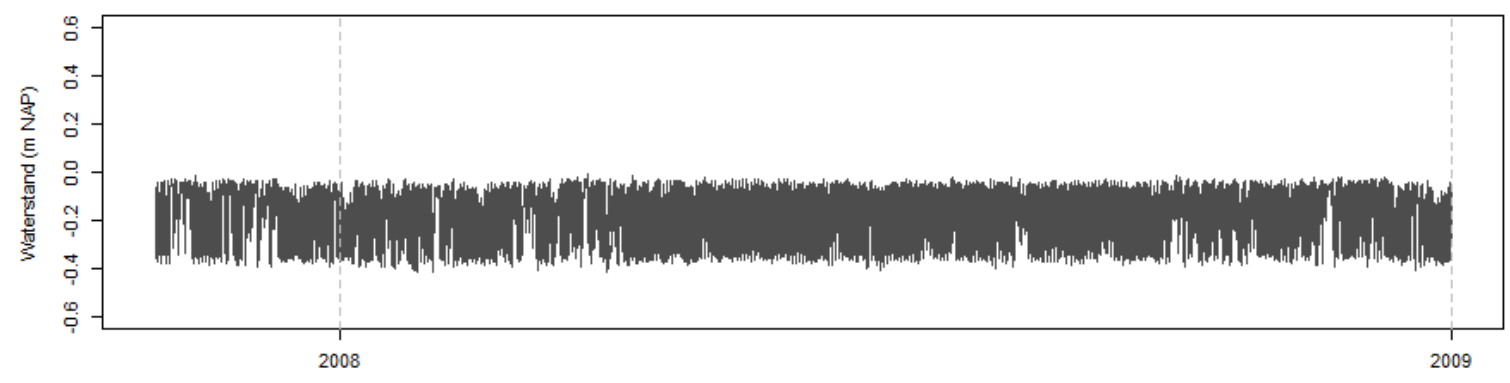

Datum

Waterstanden Scenario: Getij30, Locatie: GTSO.12

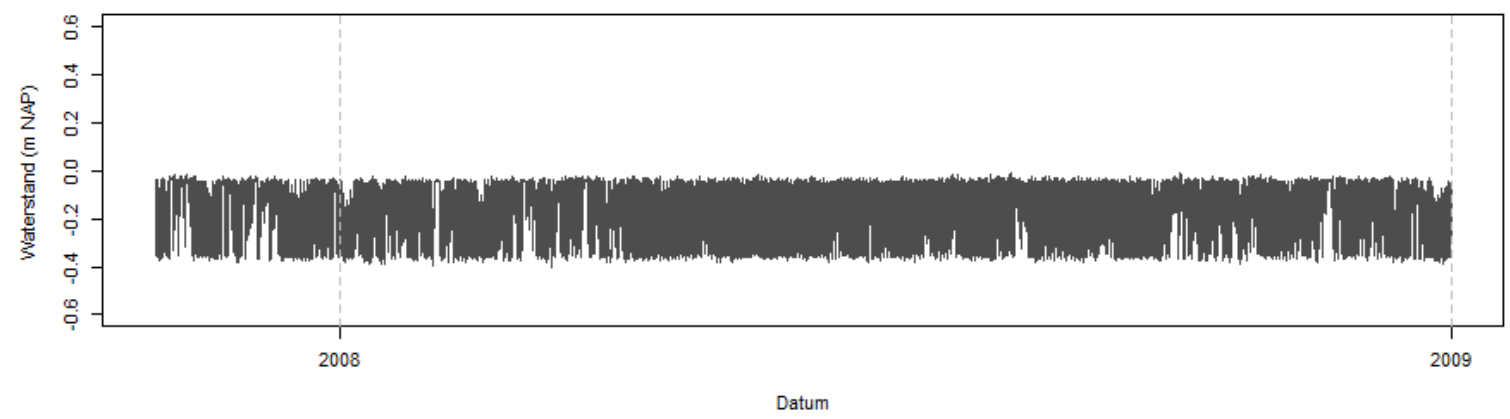

Waterstanden Scenario: Getij30, Locatie: GTSO.20

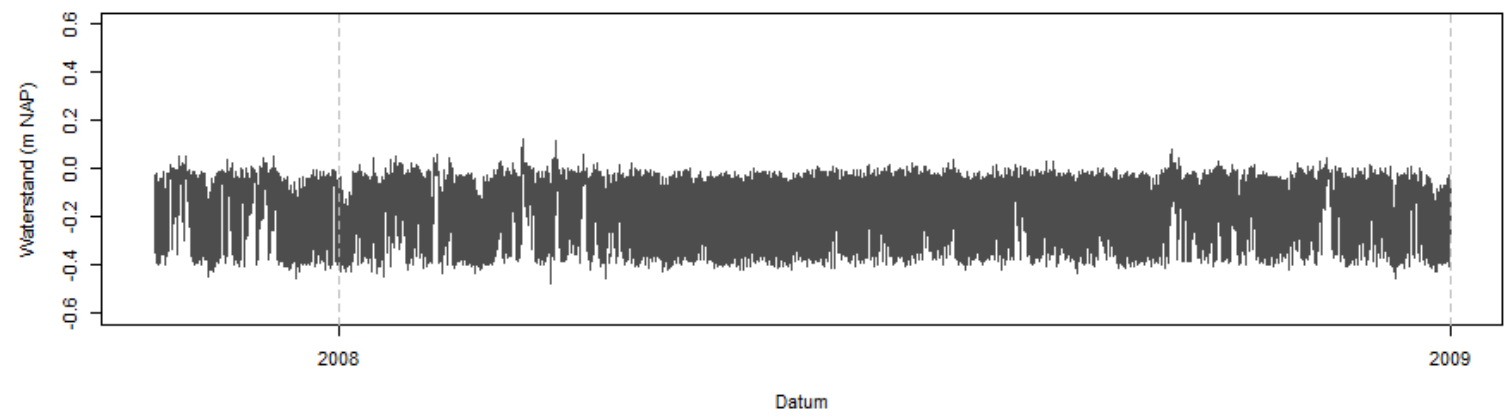

Figuur 24. Door het model berekende waterstanden voor het scenario 3 'Getij30' op de locaties GTSO.01, GTSO.12 en GTSO.20. 
Waterstanden Scenario: RSV-Peilbeheer, Locatie: GTSO.01

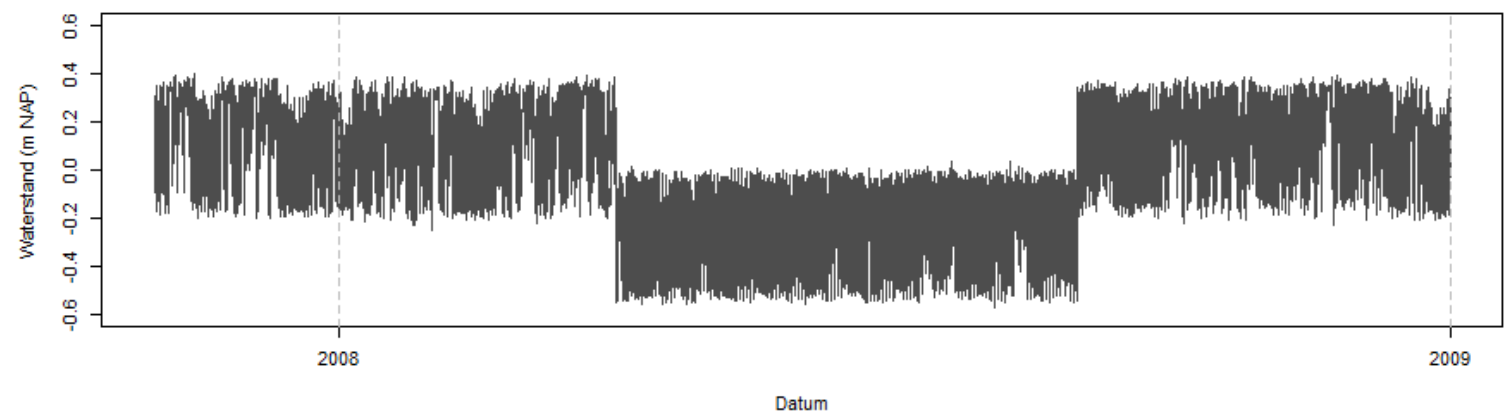

Waterstanden Scenario: RSV-Peilbeheer, Locatie: GTSO.12

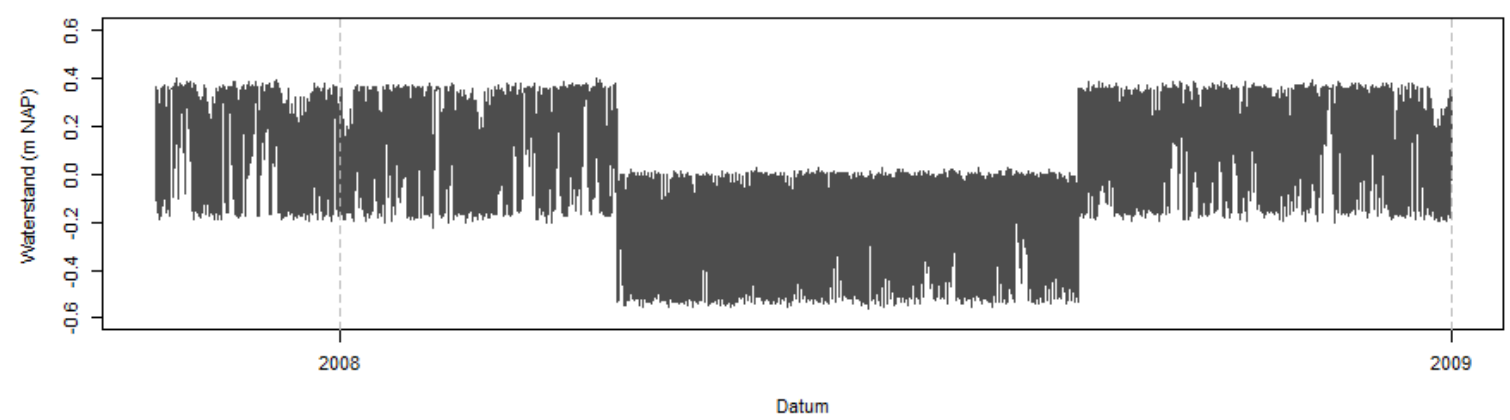

Waterstanden Scenario: RSV-Peilbeheer, Locatie: GTSO.20

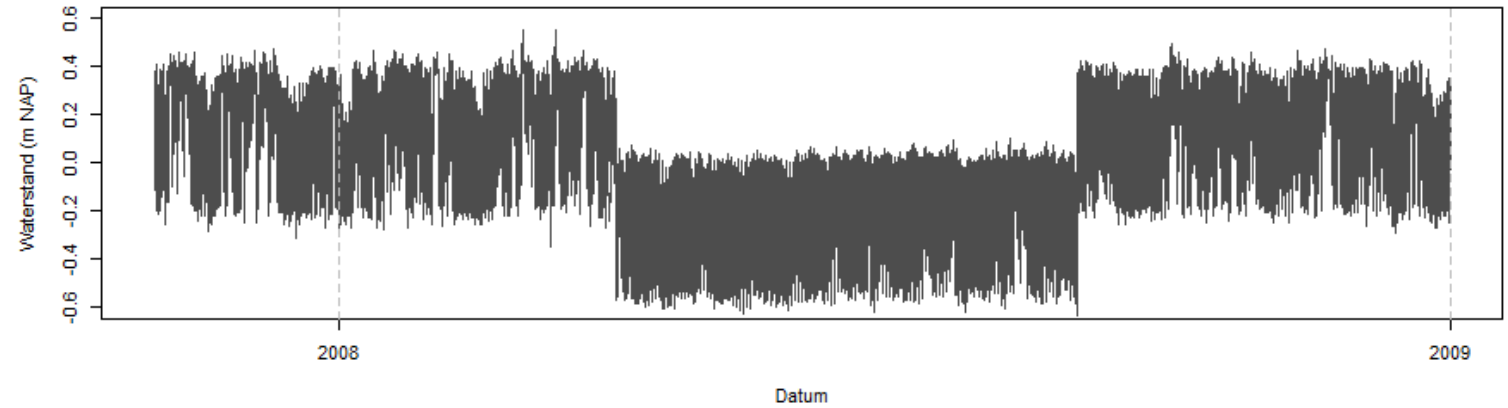

Figuur 25. Door het model berekende waterstanden voor het scenario 4 'RSV Peilbeheer' op de locaties GTSO.01, GTSO.12 en GTSO.20. 
Waterstanden Scenario: RSV-Zeespiegelstijging, Locatie: GTSO.01

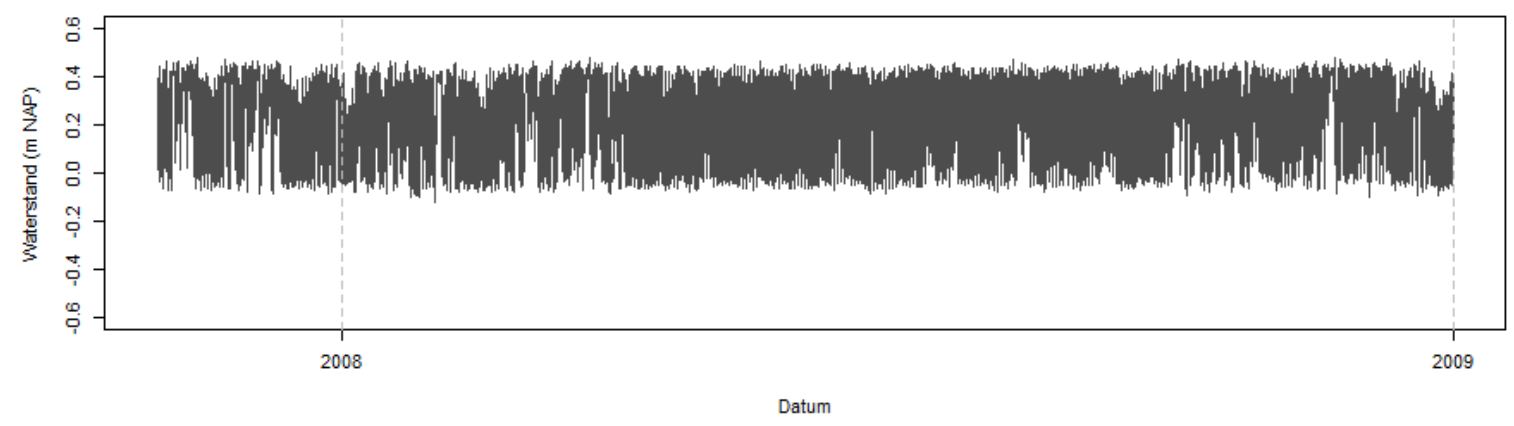

Waterstanden Scenario: RSV-Zeespiegelstijging, Locatie: GTSO.12

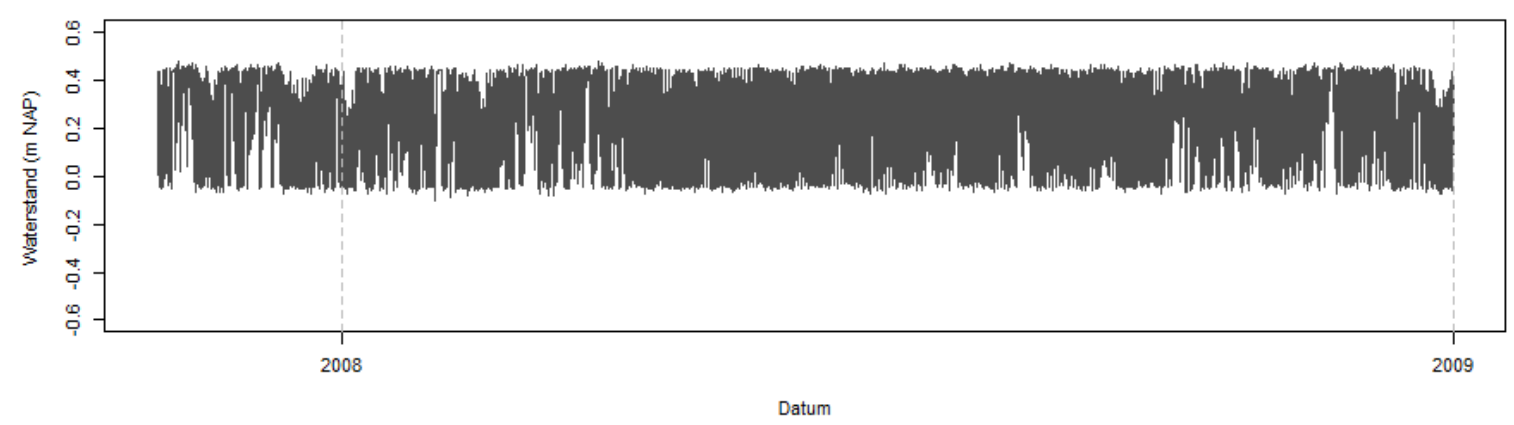

Waterstanden Scenario: RSV-Zeespiegelstijging, Locatie: GTSO.20

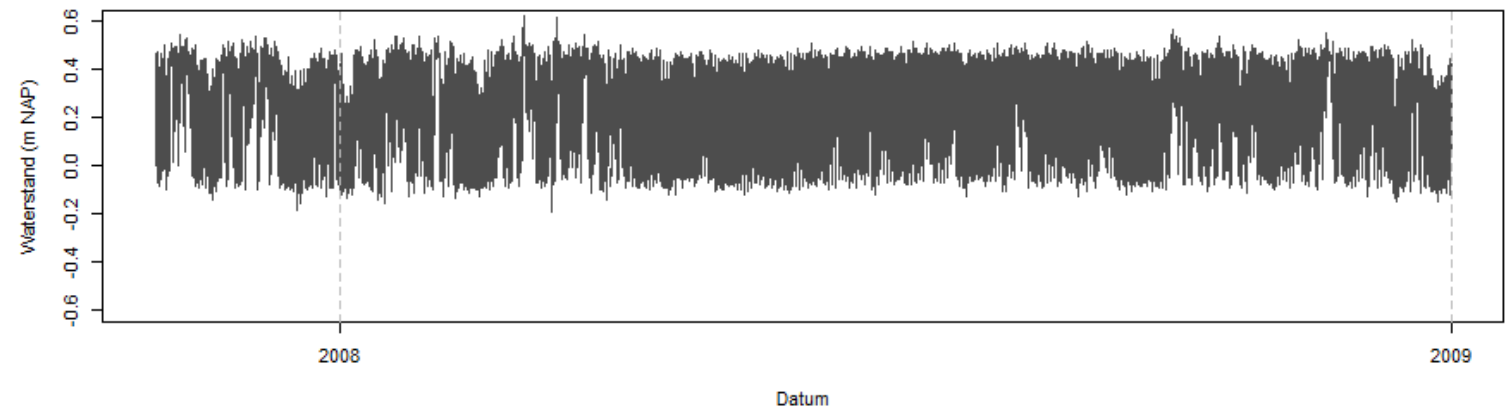

Figuur 26. Door het model berekende waterstanden voor het scenario 5 'RSV Zeespiegelstijging' op de locaties GTSO.01, GTSO.12 en GTSO.20. 


\section{G. Verslagen expertsessies}

BIJEENKOMST

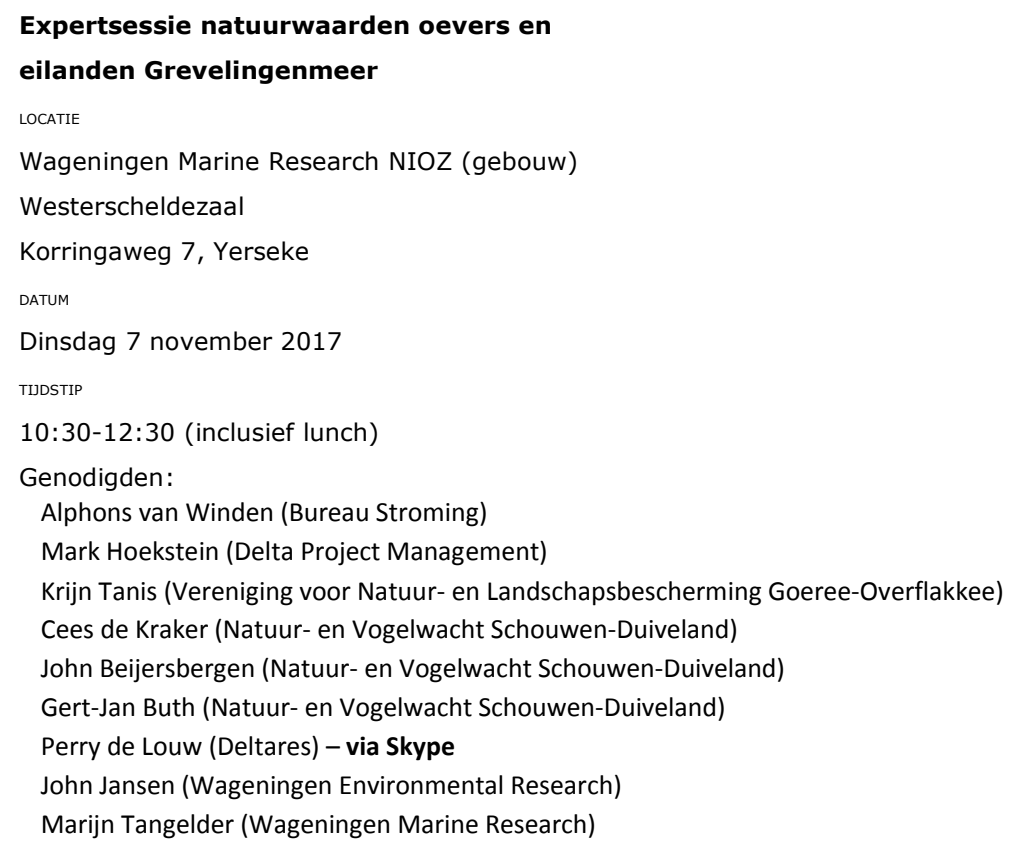

\section{Inleiding}

Marijn geeft een korte inleiding over de scenariostudie Grevelingenmeer. In het kader van het traject Rijksstructuurvisie (RSV) Grevelingen Volkerak-Zoommeer is nagedacht over het verbeteren van de waterkwaliteit van deze meren. Dit heeft geleid tot een voorkeursalternatief met een getijslag van 50 $\mathrm{cm}$ via een doorlaatmiddel in de Brouwersdam. Tot nu toe is in de planvorming vooral gekeken vanuit de invalshoeken waterkwaliteit, getijde energie, waterveiligheid en natuur(effecten). Hierbij is, volgens natuurorganisaties, maar beperkte aandacht geweest voor de kansen van herstel van estuariene natuur in het Grevelingenmeer enerzijds en is er ook de zorg over behoud van huidige waardevolle natuurwaarden anderzijds. Het ministerie van Landbouw Natuur en Voedselkwaliteit (opdrachtgever: Astrid Hilgers) vindt het van belang dat het perspectief en kansen voor natuur in het Grevelingenmeer wordt uitgediept in samenspraak met natuurpartijen en heeft Wageningen Marine Research in 2016 opdracht gegeven om dit te doen. Daartoe is het project 'Scenariostudie natuurperspectief Grevelingenmeer' gestart en zijn vijf scenario's uitgewerkt in overleg met natuurpartijen die resulteren in ecotopenkaarten bij verschillend waterbeheer.

De kaarten laten de eerste resultaten van deze studie zien. De ecotopenkaarten zijn een eerste stap in het begrijpen van de consequenties van veranderingen in waterbeheer voor ecologie. Met de ecotopenmethode kan berekend worden hoeveel areaal (in oppervlak) droogvallende delen ('terrestrisch') op de oevers en eilanden voorkomen in ieder scenario. De kaart geeft echter géén inzicht in welke verschillende typen vegetatie (bv. zilt grasland, vochtige duinvallei vegetatie etc.) er voorkomen en wat de gevolgen zijn voor broedvogels. Dit kan alleen met hulp van experts en gebiedskenners worden bediscussieerd. Daarnaast geven de ecotopenkaarten starre grenzen aan tussen land en water daar waar er in de realiteit veel meer fluctuaties optreden. Ook geven de ecotopenkaarten geen volledig realistisch areaal weer van de verwachtte ecotopen vanwege de onzekerheid in het oeverprofiel tussen $-0,20$ en $-1,5$ meter NAP.

Het doel van de expertsessie is dan ook om grip te krijgen op de verwachtte kwaliteit van natuurwaarden, veranderingen in de tijd en vooral ook het bediscussiëren van:

- $\quad$ In beeld brengen autonome ontwikkeling en effecten/kansen van getij.

- Optimalisatie van het peilbeheer ten bate van natuurwaarden (welke periode? Welke bandbreedte?)

- Gerichte beheersmaatregelen voor het vergroten van natuurwaarden

- Compenseren van natuurwaarden (bv. vochtige duinvallei vegetaties, broedvogel habitat) op hoger gelegen delen of in andere gebieden 


\section{Algemene punten:}

- Het Grevelingenmeer is een robuust systeem in die zin dat (met hulp van het beheer) 45 jaar na afsluiting nog steeds (tegen de verwachting in) relatief jonge waardevolle overgangsvegetaties voorkomen en broedgebied voor kustbroedvogels. Dit maakt het Grevelingmeer voor het voortbestaan van deze natuurwaarden zeer waardevol; zeker in vergelijking met andere bekkens zoals Veerse Meer en Volkerak-Zoommeer.

- De vochtige duinvalleivegetaties, en de zoute vegetaties en de overgangen tussen deze vegetatietypen zijn verreweg het waardevolst omdat deze vegetaties zowel nationaal als internationaal onder druk staan en langs de Grevelingen een groot areaal beslaan. Andere vegetatietypen zoals duindoornstruweel is minder bijzonder. Het onderzoek zou zich daarom vooral op de eerstgenoemde moeten richten voor wat betreft vegetatie.

- Ecotopen kaarten en arealen grafiek scheppen geen realistisch beeld van verlies aan waardevolle terrestrische natuurwaarden omdat alleen gedifferentieerd wordt tussen zoutminnende en zoete vegetatie. De arealen-grafiek doet vermoeden dat de vegetaties opschuiven. De waardevolle zoete vegetatietypen en in het bijzonder de vochtige duinvalleivegetaties, die niet naar boven op zullen schuiven, zijn niet zichtbaar. Het advies van de aanwezigen is om de habitattypen zichtbaar te maken en daarmee aan te geven wat verloren gaat.

- Het is van belang om winst en verlies bij de verschillende scenario's goed in kaart te brengen. Voor wat betreft de oevers en eilanden gaan waardevolle natuurwaarden verloren vanwege de afname van het areaal aan overgangsvegetaties tussen vochtige duinvalleivegetaties en zoute vegetaties en ook verdwijnen geschikte broedplaatsen voor o.a. kustbroedvogels en leefgebied voor de noordse woelmuis. Daarom is het van belang om goed in beeld te brengen wat er gewonnen wordt en aan te geven hoe verliesposten gecompenseerd kunnen worden, indien compensatie mogelijk is.

- Het is van belang om deze winst-verlies rekening ook in een groter perspectief te plaatsen. Wat is het maatschappelijk/publiek belang van getijde dynamiek en kansen voor foeragerende vogels ten opzichte van verlies van een waardevol vegetatietype en afname kustbroedvogels. Daarnaast zal het verlies van deze natuurwaarden juridisch gezien (Natura 2000) zeer lastig zijn.

\section{Vegetatie}

Huidige situatie en autonome ontwikkeling

Bij voortzetting van het huidige beheer van begrazing en maaien is de verwachting dat de vochtige duinvallei vegetaties bij een goed beheer nog heel lang kunnen voortbestaan. Door successie en beheer zal de vegetatie veranderen maar nog steeds zeer waardevol blijven. Samenstelling van vochtige duinvalleivegetatie is altijd aan verandering onderhevig als gevolg van successie. Soorten verschijnen anderen verdwijnen, nemen toe of af en sommige soorten houden het heel lang vol. Ook 50 jaar na dato zal er in de Grevelingen nog een waardevolle vochtige duinvalleivegetatie zijn (bij het gebruikelijk beheer van maaien en begrazen). Zolang de bodem gebufferd wordt door aanwezigheid van kalk of aanvoer daarvan door kalkrijke kwel, zoutspray of incidentele overspoeling kunnen de soorten die daarvan afhankelijk zijn blijven voorkomen (zoals bijv. op het 300 jaar oude Kapenglop op Schiermonnikoog).

De zoetwaterlens die ontwikkelt in de bodem van de eilanden is sterk afhankelijk van het gemiddelde waterpeil. Streefpeilen zijn een middenpeil van -0,20 meter NAP (winterpeil) en een zomerpeil van 0,26 meter NAP. Maar in de realiteit kunnen de waterstanden niet precies op deze grenzen gehouden worden en bestaat er een bandbreedte van -0,10 tot -0,30 meter NAP waarbinnen het waterpeil fluctueert als gevolg van harde wind op het meer zelf, waardoor opwaaiing optreedt, of door storm op zee, waardoor er geen water in- of uitgelaten kan worden via de Brouwerssluis. In de toekomstige situatie zullen deze onregelmatige waterstandsfluctuaties ook nog op te treden maar dan vallen ze wel grotendeels weg binnen de marges van $50 \mathrm{~cm}$ getij.

De zoute vegetaties zullen in de huidige situatie met het huidige beheer nog iets afnemen als gevolg van het geleidelijk verzoeten van de oever. De zoetwaterlens groeit nog steeds langzaam naar de oever toe en drukt het zoute water weg. 
Overgangsvegetaties op de grens van zoet en zout

Het meest waardevolle habitat in het Grevelingenmeer zijn de overgangsvegetaties van zoete vochtige duinvallei vegetaties naar zoute vegetaties met (pionier). Dit waarborgt een hoge soortenrijkdom van relatief zeldzame soorten.

Bij introductie van getij kunnen zoute vegetaties veelal maar gedeeltelijk opschuiven, want:

1. hogerop is het profiel / de hellingshoek vaak steiler (minder ruimte), of er ligt een klifje waardoor er nauwelijks areaal is op een iets grotere hoogte.

2. aanwezigheid van struweel/ruigte en zoetwaterbel belemmert de verzilting.

3. doordat het getij wordt begrensd aan de bovenzijde (de inlaat van water stopt zodra het HWniveau is bereikt) zullen onregelmatige hogere mogelijk waterstanden minder vaak voorkomen. Dit is afhankelijk van het beheer van het doorlaatmiddel.

4. het gebied is al grotendeels zilt (Markenje).

Zoute vegetaties kunnen dus maar op een beperkt aantal plekken opschuiven naar hoger gelegen delen. Onder invloed van windopzet en spatwater zal zich een zoute oeverzone ontwikkelen waar zoute vegetaties voorkomen. Deze zone is smaller dan in de huidige situatie waar zoute vegetaties ook nog profiteren van zout uit de bodem wat nog aanwezig is van voor de afsluiting. Omdat een heel groot deel van de huidige zoute vegetaties in onbegroeid intergetijdengebied verandert en de zoute vegetaties maar gedeeltelijk kunnen opschuiven, vanwege de bovengenoemde oorzaken, zal het oppervlak hiervan na invoering van gedempt getij afnemen. Dit wordt nog versterkt als de middenstand gaat meereizen met de zeespiegelstijging, omdat er op grotere hoogte steeds minder areaal beschikbaar is. Daarbij zullen de zoute vegetaties zich niet kunnen ontwikkelen op de hoger gelegen bodems die nu zoet zijn. Gericht peilbeheer als aanvulling op het getij van $50 \mathrm{~cm}$, bijvoorbeeld door het peil 's winters tijdens enkele hoogwaterperioden nog 10 of $20 \mathrm{~cm}$ hoger op te zetten is daarom nodig voor ontwikkeling van zoute vegetaties. Hier ligt een mogelijkheid voor optimalisatie.

Duinvalleivegetaties kunnen vrijwel nergens heen opschuiven en zullen verzilten en verdwijnen. Dit zal met name ten koste gaan van de zeer waardevolle laag gelegen overgangsvegetaties naar het vochtige duinvalleitype waar zich al of niet tijdelijk een dunne zoetwaterlens heeft ontwikkeld, met soorten als Groenknolorchis, Vleeskleurige orchis en Armbloemige waterbies.

Dat de vochtige duinvalleivegetaties niet opschuiven komt doordat:

1. Er verandert niets aan de bovengrens: fysieke beperking door struweel, stuifrug, schorrand, voedselrijke ruigte of de bodem is daar te voedselrijk of het verloop van de grondwaterstand voldoet niet aan eisen (bv. te grote peilverschillen).

2. Duinvalleivegetaties komen op diverse locaties reeds over het hele traject tot aan de bovengrens (dijk) voor.

Op locaties waar daar wel ruimte voor is, zullen overgangsvegetaties (dunne zoetwaterlens/weinig ontwikkeld bodemprofiel) na de instelling van het getij binnen het vegetatietype vochtige duinvallei vrijwel niet opschuiven doordat het bodemprofiel zich hogerop sinds de afsluiting van de Grevelingen al meer ontwikkeld heeft (dikte humuslaag) en het verloop van de grondwaterstanden niet aan de eisen voldoet (gemiddeld lager, zie verderop). Zo komt bijv. basenrijk grondwater minder snel aan het maaiveld.

Sediment: de platen zijn fijnzandig met 3-8\% lutum (afgezien van het oude schor op de Hompelvoet) met plaatselijk 'sliblenzen'. De Slikken van Flakkee bevatten een iets hogere lutum component dan op de platen met een toenemende gradiënt richting de dijk. Daarmee neemt ook de voedselrijkdom toe. Deze voedselrijkdom zorgt er ook voor dat het lastig is voor vochtige duinvallei vegetaties om daarheen op te schuiven.

\section{Invloed getij op grondwater}

Bij een situatie met getij maar met een middenstand gelijk aan het huidige peil $(-20 \mathrm{~cm} N A P)$ zal de grondwaterlens dunner worden als gevolg van de wisselende waterstanden. Dit is aangetoond vanuit modelberekeningen. Dit komt omdat bij laagtij (groot potentiaal verschil) drainage sneller gaat dan de opbouw van de zoetwaterlens (tegen de zwaartekracht in) bij hoogtij. Daarnaast zal het freatisch vlak lager komen te liggen als gevolg van de drainage. De gemiddelde grondwaterstand in een getijdesituatie zal dus iets dalen.

Het is de verwachting dat het freatisch grondwater niveau op de plekken die niet draineren evenveel omhoog zal gaan als een eventuele stijging van het middenpeil op termijn bij zeespiegelstijging. Daardoor zal vernatting optreden en freatisch vlak op de laaggelegen delen het maaiveld bereiken. Deze 
vernatting wordt versterkt door de bodemvorming die op sommige delen al plaatsvindt (bv. de Hompelvoet) waardoor het water langer vastgehouden wordt. Deze natte situatie is ongunstig voor vochtige duinvalleivegetaties en leidt in langdurige situaties tot rotten van de wortelknollen. Vooral op relatief vlakke platen als Veermansplaat en Stampersplaat zal dit grote gevolgen hebben.

Kennisvraag: wat is de exacte ontwikkeling van de zoete grondwaterlenzen in een getijde situatie?

In het scenario peilbeheer is er een opzet van het middenpeil (bij $50 \mathrm{~cm}$ getijslag) naar $+0,10$ meter NAP in de winter en naar -0,26 meter NAP gedurende 3 maanden. Ook hier zal de grondwaterlens dunner worden ten opzichte van de huidige situatie door hetzelfde proces van drainage die sneller gaat dan de opbouw van de lens in de wintermaanden. Dit is ook afhankelijk van hoe het peil wordt opgezet: in één keer omhoog of omlaag of in stappen. Als het peil in één keer wordt opgezet dan zullen de oevers geïnfiltreerd worden met zout water. Als met in de zomer in één keer zou verlagen dan treedt er een groot potentiaal verschil op waardoor er drainage ontstaat. Door deze grote fluctuaties zal de zoete grondwaterlens dunner worden.

\section{Kansen / optimalisatie}

\section{Vochtige duinvallei vegetaties}

Zoals eerder aangegeven zullen vochtige duinvallei vegetaties op de meeste plaatsen niet of nauwelijks opschuiven vanwege fysieke barrières zoals aanwezigheid van struweel en meer voedselrijke bodem op de hogere delen of het ontbreken terrein met een geschikte bodemhoogte. Een mogelijkheid is om het struweel te verwijderen en de bodem af te plaggen tot net boven de nieuwe grondwaterstand. Hiermee worden omstandigheden gecreëerd die in principe gunstig zijn voor vochtige duinvallei vegetaties om te ontwikkelen. Hierbij worden de volgende kanttekeningen geplaatst:

- Het gaat langs de Grevelingen om vele tientallen tot honderden hectares dus dit vraagt een flinke inspanning (zoals soms ook in de duinen wordt gedaan).

- Op plaatsen waar struweel aanwezig is zal diep geplagd moeten worden om alle wortels te verwijderen. Daarnaast komt het maaiveld door het afplaggen ook weer lager te liggen en daarmee mogelijk ook binnen de invloed van het zoute water.

- Op laaggelegen platen zoals de Veersmansplaat waar juist relatief grote oppervlakten van vochtige duinvallei vegetaties voorkomen is deze ruimte er niet.

\section{Zoute vegetaties}

Twee maal per jaar een extra hoge peilopzet als aanvulling op de getijdenslag zal de verzoeting van de oever tegengaan en dit is gunstig voor behoud en ontwikkeling van zoute vegetaties. Dit zou bijvoorbeeld een opzet van $10 \mathrm{~cm}$ kunnen zijn begin september (als alle vogels zijn uitgebroed) en eind maart voordat het broedseizoen begint.

\section{Samenvatting vegetatie:}

Opschuiven van de vegetaties is vaak niet mogelijk. Introductie van getij zal grotendeels ten koste gaan van de vochtige duinvalleivegetaties. Ook het areaal aan zoutvegetatie zal afnemen bij instelling van getij. Een en ander dient voor de verschillende scenario's te worden gekwantificeerd. Bij de mogelijkheden voor compensatie moet men zich realiseren dat het daarbij om grootschalige ingrepen gaat als het rooien van struweel/bos en het plaggen van humeuze bodems. In de huidige situatie hebben zowel de duinvalleivegetaties als de zout-zoetovergangen bij een goed beheer een relatief duurzaam karakter.

\section{Broedvogels}

Huidige situatie en autonome ontwikkeling

Het peilbeheer in de huidige situatie (met een $6 \mathrm{~cm}$ lager zomerpeil dan winterpeil) zorgt ervoor dat grondbroedende vogels veiliger kunnen broeden met een vermindert risico dat de nesten onderlopen. Een selecte groep van soorten zoals de Dwergstern en Kluut broeden op de hogere delen in de zone die net droogvalt. Dit heeft met de vereiste openheid te maken die deze soorten prefereren. Het lagere peil in de zomer vermindert het risico op overspoeling van de nesten bij langdurig harde wind. Het lagere peil zorgt ook voor een verbeterde drainage waardoor het regenwater beter weg kan en de kans kleiner is dat de nesten onderlopen door plasvorming bij heftige regenval.

De Grevelingen is van bijzondere betekenis voor de Strandplevier omdat bijna de helft van de strandplevieren in Nederland op de oevers van het Grevelingenmeer broedt. Omdat Strandplevieren solitaire broeders zijn hebben ze ook de ruimte nodig om te kunnen broeden. 
Het Grevelingenmeer is, zelfs na 45 jaar nog steeds een waardevol gebied om te broeden. Uiteraard is beheer wel noodzakelijk om deze broedgebieden in stand te houden. Het Grevelingenmeer met eilanden in het zoute water blijkt blijvend geschikt te kunnen zijn als broedgebied in vergelijking met andere locaties (bijvoorbeeld het Veerse Meer). De Hompelvoet is echter een voorbeeld van een gebied wat te terrestrisch geworden is en waar kustbroedvogels minder tot broeden komen. Daarnaast is de opkomst van predatoren zoals de vos en roofvogels ook een bedreiging voor broedvogels in de toekomst wat sommige delen van het Grevelingenmeer mogelijk minder geschikt maakt.

\section{Effecten}

Huidige broedgebieden voor kustbroedvogels bevinden zich juist op de laaggelegen delen van o.a. Slikken van Bommenede, Markenje en de Slikken van Flakkee. Bij het invoeren van gedempt getij zullen deze gebieden overspoelen en verloren gaan. Hoe hoger het water komt hoe meer verlies van broedbiotoop.

Op een robuuste kale zone met aangrenzend grasland van $>500$ meter kunnen kustbroedvogels en weidevogels terecht. Bij gedempt getij zal er maar een beperkt deel van deze zone overblijven. De verwachting is echter dat deze vogels op een strook van 100 meter langs de bosrand waar potentiële predatoren zoals haviken en kraaien voorkomen, niet zullen terugkeren (Slikken van Bommenede, Slikken van Flakkee-Noord).

Met gerichte maatregelen zijn deze effecten enigszins te mitigeren maar niet voor alle soorten zoals bijvoorbeeld de strandplevier die een groot areaal en een bepaalde robuustheid nodig heeft.

\section{Kansen / optimalisatie}

\section{Peilbeheer}

Broedvogels hebben baat bij van oorsprong natuurlijke fluctuaties in waterstanden door meer stormen in de winter (opzet) en relatief rustige perioden in de zomer waarbij de kale delen als broedgebied fungeren. Het is van belang om een peilbeheer na te bootsen die zorgt voor deze kale zones langs de oevers en daarmee voldoende groot areaal aan geschikt broedbiotoop oplevert.

Een voorbeeld van voor broedvogels geschikt peilbeheer:

Winterpeil: Eind augustus-Maart vast op -0,20 m NAP met schommelingen tussen -0,25 en 0 m NAP

Zomerpeil: April-Eind augustus vast op $-0,25$ m NAP met schommelingen tussen $-0,25$ en $-0,30$ m NAP Incidenteel: tweemaal per jaar tot $+0,06 \mathrm{~m}$ NAP begin september (niet eerder vanwege broedende sterns) en begin maart. Dit is ook gunstig voor het tegengaan van vegetatieontwikkeling op de kale slikken en voor de ontwikkeling van zoute vegetaties op de grens van zoet en zout door het verzilten van de bodem waarmee de ontzilting tegen gegaan wordt. In een getijde situatie kun je ook een dergelijk peilbeheer toepassen. Dat betekend wel dat het beheer van het doorlaatmiddel de ruimte moet kunnen bieden om incidenteel waterstanden boven GHW toe te staan.

In het winterseizoen is het ook niet bezwaarlijk om extra opzet bij storm toe te laten.

\section{Maatregelen}

Eilanden zullen opgehoogd moeten worden om boven het getij uit te komen, bijvoorbeeld Markenje en de Kleine Stampersplaat. Dit gaat om tientallen hectares. Ook zullen deze gebieden beheerd moeten worden om successie tegen te gaan; of ze moeten in het winterseizoen enkele malen kunnen overstromen met zout water. Op sommige plekken zullen broedvogels wellicht niet terugkeren omdat het gebied niet meer robuust genoeg is.

Aanleg van broedgebieden, zoals bijvoorbeeld opspuiten van broedeilanden, biedt vooral kansen voor kolonie broedende vogels zoals sterns, meeuwen. Eén geschikt broedgebied is niet genoeg. Soorten zoals de grote stern zijn opportunistisch en bekijken per jaar waar ze willen broeden. Bijvoorbeeld als er predatoren aanwezig zijn op Markenje kunnen ze uitwijken naar een andere locatie. Robuustheid is van belang.

Met gerichte inspanningen kan men relatief eenvoudig kansen creëren voor broedvogels. Introductie van getij zou geen probleem moeten zijn als voorzien wordt in mitigerende maatregelen voor broedvogels. Dit gaat echter niet voor alle soorten op. Je kunt bijvoorbeeld een drijvende voorziening creëren waar Visdieven kunnen broeden. Voor Grote Sterns wordt het al lastiger. De Strandplevier, waar het Grevelingenmeer nu juist zo waardevol voor is, heeft vooral een groot areaal aan robuuste gebieden nodig en dat is lastiger te realiseren. 
Aanleg van een eiland in de Voordelta is ook een mogelijkheid; zoals bijvoorbeeld Griend in het Waddengebied. Dit is gunstig voor het hele Deltagebied. Anderen zijn van mening dat deze maatregel niet voldoende is om de effecten op broedvogels te compenseren. Benadrukt wordt dat een combinatie van meerdere maatregelen nodig is om te kunnen mitigeren. Ook dan zal dit niet alle soorten kunnen bedienen.

\section{Toekomstige voedselsituatie}

Meeuwen kunnen mogelijk profiteren van introductie van getij omdat zij profiteren van het intergetijdengebied en met name voedsel op de droogvallende stenen oeververdedigingen. De grotere meeuwensoorten (die meer algemeen zijn) vormen echter ook weer een bedreiging (predatie) voor bijvoorbeeld sternen (zeldzamere soort). De Zilvermeeuw heeft het de laatste jaren echter ook moeilijk.

\section{Samenvatting kustbroedvogels}

Ook na 45 jaar is de Grevelingen van groot belang voor kustbroedvogels en kan dat bij een goed beheer nog lang blijven. Dat heeft te maken met het zoute water en de grootschaligheid van het gebied. Bij invoering van getij zal de ruimtelijke schaal van het broedgebied verminderen en zullen deze soorten in aantal afnemen. Voor kolonievogels als sterns en meeuwen kan gecompenseerd worden door aanleg van broedeilanden. Bij invoering van getij worden de bestaande eilanden ongeschikt en dienen extra beheersmaatregelen te worden getroffen. Voor soorten als de strandplevier is het lastiger compenseren omdat dit een solitaire broeder is die over het algemeen het beste broed op droogvallende, kale slikken.

\section{Noordse woelmuis}

Het leefgebied van de noordse woelmuis zal flink afnemen bij invoeren van getij. Juist omdat de Noordse Woelmuis vooral voorkomst op laaggelegen delen met grasruigte (bv. Markenje, Slikken van FlakkeeNoord), die door het getij veranderen in intergetijdengebied. Zoals we hierboven al zagen zal deze vegetatie maar weinig naar hogerop op kunnen schuiven. De verwachting is daarom dat ook het leefgebied van de Noorse Woelmuis afneemt. De soort leeft vooral in ruige vochtige grasvegetaties en kruidenrijk rietland. Gebieden die geregeld overstromen (bijvoorbeeld bij springvloed) zijn ongeschikt, evenals zilte vegetaties. Het gaat in de Grevelingen vooral om brakke tot zoete ruigte die niet of vrijwel niet begraasd wordt, want daar kan de Noordse woelmuis slecht tegen. De belangrijkstee gebieden voor de noordse woelmuis in de Grevelingen zijn: Slik de Kil (Punt van Goeree), Markenje en de Slikken van Flakkee-Noord, allemaal niet begraasde gebieden. Bij invoering van getij neemt op deze locaties het geschikte areaal af doordat een deel van het huidige leefgebied onder invloed van het getij komt en de zone met brakke ruigte niet kan opschuiven zoals bij Markenje (heel het hogere deel van 8,5 ha is nu prima leefgebied) en bij de overige twee gebieden alleen wanneer een brede strook van het aanwezige struweel verwijderd wordt. Bovendien is het onzeker of zich op deze strook geschikt habitat zal ontwikkelen. Vermoedelijk zullen dergelijke gebieden is de toekomst ook meer beheer vragen zoals heel af en toe maaien. Incidenteel extra hoge waterstanden kunnen daarbij ook een hulpmiddel zijn. 
BIJEENKOMST

\section{Verslag expertsessie perspectief natte natuurwaarden Grevelingenmeer}

LOCATIE

Deltares kantoor

Zaal: Innovation

Boussinesqweg 1

2629 HV Delft

DATUM

Donderdag 16 november 2017

TIJDSTIP

13:00-15:00

\section{Genodigden:}

Martijn Verweijen (Werkgroep Beter Zicht op de Grevelingen) (verhindert)

Floor Arts (Delta Project Management)

Peter Herman (Deltares)

Arjen Boon (Deltares)

Bernadette Botman (B2 Consultancy)

Alphons van Winden (Bureau Stroming)

Paul Paulus (RWS)

Silvana Ciarelli (RWS)

Arno Nolte (Deltares)

Tom Ysebaert (Wageningen Marine Research/NIOZ)

Marijn Tangelder (Wageningen Marine Research)

\section{Inleiding}

Marijn geeft een korte inleiding over de scenariostudie Grevelingenmeer. In het kader van het traject Rijksstructuurvisie (RSV) Grevelingen Volkerak-Zoommeer is nagedacht over het verbeteren van de waterkwaliteit van deze meren. Dit heeft geleid tot een voorkeursalternatief met een getijslag van 50 $\mathrm{cm}$ via een doorlaatmiddel in de Brouwersdam. Tot nu toe is in de planvorming vooral gekeken vanuit de invalshoeken waterkwaliteit, getijde energie, waterveiligheid en natuur(effecten). Hierbij is, volgens natuurorganisaties, maar beperkte aandacht geweest voor de kansen van herstel van estuariene natuur in het Grevelingenmeer enerzijds en is er ook de zorg over behoud van huidige waardevolle natuurwaarden anderzijds. Het ministerie van Landbouw Natuur en Voedselkwaliteit (opdrachtgever: Astrid Hilgers) vindt het van belang dat het perspectief en kansen voor natuur in het Grevelingenmeer wordt uitgediept in samenspraak met natuurpartijen en heeft Wageningen Marine Research in 2016 opdracht gegeven om dit te doen. Daartoe is het project 'Scenariostudie natuurperspectief Grevelingenmeer' gestart en zijn vijf scenario's uitgewerkt in overleg met natuurpartijen die resulteren in ecotopen kaarten bij verschillend waterbeheer.

De kaarten laten de eerste resultaten van deze studie zien. De ecotopenkaarten zijn een eerste stap in het begrijpen van de consequenties van veranderingen in waterbeheer voor ecologie. Met de ecotopenmethode kan berekend worden hoeveel areaal (in oppervlak) droogvallende delen ('terrestrisch') op de oevers en eilanden voorkomen in ieder scenario. De kaart geeft echter géén inzicht in welke verschillende typen vegetatie (bv. zilt grasland, vochtige duinvallei vegetatie etc.) er voorkomen en wat de gevolgen zijn voor broedvogels. Dit kan alleen met hulp van experts en gebiedskenners worden bediscussieerd. Daarnaast geven de ecotopenkaarten starre grenzen aan tussen land en water daar waar er in de realiteit veel meer fluctuaties optreden door o.a. windgedreven peilverschillen. Ook geven de ecotopenkaarten geen volledig realistisch areaal weer van de verwachtte ecotopen vanwege de onzekerheid in het oeverprofiel tussen $-0,20$ en $-1,5$ meter NAP.

Het doel van de expertsessie is om grip te krijgen op de verwachtte kwaliteit van natuurwaarden en kansen gericht op:

- Inschatten ecologische veranderingen van het watersysteem en betekenis voor soortengroepen

- Ontwikkeling en ecologische betekenis van de intergetijdengebieden die ontstaan bij invoering van getij.

\section{Ontwikkeling Grevelingenmeer na afsluiting}

Sinds de afsluiting hebben er enorme verschuivingen plaatsgevonden onder verschillende soorten en soortengroepen. Grote oppervlakten zeegras ontwikkelden zich en namen later gestaag weer af tot het 
uitendelijk geheel verdween. Ook onder de bodemdieren vonden grote verschuivingen plaats met ontwikkeling van 'verworming', afname van soortenrijkdom en dichtheden in de ondiepe zone (2-3 meter diepte) die niet beïnvloed wordt door zuurstofloosheid. De eerste (nog ongepubliceerde) uitkomsten van een bestandsschatting van natuurlijke schelpdierbestanden in 2017 in het kader van de monitoring wettelijke onderzoekstaken (Dr. Karin Troost) laten zien dat de dichtheden van schelpdieren zeer laag zijn in de ondiepe zone tot 3 meter in vergelijking met het Veerse Meer. Het is onbekend hoe dit komt. Mogelijk heeft dit met een hoge predatiedruk door garnalen te maken. Beperkt voedselaanbod al dan niet gecombineerd met de geringe aanvoer door beperkte stroming zou ook mee kunnen spelen. Waarom in het Veerse Meer wel schelpdieren ontwikkelen in de ondiepe zone is niet bekend. Mogelijk komt dit door betere broedval van schelpdieren in het Veerse Meer doordat het zoutgehalte daar iets lager is dan in het Grevelingenmeer en spelen predatoren een minder sterke rol.

Daarnaast zijn sterke fluctuaties in visstand waargenomen die mogelijk gerelateerd zijn aan vormgeving van het doorlaatmiddel in de Brouwersdam. Eerst is hier een sifon geplaatst waardoor vissen naar binnen konden zwemmen maar niet naar buiten. Later is de Brouwerssluis aangelegd waardoor ook een veel groter debiet Noordzee water naar binnen kon stromen waardoor vissen makkelijk in en uit konden migreren. De visstand is in de jaren '60-'80 jaarlijks gemonitord en daarna incidenteel met wisselende focus en gebruik van monstertuigen. In het voorjaar van 2017 is een studie uitgevoerd door ATKB om grip te krijgen op de huidige visstand in het Grevelingenmeer. Deze studie laat zien dat marien juveniele soorten (vnl. haring en sprot) in relatief hoge dichtheden voorkomen in het westelijk deel nabij de Brouwerssluis. Deze vissen trekken echter niet verder het meer in wat aangeeft dat dit waarschijnlijk niet aantrekkelijk voor ze is. Mogelijk is dit gerelateerd aan waterbeweging en voedsel. Larven en jong juvenielen zijn vooral stroming gedreven, dus als stroming ontbreekt zullen ze niet verder het meer opzwemmen.

In de jaren negentig zijn duizenden futen (viseters) geteld in de winter ook in het westelijke deel. Later zijn deze aantallen gedecimeerd tot enkele tientallen. Mogelijk hebben futen geprofiteerd van de vissen die tijdelijk 'gevangen' zaten of ligt de oorzaak in het optreden van zuurstofloosheid en de effecten op het bodemleven. In de huidige situatie komen middelste zaagbekken en geoorde futen verspreid over het hele Grevelingenmeer voor en zijn naar verwachting niet afhankelijk van haring en sprot in het westelijke deel. Mogelijk foerageren de geoorde futen op garnalen ook omdat ze vooral in de ondiepe delen voorkomen.

Het voorgaande geeft aan dat er grote ecologische verschuivingen hebben plaatsgevonden die nog altijd niet goed begrepen worden. Het is onmogelijk om verschuivingen in visstand en vogelaantallen te verklaren zonder grip te hebben op wat er gebeurd aan de basis van het voedselweb (primaire productie, zooplankton en bodemdieren). Gegevens daarover ontbreken echter in voldoende mate; wel is duidelijk dat het voedselaanbod in de loop der tijd steeds kleiner is geworden.

\section{Verandering van het watersysteem en voedselweb bij getij}

Arno geeft een korte inleiding over actuele kennis met betrekking tot systeem veranderingen in het Grevelingenmeer bij invoering van getij vanuit een eerder uitgevoerde modelstudie. Deltares heeft vorig jaar in kaart gebracht wat resterende kennisvragen zijn op het gebied van abiotische aspecten en primaire productie (synthese document). Habitats en soorten zijn buiten beschouwing gelaten omdat dit grotendeels al in de Natuureffecten studie was samengevat. Hij presenteert een conceptueel model wat laat zien welke processen van belang zijn bij invoering van getij: connectiviteit, stroming, ontstaan van intergetijdengebieden, effecten grondwaterstand, doorzicht, zuurstofloosheid, verandering in aanvoer van nutriënten die van invloed zijn op de primaire productie en doorwerking in het voedselweb. De effecten van getij op de zuurstofproblematiek zijn in kaart gebracht met als uitgangspunt het jaar 2008 (het "ergste" jaar). Bij $30 \mathrm{~cm}$ getij laat het model zien dat in "gunstige" jaren de zuurstofloosheid beperkt blijft maar in een ongunstig jaar - dat wil zeggen warm en windstil zodat temperatuurstratificatie kan opbouwen en langdurig in stand kan blijven - nog kan uitbreiden naar een flink areaal. Hierbij is uitgegaan van een zuurstofloosheid van $>3 \mathrm{mg} / \mathrm{l}$ die zeven dagen of langer aanhoud. Bij $30 \mathrm{~cm}$ getij lijkt er daarom nog sprake een kantelpunt waarbij afhankelijk van o.a. temperatuur grote arealen zuurstofloosheid kunnen optreden maar bij een grotere getijslag vlakt dit effect sterk af. Bij het voorkeursscenario van $50 \mathrm{~cm}$ getij treedt er alleen in de diepe westelijke putten >15-20 meter waterdiepte nog zuurstofloosheid op.

\section{Primaire productie}

Het Grevelingenmeer is stikstof (nitraat) gelimiteerd wat betekent dat de groei van algen wordt beperkt door stikstof en bijvoorbeeld niet door licht- of fosfaatlimitatie. Bij $50 \mathrm{~cm}$ getij ontstaat er meer uitwisseling met de Noordzee waardoor stikstof van buiten wordt aangevoerd. De verwachting is dat de 
aanvoer beperkt zal zijn en het systeem nog steeds stikstof gelimiteerd zal blijven maar dat de primaire productie wel zal toenemen als gevolg van extra stikstof die beschikbaar is. Ter illustratie, de gemodelleerde jaargemiddelden bij Dreischor van chlorofyl nemen toe van 5 naar $7 \mathrm{mg} / \mathrm{l}$ en primaire productie neemt toe van $250 \mathrm{gC} / \mathrm{m} 2 / \mathrm{j}$ naar (maximaal) $400-450 \mathrm{gC} / \mathrm{m} 2 / \mathrm{j}$. Het is dus de verwachting dat primaire productie fors toe zal nemen. In vergelijking met de Oosterschelde $(150-200 \mathrm{gC} / \mathrm{m} 2 / \mathrm{j})$ en lichtgelimiteerde Westerschelde $(100 \mathrm{gC} / \mathrm{m} 2 / \mathrm{j}$ in de stroom opwaartse delen en $150-200 \mathrm{gC} / \mathrm{m} 2 / \mathrm{j}$ richting de monding) is de primaire productie in het Grevelingenmeer hoog. Bij deze hoge verwachte primaire productie is het van belang in hoeverre het uitzakken van afgestorven algen de zuurstofvraag op de bodem gaat beïnvloeden. De resultaten van de modelstudie geven aan dat deze extra zuurstofvraag geen probleem zou moeten zijn i.v.m. toegenomen waterbeweging en aanvoer van zuurstofrijk water door verticale menging. De toename in primaire productie zal naar schatting (gemodelleerd) het doorzicht nauwelijks doen afnemen. In het model is echter geen rekening gehouden met import van zwevend stof vanuit de Voordelta.

\section{Resuspensie van slib}

In een zienswijze ingebracht door Prof. Filip Meysman wordt het volgende gesteld: als gevolg van sedimentatie van organisch rijk slib vanuit de Noordzee heeft zich een sliblaag opgebouwd tot enkele meters dik in de diepe westelijke geulen die dunner wordt naar het oosten toe. Door toelaten van getij wordt deze sliblaag gemobiliseerd en zal een zeer sterke vertroebeling optreden met in het ergste geval verslechtering van de waterkwaliteit (sterk vermindert doorzicht, hoge nutriënten concentraties en eutrofiëring en een grote zuurstofvraag met zuurstofloosheid als gevolg). Mogelijk blijft het slib langdurig in suspensie doordat het maar beperkt wordt afgevoerd. In de MER en de daaraan ten grondslag liggende onderzoeken is geen rekening gehouden met de rol van slib en mogelijke verslechtering van de waterkwaliteit in een getijde situatie.

Naar aanleiding van deze zienswijze heeft Deltares een aanvullende analyse en expertsessie uitgevoerd. Volgens de hydrodynamische modellen wordt de kritische stroomsnelheid voor resuspensie van slib bij $50 \mathrm{~cm}$ getij via de nieuwe doorlaat op weinig plekken in het Grevelingenmeer overschreden. Het water kan na ingebruikname van het doorlaatmiddel wel tijdelijk troebeler worden maar de verwachting is dat dit enkele weken duurt en niet langdurig zal zijn. Ook zal er geen zeer sterke vertroebeling optreden zoals in de zienswijze wordt gesteld. De conclusie dat het risico op langdurige vertroebeling van het systeem door opwerveling van bodemslib klein is, is later bevestigd door verschillende experts in een expertsessie bij Deltares. Dit onderwerp heeft de aandacht en wordt nog nader onderzocht. Het effect van stormen op resuspensie van slib is niet meetbaar vanuit beschikbare data wat er op duidt dat deze resuspensie beperkt is en/of van korte duur. Hoe dit precies zit blijft ook een aandachtspunt.

Doorwerking hogere primaire productie in het voedselweb

Het is de verwachting dat het Grevelingemeer zich gaat ontwikkelen in de richting van de Oosterschelde door toename getij, nutriënten, primaire productie etc.

\section{Bodemdieren}

De verwachting is dat er meer filterfeeders zullen ontwikkelen doordat er meer algen beschikbaar zijn door de aanwezige stroming en er meer waterbeweging zal zijn in een getijsituatie. Het is moeilijk te voorspellen hoe de fytoplanktonsoortensamenstelling er uit zal gaan zien. Dit hangt ook samen met de waterbeweging. In stilstaand water ontwikkelen over het algemeen kleinere algencellen die ook weer bepalend zijn voor ontwikkelen van zoöplanktonsoorten die weer bepalend zijn als voedsel voor vissen. Dit is lastig te voorspellen. De laatste jaren is de soortensamenstelling van het fytoplankton niet meer bepaald in het Grevelingenmeer. In het verleden (Bekkenrapportage 2011) zijn wel soortengroepen bepaald. De waterbeweging zal er ook voor zorgen dat het organisch materiaal meer wordt verspreid. Dit kan opgenomen worden door zoöplankton of het zakt uit naar het sediment waar het opgenomen wordt door bodemdieren. Schelpdieren zoals kokkel kunnen profiteren van getij door zich te vestigen op de intergetijdengebieden waar de predatie (door voornamelijk garnalen) lager zal zijn.

\section{Vissen}

De toename van benthische grazers kan ten koste gaan van het zoöplankton wat een belangrijke voedselbron is voor sommige vissoorten. Daarom is er geen reden om aan te nemen dat de visstand sterk zal toenemen bij invoering van getij. Daarnaast laat de huidige situatie zien dat soorten als haring en sprot niet verder het meer op willen trekken maar mogelijk wel bij toename van de water dynamiek. Mogelijk gebeurt dit wel bij toename van de dynamiek in een getijde situatie. Het Grevelingenmeer zal geen 'Eldorado' voor vissen en dus visetende vogels worden. De verschuiving van de toegenomen primaire productie zal naar verwachting vooral ten goede komen aan het benthos. Door het vergroten van de connectiviteit met de Noordzee, en nu al met de Oosterschelde, zullen er meer vissoorten naar 
het Grevelingenmeer komen. De connectiviteit is nu ook al redelijk dus de verwachting is niet dat dit voor een hogere visstand zal zorgen. Een saliniteitsgradiënt, door instroom van zoeter water vanuit het oosten, zou het Grevelingenmeer bijvoorbeeld wel veel aantrekkelijker maken voor vissen; maar daarvan is voorlopig geen sprake. Een toenemende intergetijdenzone is gunstig als kraamkamerfunctie met geschikt habitat voor bijvoorbeeld opgroeiende platvis. Echter is het ook niet de verwachting dat platvis sterk gaat toenemen vanwege de hierboven genoemde oorzaken.

\section{Visetende vogels}

In de huidige situatie foerageren de grote sterns die in het Grevelingenmeer broeden, niet op het Grevelingenmeer maar in de Voordelta. Dwergsterns en in mindere mate visdieven jagen wel op vis in de bovenste waterlaag van het Grevelingenmeer. Een mogelijke toename van haring en sprot in het Grevelingenmeer zou voor deze soorten gunstig zijn qua voedselvoorziening en omdat ze minder ver hoeven te vliegen vanaf hun broedplaats. Mogelijk dat ook de grote stern op het meer gaat foerageren.

In de huidige situatie is het Grevelingenmeer van betekenis voor visetende vogels alleen nemen hun aantallen al jarenlang af. In de Oosterschelde neemt het aantal visetende vogels de laatste jaren wel toe met name in de kom en noordelijke tak. Het gaat om wintergasten zoals geoorde futen en middelste zaagbekken. Deze toename komt mogelijk doordat het doorzicht verbeterd is. Ook de nationale schaal is hierbij van belang. Als in een bekken het voedselaanbod afneemt, gaan soorten op zoek naar betere foerageergebieden en kunnen zij zich tijdelijk of soms ook blijvend naar elders verplaatsen. Het kan ook zo zijn dat visetende vogels het Grevelingemeer als slaap- en rustplaats gebruiken en naar de Oosterschelde trekken om er te foerageren. De aalscholvers zijn geen zichtjagers en blijven redelijk stabiel. Wat betreft de hogere trofische niveaus, zowel vogels als vissen, is het koffiedik kijken welke veranderingen gaan plaatsvinden. Vooral ook omdat het onduidelijk is welke laag-trofische veranderingen er gaan plaatsvinden in het meer zoals hierboven gesteld.

\section{Ontwikkeling van intergetijdengebieden bij getij}

\section{Onzekerheden oeverprofiel}

Door de onzekerheid van het bodemprofiel tussen - 0,20 meter NAP en -1,5 meter NAP kan niet het exacte areaal van (tijdelijk) intergetijdengebied en ondiep water worden bepaald. De inschatting is dat het areaal intergetijdengebieden in de gemodelleerde resultaten onderschat is en dat de oevers in werkelijkheid een flauwer verloop en daarmee grotere oppervlakte zullen bevatten. Paul Paulus geeft aan dat in 2018 deze zone wordt ingemeten. Mogelijk kunnen de kaarten in een later stadium nog worden geupdate.

\section{Erosie}

Marijn geeft een korte toelichting van de studie van De Jong \& Van Maldegem (2010) waarin de te verwachte erosie is ingeschat bij verschillende getijslagen. De opbouwende krachten bij $50 \mathrm{~cm}$ getij zullen verwaarloosbaar zijn ( $10 \%$ van de oorspronkelijke getijslag). In een getijdesituatie zal de golfaanval variëren tussen hoog- en laagwater. De verwachting is dat de erosie met dezelfde snelheid door zal gaan als in de huidige situatie met een stagnant peil. In 40 jaar tijd is een oppervlakte van 240 ha geërodeerd. Alphons: logischerwijs ging de erosie na afsluiting sneller en daarna geleidelijker. Het type oever (onverdedigd, direct/indirect of gecombineerd verdedigd) is bepalend voor het type intergetijdengebied dat zal ontstaan: hard of zacht substraat. En daarnaast ook van invloed op de erosie of de reductie van erosie. De indirecte oevervededigingen zorgen voor een luwe zone intergetijdengebied. Volgens de studie is de verwachting dat ook dit gebied geleidelijk zal eroderen maar volgens Alphons van Winden kan mogelijk ook sediment juist goed bezinken in de luwte achter de dam. Als er een waterbeweging is vanuit een dynamisch gebied (hier het open water) naar een rustig gebied (hier het gebied achter de dammen) dan zal het sediment dat het water bevat eerder bezinken in het rustige water, zodat daar netto sedimentatie plaats vindt. In de niet met indirecte oeververdedigingen versterkte kuststroken gaat dit niet, omdat er daar op korte afstands geen groot verschil in dynamisch en rustig water is.

\section{Rijshouten dammen}

Op termijn zullen de oeververdedigingen vervangen moeten worden. Het voordeel van gebruik van rijshouten dammetjes, zoals ook wordt toegepast in het Waddengebied, is dat ze de golven dempen maar dat het water met sediment erdoorheen kan stromen en dat ze kunnen fungeren als sedimentvang. 


\section{Ontwikkeling benthos}

De vraag die is gesteld door o.a. de Vogelbescherming is de verwachtte ontwikkeling van het bodemleven in de nieuwe intergetijdengebieden en potentie voor foeragerende vogels. De vrees was dat de intergetijdengebieden wellicht te zandig zouden zijn en er geen rijk bodemleven tot ontwikkeling zou kunnen komen. De verwachting is echter dat de intergetijdengebieden qua bodemleven vergelijkbaar zullen zijn met de Oosterschelde. Het Grevelingenmeer is net als de Oosterschelde een zandig systeem. Toch is dit geen beperking voor bodemleven. Vergelijkende studies tussen de Oosterschelde en de, meer slibrijke, Westerschelde laten zien dat sommige soorten bodemdieren daadwerkelijk gebonden zijn aan een hoger slibgehalte maar dat de meeste soorten in de Oosterschelde voorkomen bij veel zandigere bodems dan in de Westerschelde. De verklaring hiervoor is dat het niet het slibgehalte is wat bepalend is voor het voorkomen van soorten maar de factoren die daar mee correleren zoals stroomsnelheid. Een zandige bodem kan dus nog steeds van betekenis zijn voor foeragerende vogels. De Oosterschelde is hier een voorbeeld van. Ook op de suppleties die in de Oosterschelde zijn uitgevoerd met grof zand (zonder slib) ontwikkelen kokkels, nonnetje etc. Er zijn gespecialiseerde soorten die gebonden zijn aan slib, maar de meeste soorten hebben een brede tolerantie in relatie tot sedimentsamenstelling. De combinatie van andere factoren zoals stroomsnelheid, droogvalduur, voedsel spelen hier natuurlijk ook een belangrijke rol.

Mogelijk neemt het slib gehalte in het Grevelingenmeer iets toe door aanvoer vanuit de Noordzee of blijft het gelijk. Ook kan er vanuit de ondiepere geulen, waar zich sinds de afsluiting slib heeft opgehoopt en waar de stroomsnelheid a.g.v. het getij voldoende toeneemt, slib opwervelen. De verwachting is in ieder geval niet dat het slibgehalte in het water gaat afnemen.

Algehele verwachting is dat biomassa en diversiteit van bodemdieren zal toenemen en dat dit gunstig zal zijn voor foeragerende vogels.

Indirect verdedigde oevers: dit zijn nu al interessante gebieden voor steltlopers die foerageren in ondiep water en op droogvallende delen achter de dammetjes. In de toekomst zal hier ook potentieel interessant intergetijdengebied ontstaan met zeer beperkte golfwerking. Ook zal organisch materiaal in deze lagunes makkelijker sedimenteren wat weer voedsel oplevert voor bodemdieren.

Het Grevelingenmeer blijkt nu al een gunstig gebied als hoogwatervluchtplaats te zijn voor overtijende steltlopers uit de Oosterschelde. Dit komt waarschijnlijk doordat er in het Grevelingenmeer minder verstoring is. In de Oosterschelde staan deze HVP's onder druk door toenemende verstoring. In de nieuwe situatie zijn eb en vloed in het Grevelingen precies uit fase met de Noordzee en Oosterschelde. In het Grevelingenmeer zal de getijcyclus drie uur achter lopen op dat van de Noordzee. De functies van de HVP's zal hierdoor niet onder druk komen te staan. Ook biedt dit faseverschil interessante kansen voor foeragerende vogels. Als op de Noordzee en de Oosterschelde het tij gekenterd is en weer hoog water wordt is het op het Grevelingenmeer het water nog aan het zakken naar laagwater en hebben vogels langer de tijd om te foerageren. Tegelijkertijd, als het op het Grevelingenmeer hoog water wordt zal het daarbuiten al weer binnen een paar uur eb worden. Dus ook al zal het oppervlakte intergetijdengebied van beperkte omvang zijn in vergelijking tot de Ooster- en Westerschelde biedt het mogelijkheid tot foerageren op momenten dat het elders hoog water is in een relatief onverstoorde omgeving in vergelijking met de Oosterschelde.

\section{Peil regulatie, windopzet en zeespiegelstijging}

Bij Dreischor (Bommenede) staat een meetpaal die de waterstanden meet. Het voornemen is om in de toekomst ook in het oosten een meetpaal te plaatsen om aan weerzijden van het meer de waterstanden in de gaten te houden zodat hierop geanticipeerd en gestuurd kan worden.

Het nieuwe doorlaatmiddel (15 kokers) biedt mogelijkheid tot vrij nauwkeurige fijnafregeling van de waterstand in combinatie met de Brouwers- en Flakkeese Spuisluis. Peilregulatie is nodig omdat het middenpeil in het Grevelingenmeer $(-0,20$ meter NAP) lager is dan op de Noordzee. Dit lagere middenpeil is wenselijk vanuit natuur en landbouw. Op een termijn van 20-30 jaar zal, afhankelijk van de zeespiegelstijging en dimensionering van het doorlaatmiddel, dit middenpeil niet meer houdbaar zijn omdat het afwatervenster te klein wordt. Bij een bij de huidige omstandigheden passend doorlaatmiddel zal na 30 centimeter zeespiegelstijging het middenpeil waarschijnlijk omhoog moeten. Bij gebruik van een robuuster doorlaatmiddel of getijcentrale kan correctie van het middenpeil langer uitgesteld worden. Als storm wordt verwacht met windopzet als gevolg kan het peil al van tevoren al wat lager worden gezet. Dit is dan vooral in de zomer wenselijk; want in de winter is het juist te verkiezen om het water 
enkele malen extra hoog te laten komen. Door te knijpen of extra open te zetten is veel mogelijk. De komende jaren kan in overleg het peilregime worden bepaald binnen de mogelijkheden die het nieuwe doorlaatmiddel biedt. Vanuit natuurwaarden is het toelaten van windopzet wenselijk. Deze incidentele overspoeling van de oevers is ook van belang voor natuurwaarden (tegengaan successie).

Gunstig voor foeragerende vogels is een geleidelijk afgaand getij zodat ze al foeragerend de waterlijn kunnen volgen (vloed dominant getij, snel op en langzaam af). In een klein laagje water zijn bodemdieren vaak nog actief en makkelijker te vangen door vogels. Zodra het slik droogvalt trekken bodemdieren zich terug. Een vraag is nog wat de haalbaarheid is in relatie tot het "ebvenster" (de tijd dat het water naar de Noordzee kan lopen) met het nieuwe doorlaatmiddel.

\section{Winter intergetijdengebied}

Het deel van het intergetijdengebied dat een half jaar lang droog valt in de zomer is ongunstig voor bodemdieren. In de periode dat het droogvalt zullen ze hier afsterven. Voor broedvogels en vegetatie is dit echter gunstig. Deze zone hoeft zeker geen $30 \mathrm{~cm}$ verschil te zijn met het zomerpeil zoals in het scenario. Een incidentele opzet in de winter is wel gunstig en dit is met het doorlaatmiddel te sturen.

Op het moment dat deze zone droogvalt bij instelling van het zomerpeil in het voorjaar is deze zone tijdelijk echter zeer gunstig omdat vogels de bodemdieren kunnen opeten zonder dat het hoogwater wordt.

\section{Planuitwerkingsfase en onderzoek}

Voor beter inzicht in de ecologische relaties is onderzoek nodig. Onderzoek gericht op zoöplankton en vissen zal meer inzicht geven in de gevolgen voor vogels. Steeds strandt de discussie omdat dit onbekend is.

Paul Paulus geeft de planning aan. Als het nieuwe kabinet akkoord gaat met het voorkeursalternatief en er wordt geld vrij gemaakt dan is 2018 een voorbereidingsjaar en zal in 2019 de aanbesteding plaatsvinden en kan in 2020 worden begonnen met de planuitwerkingsfase. Dit is een periode van 2-3 jaar waarin je samen nog naar optimalisatie kan zoeken. In 2023 zou op zijn vroegst de realisatie kunnen starten. Voor die tijd is er dus nog veel ruimte voor onderzoek en optimalisatie. Daarnaast, geeft Paul aan, zijn er kansen om op kleine schaal te experimenteren nu de Flakkeese Spuisluis operationeel is. Je zou bijvoorbeeld de effecten van een klein getij van $10 \mathrm{~cm}$ kunnen testen om bijvoorbeeld te experimenteren met peilbeheer. Het huidige peilbesluit biedt hier de ruimte voor. Hier zouden we mijn zijn allen over na te kunnen denken. Dit moet goed georganiseerd worden en hier hoort ook omgevingsmanagement bij.

Peter Herman stelt voor om een intensief meetjaar te plannen. Hoe meer je tegelijk meet, hoe groter de meerwaarde van iedere meting afzonderlijk. Zo kun je elke meting in een groter verband plaatsen en causale verbanden onderzoeken van zaken die nu onzeker zijn en het gissen is naar een verklaring zoals bijvoorbeeld de rol van het zoöplankton in relatie tot vissen en vogels. Dit zou een excercitie van meerdere kennisinstellingen en universiteiten kunnen zijn. Dan zou je echt een stap vooruit kunnen maken.

Dit zou mooi gekoppeld kunnen worden aan de uitvoering vanuit een watersysteemrapportage (2018?) waarin deze de kennis van de huidige situatie zichtbaar wordt en de kennislancunes die er zijn. Een intensief meetjaar (2019?) zou hier mooi op aan kunnen sluiten. Daarnaast zou je ook al kunnen starten zodat je meerdere meetjaren kunt afdekken.

\section{Kennisvragen}

Huidige situatie

- Hoe ziet de soortensamenstelling en biomassa van het fytoplankton er uit en wat leert dit ons over de waterkwaliteit?

- Hoe groot zijn de huidige schelpdierbestanden (natuurlijk en kweek)?

- Hoe werkt de primaire productie door naar andere soortengroepen voor soortensamenstelling en biomassa: zoöplankton, bodemdieren en in het bijzonder schelpdieren, vissen en vogels? 
- Hoe ziet de soortensamenstelling en biomassa van het zoöplankton er uit en wat leert dit ons over aan-/afwezigheid en biomassa van vissoorten?

- Hoe hebben bodemdieren (soorten en biomassa) zich ontwikkeld in de afgelopen jaren en wat leert dit ons over het watersysteem?

- Waarom concentreert de (pelagische en juveniele, vnl. haring en sprot) visbiomassa zich voornamelijk in het westen van het Grevelingenmeer en trekken deze vissen niet verder het meer op?

- Waarom gaan aantallen visetende vogels achteruit?

\section{Toekomstige situatie}

- Welke soortensamenstelling en biomassa van fytoplankton kan worden verwacht bij invoering van getij? Ontstaat er ook een vergrootte kans op bloei van schadelijke algen (bv. Phaeocystis)?

- Hoe werkt de verwachte toename in primaire productie door naar andere soortengroepen voor soortensamenstelling en biomassa: zoöplankton, bodemdieren, vissen en vogels?

- Wat wordt verwacht van de (snelheid van) ontwikkeling van bodemdieren (soorten en biomassa) in de toekomstige intergetijdengebeiden op basis van beschikbare kennis en welke vogelsoorten kunnen hiervan profiteren?

\section{Aanbevelingen}

- Om inzicht te krijgen in ontwikkeling van het bodemleven in de laatste jaren (in relatie tot voorgaande ontwikkeling) na de laatste bekkenrapportage (2011) kunnen MWTL bemonsteringsgegevens van het bodemleven worden geanalyseerd.

- Uitvoeren van een 'intensief meetjaar' waarin gelijktijdig, een zeer breed aantal parameters en soortengroepen worden gemonitord om grip te krijgen op bovenstaande vragen en causale verbanden te kunnen onderzoeken. Dit kan gecombineerd worden met een T0 monitoring. 


\section{H. Aantekeningen interview experts Bureau Waardenburg}

\section{Aantekeningen interview deskundigen \\ van Bureau Waardenburg t.b.v. \\ Scenariostudie natuurperspectief \\ Grevelingenmeer}

Overleg via Skype

DATUM

Maandag 15 januari 2018

TIJDSTIP

$10: 30-12: 00$

Geïnterviewden van Bureau Waardenburg:

Karin Didderen

Wouter Lengkeek

Interviewer van Wageningen Marine Research: Marijn Tangelder

Onderstaand wordt een beknopte samenvatting gegeven van wat door beide experts naar voren is gebracht.

\section{Zuurstofhuishouding in relatie tot bodemleven}

Onderzoek afgelopen jaren

In 2007 is een eerste studie uitgevoerd naar het bodemleven en toen is voor het eerst het voorkomen van 'schimmelmatten' (later bleek dat het om de bacterie Beggiatoa ging) en sterfte van het bodemleven tot op 5 meter diepte. Dit sterfte van het bodemleven werd bevestigd door geluiden vanuit sportduikers. Daarna is meer diepgaand onderzoek uitgevoerd om het voorkomen van bacteriematten en schade aan het bodemleven in kaart te brengen d.m.v. visuele inspectie. Daarna is in de winter gekeken in welke mate herstel optrad en is in de daarop volgende zomers gemonitord.

\section{Ontwikkeling bacteriematten}

Uit de monitoring komt naar voren dat de weersomstandigheden (temperatuur en wind, soms speelt zout stratificatie een rol) voorafgaand aan de bemonstering zeer bepalend zijn voor het voorkomen van bacterie matten. De matten ontwikkelen niet als het volledig zuurstofloos is want de bacterie heeft zuurstof nodig. De matten komen alleen voor op het moment dat het zuurstofloos begint te worden, of als de zuurstofconcentratie in het water net weer gaat stijgen. Daardoor is het voorkomen van bacteriematten geen directe indicator voor zuurstofloosheid omdat ze pas na zuurstofloosheid wanneer er weer zuurstof in de waterlaag zit aan het bodem oppervlak voorkomen. Het gaat dus om een tijdelijke situatie waarin zuurstofconcentratie een rol speelt. De bacteriematten ontwikkelen aan het bodemoppervlak na een periode van zuurstofloosheid. Doordat de bacterie zelf zuurstof consumeert daalt de zuurstof concentratie (en concurreren ze met het bodemleven om zuurstof) en kan de bedekking weer afnemen afhankelijk van de weersomstandigheden, bv na een storm kan weer mening optreden. Het onderzoek uit 2013 (Didderen et al.) beschrijft het voorkomen van bacteriematten en schade aan het bodemleven op 100 'probleemlocaties' in het Grevelingenmeer. De matten komen op alle diepten voor en vertonen de grootste bedekking in de bocht van St Jakob (vrij ondiep) en bij het Springersdiep. Vanuit de modellering door Deltares komt naar voren dat langere perioden van zuurstofloosheid $(>7$ dagen) vooral optreedt in de diepe geulen en niet zozeer op de eerder genoemde plekken. Dit komt doordat zowel de zuurstofloosheid als het voorkomen van de bacteriematten wordt beïnvloed door hoe organisch materiaal bezinkt. Bijvoorbeeld door Zeesla of kleinere algen die ophopen in deze delen van het meer, afsterven en bezinken naar de bodem. Daardoor ontstaat een organische belasting met een zuurstofvraag die meestal plaatsvindt in de zomer bij hoge temperaturen. Dit versneld het proces van zuurstof consumptie en ontwikkelen van bacteriematten. Doordat deze ecologische processen niet in het model zitten maar wel zeer bepalend zijn, laat het model een te sober beeld zien van de werkelijkheid. Het is van belang om de resultaten van de modelstudies niet te leidend te laten zijn in de discussie. Anderzijds zijn in eerdere studies de modelresultaten wel gebruikt als basis om ecologische veranderingen te voorspellen. Dit is een moeilijk punt dus.

Relatie schade bodemleven

De relatie tussen het voorkomen van bacteriematten en schade aan het bodemleven is significant en is te verklaren door de concurrentie om zuurstof. Beggiatoa komt van nature voor in alle marien 
sedimenten, alleen normaal op een aantal centimeter diepte in het sediment (de zogenaamde redoxlaag). Beggiatoa matvorming verergert en verlengt de zuurstofloosheid (de bacterie consumeert immers zuurstof waardoor de zuurstofloosheid), maar de hoofdreden dat herstel zolang duurt is vooral na een episode dat alle infauna is gestikt: door het ontbreken van bioturbatie blijft de situatie dan lang ongustig en kan zuurstof niet goed in het sediment dringen. Dit is dus niet door de fysieke barriere van de mat, meer door de zuurstof condities in het sediment na sterfte van infauna. Gestorven dieren dragen overigens ook bij aan de zuurstofvraag.

\section{Referentie situaties}

Europees gezien is er consensus over dat het optreden van zuurstofloze condities en in diepe delen van brakke en zoute stagnante systemen een natuurlijk proces is zoals in de Oostzee, Camargue in Frankrijk en de fjorden in Noorwegen en Denemarken. De zeer kunstmatige toestand van het Grevelingenmeer laat zich echter moeilijk vergelijken (afgedamd estuarium). Een voorbeeld van een afgedamd systeem is het brak stagnante Oostvoornse meer. Daar is geen stratificatie. Recent treedt er ontwikkeling van blauwalgen op doordat de komst van een exotische grondel de grazende slakkensoorten op eet en er sprake is van een grote nalevering van fosfaat in ondiepe delen van het meer. Voor het Grevelingenmeer is er niet een referentie situatie van een stagnant zout, kunstmatig meer. Mogelijk dat het meer best aardig functioneert, dat weten we niet zo goed. Feit is wel dat als de zuurstofproblematiek wordt opgelost het systeem meer gaat lijken op de situatie zoals het was voor de afdamming en meer op de oostzijde van de Oosterschelde.

Voor de monitoring is uitgegaan van het gebied ten zuiden van de Hompelvoet als referentie gebied. Dit is het grootste stuk open water georiënteerd op westen wind (weinig zuurstofloosheid, veel bodemleven) en ook de Oosterschelde waar eigenlijk nooit zuurstofloze condities optreden. Daar komen ook tot op 20 meter diepte verschillende diersoorten voor zoals (slib)anemonen, schelpdieren en wormen. De Zeeanjelier (en anemonen in het algemeen) is een goede indicatorsoort voor goede zuurstofcondities met voldoende waterbeweging. Aanwezigheid van wormenhoopjes laten ook goed het voorkomen van wormen in de bodem zien, mosselen komen ook alleen voor in condities met voldoende zuurstof.

\section{Flakkeese Spuis/uis}

In 2016 is een T0 meting uitgevoerd. In de zomer van 2017 (na opening) is opnieuw een inventarisatie uitgevoerd en is een duidelijke verbetering te zien: de bedekking met matten is lager dan ooit gemeten in de zomer. Echter voor de sluis op 14 meter diepte is de bedekking van de bacteriematten het grootst. Dit komt waarschijnlijk doordat het daar lange tijd zuurstofloos is geweest en door de betere menging is er nu wel zuurstof beschikbaar waardoor de matten ontwikkelen. Dit laat zien dat je niet altijd precies kunt voorspellen wat er gaat gebeuren. Verder is een enorme aangroei van mosselen te zien en toename in voorkomen van vissen, zoals harders, kornaarsvis en tweevlekgrondel. Er is een duidelijke positieve ecologische verandering gaande.

\section{Autonome ontwikkeling en verandering systeem met getij}

Bij gelijkblijvend de temperaturen zal het probleem niet zozeer verergeren. Als het een week lang 30 graden is treedt er grote sterfte op van het bodemleven maar ook vissen en kwallen. Dit is een groot ecologisch probleem veroorzaakt door de afdamming. Als er vaker warme perioden optreden (cf klimaatverandering) wordt het probleem erger. Echter zijn er hoge verwachtingen van de betekenis van de Flakkeese spuisluis voor de ecologische situatie. Flakkeese spuisluis is een kans voor waterbeheer om zuurstofloosheid te managen. Het grootste probleem is de zuurstofloosheid in de ondiepe delen en ondiepe bodem. Het is van belang om eerst eens goed te monitoren welke kwaliteitsverbetering dit voor het systeem kan betekenen.

Introductie van gedempt getij zal het systeem robuuster maken. Echter gaat het om een zeer gestuurd getij en wordt het niet zoals een natuurlijk proces met slib, plankton en de bijbehorende productiviteit maar meer een waterverversing. Dat is een zorg. Een zorg is vooral ook de getijcentrale, daar verwachten we onmitigeerbare negatieve effecten voor natuurwaarden en voornamelijk voor vissen. Veel vissoorten migreren vaak heen en weer en dan is bijvoorbeeld een norm van $1 \%$ sterfte ontzettend veel. Dit kan erg nadelig zijn voor bijvoorbeeld makrelen, haring en de zeebaarzen. Als je met de Flakkeese Spuisluis ook een aanzienlijk kwaliteitsverbetering kan betekenen verdient dat eerst de aandacht. Ook is het een hele mooie manier om meer te leren over hoe een doorlaat in de Brouwersdam gaat doorwerken in het systeem.

In de expertsessie is gezegd dat toename van nutriënten gaat leiden tot meer groei van algen. Dit kan maar is soms ingewikkelder. De schelpdieren in het meer zullen toenemen, de filterfeeders gaan groeien en meer filterfeeders. De algen in de waterkolom zullen dan niet toenemen. De vraag is ook wat er gaat gebeuren met de opgeslagen nutriënten in het systeem zoals de nalevering van fosfor maar ook hoe stikstof en silicium gaan ontwikkelen (kennislancune).

Haring en Sprot zullen profiteren van de toename in water beweging en over het gehele Grevelingenmeer voor kunnen komen zoals ook in de Oosterschelde waar ze ook bij Bruinisse 
voorkomen. De vraag is hoe de zoöplankton zich gaat ontwikkelen. Jonge platvissen zijn ook afhankelijk van benthische algen en o.a. wormen. De verwachting is dat benthische algen straks beter kunnen ontwikkelen door verbeterde zuurstofcondities en hier zal (vooral jonge) platvissen van profiteren (kinderkamer functie). Vaker voorkomen van tweevlekgrondel (zeer talrijk de afgelopen jaren) is interessant voor visetende vogels echter is nog weinig bekend over deze soort.

In de expertsessie is naar voren gebracht dat de verwachting is dat een rijk bodemleven zal ontwikkelen. Dit wordt ondersteund. 


\section{Doelstellingen Natura 2000 Grevelingenmeer}

Onderstaande doelstellingen voor het Grevelingenmeer komen uit het aanwijzingsbesluit (Programmadirectie Natura 2000 2013).

\begin{tabular}{|c|c|c|c|c|}
\hline Habitattypen & LSI & Doel opp. & Doel kwal. & Kernopg. \\
\hline H1310A - Zilte pionierbegroeiingen (zeekraal) & - & $=$ & $=$ & \\
\hline H1310B - Zilte pionierbegroeiingen (zeevetmuur) & + & $=$ & $=$ & \\
\hline H1330B - Schorren en zilte graslanden (binnendijks) & - & $=$ & $=$ & \\
\hline H2130B - *Grijze duinen (kalkarm) & -- & $=$ & $=$ & \\
\hline H2160 - Duindoornstruwelen & + & $=$ & $=$ & \\
\hline H2170 - Kruipwilgstruwelen & + & $=$ & $=$ & $1.15, \mathrm{~W}$ \\
\hline H2190B - Vochtige duinvalleien (kalkrijk) & - & $=$ & $=$ & $1.15, \mathrm{~W}$ \\
\hline H6430B - Ruigten en zomen (harig wilgenroosje) & - & $=$ & $=$ & \\
\hline
\end{tabular}

\begin{tabular}{|l|l|l|l|l|l||}
\hline Habitatsoorten & LSI & Doel omvang leefgeb. & Doel kwal. leefgeb. & Doel pop. & Kernopg. \\
\hline H1340 - *Noordse woelmuis & -- & $>$ & $>$ & $>$ & 1.14 \\
\hline H1903 - Groenknolorchis & -- & $=$ & $=$ & $=$ & $1.15, \mathrm{~W}$ \\
\hline \hline
\end{tabular}

\begin{tabular}{|c|c|c|c|c|c|}
\hline Broedvogelsoorten & LSI & Doel omvang leefgeb. & Doel kwal. leefgeb. & Omvang pop. & Kernopg. \\
\hline A081 - Bruine Kiekendief & + & $=$ & $=$ & 17 & \\
\hline A132 - Kluut & - & $>$ & $>$ & $2000 *$ & 1.13 \\
\hline A137 - Bontbekplevier & -- & $>$ & $>$ & $105 *$ & 1.13 \\
\hline A138 - Strandplevier & -- & $>$ & $>$ & $220 *$ & 1.13 \\
\hline A191 - Grote stern & -- & $=$ & $=$ & $6200 *$ & 1.13 \\
\hline A193 - Visdief & - & $>$ & $>$ & $6500 *$ & 1.13 \\
\hline A195 - Dwergstern & -- & $=$ & $=$ & $300 *$ & 1.13 \\
\hline
\end{tabular}

\section{Habitattypen}

Doelstelling voor oppervlakte en/of kwaliteit

$=$ behoud

$>\quad$ uitbreiding

$=(>)$ uitbreiding met behoud van de goed ontwikkelde locaties

$<\quad$ vermindering is toegestaan, ten gunste van met name genoemde habitattype

$=(<)$ achteruitgang ten gunste van ander habitattype toegestaan

$>(<)$ oppervlak staat in principe op uitbreiding, maar mag achteruit gaan ten gunste van ander habitattype
Habitattype, soorten, broedvogels en niet-broedvogels

Landelijke staat van instandhouding

$+\quad$ gunstig

matig gunstig

zeer ongunstig

Relatieve bijdrage van het gebied in Nederland

$++\quad \operatorname{groot}(>15 \%)$

$+\quad$ gemiddeld $(2-15 \%)$

Soorten, broedvogels, niet-broedvogels

Doelstelling voor leefgebied en/of omvang populatie

$=$ behoud

$>\quad$ uitbreiding/verbetering

$<\quad$ vermindering is toegestaan

$=(<)$ achteruitgang ten gunste van andere soort toegestaan

\section{Broedvogels}

Relatieve bijdrage van het gebied aan de Nederlandse populatie

$0<2 \%$

$+\quad 2-15 \%$

$++15-50 \%$

$+++>50 \%$ 


\begin{tabular}{|c|c|c|c|c|c|c|c|}
\hline \multicolumn{2}{|c|}{ Niet-broedvogels } & LSI & Doel omvang leefgeb. [ & \multicolumn{2}{|c|}{ Doel kwal. leefgeb. } & Omvang pop. & Kern opg. \\
\hline \multicolumn{2}{|c|}{ A004 - Dodaars } & + & $=$ & \multicolumn{2}{|c|}{$=$} & 70 & \\
\hline \multicolumn{2}{|c|}{ A005 - Fuut } & - & $=$ & \multicolumn{2}{|c|}{$=$} & 1600 & $1.04, \mathrm{~W}$ \\
\hline \multicolumn{2}{|c|}{ A007-Kuifduiker } & + & $=$ & \multicolumn{2}{|c|}{$=$} & 20 & \\
\hline \multicolumn{2}{|c|}{ A008-Geoorde fuut } & - & $=$ & \multicolumn{2}{|c|}{$=$} & 1500 & $1.04, W$ \\
\hline \multicolumn{2}{|c|}{ A017 - Aalscholver } & + & $=$ & \multicolumn{2}{|c|}{$=$} & 310 & \\
\hline \multicolumn{2}{|c|}{ A026 - Kleine Zilverreiger } & + & $=$ & \multicolumn{2}{|c|}{$=$} & 50 & \\
\hline \multicolumn{2}{|c|}{ A034 - Lepelaar } & + & $=$ & \multicolumn{2}{|c|}{$=$} & 70 & \\
\hline \multicolumn{2}{|c|}{ A037 - Kleine Zwaan } & - & $=$ & \multicolumn{2}{|c|}{$=$} & 4 & \\
\hline \multicolumn{2}{|c|}{ A041 - Kolgans } & + & $=$ & \multicolumn{2}{|c|}{$=$} & 140 & \\
\hline \multicolumn{2}{|c|}{ A043 - Grauwe Gans } & + & $=$ & \multicolumn{2}{|l|}{$=$} & 630 & \\
\hline $\mathrm{A04}$ & 5 - Brandgans & + & $=$ & $=$ & & 1900 & \\
\hline A04 & 6 - Rotgans & + & $=$ & $=$ & & 1700 & \\
\hline$\underline{\mathrm{AO4}}$ & 8 - Bergeend & + & $=$ & $=$ & & 700 & \\
\hline A05 & $0-$ Smient & + & $=$ & $=$ & & 4500 & \\
\hline A05 & 1 - Krakeend & + & $=$ & $=$ & & 320 & \\
\hline $\mathrm{A05}$ & 2 - Wintertaling & - & $=$ & $=$ & & 510 & \\
\hline A05 & 3 - Wilde eend & + & $=$ & $=$ & & 2900 & \\
\hline A05 & 4 - Pijlstaart & - & $=$ & $=$ & & 60 & \\
\hline$\underline{\mathrm{A} 05}$ & 6 - Slobeend & + & $=$ & $=$ & & 50 & \\
\hline$\underline{\mathrm{A} 06}$ & 7 - Brilduiker & + & $=$ & $=$ & & 620 & \\
\hline A06 & 9 - Middelste Zaagbek & + & $=$ & $=$ & & 1900 & $1.04, W$ \\
\hline$\underline{\mathrm{A} 10}$ & 3 - Slechtvalk & + & $=$ & $=$ & & 10 & \\
\hline A12 & 5 - Meerkoet & + & $=$ & $=$ & & 2000 & \\
\hline$\underline{\mathrm{A} 13}$ & 0 - Scholekster & -- & $=$ & $=$ & & 560 & \\
\hline $\mathrm{A13}$ & 2 - Kluut & - & $=$ & $=$ & & 80 & 1.13 \\
\hline $\mathrm{A} 13$ & 7 - Bontbekplevier & + & $=$ & $=$ & & 50 & 1.13 \\
\hline A13 & 8 - Strandplevier & -- & $=$ & $=$ & & 20 & 1.13 \\
\hline A14 & 0 - Goudplevier & -- & $=$ & $=$ & & 2600 & \\
\hline A14 & 1 - Zilverplevier & + & $=$ & $=$ & & 130 & \\
\hline A14 & 9 - Bonte strandloper & + & $=$ & $=$ & & 650 & \\
\hline A15 & 7 - Rosse grutto & + & $=$ & $=$ & & 30 & \\
\hline A16 & $0-$ Wulp & + & $=$ & $=$ & & 440 & \\
\hline A16 & 2 - Tureluur & - & $=$ & $=$ & & 170 & \\
\hline A16 & 9 - Steenloper & -- & $=$ & $=$ & & 30 & \\
\hline Kern & opgaven & & & Niet- & broedvogels & & \\
\hline w & wateropgave & & & Relati & ve bijdrage van $h$ & let gebied aan de Nede & lerlandse populatie \\
\hline 4 & sense of urgency: beheeropgave & & & - & $0-2 \%$ & & \\
\hline 4 & sense of urgency opgave m.b.t. $v$ & waterco & ondities & + & $2-15 \%$ & & \\
\hline & & & & ++ & $15-50 \%$ & & \\
\hline 1.04 & Behoud foerageerfunctie viseten & de voge & els in het bijzonder voor fuut A005, & +++ & $50-100 \%$ & & \\
\hline & & & & $x$ & onvoldoende dat & & \\
\hline 1.13 & $\begin{array}{l}\text { Behoud ongestoorde rustplaatsen } \\
\text { (waaronder embryonale duinen }\end{array}$ & $\begin{array}{l}n \text { en op } \\
+2110)\end{array}$ & $\begin{array}{l}\text { timaal voortplantingshabitat } \\
\text { voor bontbekplevier A137, }\end{array}$ & s & betreft slaapplaa & tsfuncties & \\
\hline & $\begin{array}{l}\text { strandplevier A138, kluut A132, } \\
\text { visdief A193 en grijze zeehond }\end{array}$ & & tern A191 en dwergstern A195, & (s) & betreft nachtelijk & ke slaapplaatsen & \\
\hline 1.14 & $\begin{array}{l}\text { Behoud van geìsoleerde eilanden } \\
\text { * } 1340 \text { (onbereikbaar voor conc }\end{array}$ & als lee & $\begin{array}{l}\text { efgebied voor noordse woelmuis } \\
\text { en). }\end{array}$ & $f$ & $\begin{array}{l}\text { betreft foerageer } \\
\text { monitoringsgege }\end{array}$ & $\begin{array}{l}\text { Ifuncties op grond van } \\
\text { evens }\end{array}$ & $\mathrm{n}$ andere dan de reguliere \\
\hline 1.15 & $\begin{array}{l}\text { Behoud platen Grevelingen met I } \\
\text { (kalkrijk) H2190_B, grijze duinen } \\
\text { groenknolorchis H1903. }\end{array}$ & $\begin{array}{l}\text { lage be } \\
n * H 21\end{array}$ & $\begin{array}{l}\text { groeiingen van vochtige duinvalleien } \\
\text { 30, kruipwilgstruwelen } \mathrm{H} 2170 \text { en }\end{array}$ & en & $\begin{array}{l}\text { voor een naam } b \\
\text { achter een getal } \\
\text { doel }\end{array}$ & $\begin{array}{l}\text { petekend het prioritair } \\
\text { in de kolom omvang } \mathrm{p}\end{array}$ & $\begin{array}{l}\text { re soort of habitattype; } \\
\text { populatie duidt het op een regionaal }\end{array}$ \\
\hline
\end{tabular}

\section{Kernopgaven}

1.04 Foerageerfunctie visetende vogels: Behoud foerageerfunctie visetende vogels in het bijzonder voor fuut A005, geoorde fuut A008 en middelste zaagbek A069.

1.13 Voortplantingshabitat: Behoud ongestoorde rustplaatsen en optimaal voortplantingshabitat (waaronder embryonale duinen H2110) voor bontbekplevierA137, strandplevier A138, kluut A132, grote stern A191 en dwergstern A195, visdief

A193 en grijze zeehond H1364.

1.14 Leefgebied noordse woelmuis: Behoud van geïsoleerde eilanden als leefgebied voor noordse woelmuis *H1340 (onbereikbaar voor concurrenten).

1.15 Lage begroeiingen: Behoud platen Grevelingen met lage begroeiingen van vochtige duinvalleien (kalkrijk) H2190_B, grijze duinen *H2130, kruipwilgstruwelen $\mathrm{H} 2170$ en groenknolorchis $\mathrm{H} 1903$. 


\section{J. Doelen van de Kaderrichtlijn Water}

Samenvatting Goed Ecologische Potentieel (GEP) Grevelingen (ontleend aan Sierdsma \& Van den Broek, 2007).

\begin{tabular}{|c|c|c|}
\hline Parameter/ kw aliteits element & Eenheid/beo orde ling s crite rium & GEPwa arde \\
\hline \multicolumn{3}{|l|}{ Fysisch-chemische parameters } \\
\hline Thermische omstand ighe den & ${ }^{\circ} \mathrm{C}$ & $\dot{\mathrm{S}} 25$ \\
\hline \multirow{2}{*}{$\begin{array}{l}\text { Zuurstofhui shoud ing in de } \\
\text { bovenl aag }\end{array}$} & $\mathrm{mg} / 1$ & $6-12$ \\
\hline & $\%$ & $60-120$ \\
\hline Chloride gehalte & $\mathrm{g} \mathrm{Cl}^{-} / 1$ & $14-18$ \\
\hline Zuurgraad & $\mathrm{pH}$ & $5,5-9$ \\
\hline Totaal fosfo $r$ & $\mathrm{mg} \mathrm{P} / 1$ & S0,11 \\
\hline Totaal stikstof & $\mathrm{mg} \mathrm{N} / 1$ & $\dot{\mathrm{S}} 1,8$ \\
\hline Doo rzicht & $\mathrm{m}$ & 0,9 \\
\hline \multicolumn{3}{|l|}{ Biologi sche kwaliteits elemen ten } \\
\hline \multirow[t]{2}{*}{ Fytoplan kton } & $\begin{array}{l}\text { Abundantie } \\
\text { - Chlorofyl-a gehalte }(\mu \mathrm{g} / \mathrm{l})\end{array}$ & $<12$ \\
\hline & $\begin{array}{l}\text { Soorten samenstelling (ne gatieve blo eien ) } \\
\text { - Aan tal cellen Ph a eo cystis }\left(10^{6} \text { cel/1) }\right.\end{array}$ & $<10$ \\
\hline \multirow[t]{2}{*}{ Macrofyten } & $\begin{array}{l}\text { Zeegras } \\
\text { - kwanti teit (\% van po ten tieel be groeibaar } \\
\text { oppervla k be groeid me t zeegras) } \\
\text { - kwaliteit ( } \% \text { begroeide opp ervlak me } t \\
\text { bed ekking zeegras }>60 \% \text { ) }\end{array}$ & $\begin{array}{l}>50 \\
>40\end{array}$ \\
\hline & $\begin{array}{l}\text { Zeesla } \\
-\% \text { geb ied me t overlast }\end{array}$ & $<1 \%$ \\
\hline Macrofauna & - & - \\
\hline \multirow[t]{4}{*}{ Vis } & Aantal diadrome soorten & $3-4$ \\
\hline & Aantal estuarien e res identen & $6-8$ \\
\hline & Aan tal ma riene soo rten & $8-11$ \\
\hline & Aantal zoetwa tersoorten & $0-1$ \\
\hline
\end{tabular}

Sierdsma F., T. van den Broek, 2007. MEP en GEP voor de zoute rijkswateren. Grevelingen. Haskoning referentienummer 9S0926.A0R/902056/Rott1; 


\section{K. Ecotopenkaarten volledige gebied}

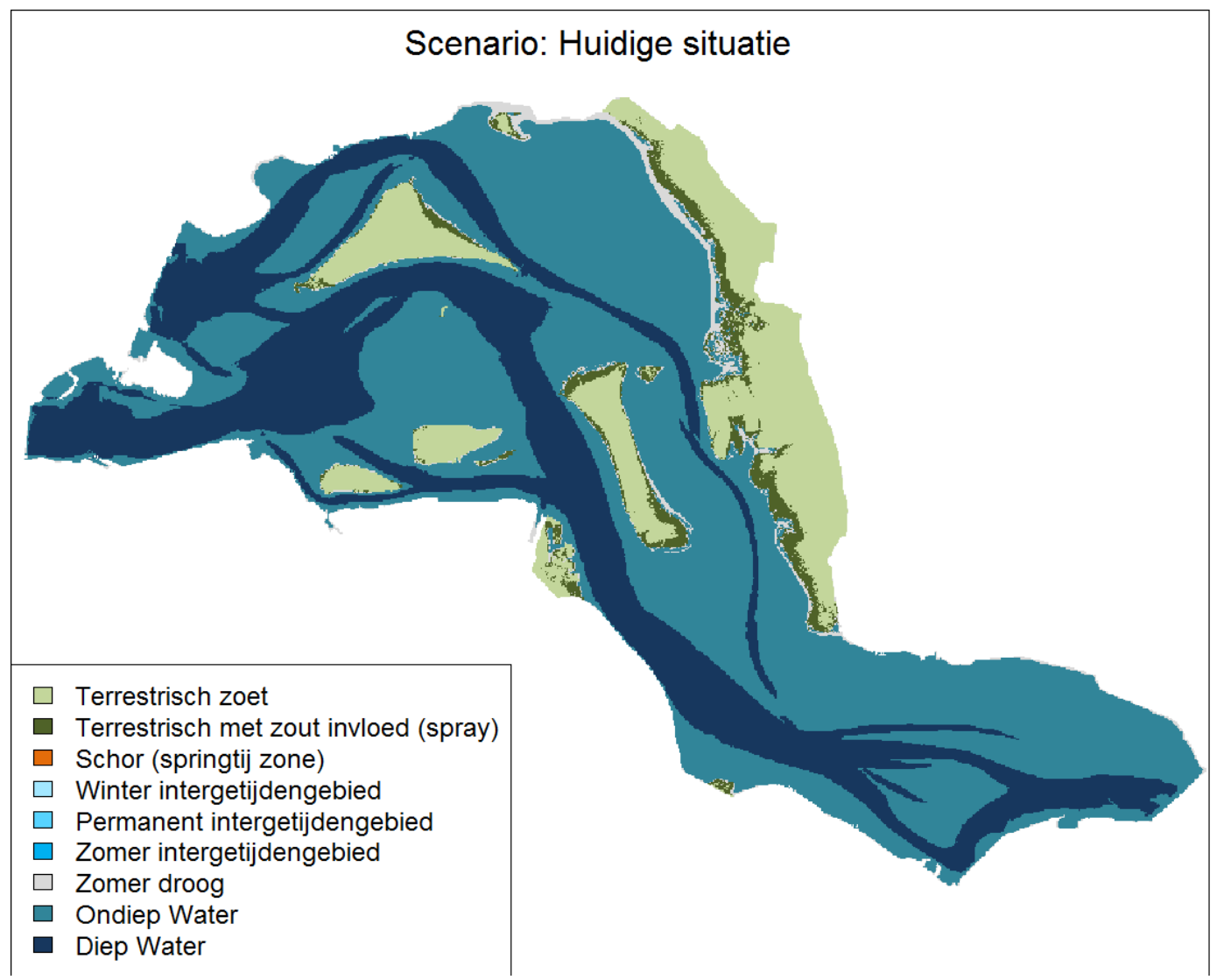

Figuur 27. Ecotopenkaart Grevelingenmeer Huidige situatie.

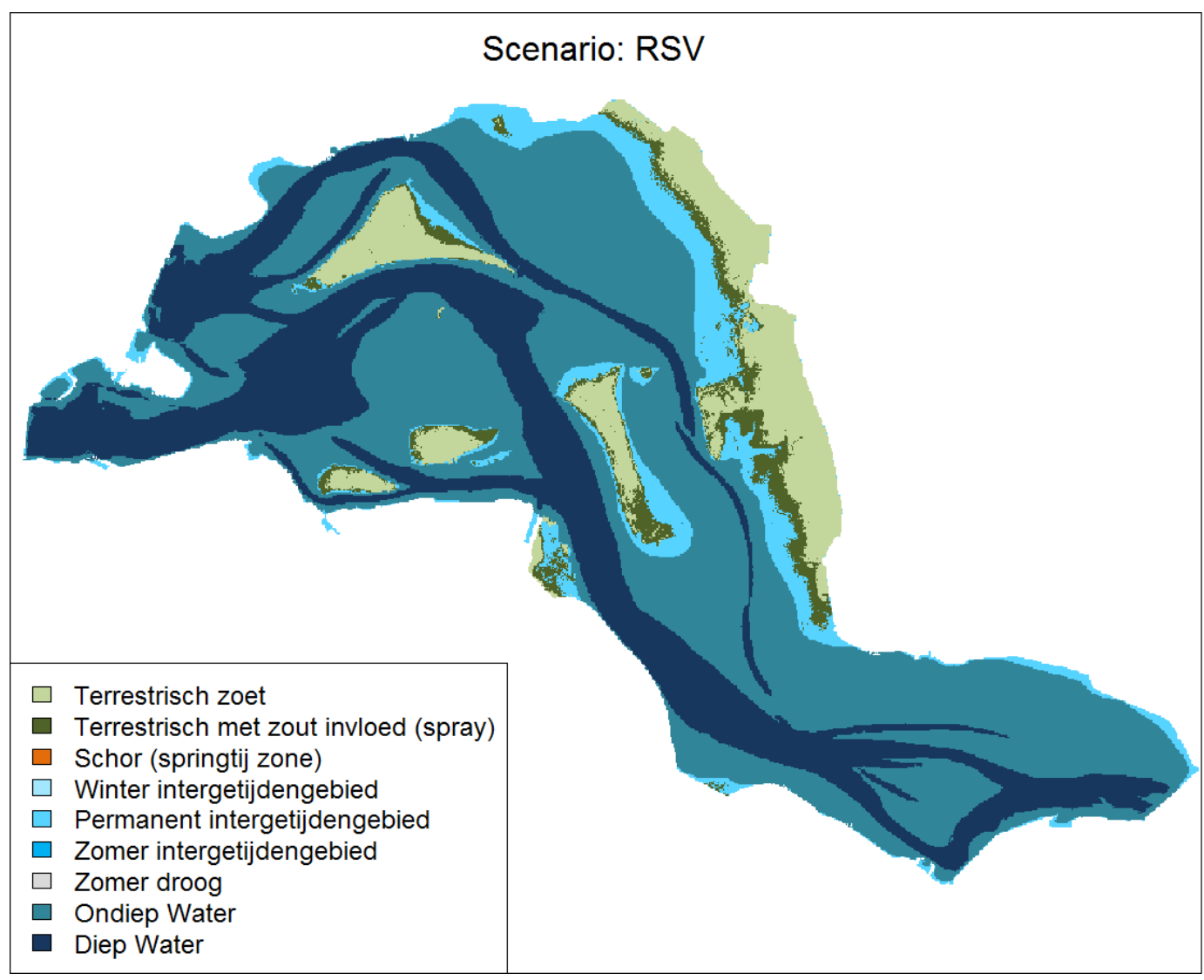

Figuur 28. Ecotopenkaart Grevelingenmeer scenario RSV. 


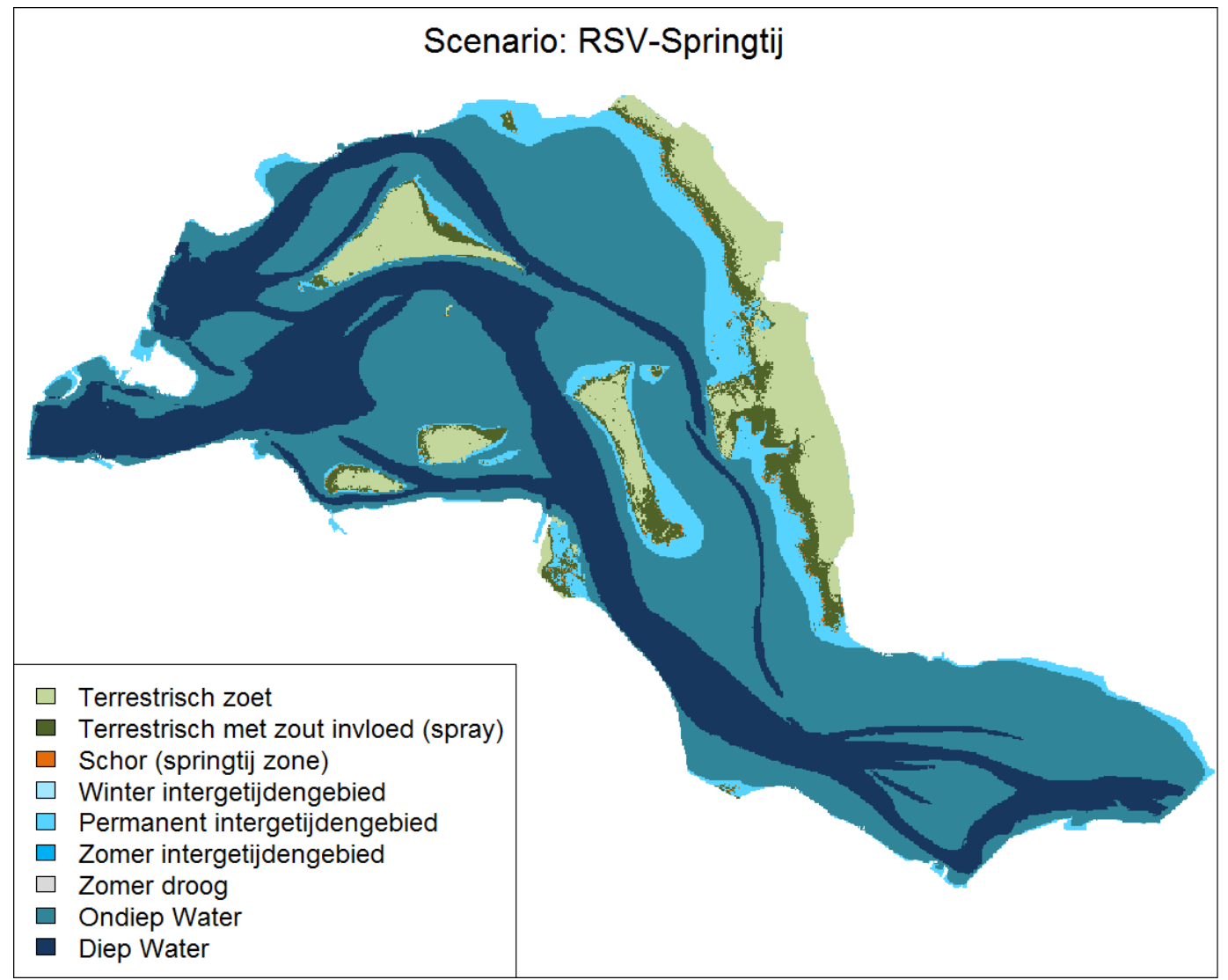

Figuur 29. Ecotopenkaart Grevelingenmeer scenario RSV Springtij.

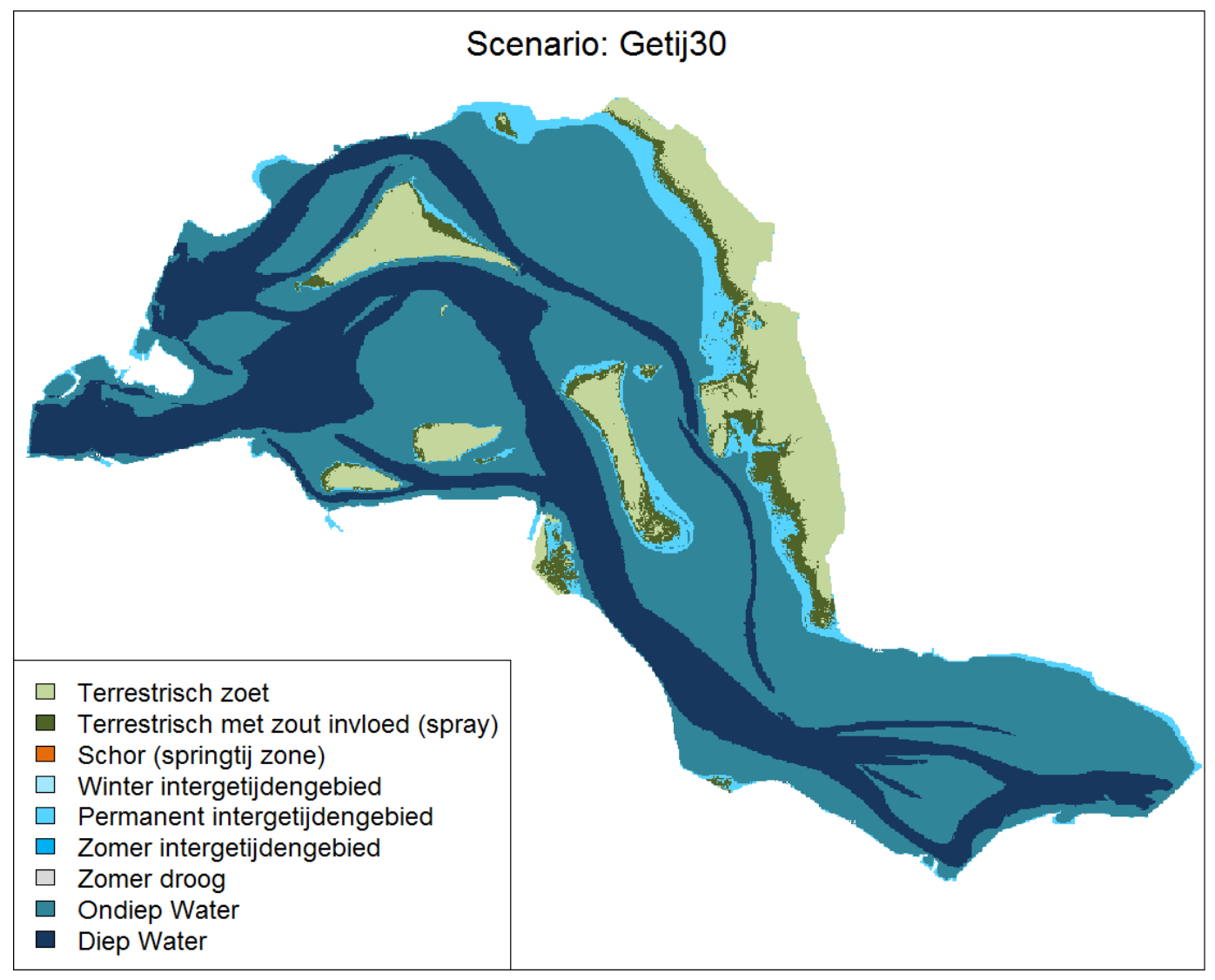

Figuur 30. Ecotopenkaart Grevelingenmeer scenario Getij30. 


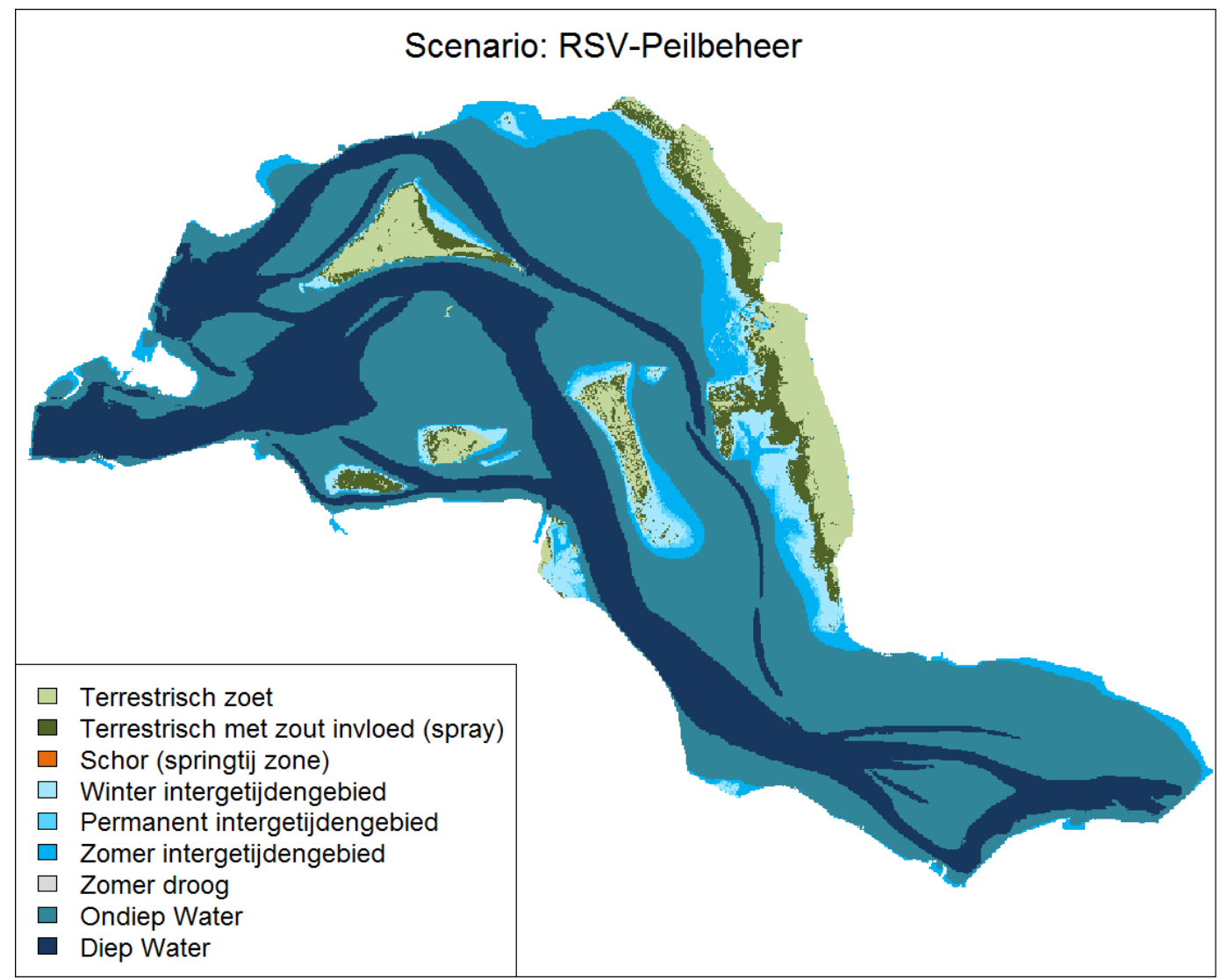

Figuur 31. Ecotopenkaart Grevelingenmeer scenario RSV-Peilbeheer.

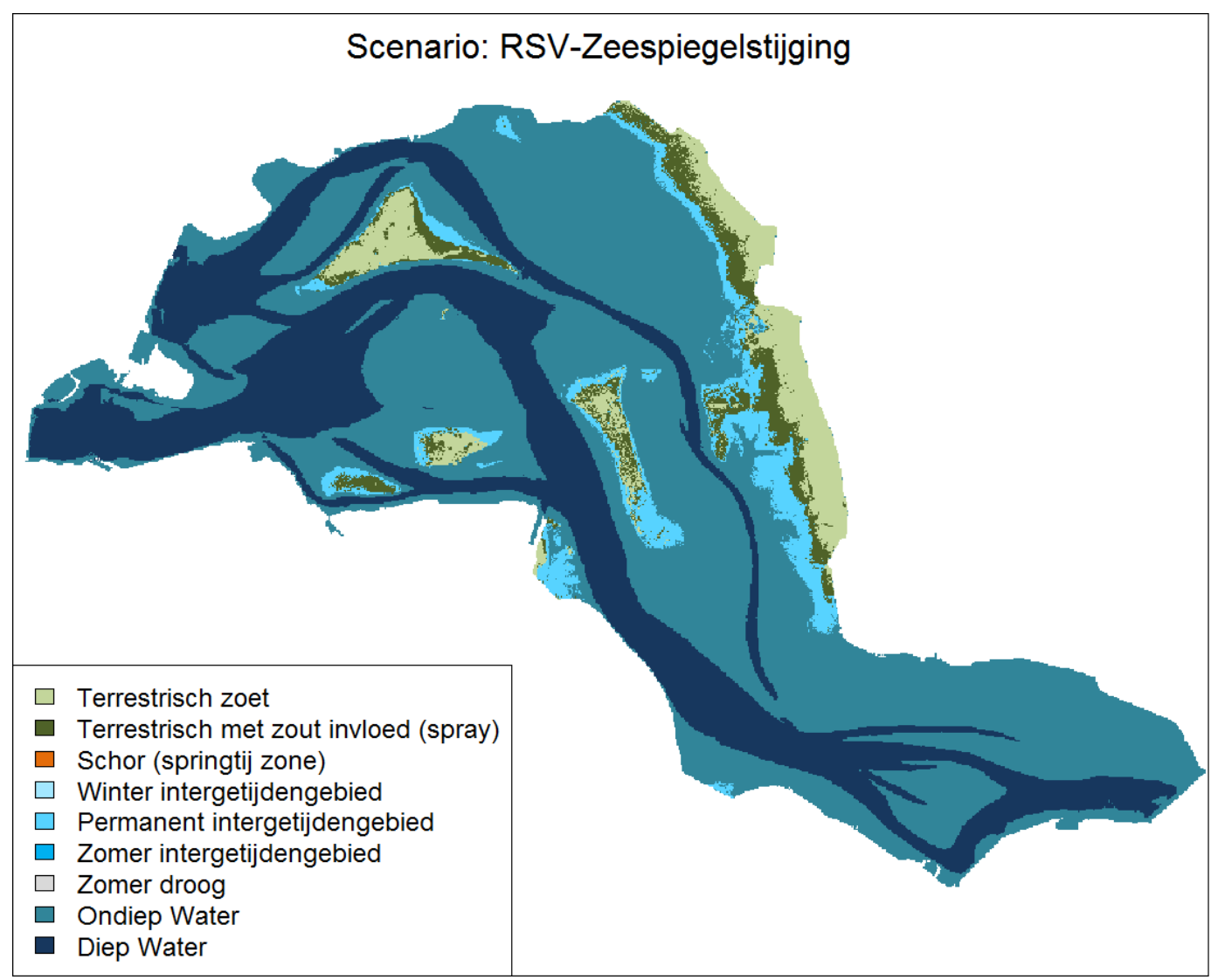

Figuur 32. Ecotopenkaart Grevelingenmeer scenario RSV-Zeespiegelstijging. 


\section{Ecotopenkaarten Hompelvoet}

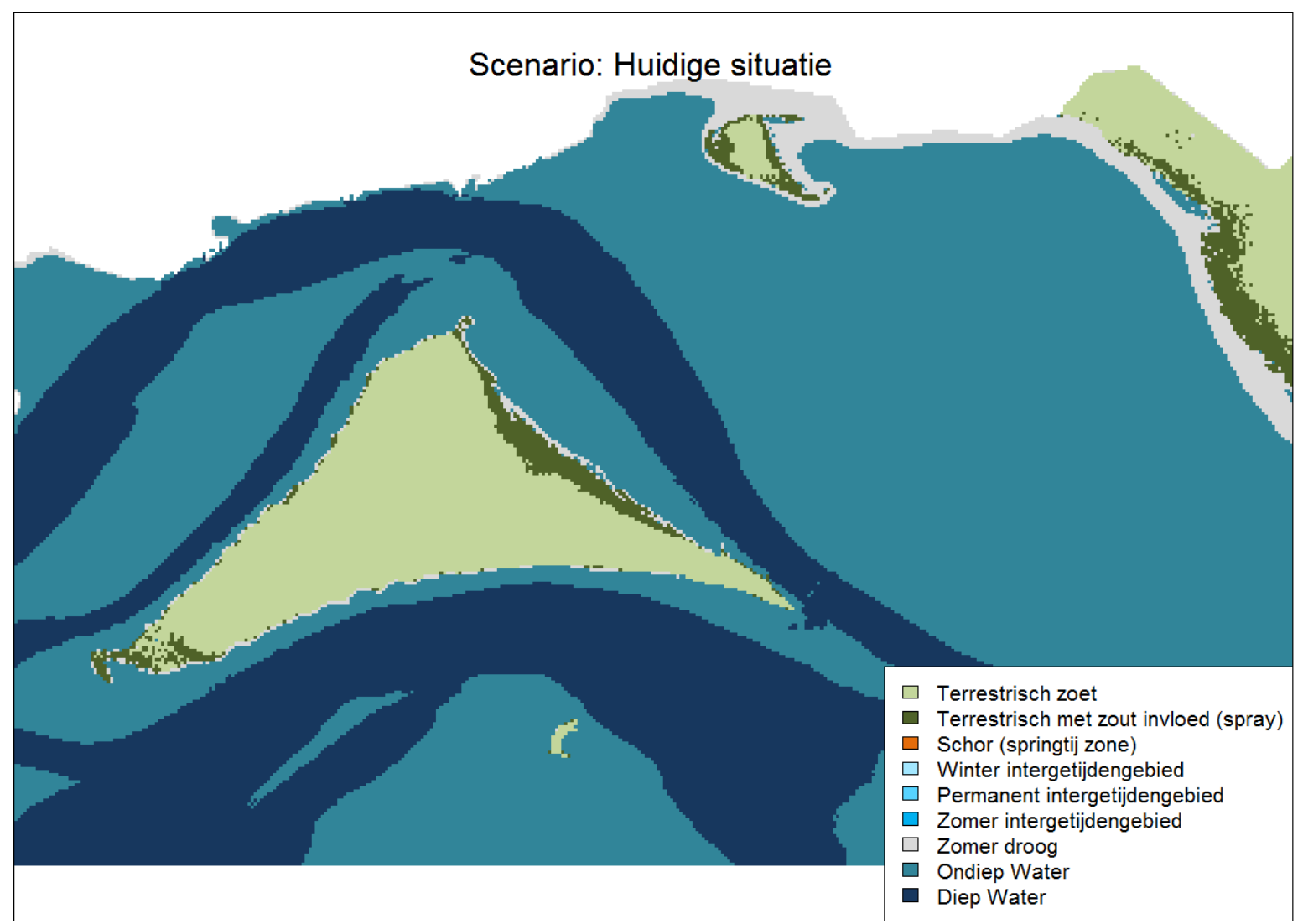

Figuur 33. Ecotopenkaart uitsnede Homple/voet Huidige situatie.

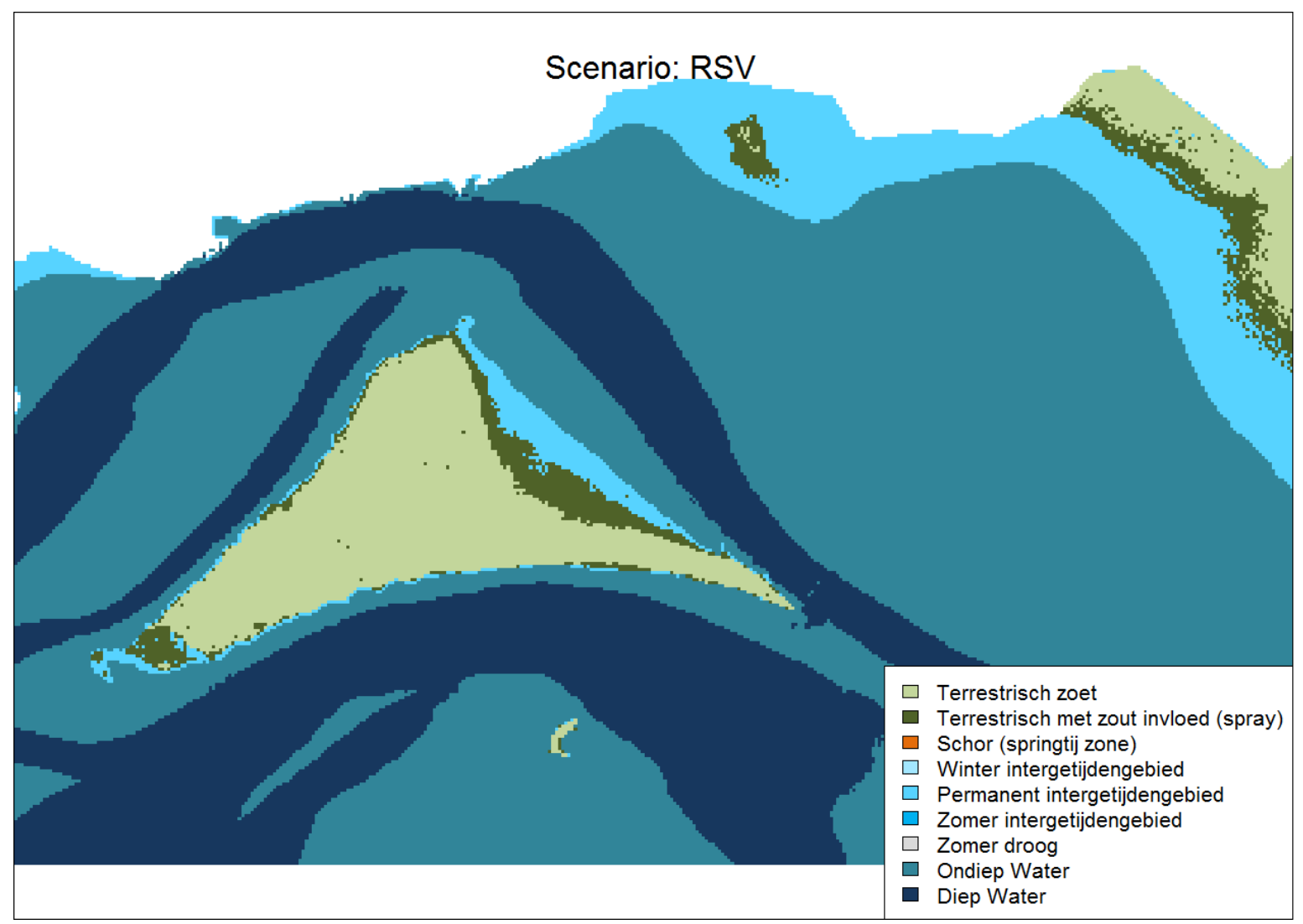

Figuur 34. Ecotopenkaart uitsnede Homplelvoet scenario RSV. 


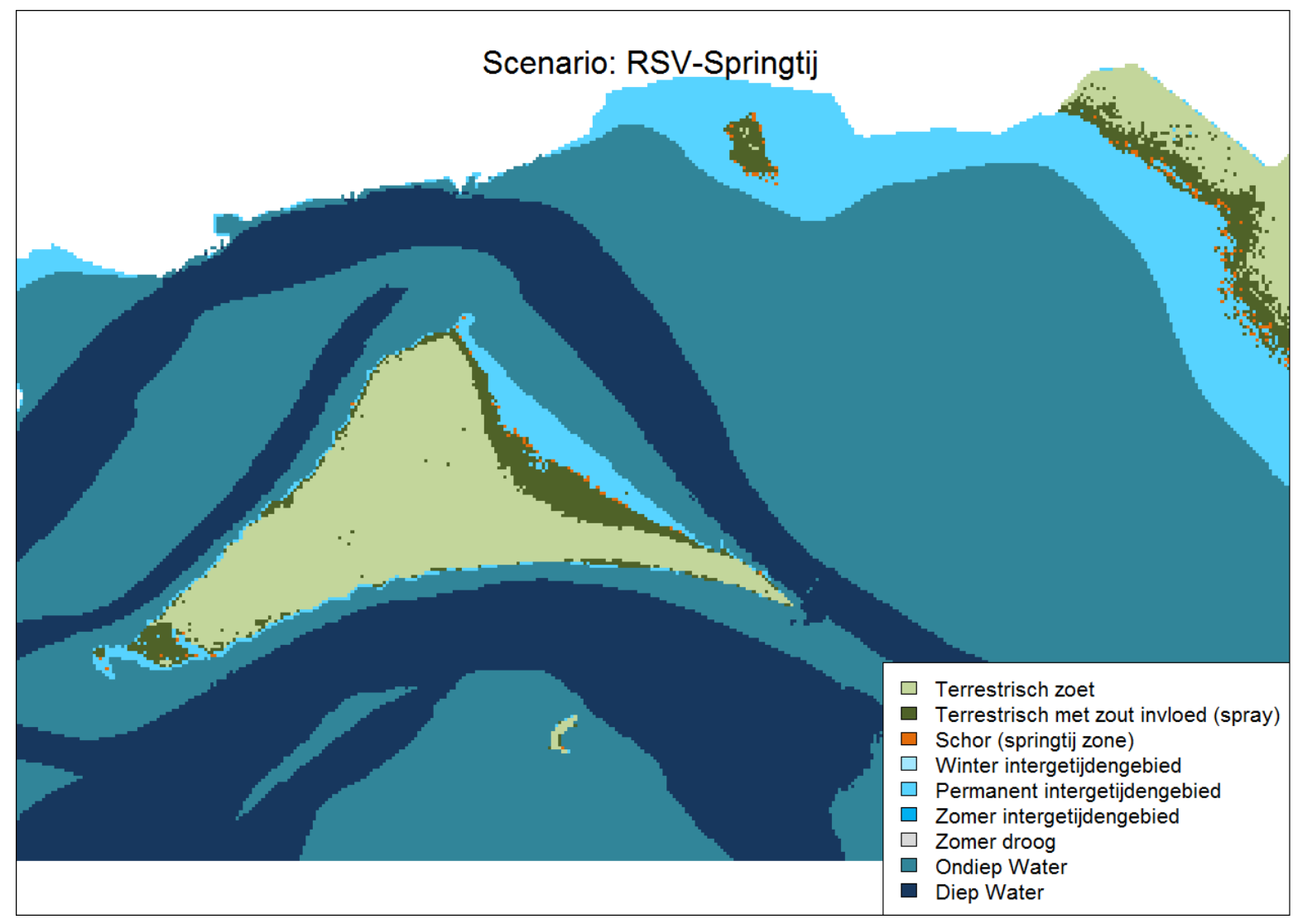

Figuur 35. Ecotopenkaart uitsnede Homplelvoet scenario RSV Springtij.

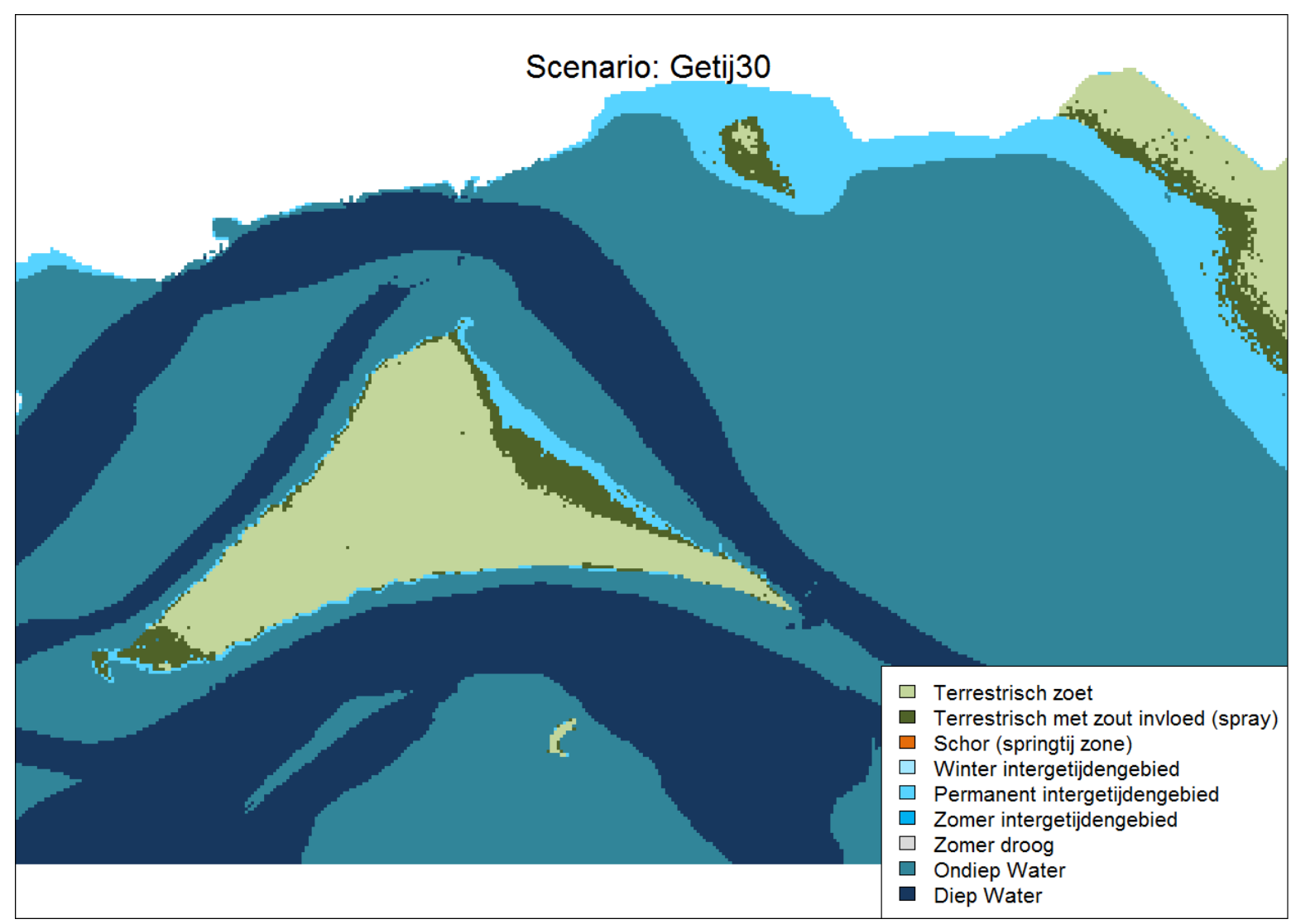

Figuur 36. Ecotopenkaart uitsnede Homplelvoet scenario Getij30. 


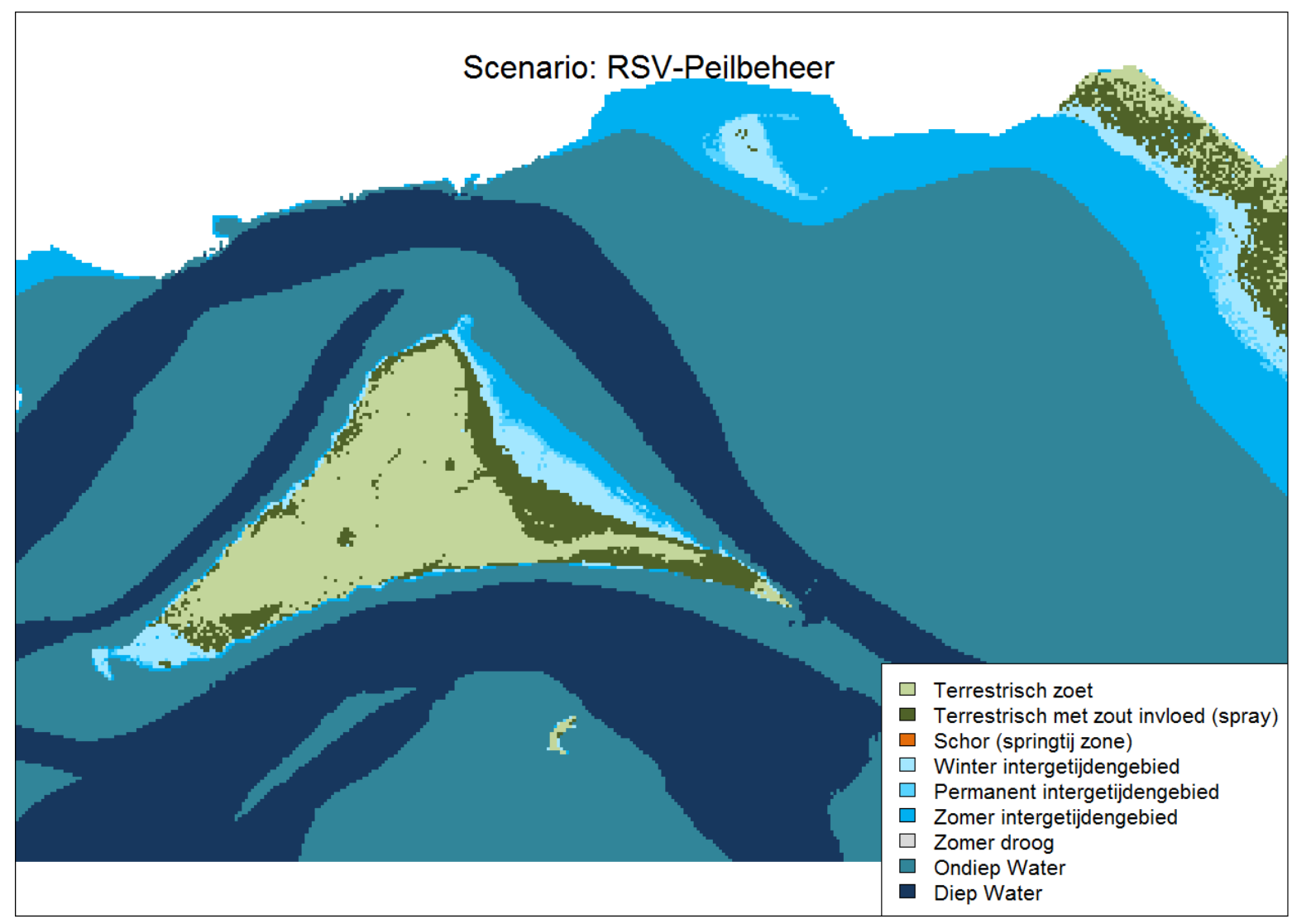

Figuur 37. Ecotopenkaart uitsnede Homplelvoet scenario RSV-Peilbeheer.

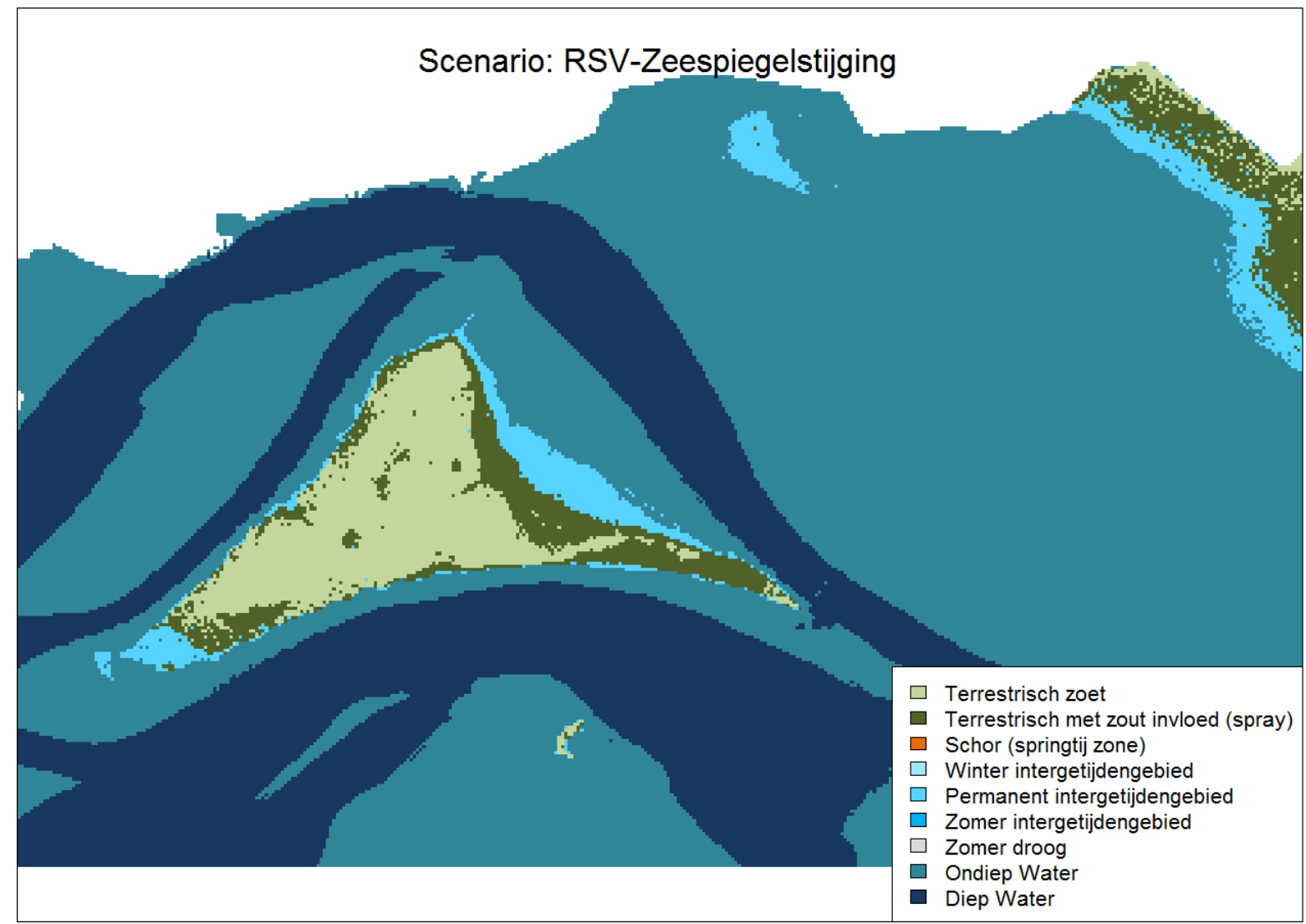

Figuur 38. Ecotopenkaart uitsnede Homplelvoet scenario RSV-Zeespiegelstijging. 


\section{Ecotopenkaarten Veermansplaat}

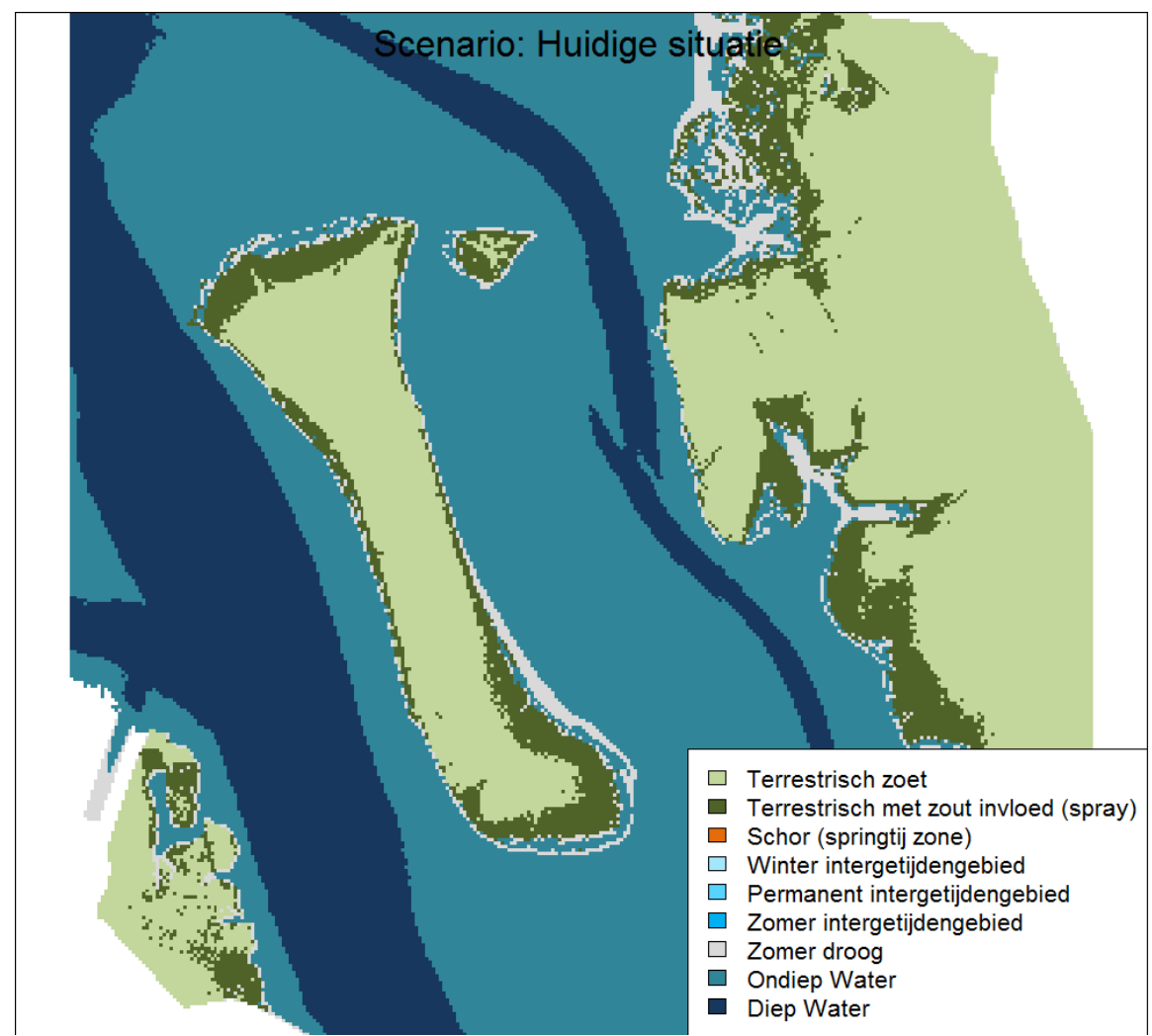

Figuur 39. Ecotopenkaart uitsnede Veermansplaten scenario 0 'Huidige situatie'.

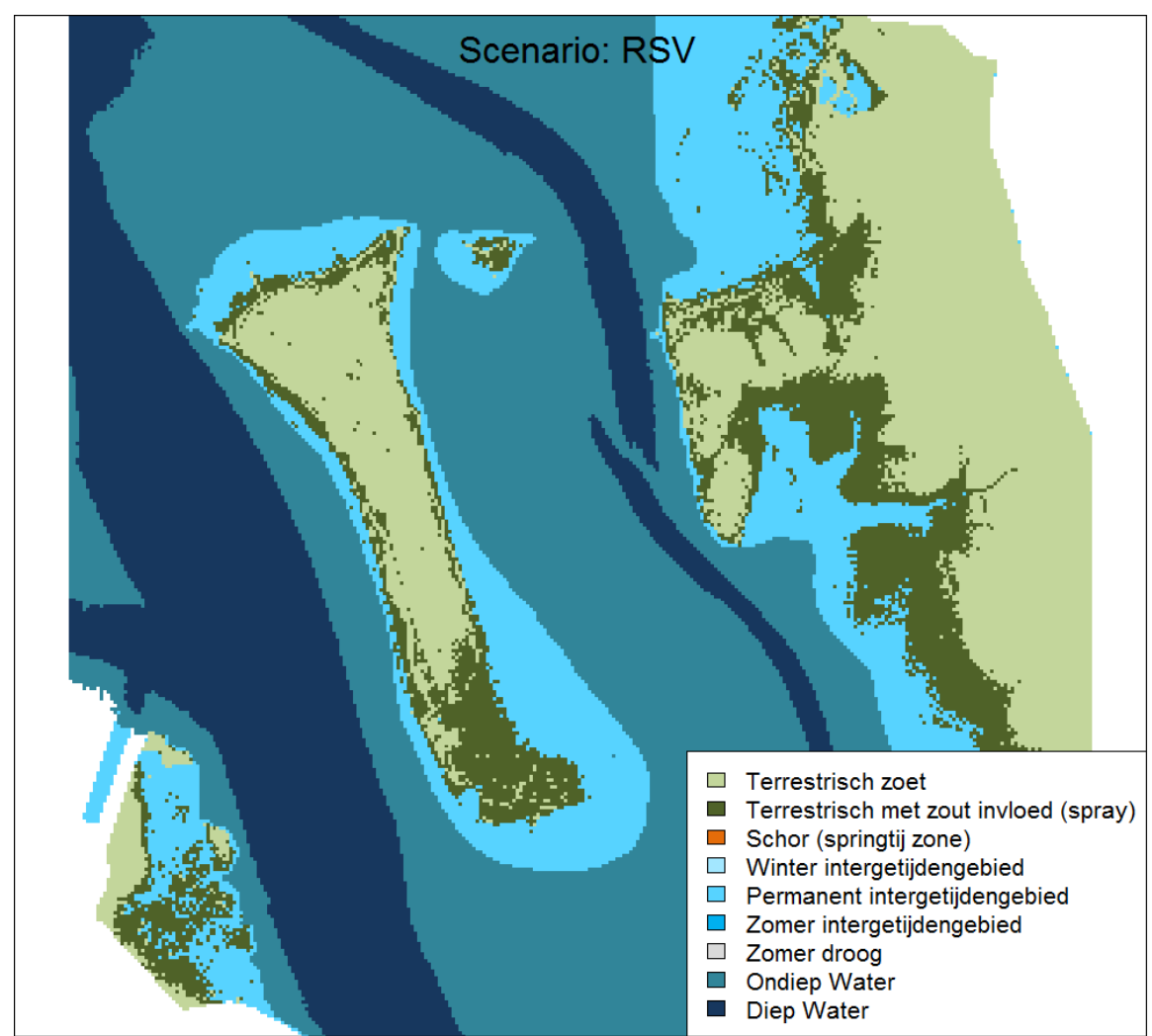

Figuur 40. Ecotopenkaart uitsnede Veermansplaten scenario RSV. 


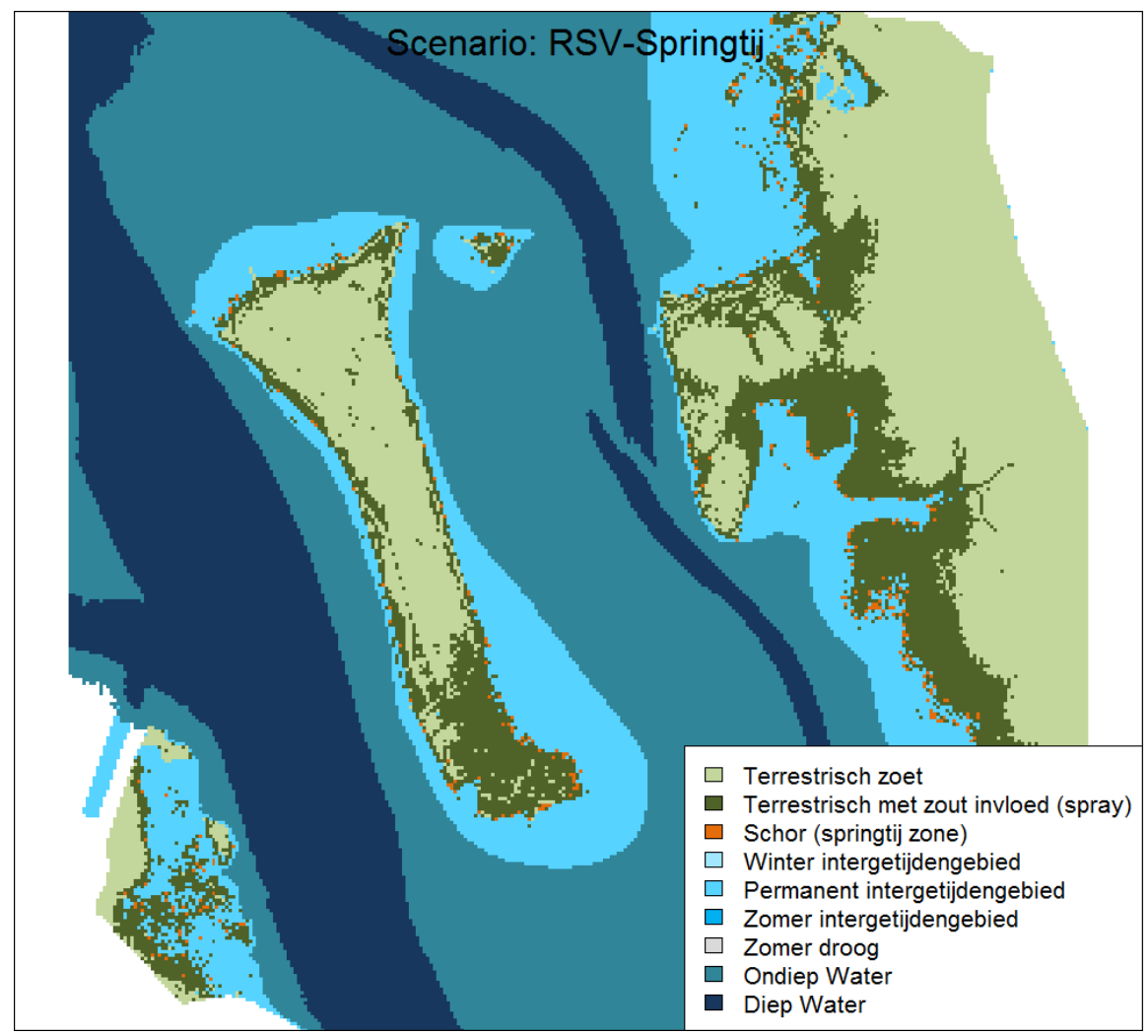

Figuur 41. Ecotopenkaart uitsnede Veermansplaten scenario RSV Springtij.

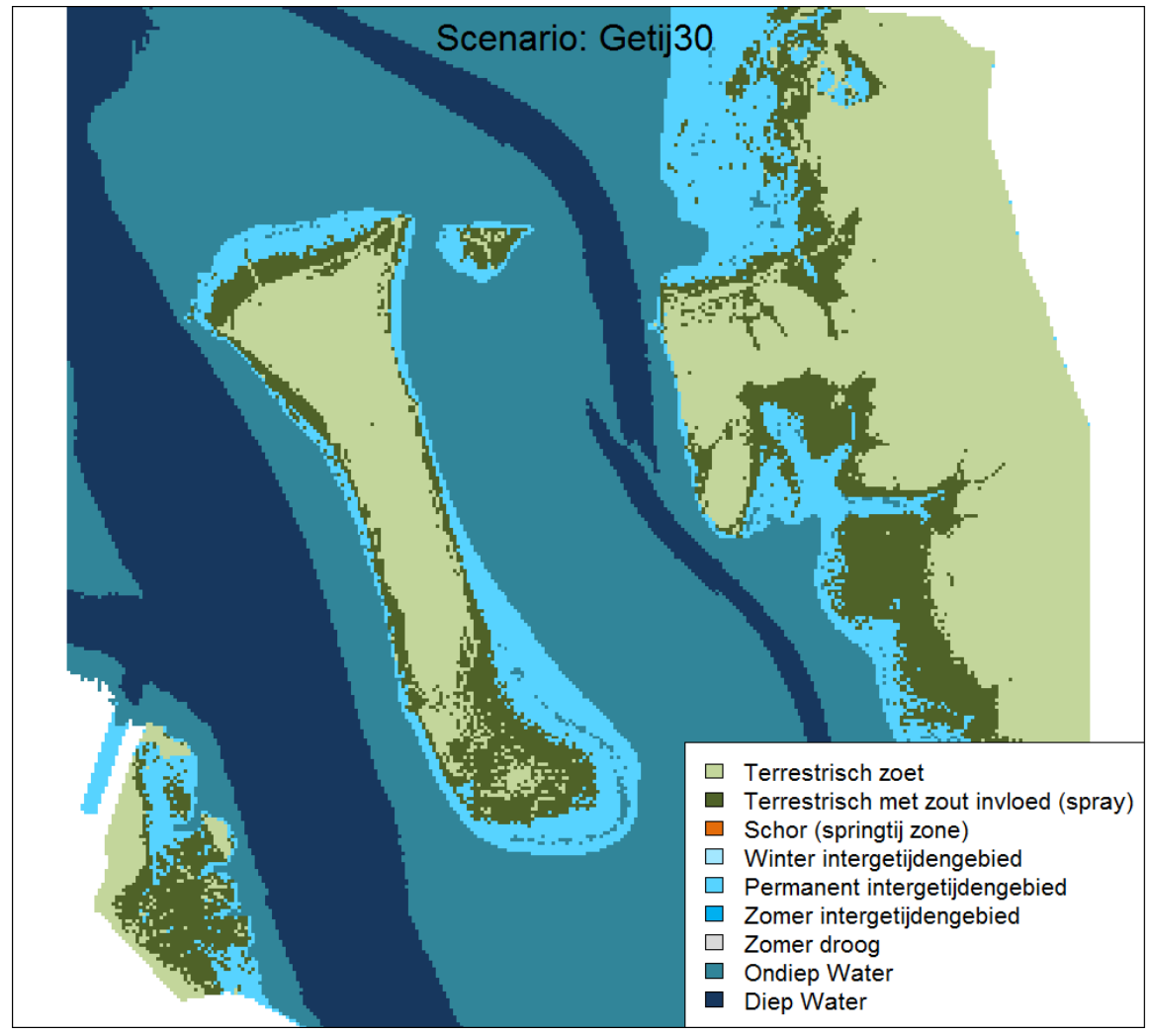

Figuur 42. Ecotopenkaart uitsnede Veermansplaten scenario Getij30. 


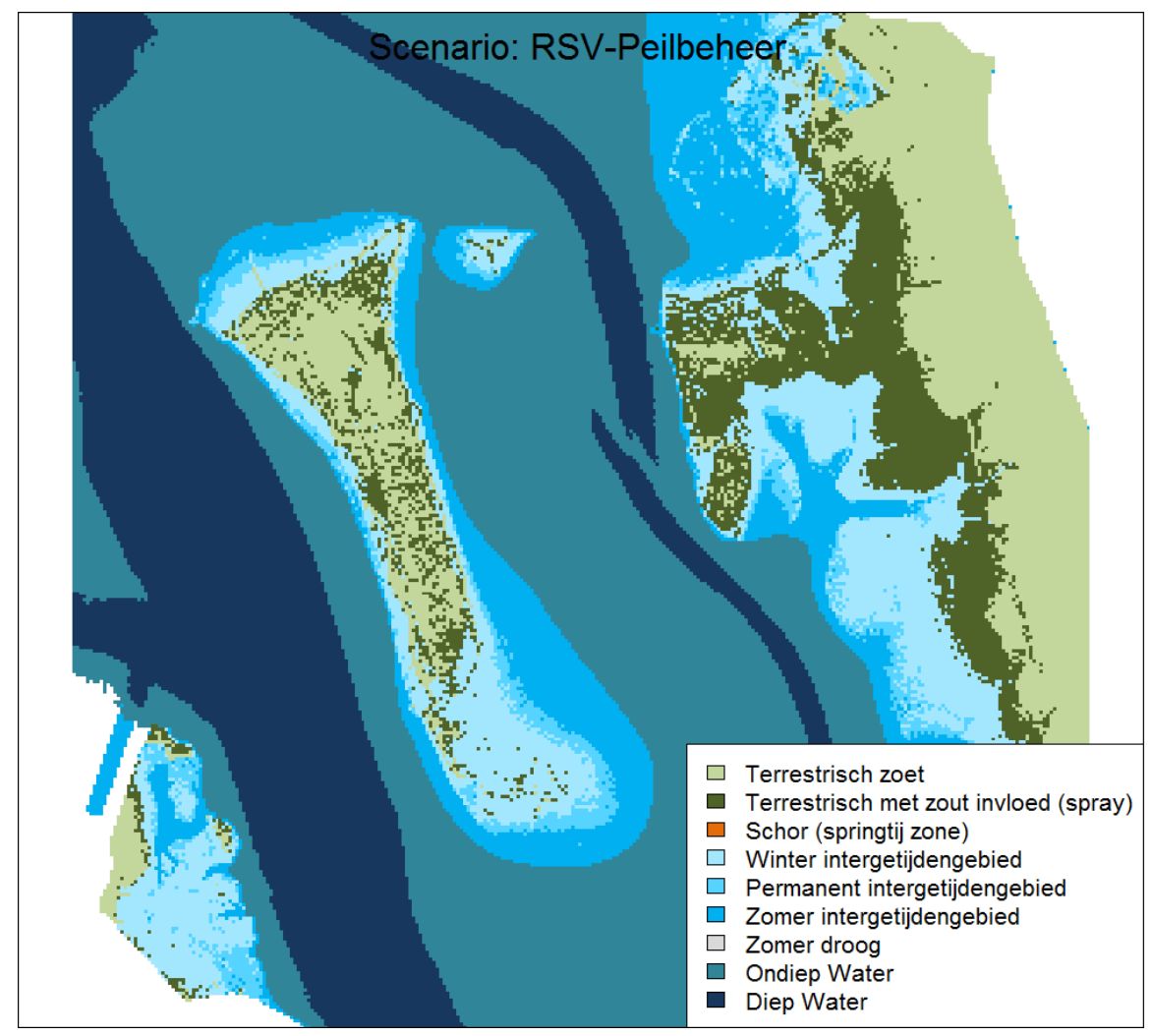

Figuur 43. Ecotopenkaart uitsnede Veermansplaten scenario RSV-Peilbeheer.

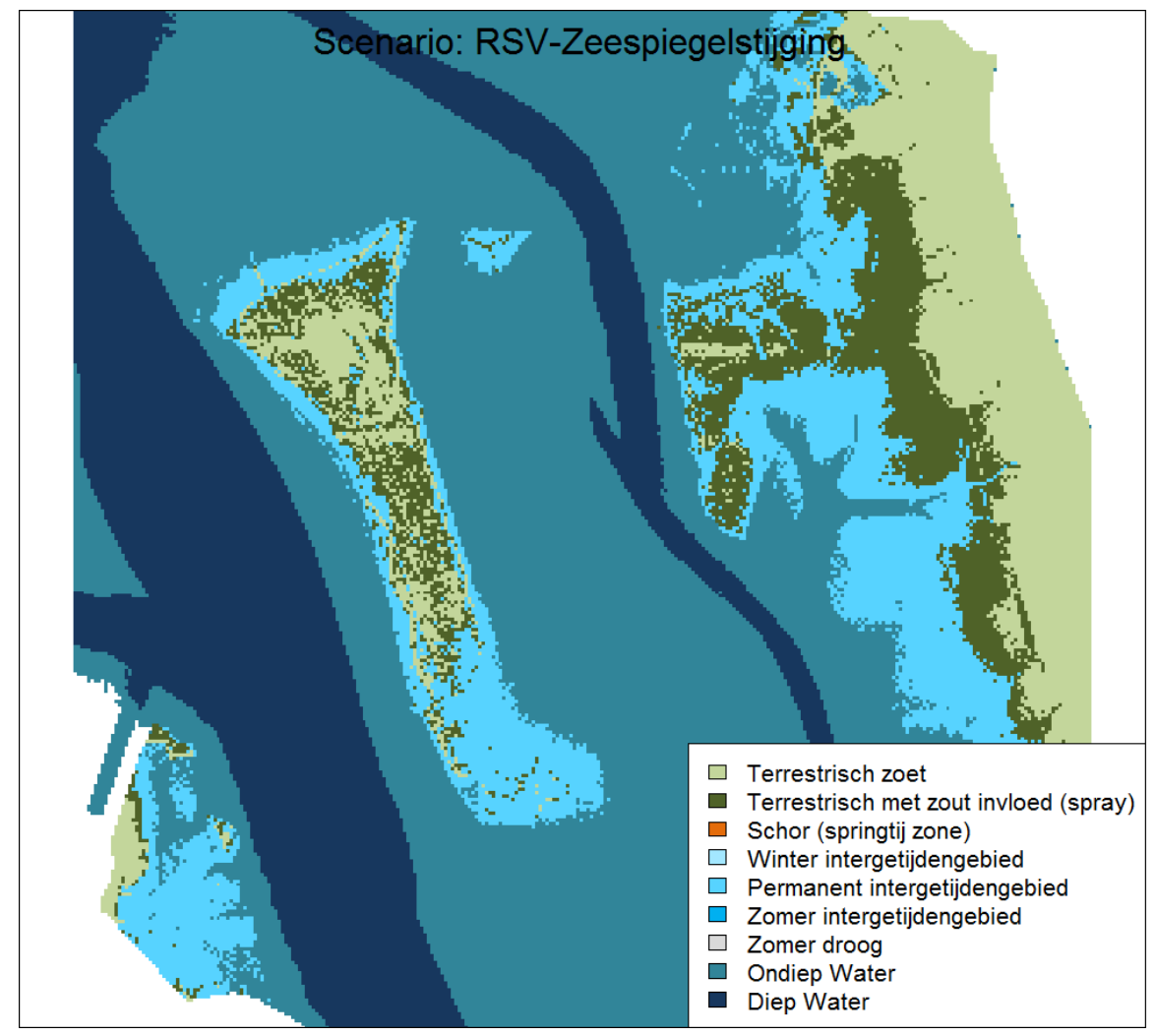

Figuur 44. Ecotopenkaart uitsnede Veermansplaten scenario RSV-Zeespiegelstijging. 


\section{N. Effect op habitattypen H1310A en H2190B}

In deze bijlage wordt de overspoeling van de habitattypen H1310A Zilte pionierbegroeiingen met zeekraal en H2190B vochtige duinvallei vegetaties - kalkrijk weergegeven. Per scenario worden steeds twee kaarten weergegeven: één gebaseerd op de habitatkaart van Bureau Waardenburg (2013) en de ander gebaseerd op de habitatkaart van Alterra Wageningen UR (2011).
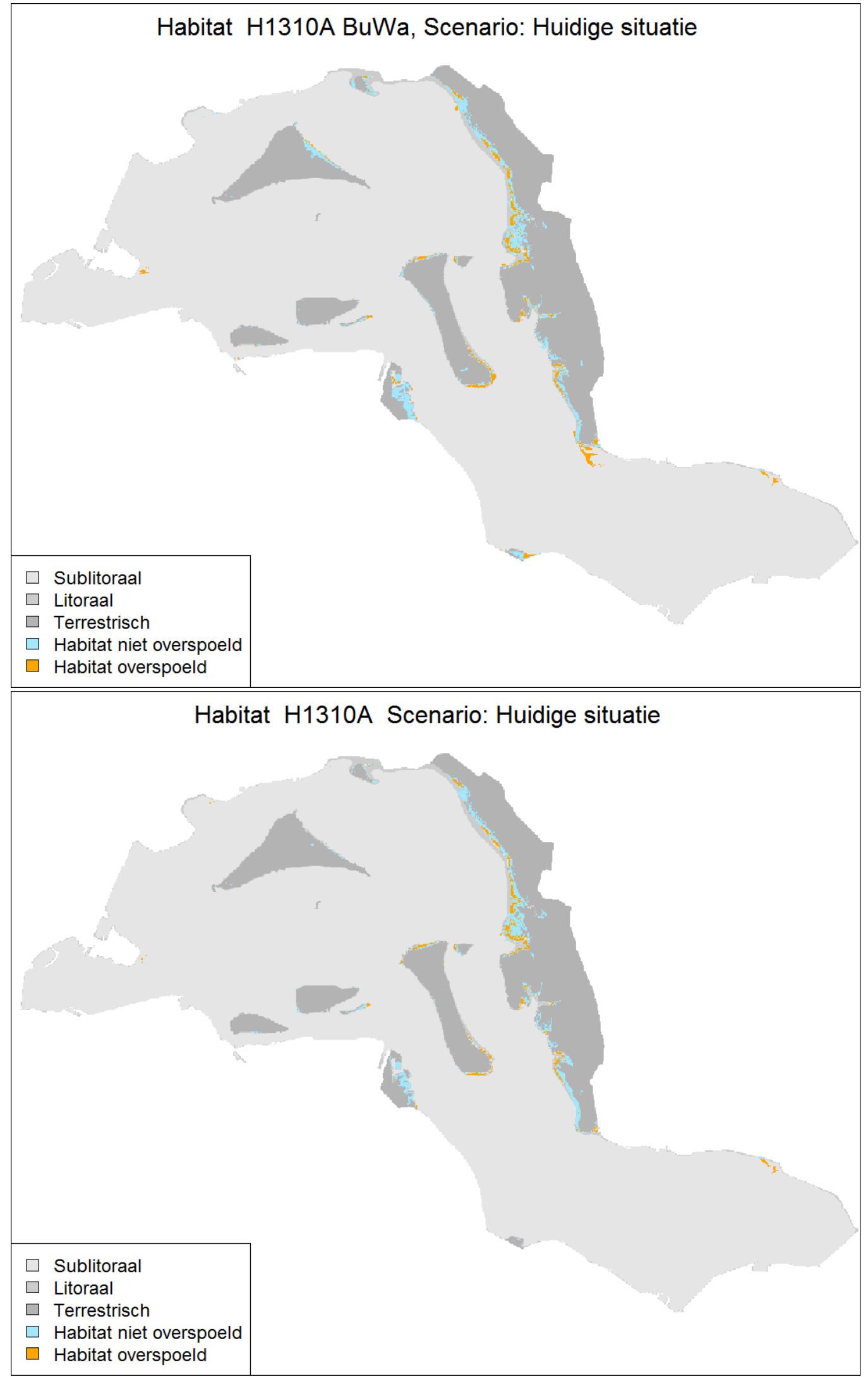


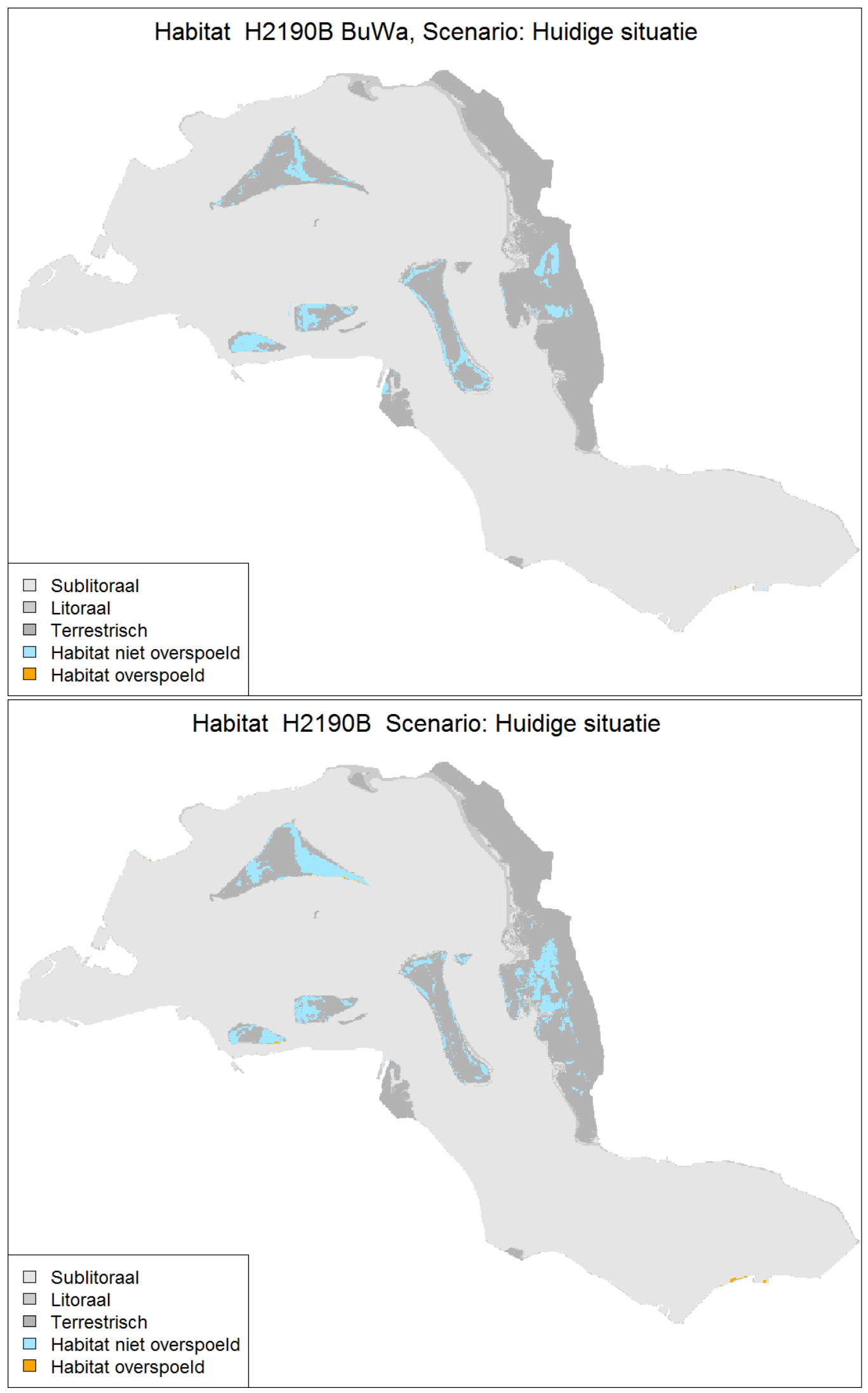

Figuur 45. Huidige ligging van habitattypen H1310A: Zilte pionierbegroeiingen (zeekraal) en H2190B: Vochtige duinvalleien (kalkrijk) in relatie tot het berekende areaal sublitoraal, litoraal en terrestrisch in de Huidige situatie. Blauwe tinten blijven behouden, oranje tinten overspoelen. De bovenste kaarten zijn gebaseerd op de habitatkaart van Bureau Waardenburg (2013) "BuWa" en de onderste kaarten zijn gebaseerd op de habitatkaart van Alterra Wageningen UR (2011). 


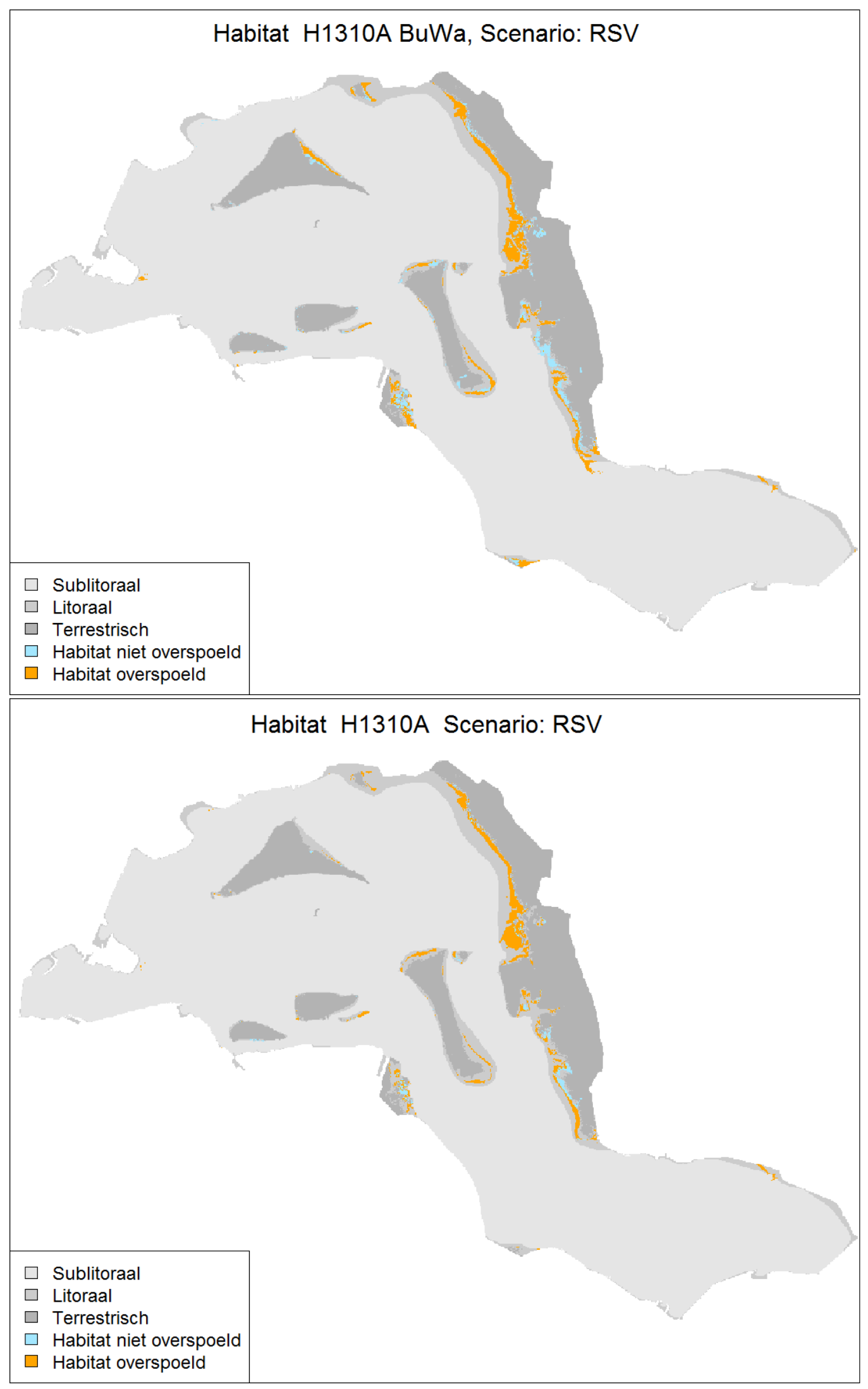



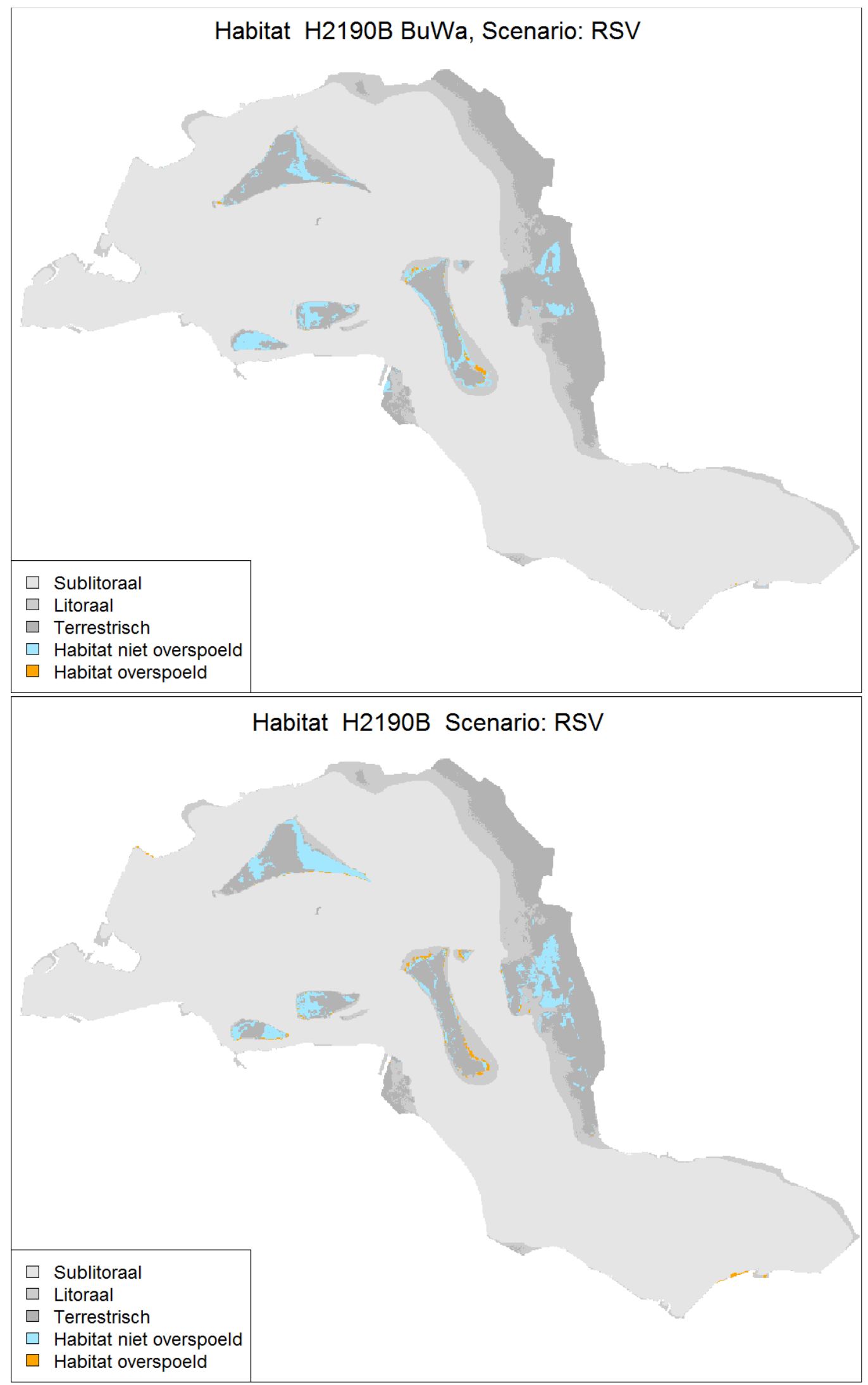

Figuur 46. Huidige ligging van habitattypen H1310A: Zilte pionierbegroeiingen (zeekraal) en H2190B: Vochtige duinvalleien (kalkrijk) in relatie tot het berekende areaal sublitoraal, litoraal en terrestrisch in RSV scenario. Blauwe tinten blijven behouden, oranje tinten overspoelen. De bovenste kaarten zijn gebaseerd op de habitatkaart van Bureau Waardenburg (2013) "BuWa" en de onderste kaarten zijn gebaseerd op de habitatkaart van Alterra Wageningen UR (2011). 


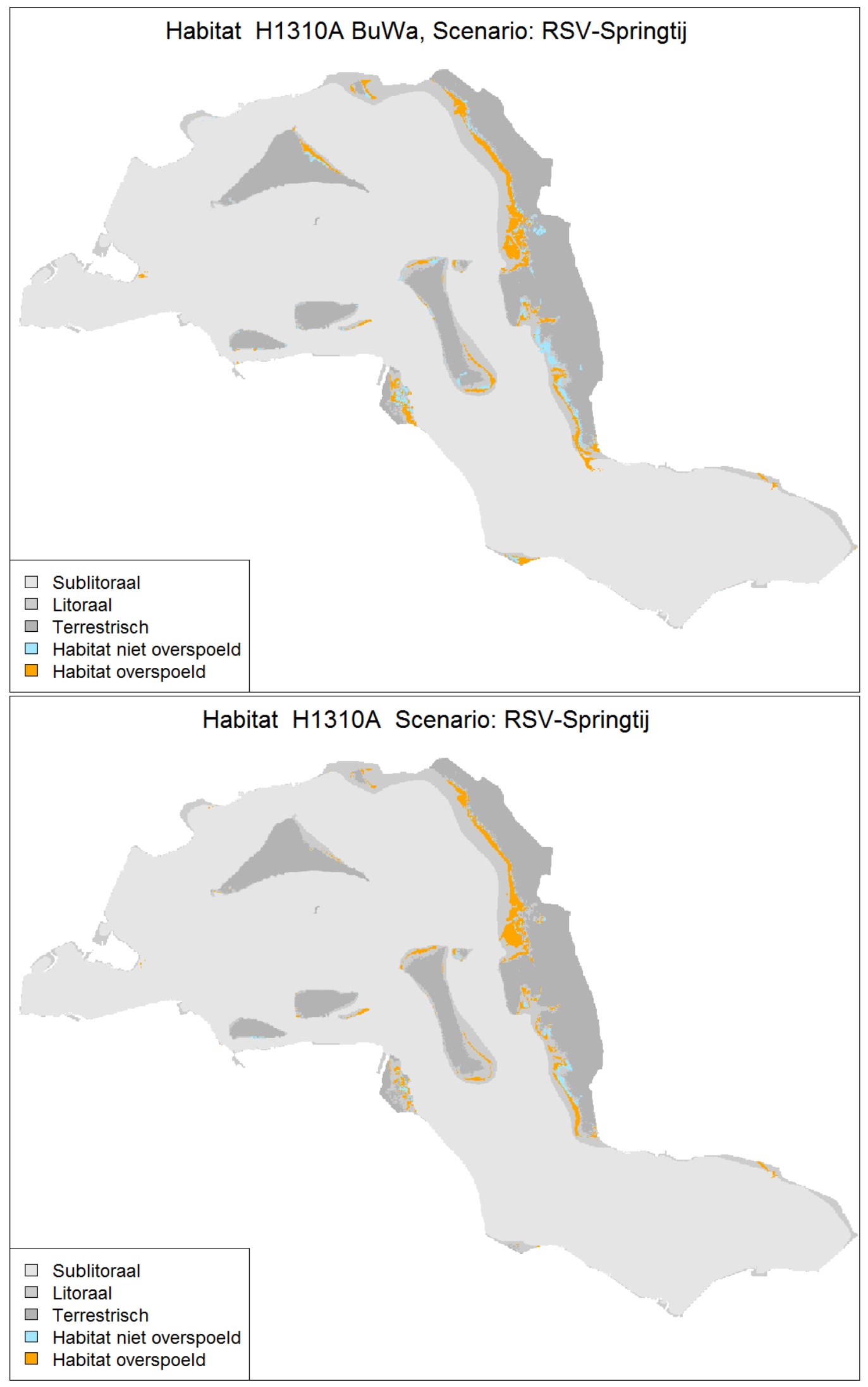



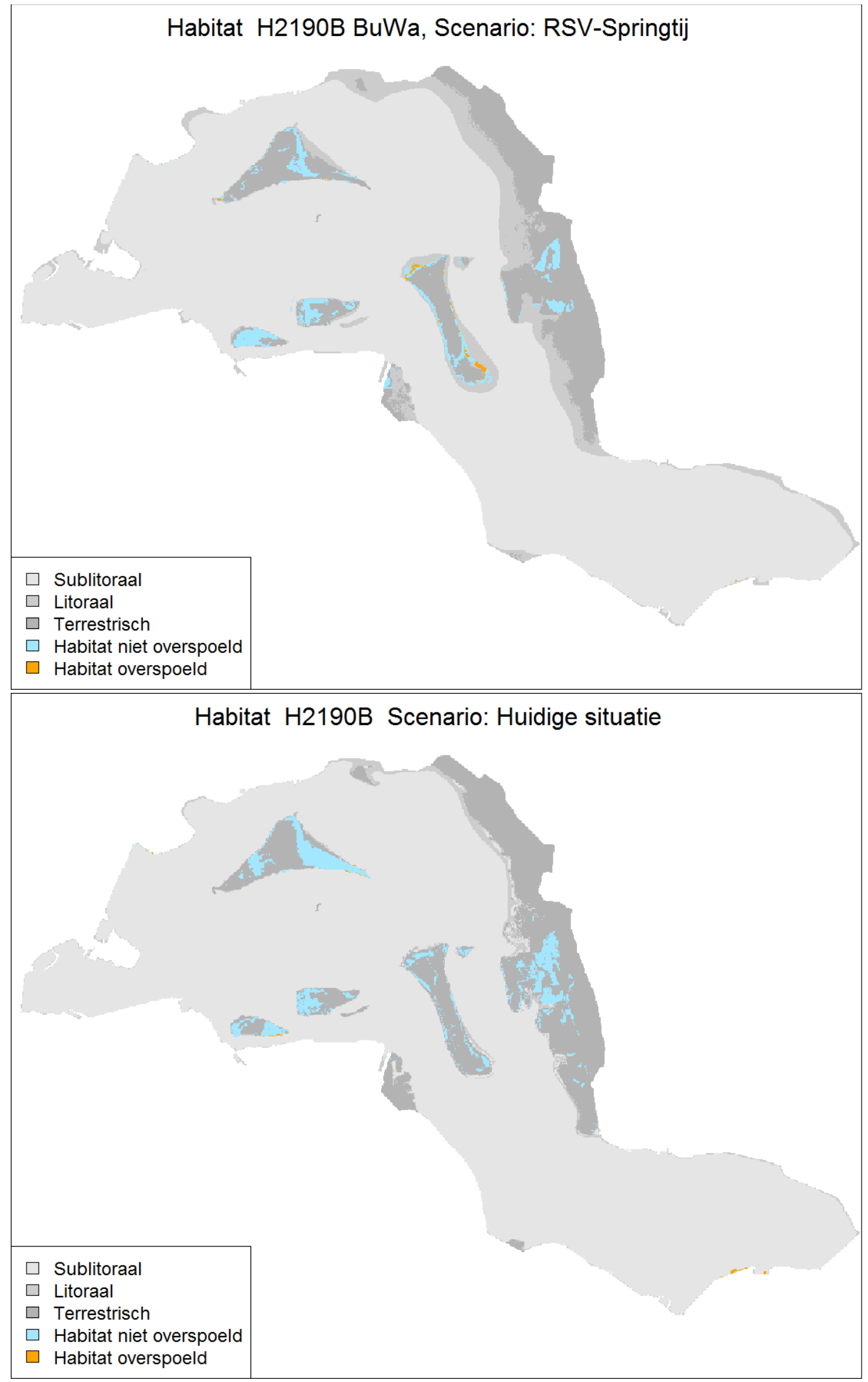

Figuur 47. Huidige ligging van habitattypen H1310A: Zilte pionierbegroeiingen (zeekraal) en H2190B: Vochtige duinvalleien (kalkrijk) in relatie tot het berekende areaal sublitoraal, litoraal en terrestrisch in RSV Springtij scenario. Blauwe tinten blijven behouden, oranje tinten overspoelen. De bovenste kaarten zijn gebaseerd op de habitatkaart van Bureau Waardenburg (2013) "BuWa" en de onderste kaarten zijn gebaseerd op de habitatkaart van Alterra Wageningen UR (2011). 


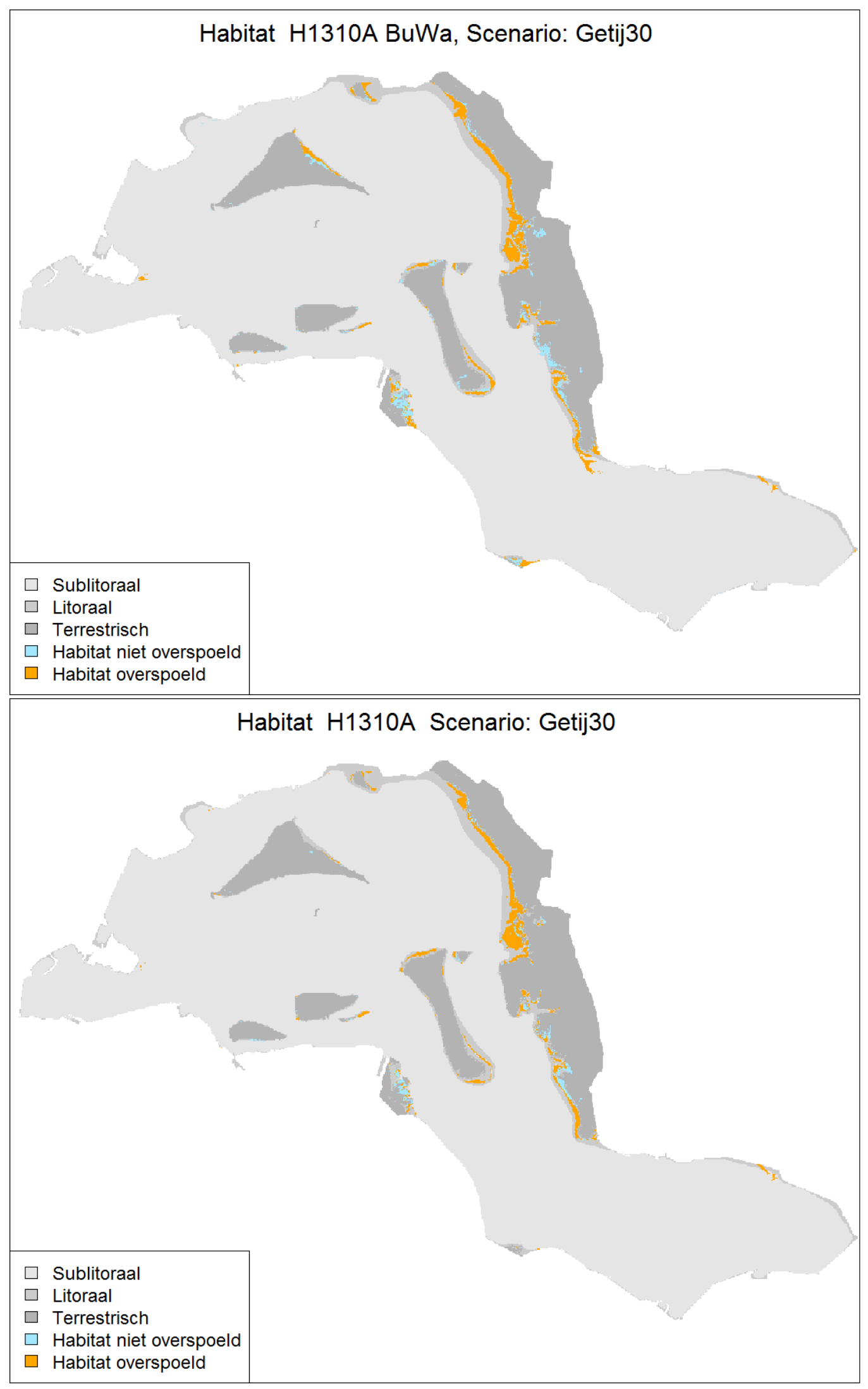



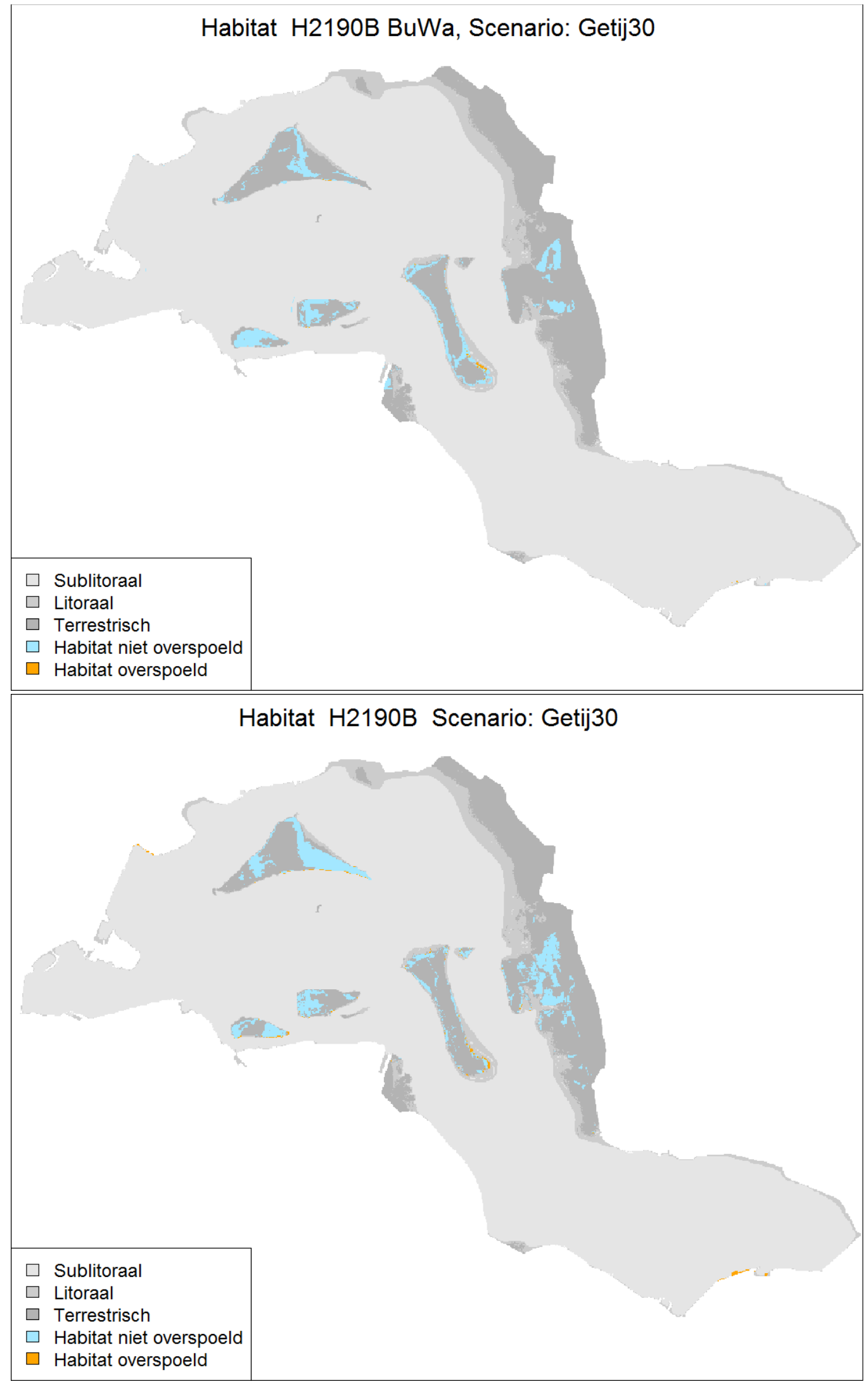

Figuur 48. Huidige ligging van habitattypen H1310A: Zilte pionierbegroeiingen (zeekraal) en H2190B: Vochtige duinvalleien (kalkrijk) in relatie tot het berekende areaal sublitoraal, litoraal en terrestrisch in Getij30 scenario. Blauwe tinten blijven behouden, oranje tinten overspoelen. De bovenste kaarten zijn gebaseerd op de habitatkaart van Bureau Waardenburg (2013) "BuWa" en de onderste kaarten zijn gebaseerd op de habitatkaart van Alterra Wageningen UR (2011). 


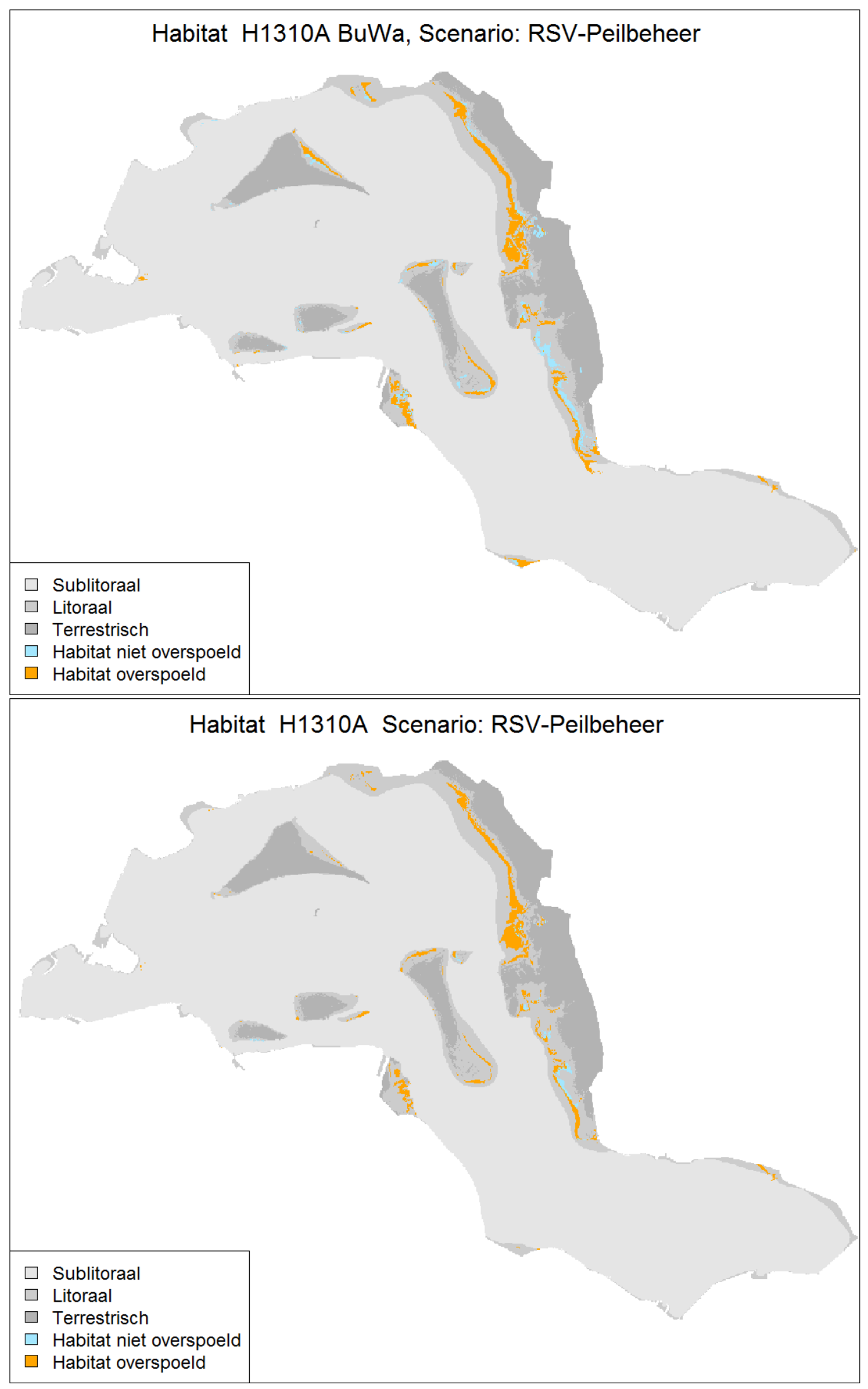




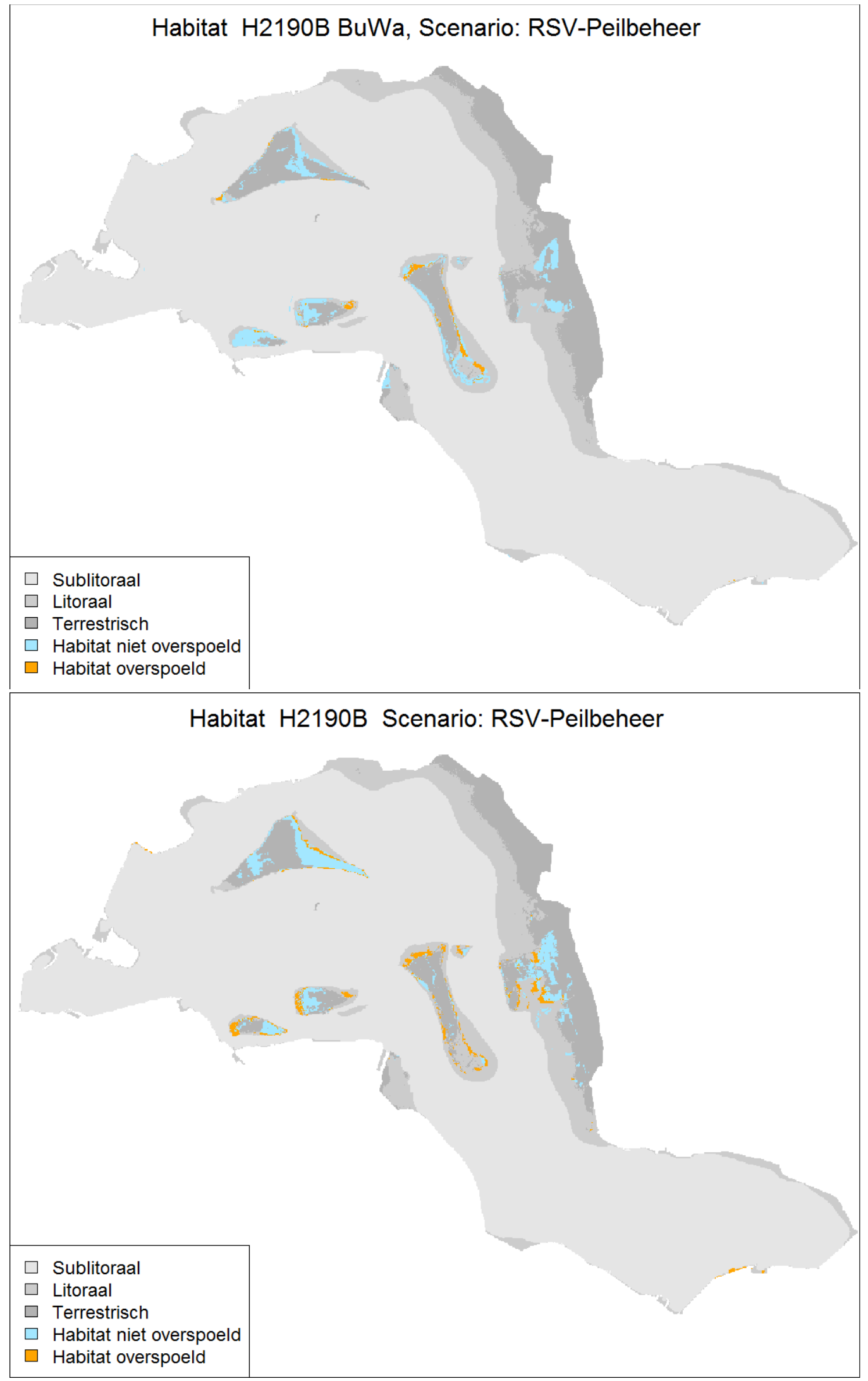

Figuur 49. . Huidige ligging van habitattypen H1310A: Zilte pionierbegroeiingen (zeekraal) en H2190B: Vochtige duinvalleien (kalkrijk) in relatie tot het berekende areaal sublitoraal, litoraal en terrestrisch in RSV Peilbeheer scenario. Blauwe tinten blijven behouden, oranje tinten overspoelen. De bovenste kaarten zijn gebaseerd op de habitatkaart van Bureau Waardenburg (2013) "BuWa" en de onderste kaarten zijn gebaseerd op de habitatkaart van Alterra Wageningen UR (2011). 


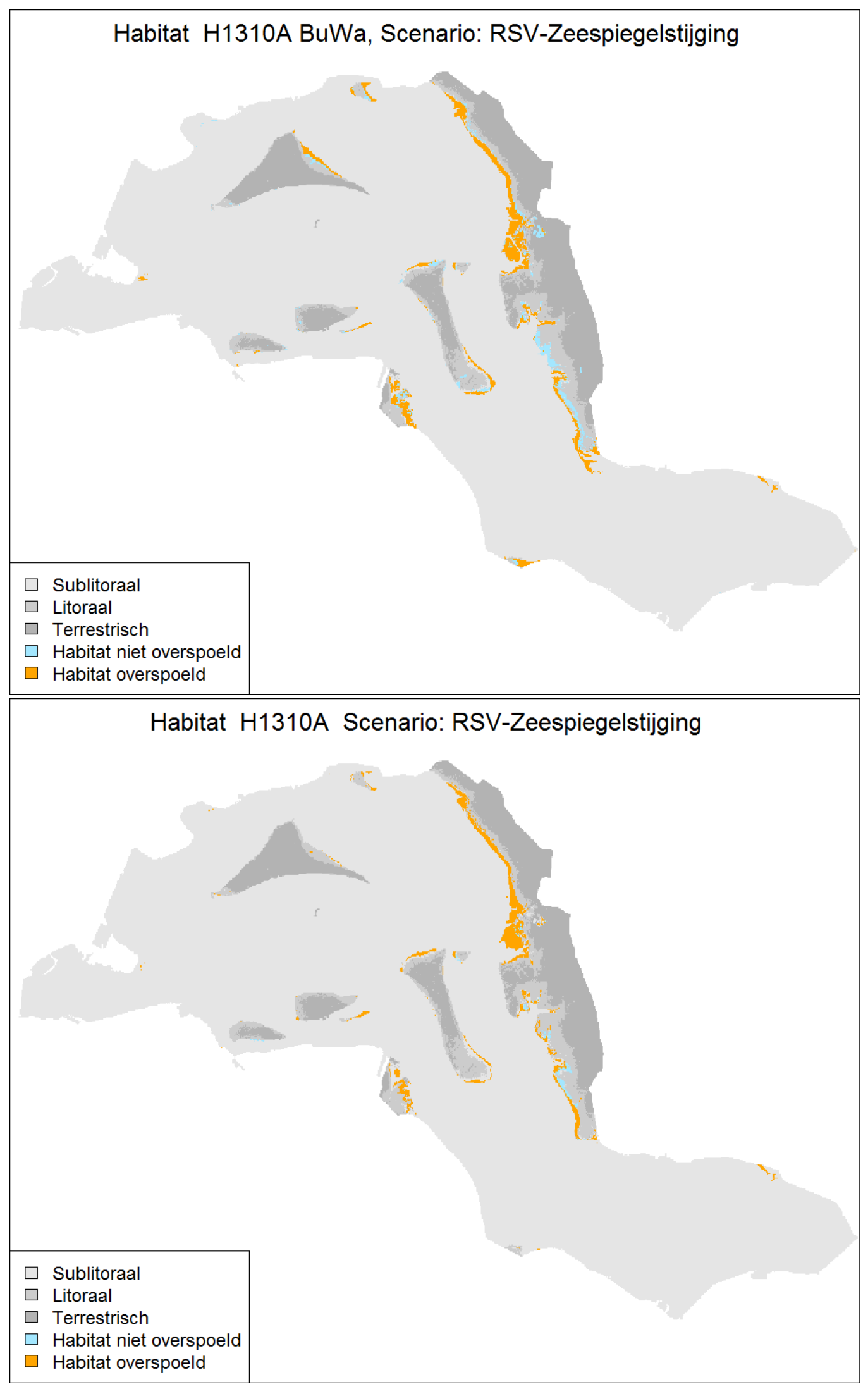



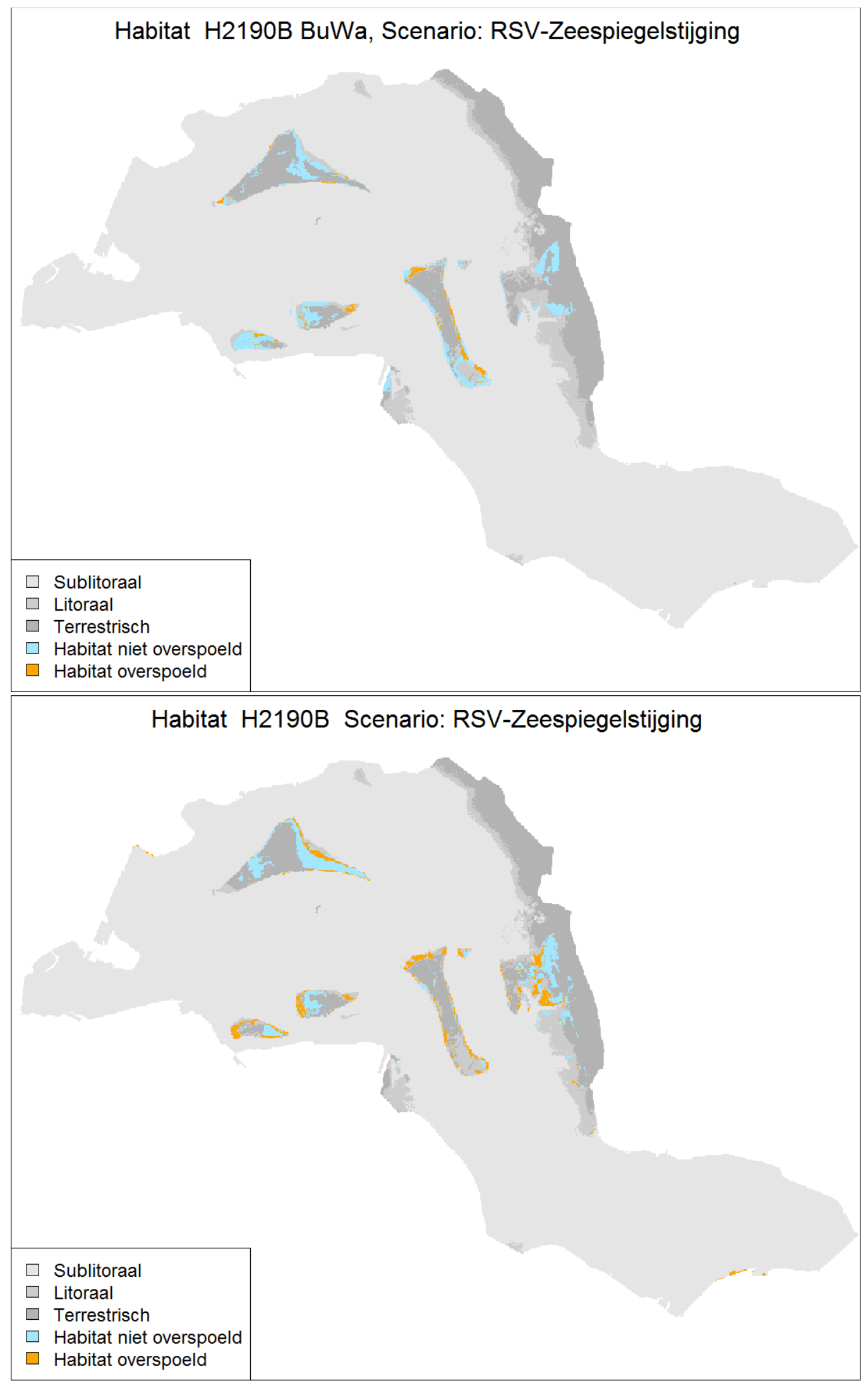

Figuur 50. Huidige ligging van habitattypen H1310A: Zilte pionierbegroeiingen (zeekraal) en H2190B: Vochtige duinvalleien (kalkrijk) in relatie tot het berekende areaal sublitoraal, litoraal en terrestrisch in RSV Zeespiegelstijging scenario. Blauwe tinten blijven behouden, oranje tinten overspoelen. De bovenste kaarten zijn gebaseerd op de habitatkaart van Bureau Waardenburg (2013) "BuWa" en de onderste kaarten zijn gebaseerd op de habitatkaart van Alterra Wageningen UR (2011). 


\section{O. Gemeten oeverprofielen (RWS data) vs geïnterpoleerde oeverprofielen (deze studie)}

Figuur 51. De figuren geven een vergelijking weer van de geïnterpoleerde hoogte van bepaalde oevers in het Grevelingenmeer (rode lijn, deze studie) in vergelijking met hoogten die gemeten zijn op verschillende transecten in 2001 en 2017 (zwarte lijnen) die door Rijkswaterstaat zijn aangeleverd aan Wageningen Marine Research in de afrondende fase van deze studie.
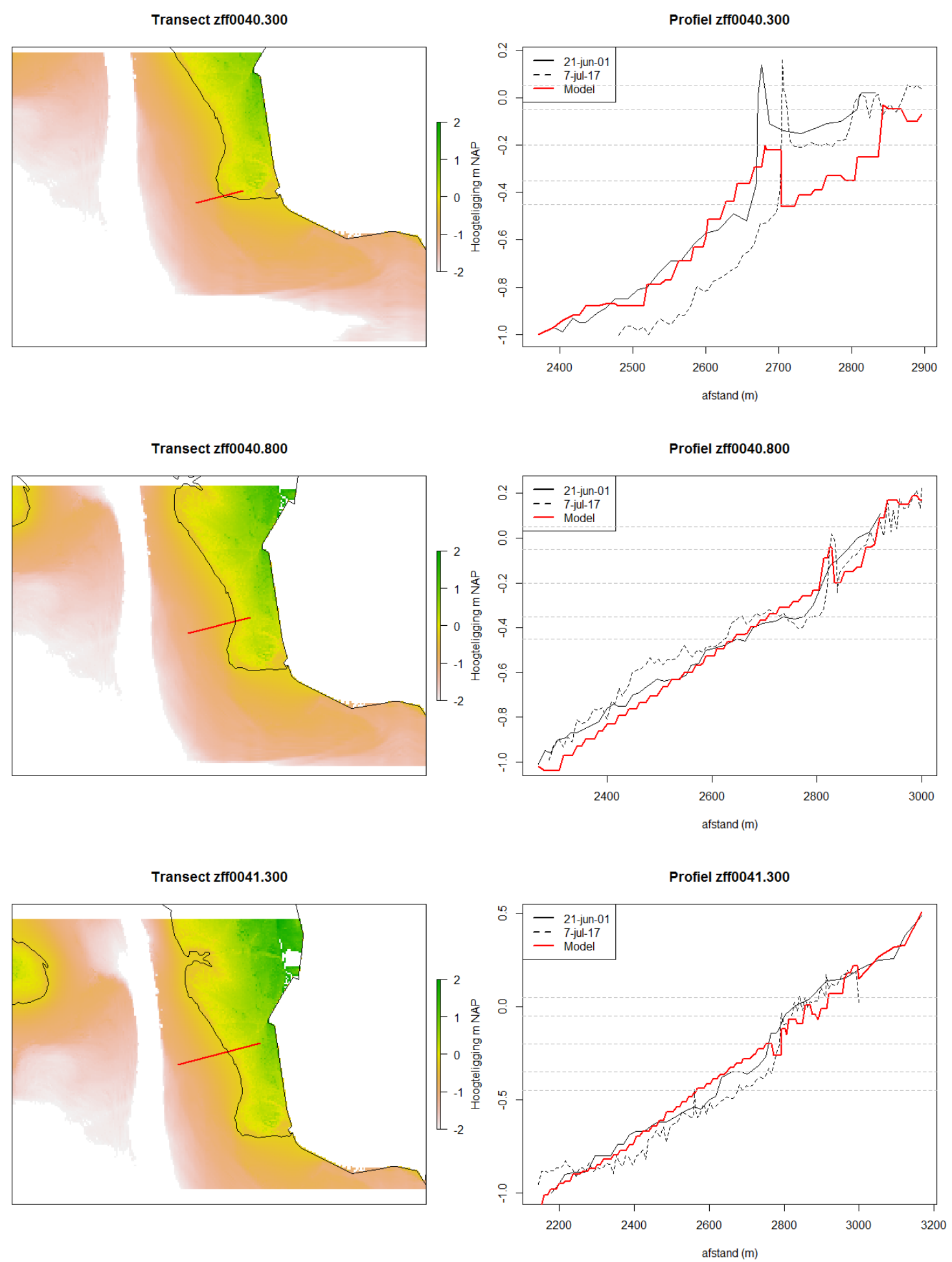

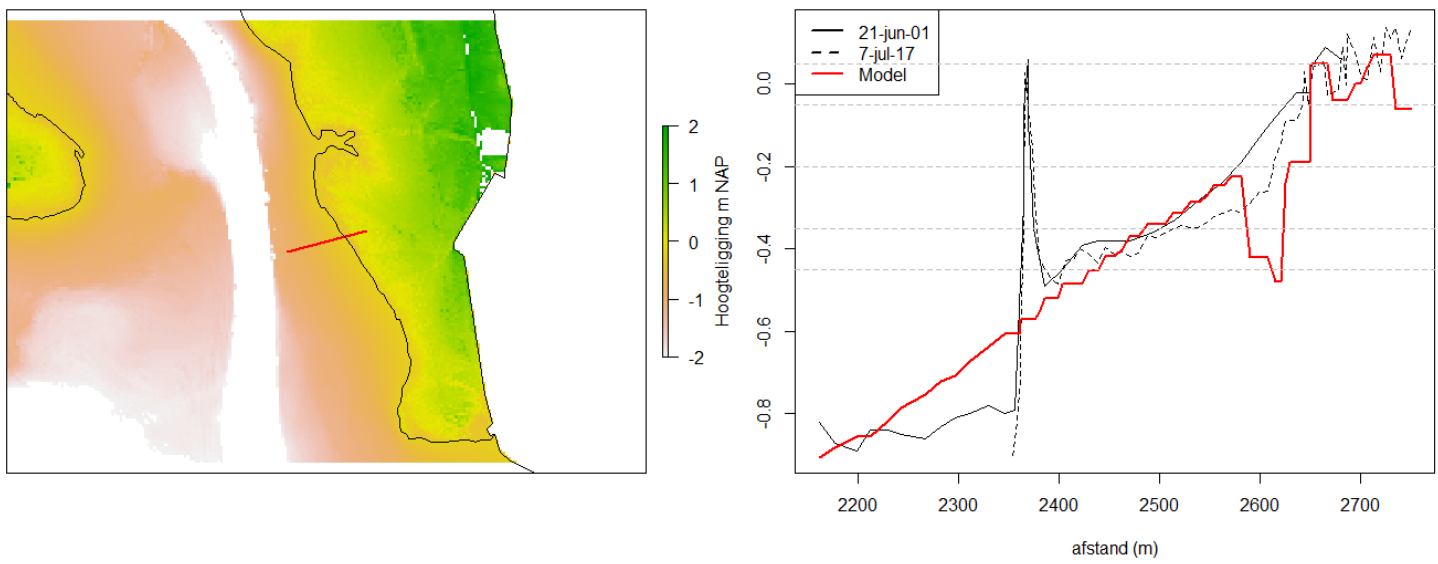

Transect zff0042.300

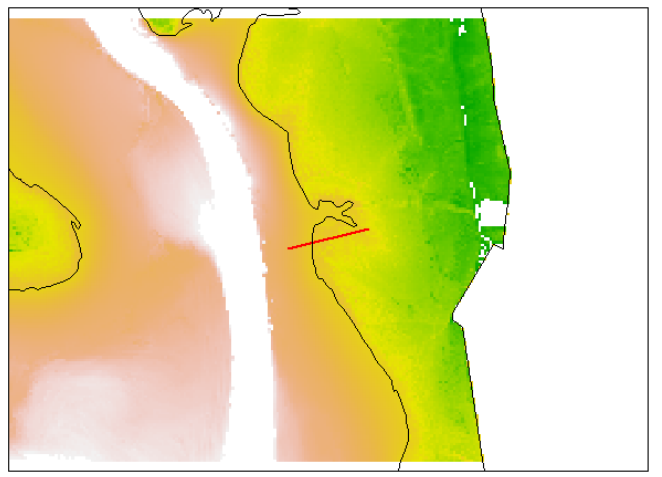

Profiel zff0042.300

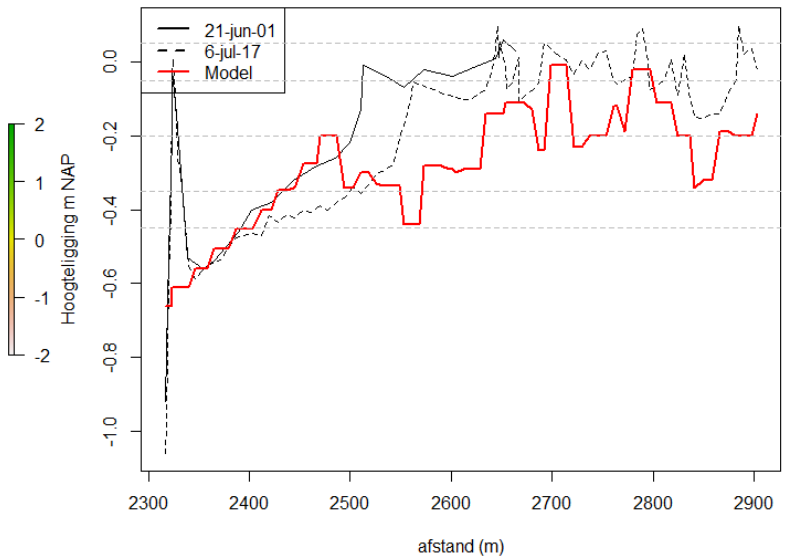

Transect zff0042.800

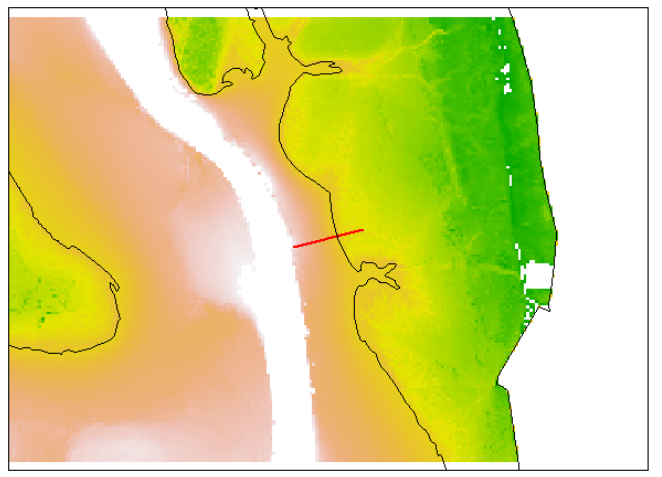

Profiel zff0042.800

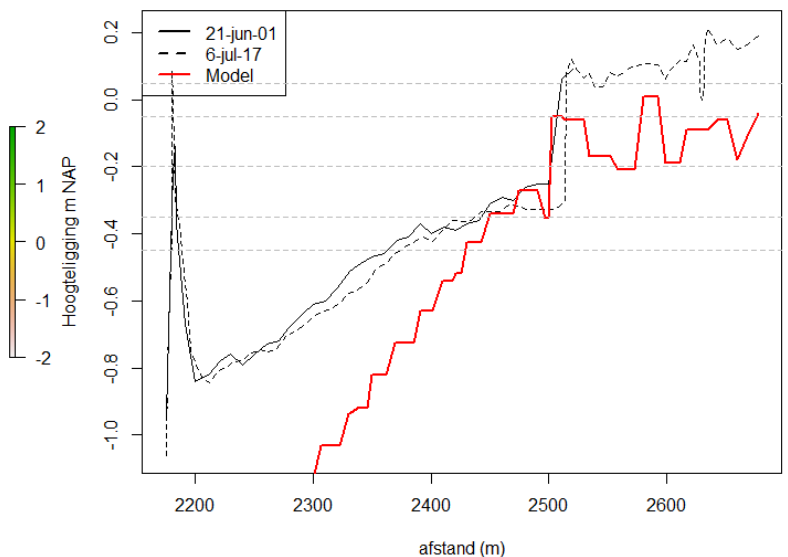


Transect zff0043.300

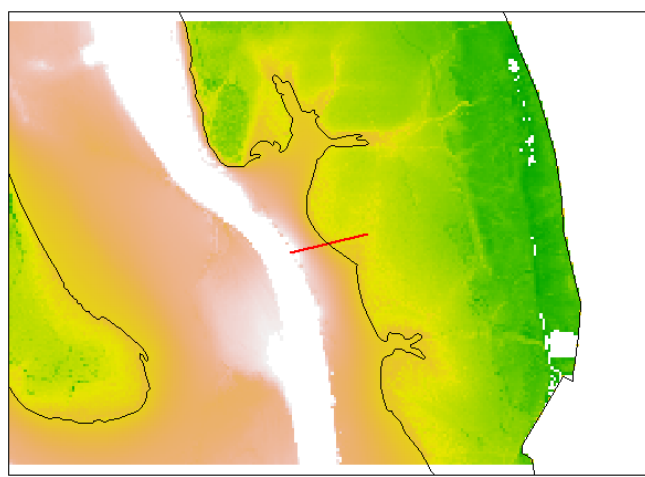

Transect zff0043.800

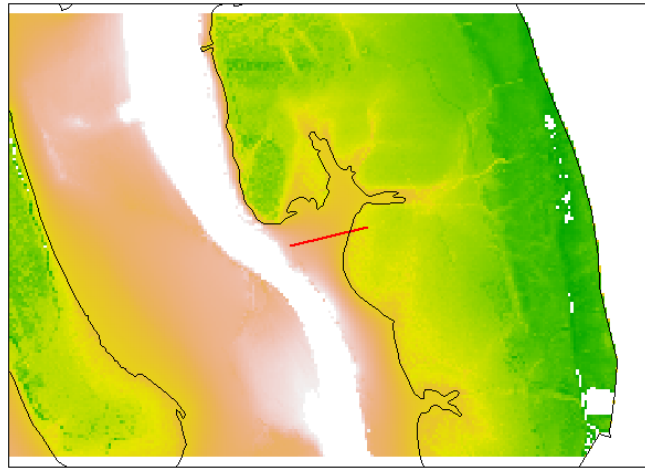

Transect zff0044.300

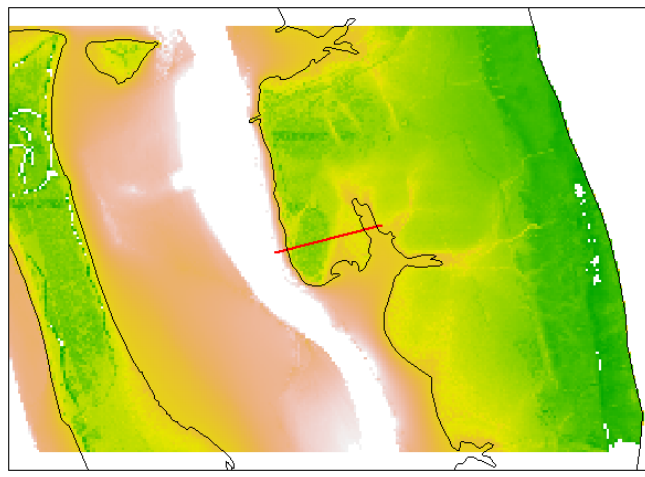

Profiel zff0043.300

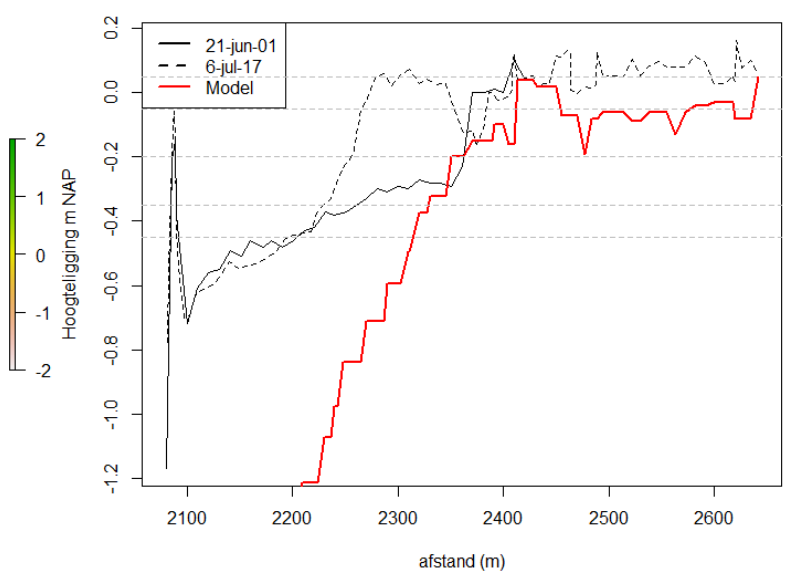

Profiel zff0043.800

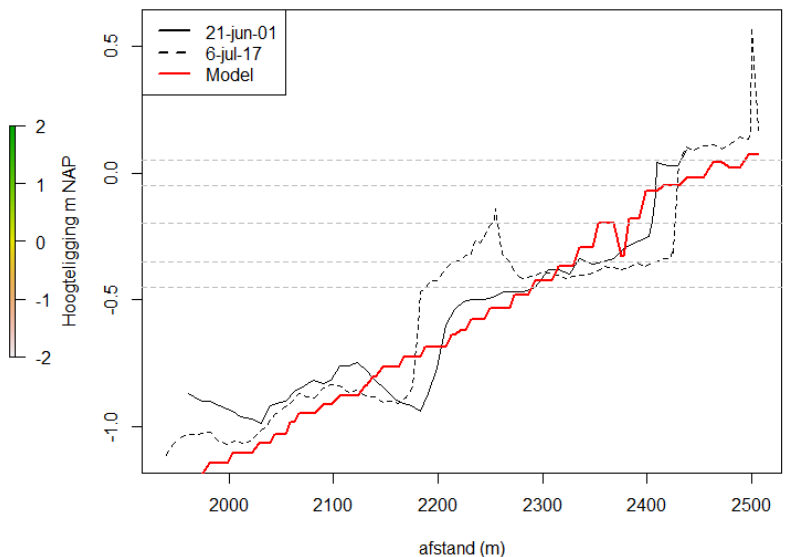

Profiel zff0044.300

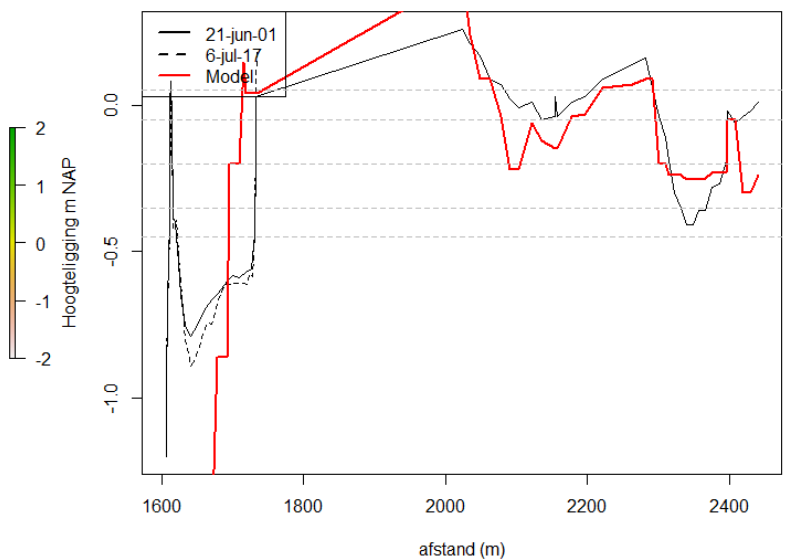



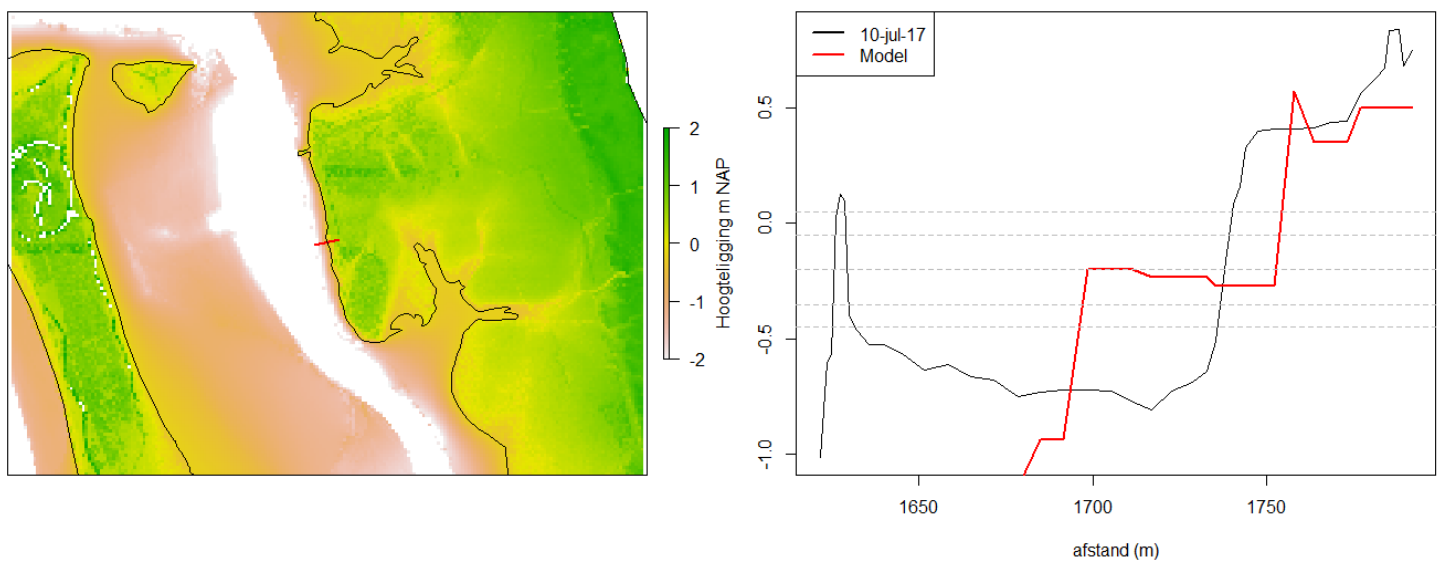

Transect zff0044.725

Profiel zff0044.725
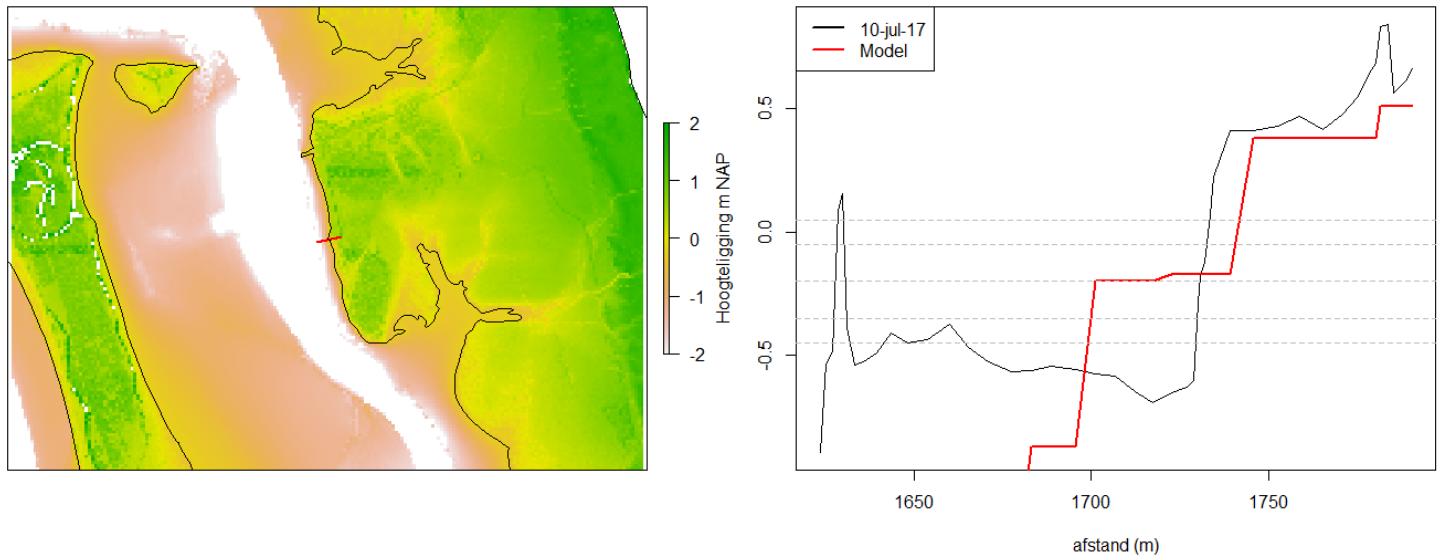

Transect zff0044.750

Profiel zff0044.750
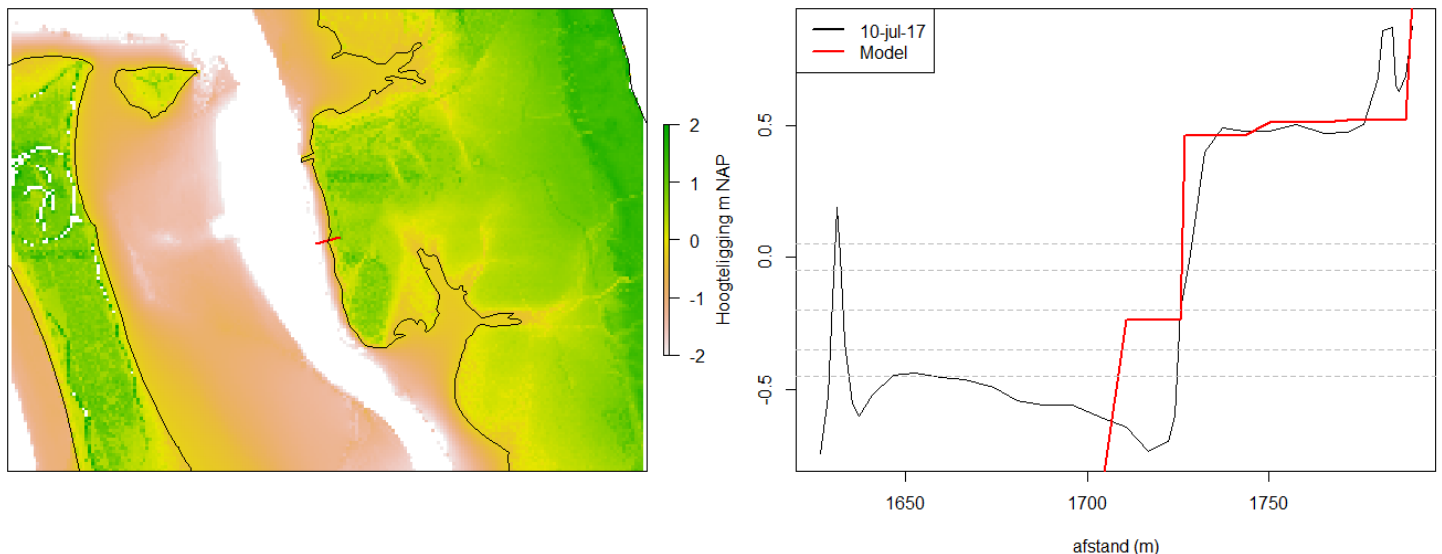

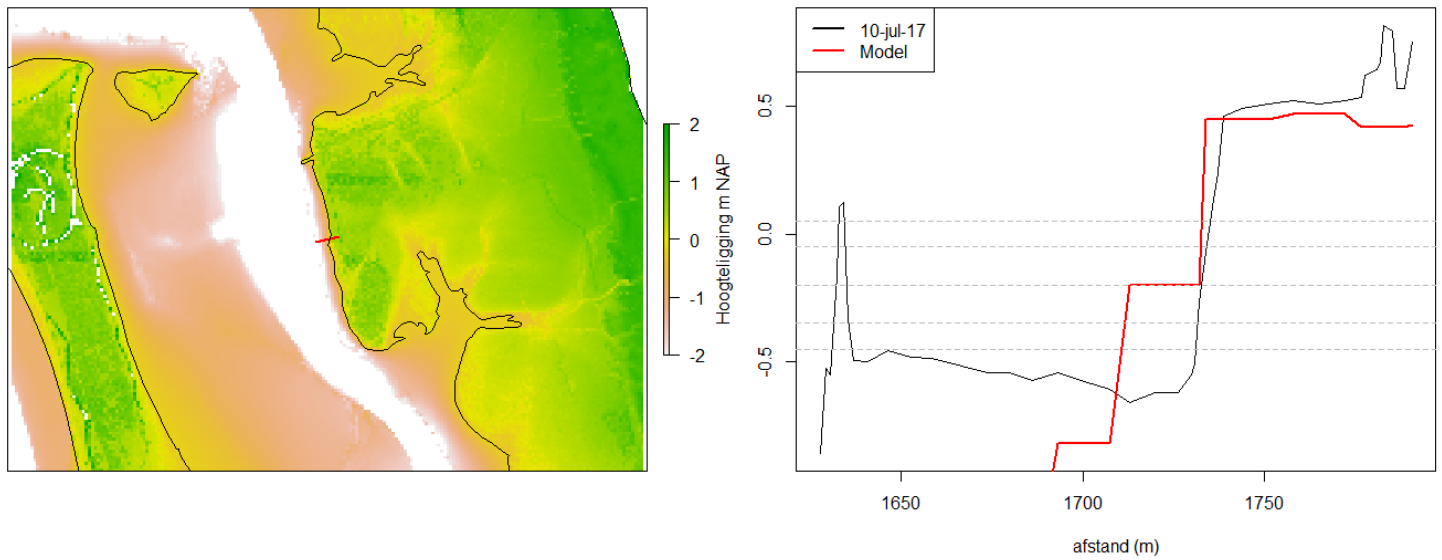

Transect zff0044.800

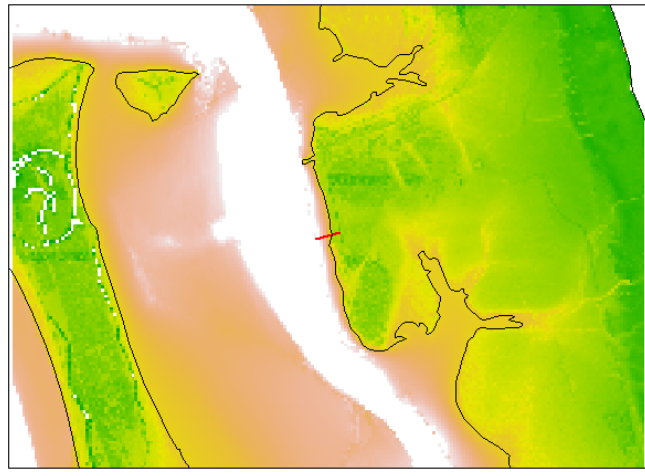

Profiel zff0044.800

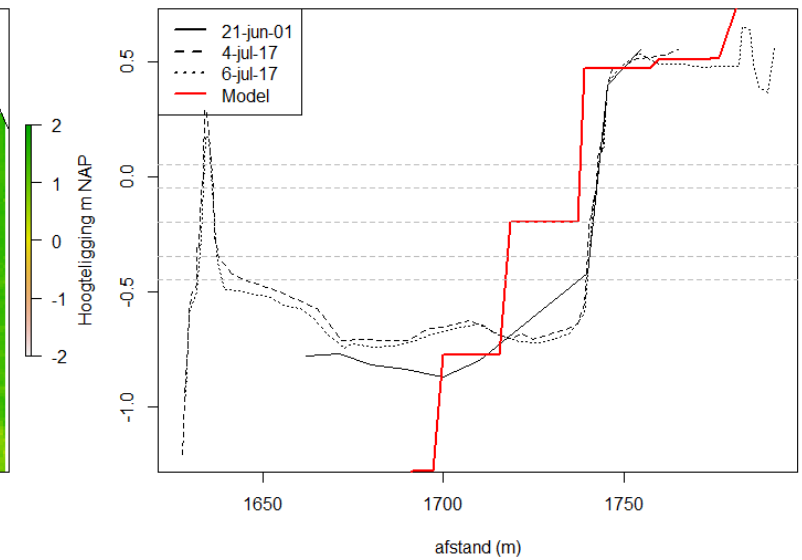

Transect zff0044.825

Profiel zff0044.825
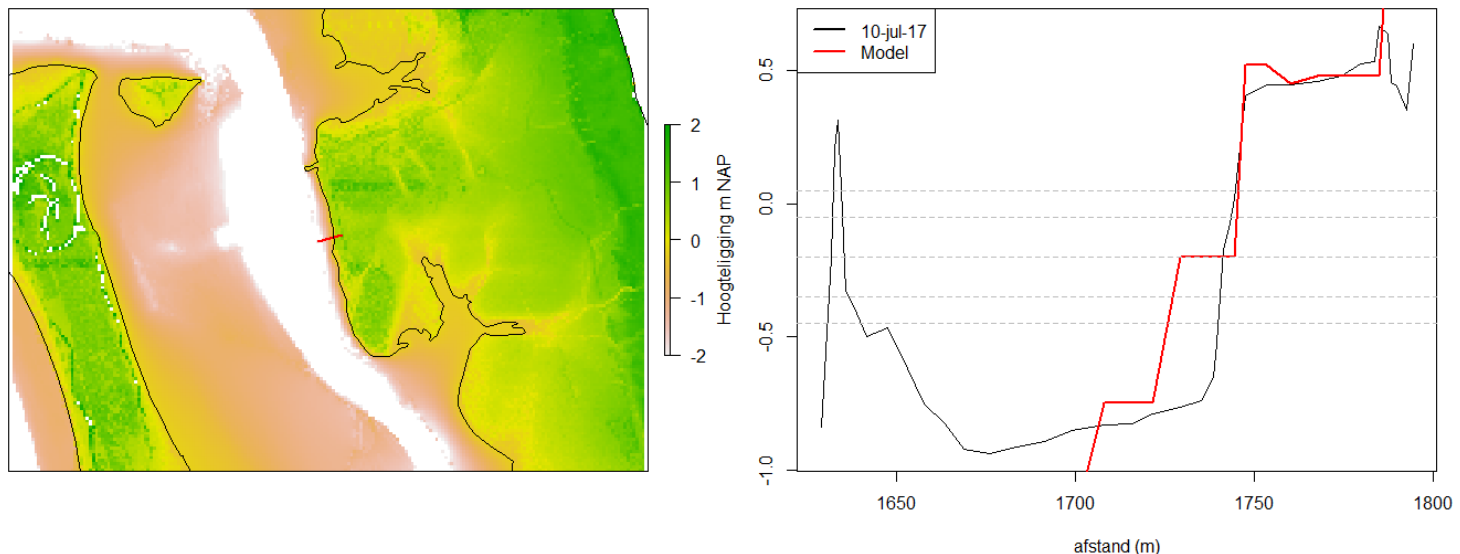

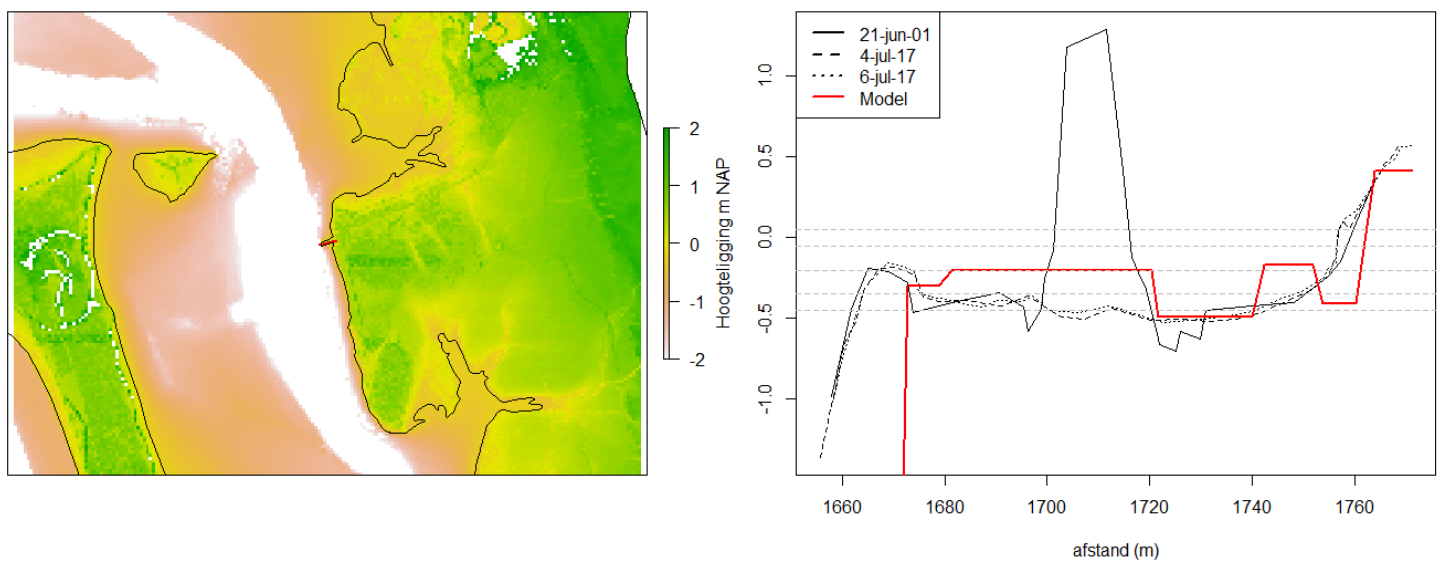

Transect zff0046.000

Profiel zff0046.000
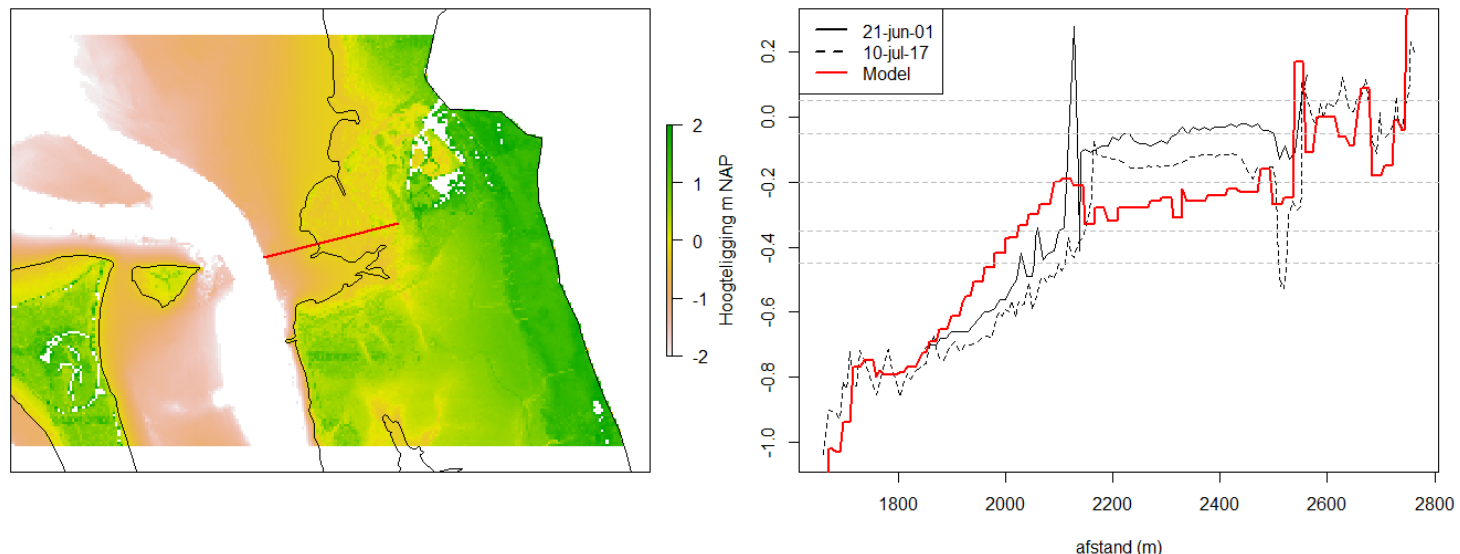

Transect zff0046.500
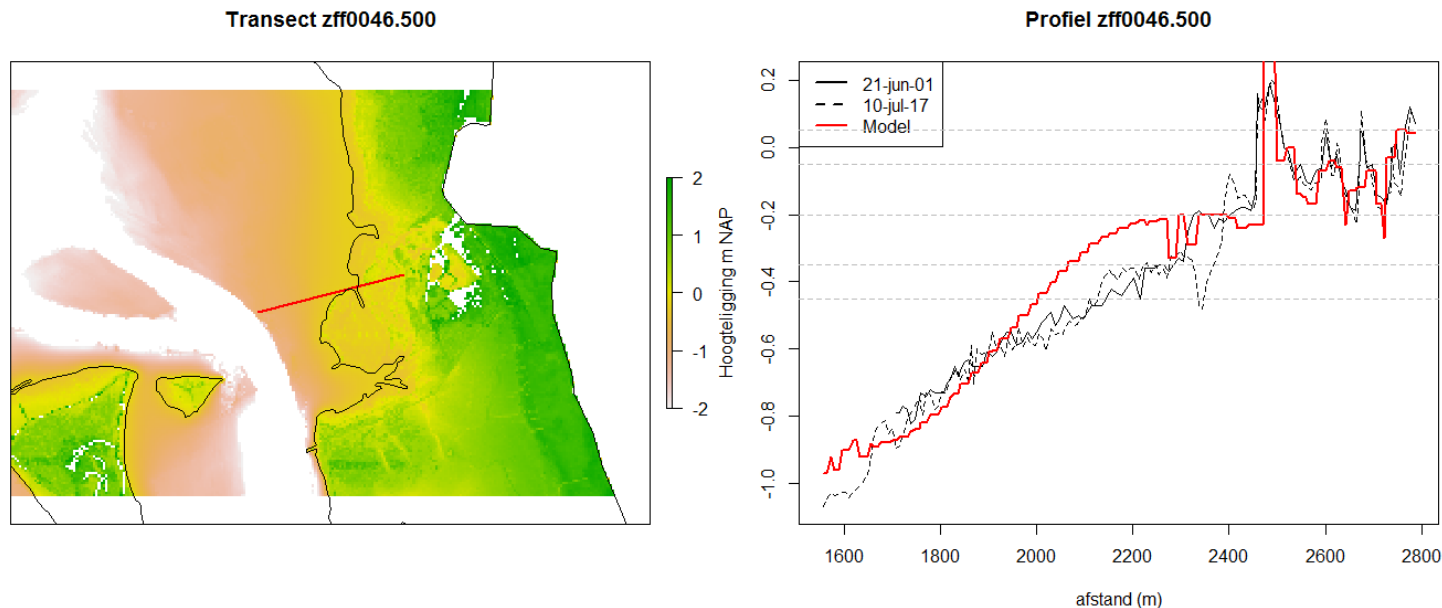

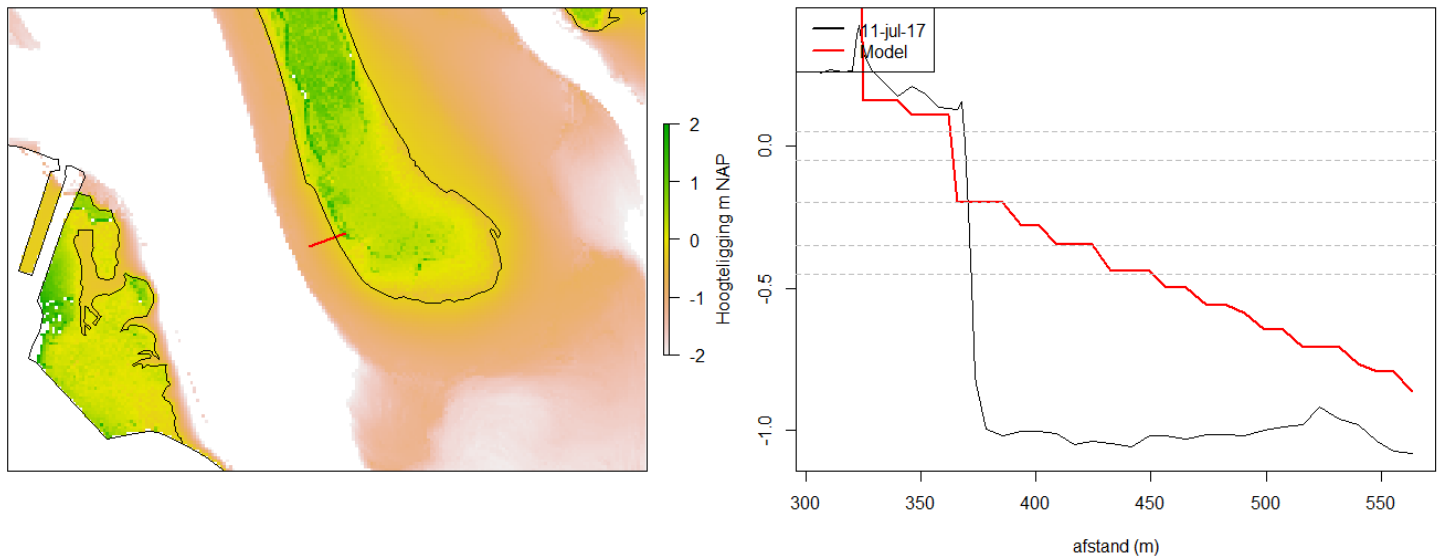

Transect zzI0000.300
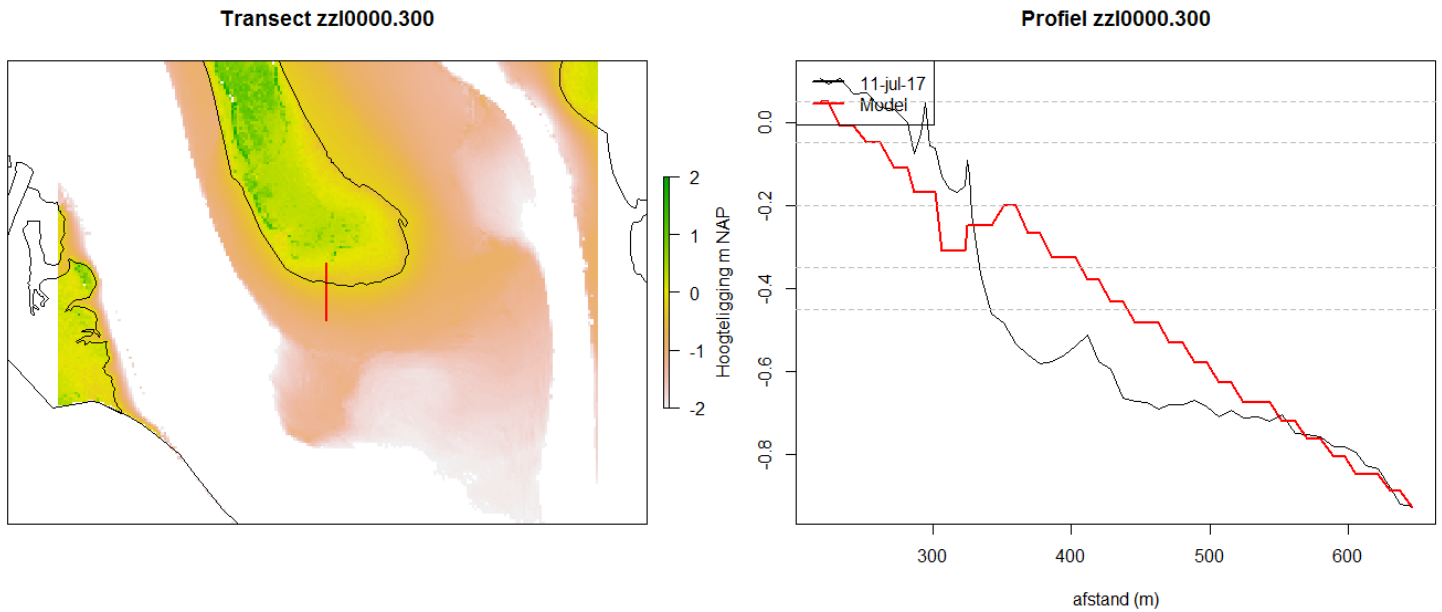

Transect zz|0000.700
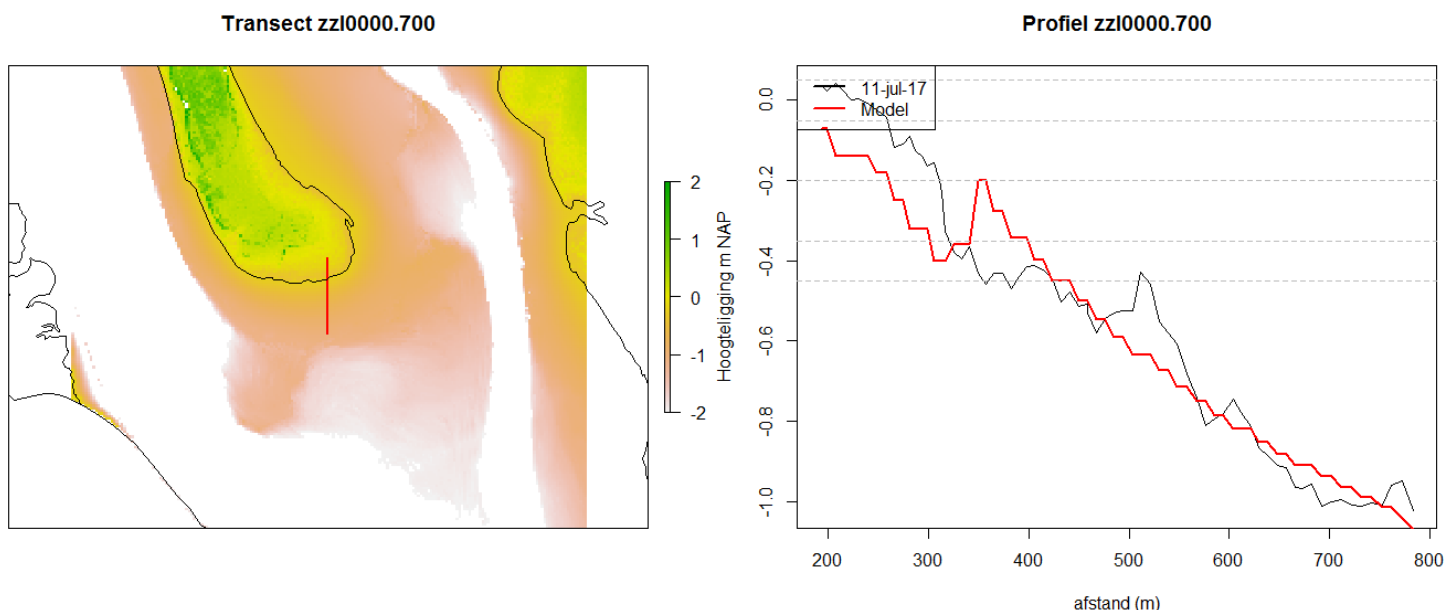

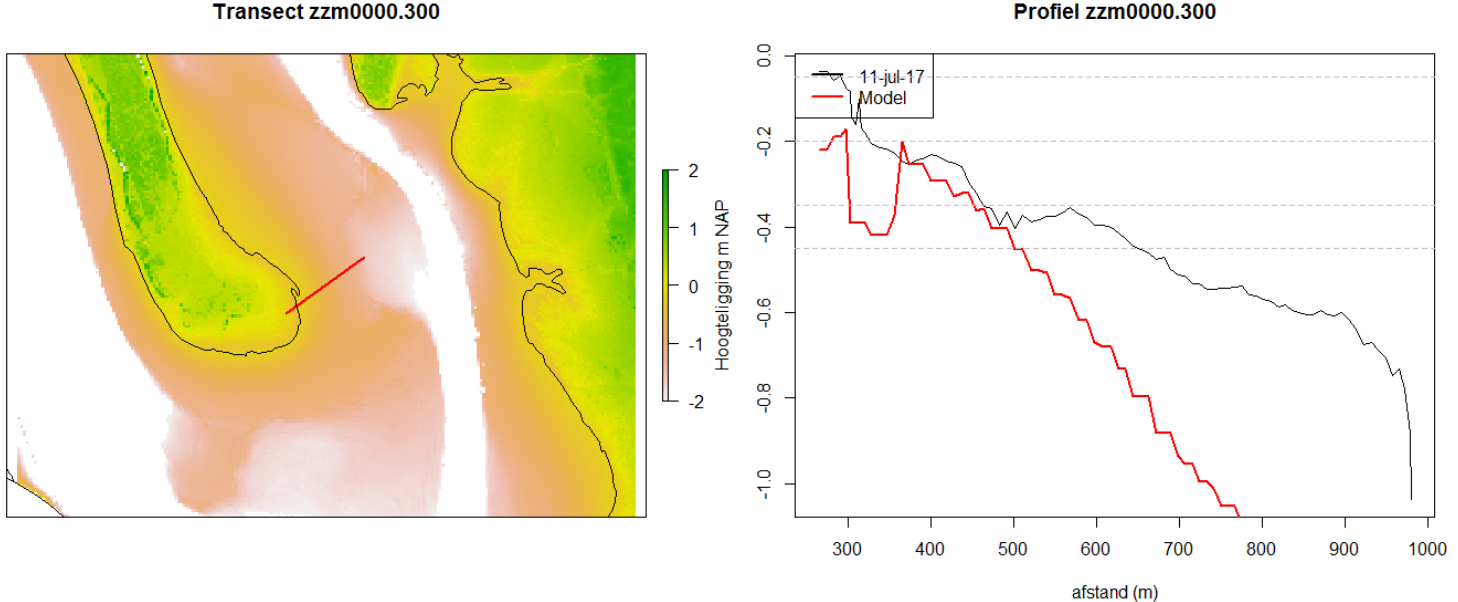

Transect zzm0001.300
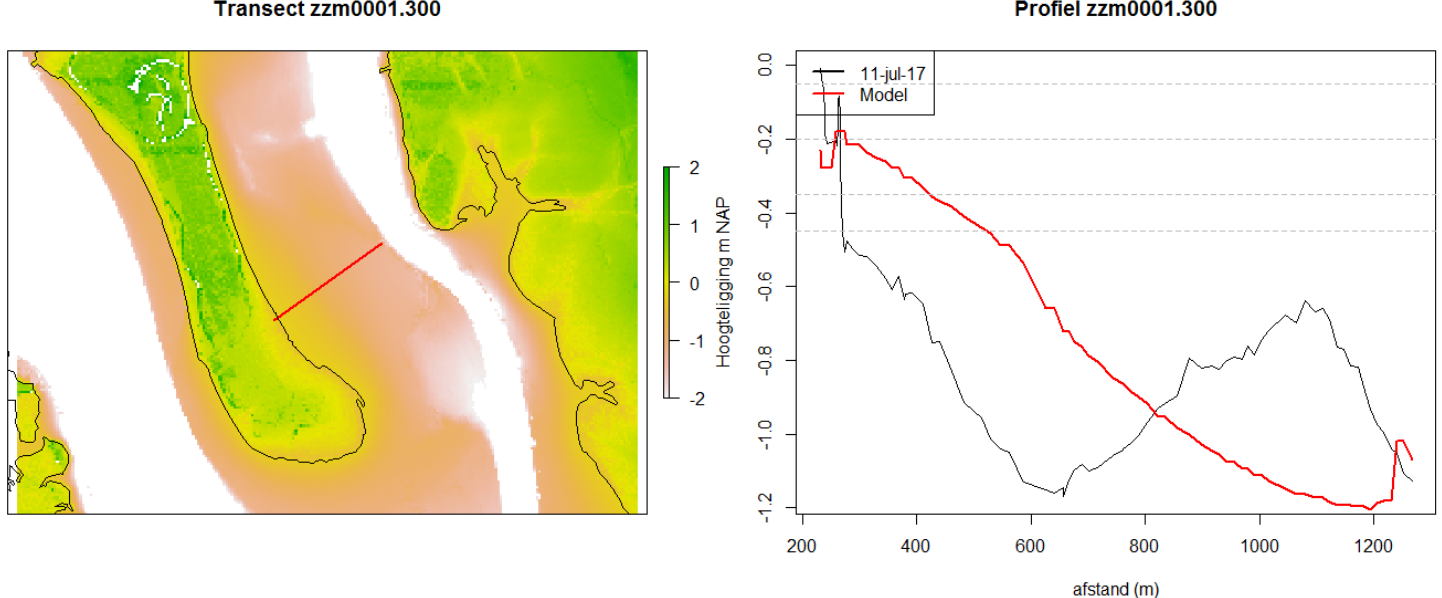

Transect zzn0000.300

Profiel zzn0000.300
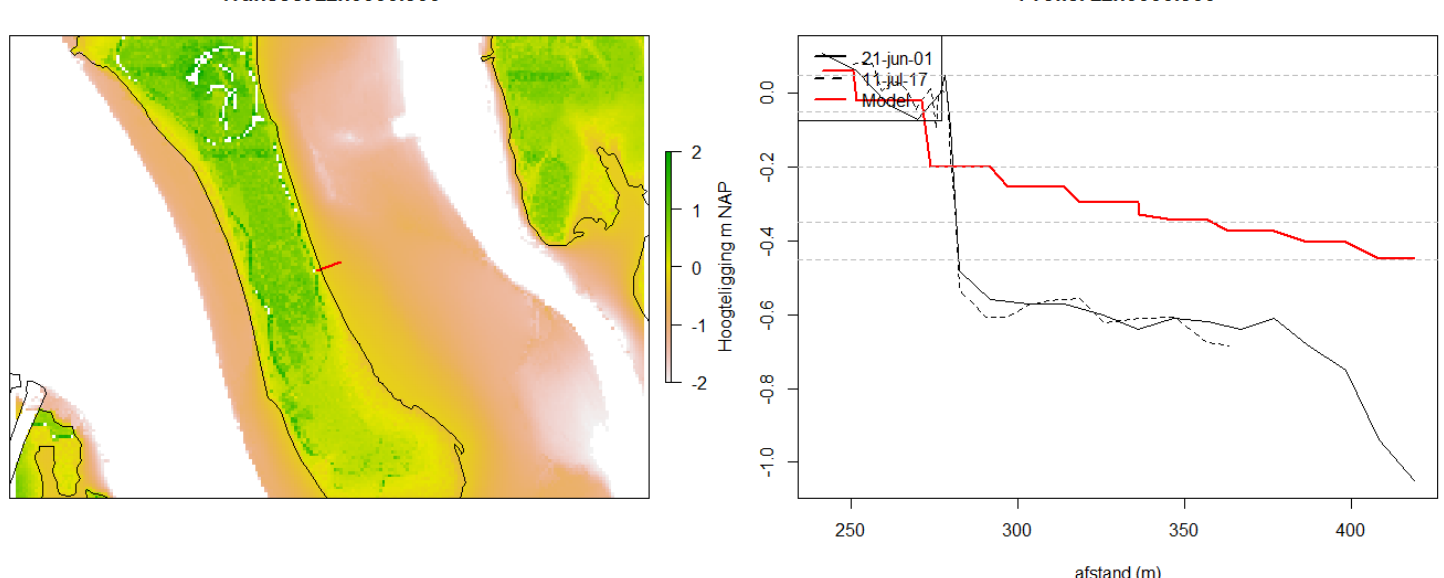

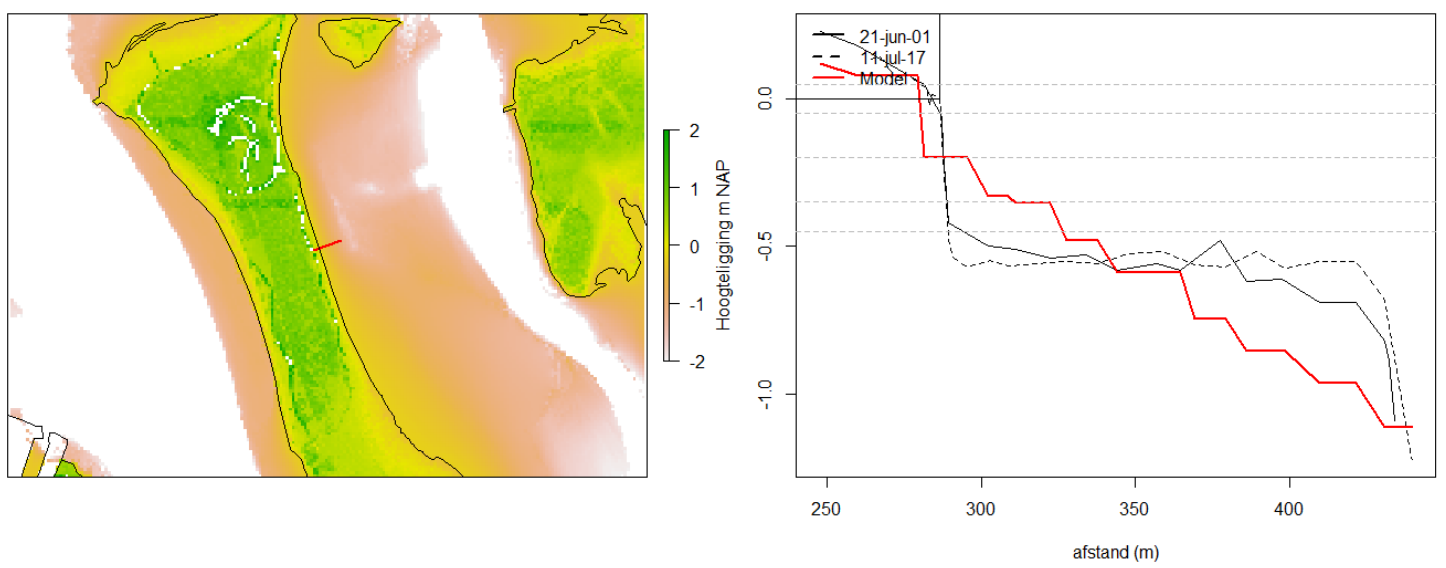

Transect zzo0000.300

Profiel zzo0000.300
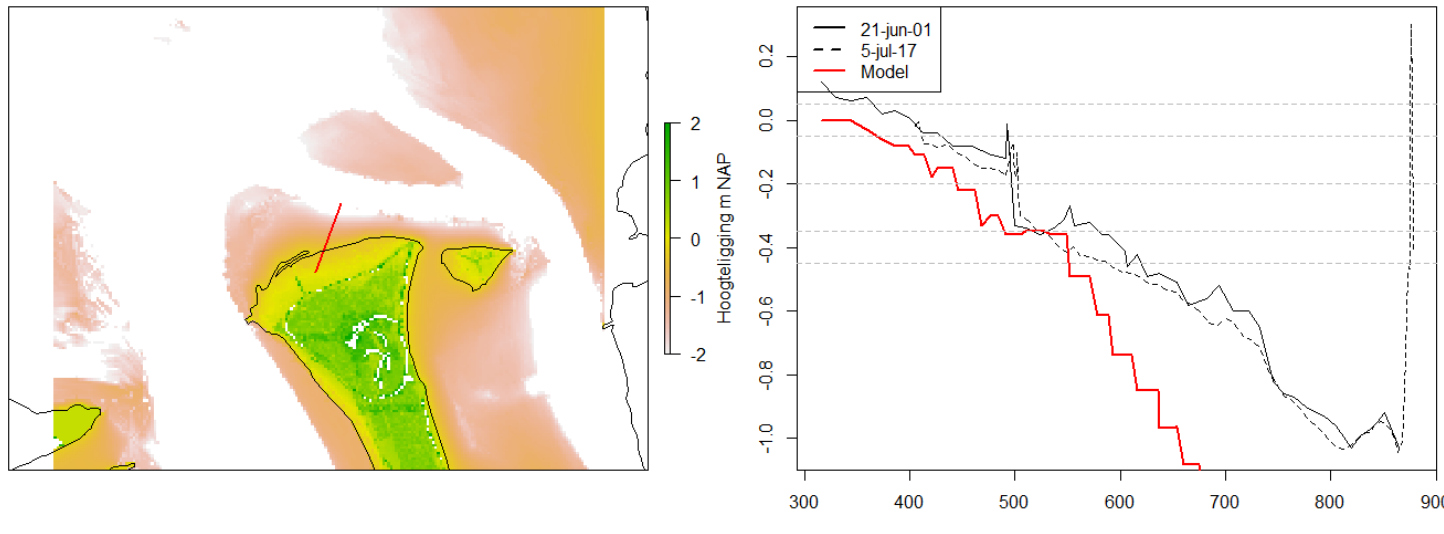

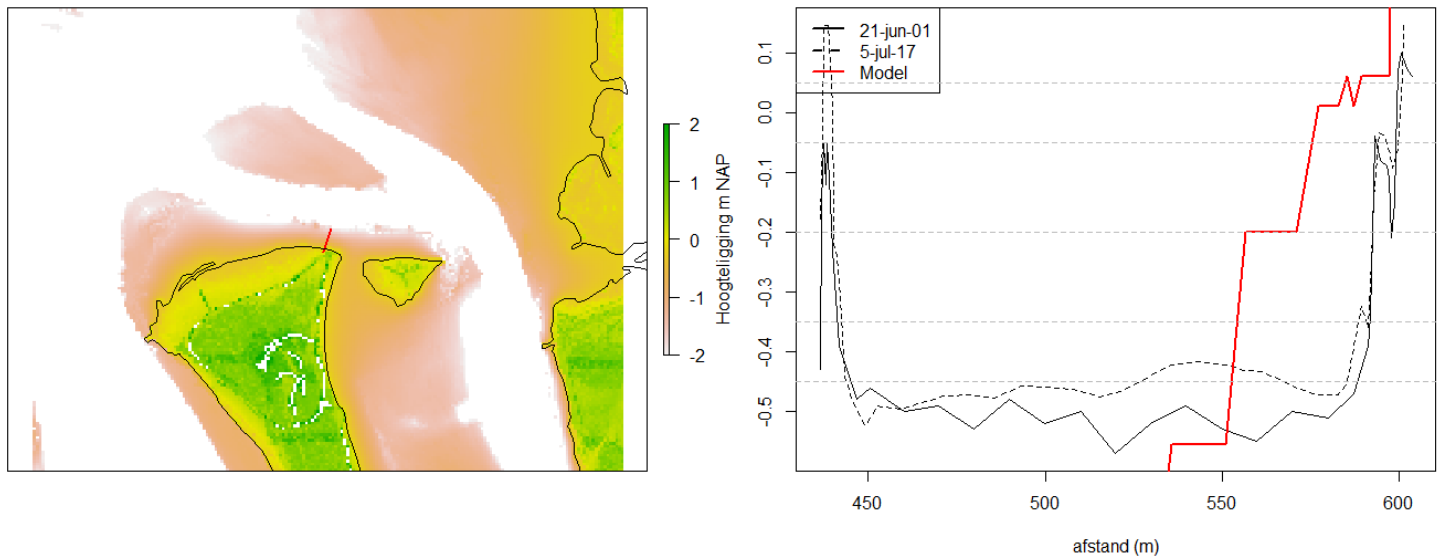

Transect zzs0000.600

Profiel zzs0000.600
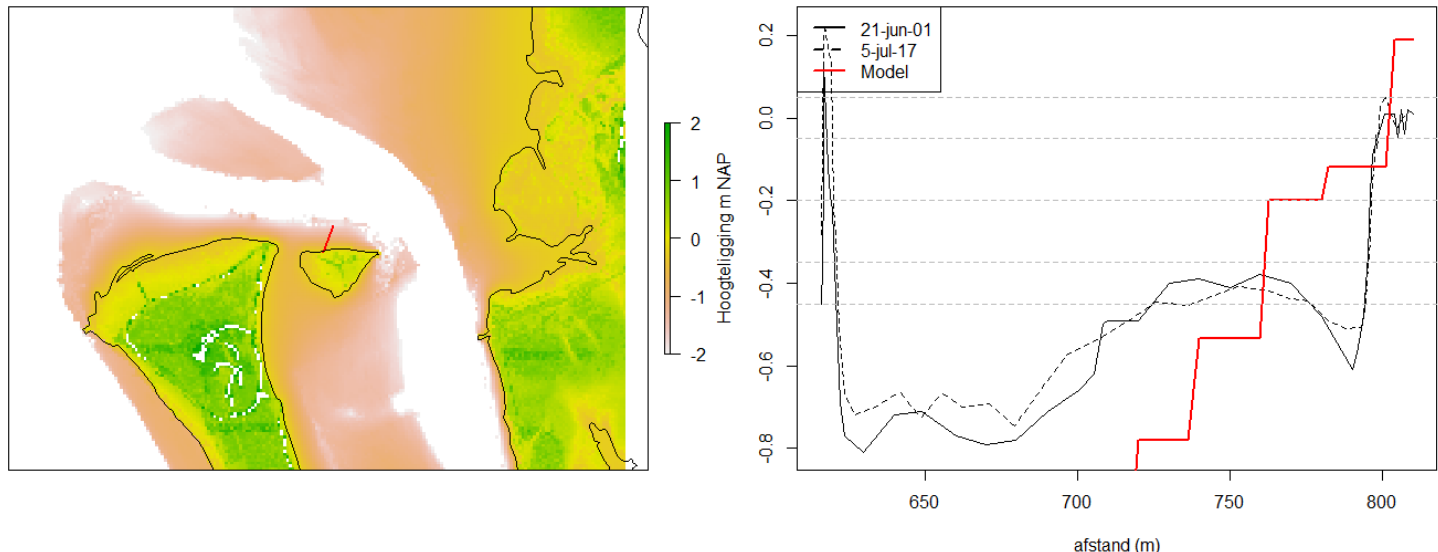
Wageningen Marine Research

T: +31(0)317480900

E: marine-research@wur.nl

www.wur.nl/marine-research

Visitors address

- Ankerpark 271781 AG Den Helder

- Korringaweg 7, 4401 NT Yerseke

- Haringkade 1, 1976 CP IJmuiden
Wageningen Marine Research is the Netherlands research institute established to provide the scientific support that is essential for developing policies and innovation in respect of the marine environment, fishery activities, aquaculture and the maritime sector.

Wageningen University \& Research is specialised in the domain of healthy food and living environment.

\section{The Wageningen Marine Research vision:}

'To explore the potential of marine nature to improve the quality of life.'

\section{The Wageningen Marine Research mission}

- To conduct research with the aim of acquiring knowledge and offering advice on the sustainable management and use of marine and coastal areas.

- Wageningen Marine Research is an independent, leading scientific research institute.

Wageningen Marine Research is part of the international knowledge organisation Wageningen UR (University \& Research centre). Within Wageningen UR, nine specialised research institutes of Stichting Wageningen Research (a Foundation) have joined forces with Wageningen University to help answer the most important questions in the domain of healthy food and living environment. 
